THE ILLINOIAN AND POST-ILLINOIAN PLEISTOCENE GEOLOGY OF IOWA

\author{
by
}

GEORGE F. KAY AND JACK B. GRAHAM 


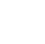

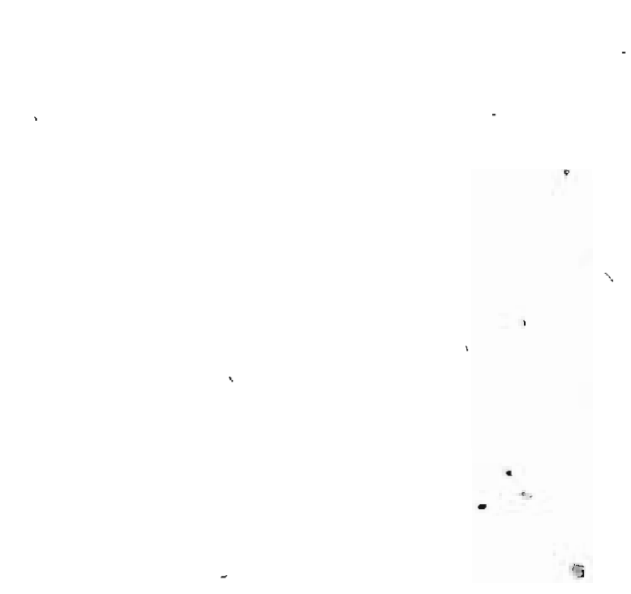




\section{CONTENTS}

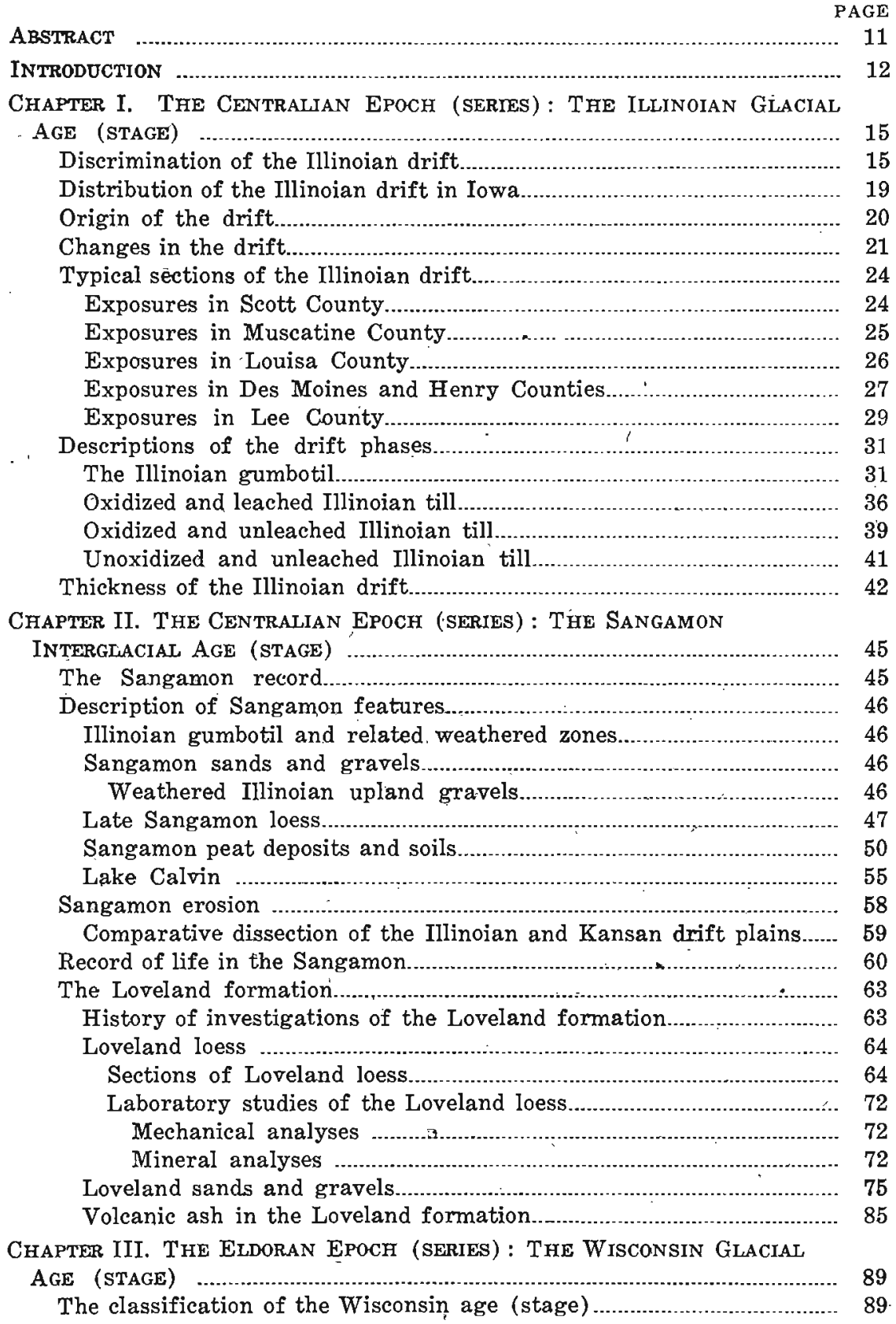


Discrimination of the Iowan drif

Distribution of the Iowan drift in Iowa

Origin of the Iowan drift...................................................................... 105

Changes in the Iowan drift..................................................................... 107

Typical sections of the Iowan drift

Iowan drift in northeastern Iowa....................................................

Iowan drift in northwestern Iowa....................................................... 117

Descriptions of the drift phases........................................................... 125

Iowan boulders ................................................................................... 125

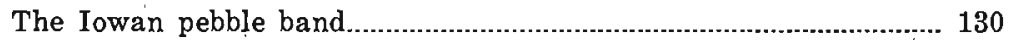

Oxidized and leached Iowan till

Oxidized and unleached Iowan till.................................................... 138

Unoxidized and unleached Iowan till .......................................... 139

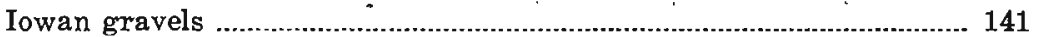

The Iowan upland gravel

The Iowan terrace gravel................................................................. 147

Thickness of the Iowan drift............................................................. 153

The Peorian intraglacial subage (substage) .......................................... 155

Classification of the Peorian intraglacial subage (substage) ............ 156

The Peorian loess........................................................................................ 157

Distribution and topographic expression of the Peorian loess

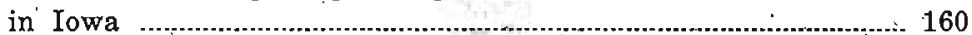

Loess mantled erosional topography

The Crawford area

The Cedar and Jackson areas................................................. 163

Loess depositional topography........................................................ 164

Typical sections of the Peorian loess in Iowa..................................... 165

Characteristics of the Peorian loess............................................ 172

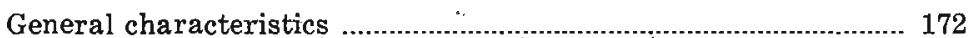

Mechanical analyses ................................................................... 173

Mineral analyses ............................................................................ 183

Chemical analyses ........................................................................ 184

Fossils of the Peorian loess.............................................................. 186

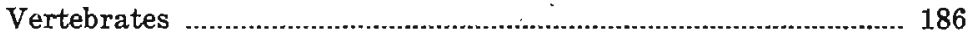

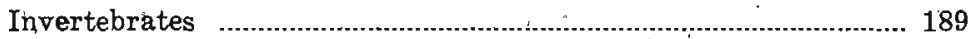

Depth of leaching in the Peorian loess........................................... 195

Thickness of the Peorian loess in Iowa.......................................... 196

Comparison of the Peorian loess with the Loveland loess................... 198

The Mankato glacial subage (substage) .................................................. 203

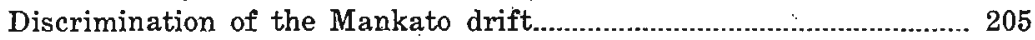

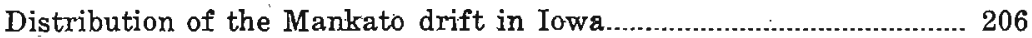

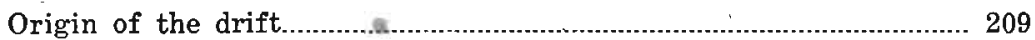

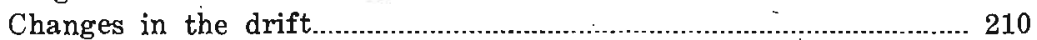

Typical sections of the Mankato drift..................................................... 211

Mankato till over loess and pre-Iowan till...................................... 211

Mankato till over Peorian loess......................................................... 216

Exposures showing only Mankato till or gravel.............................. 217 
PAGE

Descriptions of the drift phases.................................................... 220

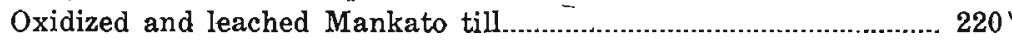

Oxidized and unleached Mankato till........................................... 221

Unoxidized and unleached Mankato till.............................................. 223

The Mankato gravels.................................................................................. 224

The Mankato, upland gravel............................................................... 224

The Mankato terrace gravel..................................................... 230

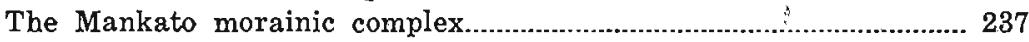

Thickness of the Mankato drift...................................................... 242

Chapter IV. The Eldoran Epoch (series): The Recent Interglacial

AGE (STAGE) ............................................................................... 244

The record of the Recent......................................................................... 245

Descriptions of Recent features....................................................... 246

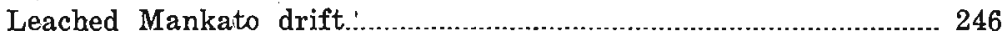

Peat on the Mankato drift.............................................................. 246

Duration of the Recent.............................................................................. 248

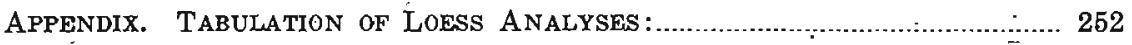

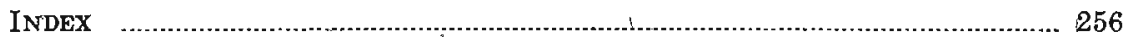




\section{ILLUSTRATIONS}

FIGURE -PAGE

1. Map showing the surface distribution of the drift sheets and other glacial features of Iowa........................................................................... 16

2. Map of Iowa showing the extent of Illinoian glaciation in the state... 18

3. Diagram of a complete normal section of Illinoian till.......................... 22

4. Exposure showing dark soil, Peorian loess, and Loveland loess. Brick and Tile Plant, Mediapolis, Des Moines County.

5. Graphs showing mechanical analyses of Illinoian gumbotil from six different localities

6. Graphs showing average mechanical analyses of the several tills

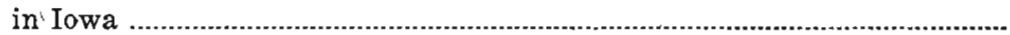

7. Graphs showing average shape analyses of Illinoian gumbotil and unoxidized and unleached Illinoian till.

8. Map of eastern Iowa showing locations of some exposures of Illinoian and Kansan gumbotils.

9. Graphs showing (a.), mechanical analysis and (b), lithological analysis of Illinoian upland gravel.

10. Diagram showing the stratigraphic relationships of Loveland loess in eastern Iowa.

11. Graph showing pollen percentages in a Sangamon peat bed. (After Geo. H. Lane)

12. Sketch map of the Lake Calvin area showing the location and extent of the lake. The small squares show the location of exposures described by Schoewe. (Map by Schoewe)

13. Diagram showing the Loveland loess relationships eastward from the type area in Iowa.

14. Layer of concretions in the Loveland loess exposed in the valley, bluffs near Council Bluffs.

15. Section showing Loveland loess, Iowan till and Peorian loess. O'Brien County

16. Loveland loess in section in Cass Township, Shelby County..

17. Section in Fayette County, showing Loveland loess below Iowan till 70

18. Map showing locations of Loveland loess samples used in compiling average analyses

19. Graph showing mechanical analysis of average of 35 samples of Loveland loess

20. Diagram illustrating similarity of minor mineral percentages in Kansan till and Loveland loess..

21. Map showing locations of Loveland sand and gravel exposures in Iowa

22. Map showing locations of "undifferentiated terrace gravel" exposures in Iowa

23. Graphs showing mechanical analyses of Loveland gravel. The numbers of this figure correspond with those of figure 24 . 
FIGURE

24. Graphs showing lithology of pebbles between 16 and 32 millimeters in diameter. The numbers of these analyses correspond to those of figure 23 .

25. (a) Volcanic ash in the Loveland formation, Harrison County. (b) Graph showing mechanical analysis of the ash. (After A. C. Tester) 86

26. Map of Iowa showing the extent of Iowan glaciation in the state....... 100

27. Map of Iowa showing by patterns the main areas of distinctive topographic development in the state.

28. Map of Iowa showing by diagram the depths of leaching of calcium carbonate in materials within the Iowan and Mankato drift areas of

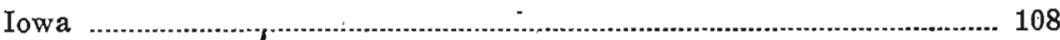

29. Iowan drift overlying distinctive Buchanan gravels near Doris, Buchanan County

30. Map of Iowa showing the locations of large granitic boulders in and adjacent to the Iowan drift area. (Modified. from Alden and Leighton, 1915)

31. Field of Iowan boulders south of Bassett, Chickasaw County............. 127

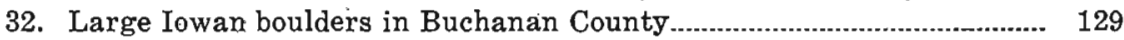

33. Large Iowan boulder in Chickasaw County ................................................ 129

34. Iowan boulder in Grundy County measuring 32 by 28 feet with an exposed height of 10 feet.

35. Pebble band with Iowan till below and Peorian loess above, Fremont Township, Cedar County.

36. Wind polish on boulder from pebble band, Fremont Township, Cedar County

37. Pebble band on Iowan till just west of Denver Junction, Bremer County 133

38. Map of Iowa showing the locations of Iowan upland gravels................. 140

39. Graphs showing the mechanical analyses of Iowan upland gravels....... 143

40. Graphs showing the lithological analyses of Iowan upland gravels within the size range 16 to 32 millimeters in diameter ............................ 144

41. Map of Iowa showing the locations of Iowan terrace gravel exposures 146

42. Terrace gravel of Iowan age near Iowa City, Johnson County............. 148

43. Graphs showing mechanical analyses of Iowan terrace gravel.............. 149

44. Graphs showing the lithological analyses of Iowan terrace gravel within the size range 16 to 32 millimeters in diameter.

45. Divide cut between Aspinwall and Manilla, Crawford County, showing about 25 feet of. Peorian loess overlying Kansan drift.

46. Looking north along loess bluffs from top of ridge south of Pisgah, Harrison County

47. Cut showing 90 feet of Peorian loess, near Missouri Valley, Harrison County

48. Airplane view of north-south trending loess ridges on the Iowa side of the Missouri River Valley. (Photo by Des Moines Register-Tribune) 166

49. Loess hill bordering the Iowan drift plain near North Liberty, Johnson County. A 52-foot loess section was obtained here.

50. Graph showing a series of mechanical analyses of a loess section near North Liberty, Johnson County. Samples taken two feet apart vertically 
FIGURE

51. Topographic map of the North Liberty area showing the location of the 52-foot loess section

52. View in the Gaulocher clay pit, Iowa City, Johnson County, showing two phases of loess and effect of plant roots in oxidation and deoxidation

53. Peorian loess overlain by Mankato drift, just west of Panora, Guthrie County

54. Vertical walls in a Peorian loess cut near Magnolia, Harrison County 174

55. Map of Iowa showing traverses followed in collecting Peorian loess samples used in laboratory analyses.

56. Graph showing the series of mechanical analyses of loess samples collected between Sioux City and Spencer.

57. Graph showing the series of mechanical analyses of loess samples collected between Sioux City and Sac City.

58. Graph showing the series of mechanical analyses of loess samples collected between Donnellson and Sidney'.

59. Graph showing the series of mechanical analyses of loess samples collected between Tama and Iowa Falls.

60. Graph showing the series of mechanical analyses of loess samples collected between Missouri Valley and Iowa City...

61. Graphs showing mechanical analyses of Peorian loess collected in northeastern Iowa

62. Graphs showing mechanical analyses of Peorian loess collected in 'northeastern Iowa

63: Graph showing the average mechanical analysis for loess samples collected throughout Iowa............................................................................. 181

'64. Mineralogical analyses of various Pleistocene materials of Iowa........ 182

65. Graphs illustrating the correlation of heavy mineral percentages of Peorian loess, Iowan till, Loveland loess and Kansan till, of Iowa....... 183

66. Graphs showing the chemical analyses of leached Peorian loess.......... 186

67. Terrestrial gastropods of the Peorian loess of Iowa. (After B. Shimek) 191

68. Graph showing the vertical distribution of fossils identified in the loess section near North Liberty, Johnson County. (After Cornelia Cameron)

69. Map of Iowa showing relative thickness of Peorian loess bjy degree of shading

70. Map of Iowa showing by contours the thickness of the Peorian loess. Where the loess is less than 5 feet thick, a number rather than a contour shows the thickness. The contours across the Mankato area represent loess beneath rather than above the Mankato drift............... 199

71. Map of Iowa showing locations of Loveland and Peorian loess samples collected for laboratory analyses. : Squares represen't Loveland locations; circles represent Peorian locations.

72. Graphs showing the mechanical analyses of Loveland and Peorian loesses ....................................................................................................... 201

73. Graph showing the heavy mineralogical analyses of Loveland and Peorian'loesses

74. Stream on the Mankato drift illustrating the immature stage of erosion of the drift, Palo Alto County 
FIGURE

75. Sketch map of Wright County showing peat, muck and lake areas on the Mankato drift plain.

76. Map of Iowa showing the extent of Mankato glaciation. 208

77. Wisconsin till of Mankato age overlying Peorian loess in Chicago, Milwaukee, St. Paul \& Pacific Railway cut southwest of Rhodes, Marshall County.

78. Lithological analysis of leached and unleached Mankato till................... 222

79. Map of Iowa showing locations of Mankato upland gravel deposits.... 225

80. Graphs showing mechanical analyses of Mankato upland gravels........ 226

81. Graphs showing lithological analyses of Mankato upland gravels within the size range 16 to 32 millimeters in diameter.

82. Map of Iowa showing locations of Mankato terrace gravel deposits..... 232

83. Graphs showing mechanical analyses of Mankato terrace gravels........ 234

84. Graphs showing lithological analyses of Mankato terrace gravels within the size range 16 to 32 millimeters in diameter

85. Mankato morainic topography, Wright County.

86. Glacial map of Iowa with the major Mankato moraines indicated by number

87. View of Ocheyedan Mound, a Mankato morainic feature in Osceola County

88. Map of the Mankato drift area in Iowa showing locations of peat deposits

89. Diagrammatic representation of the depth of leaching of upland gravels in the various drift sheets of Iowa 
Dr. George F. Kay died on July 19, 1943. It is greatly to be regretted that he did not live to see this product of his labors in final print. The first proofs had been revised by him and although the final proofs have been read entirely by others, no changes have been made aside from the correction of obvious errors. 


\title{
THE ILLINOIAN AND POST-ILLINOIAN PLEISTOCENE GEOLOGY OF IOWA
}

\author{
BY GEORGE F. KAY AND JACK B. GRAHAM
}

\author{
Abstract \\ This report makes available in one place the present day evidence and inter- \\ pretations of the Illinoian and Wisconsin glacial stages, and the Sangamon and \\ Recent interglacial stages of the Pleistocene geology of Iowa. \\ Four chapters deal with the following subjects:

$\begin{array}{ll}\text { Chapter I } & \text { The Centralian epoch (series): } \\ & \text { The Illinoian glacial age (stage) } \\ \text { Chapter II } & \text { The Centralian epoch (series): } \\ & \text { The Sangamon interglacial age (stage) } \\ \text { Chapter III } & \text { The Eldoran epoch (series): } \\ & \text { The Wisconsin glacial age (stage) } \\ \text { Chapter IV } & \text { The Eldoran epoch (series): }\end{array}$

In chapter I the distribution, origin, and characteristics of the Illinoian drift are discussed; typical sections of the drift are given, and each of the Illinoian drift phases is described in detail, namely, the gumbotil, the oxidized and leached drift, the oxidized and unleached drift, and the unoxidized and unleached drift. Evidence is given for the judgment that the Illinoian drift is on the average about 30 feet thick.

In chapter II interglacial features of Sangamon age are discussed, such as sands and gravels, late Sangamon loess, peat deposits and soils, and Lake Calvin-its origin and history. Sangamon erosion and the record of life of the age are described.

The Loveland formation receives somewhat detailed treatment. The history of the formation is outlined, sections of Loveland loess and sands and gravels are given, and the results of detailed laboratory studies, involving mechanical and mineral analyses, are presented and their significance indicated. Reference is made to volcanic ash in the formation.

Chapter III includes a discussion of the Iowan glacial subage (substage), the Peorian intraglacial subage (substage), and the Mankato glacial subage (substage).

The Iowan glacial subage (substage) deals with the distribution, origin, and changes in the Iowan drift. Sections of Iowan drift in northeastern and in northwestern Iowa are given. Iowan boulders, the Iowan pebble band, the oxidized and leached Iowan till, and the Iowan gravels-upland gravels and terrace gravels-are described.

The Peorian intraglacial subage (substage) describes in considerable detail the Peorian. loess, its distribution and topographic expression, also typical sections. Mechanical, mineral, and chemical analyses, the vertebrate and invertebrate life and other characteristics, including the depth of leaching and thickness of the loess throughout the State, are presented.

A comparison is made between the Peorian loess and the Loveland loess, the former of which is related in age and, in part, in origin to the Iowan glacial substage; the latter was deposited sometime within the Loveland interval, which includes the time between late Yarmouth age and immediately preIowan age.

The Mankato glacial subage (substage) is described in relation to the distribution of the drift, its origin, and the changes which the drift has undergone. Typical sections of the drift are given and the drift phases are dis: 
cussed in considerable detail. The Mankato gravels-upland gravels and terrace gravels-are described. The thickness of the Mankato drift is discussed.

In chapter IV the record of the Recent subage (substage), the chief features of the Recent and its probable duration are discussed.

Many figures and maps accompany the report.

This report is intended as a complementary' report to the "Pre-Illinoian Pleistocene Geology of Iowa" published by Kay and Apfel more than ten years ago. The two reports will constitute "The Pleistocene Geology of Iowa."

\section{INTRODUCTION}

In the year 1928, "The Pre-Illinoian Pleistocene Geology of Iowa" was published by Kay and Apfel in Volume XXXIV of the reports of the Iowa Geological Survey. Exclusive of the Preface, Introduction, and Concluding Statements, this report contained the following chapters:

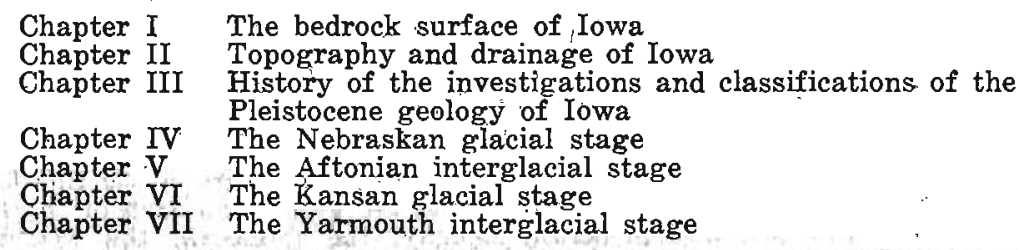

When this pre-Illinoian part of the Pleistocene geology of Iowa was prepared, it was the hope of the senior author that at some later time an equally comprehensive report might be prepared on that part of the Pleistocene of Iowa not discussed in detail in the pre-Illinoian report. Such a report has now been completed and is being presented for publication. It is entitled "The Illinoian and Post-Illinoian Pleistocene Geology of Iowa." In the preparation of this report there has been no hesitation about using many facts which have appeared in former papers dealing with the Pleistocene of the state. The report will make available in one place the present day evidence and interpretations of the Illinoian and Wisconsin glacial stages and the Sangamon and Recent interglacial stages of the Pleistocene of Iowa.

When the report on the pre-Illinoian Pleistocene geology of Iowa was published, it seemed wise to set aside 500 unbound copies with the purpose in mind that after the Illinoian and post-lllinoian Pleistocene geology report had been published, the two reports, 500 copies of each report, should be bound together and designated "The Pleistocene Geology of Iowa." Part I would be "The PreIllinoian Pleistocene Geology of Iowa" and part II, "The Illinoian and Post-Illinoian Pleistocene Geology of Iowa." This plan will be followed. It is intended also to include in this "Pleistocene Geology 
of Iowa" a bibliography of the Pleistocene of Iowa and adjacent states of the Mississippi Valley.

Since the publication of the pre-Illinoian report, 'some significant papers have been published by the senior author. Chief among these are the following:

Classification and duration of the Pleistocene period: Geol. Soc. America Bull., vol. 42 , pp. $425-466$, 1931 .

Origin of the pebble band on Iowan till: Jour. Geology, vol. 39 , no. 4, Mày-June 1931.

(With M. M. Leighton) The Eldoran epoch of the Pleistocene period: Geol. Soc. America Bull., vol. 44, pp. 669-673, 1933.

Pleistocene history and early man in America: Geol. Soc. America Bull., vol. 50, pp. 453-464,-1939:

The classifications of the Pleistocene of the Mississippi Valley and of. Iowa are recognized by the Iowa Geological Survey as follows :

Classification of Pleistocene geology in the Mississippi Valley

\begin{tabular}{clll}
\hline Period (System) & Epoch (Series) & Age (Stage) & Subage (Substage) \\
\hline & Eldoran & Recent & Mankato \\
Pleistocene & & Wisconsin & $\begin{array}{c}\text { Cary } \\
\text { Tazewell } \\
\text { Iowan }\end{array}$ \\
or & Centralian & $\begin{array}{l}\text { Sangamon } \\
\text { Illinoian }\end{array}$ & \\
Glacial & Ottumwan & Yarmouth \\
& Gansän & \\
& Grandian & Aftonian & \\
& & Nebraskan & \\
\hline
\end{tabular}

Classification of the Pleistocene geology of Iowa

\begin{tabular}{|c|c|c|c|c|}
\hline Period (System) & Epoch (Series) & Age (Stage) & Subage & (Substage) \\
\hline \multirow{5}{*}{$\begin{array}{l}\text { Pleistocene } \\
\text { or } \\
\text { Glacial }\end{array}$} & \multirow[b]{2}{*}{ Eldoran } & Recent & \multirow{3}{*}{$\begin{array}{l}\text { Mankato } \\
\text { Peorian } \\
\text { Iowan }\end{array}$} & \\
\hline & & Wisconsin & & \\
\hline & Centralian & $\begin{array}{l}\text { Sangamon } \\
\text { Illinoian }\end{array}$ & & \\
\hline & Ottumwan & $\begin{array}{l}\text { Yarmouth } \\
\text { Kansan }\end{array}$ & & \\
\hline & Grandian & $\begin{array}{l}\text { Aftonian } \\
\text { Nebraskan }\end{array}$ & & ' \\
\hline
\end{tabular}


The chapters of the report on the Illinoian and the post-lllinoian Pleistocene geology of Iowa are as follows:

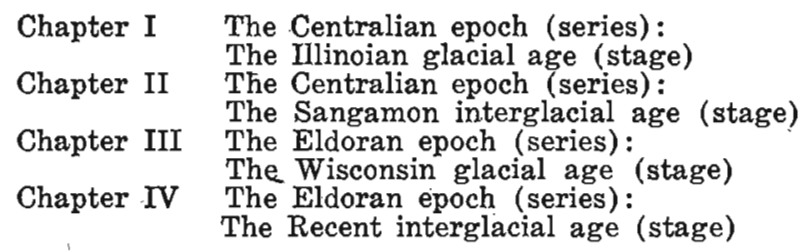

The authors wish to acknowledge their obligation to the late Dr. James H. Lees, Assistant State Geologist of Iowa from 1906 until 1934; also to express their thanks to Dr. E. T. Apfel, Dr. Paul T. Miller, Dr. Neil A. Miner, Dr. R. W. Edmund, and Dr. Cornelia C. Cameron. Results of their studies have been drawn upon freely and used in various ways in this report. 


\section{CHAPTER I, \\ THE CENTRALIAN EPOCH (SERIES) THE ILLINOIAN GLACIAL AGE (STAGE)}

Discrimination of the Illinoian drift

Distribution of the Illinoian drift in Iowa

Origin of the drift

Changes in the drift

Typical sections of the Illinaian drift

Descriptions of the drift phases.

The Illinoian gumbotil

Oxidized and leached.Illinoian till

Oxidized and unleached Illinoian till

Unoxidized and unleached Illinoian till

Thickness of the Illinoian drift

The Centralian epoch $\left(\right.$ series) ${ }^{x}$ includes the Illinoian glacial age (stage) and the Sangamon interglacial age (stage). The Illinoian glacial age followed the Yarmouth interglacial age and is; the third of the glacial ages in the Pleistocene period. The glacial drift of * the Illinoian age was first distinguished by Leverett. ${ }^{2}$ It was described by him in 1899 in his monograph on the Illinois glacial lobe and was named from the State of Illinois, where he had made his most extensive studies of the drift sheet. It was first named the Illinois glacial lobe, but the name has been changed by later usage to Illinoian to agree with the names of other stages. The Illinoian was the last drift sheet to be differentiated in the Mississippi Valley although the Nebraskan drift did not receive its present name until ten years later, in 1909, when Shimek ${ }^{3}$ gave that name to the drift sheet that had previously" gone by the nondescript names of SubAftonian and Pre-Kansan. The glacial map of Iowa; figure 1, shows the drift sheets and other glacial features of the state.

The Illinoian ice sheet came into Iowa from the Labradorean center. The drift left by this ice sheet is exposed widely in Illinois, Indiana, and Ohio.

\section{DISCRIMINATION OF THE ILLINOIAN DRIFT}

For the most part the Illinoian drift is similar to the older drifts on which it lies. It is typically a dark-gray clay with unassorted pebbles of varied kinds and sizes. Boulders are present, but large ones are uncommon. However, one granite erratic was observed

\footnotetext{
rKay, G. F., Classification and duration of the Pleistocene period: Geol. Soc. America Bull., vol. 42, pp. 448-452, 1931 .

2Leverett, Frank, The Illinois glacial lobe: U: S. Geol. Survey Mon. 38, 1899.

sShimek, Bohumil, Aftonian sand and gravels in western Iowa: Geol. Soc. America Bull., vol. 20 , pp. $399-408,1909$.
} 


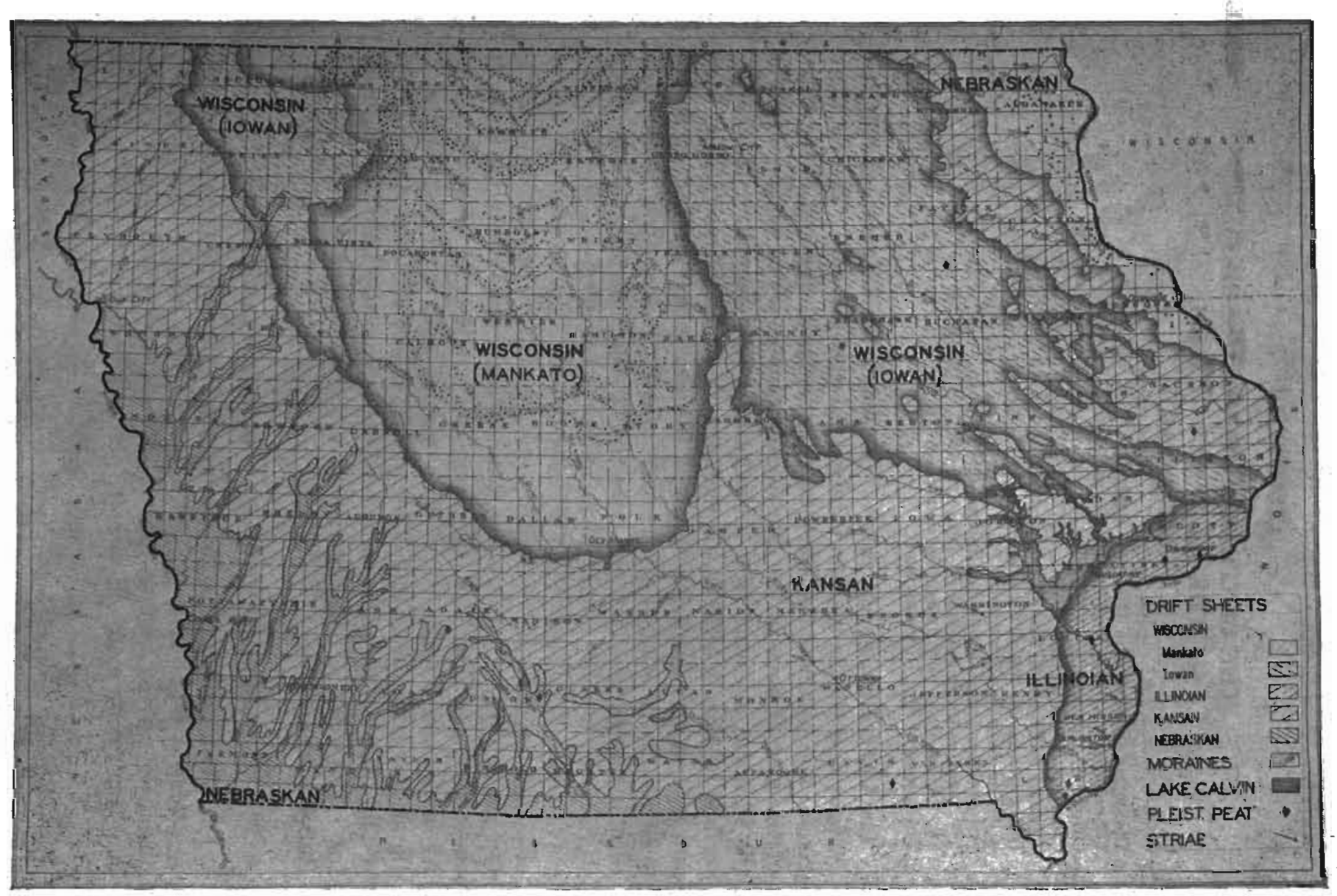

Figure 1. Map-showing the surface distribution of the drift sheets and other glacial features of Iowa. 
the dimensions of which above ground were 24 by 21 by 10 feet: In places the Illinoian till seems to be rather lighter in color than are the typical Kansan and Nebraskan tills, and at other places it is quite'sandy. This sandy feature, however, is shared by all the drift sheets. Like the other drift sheets also, this one includes great pockets or lenses of gravels that either are surrounded by till or lie on its surface. The best known example of these gravels is in the valley of Mad Creek in the northeastern outskirts of Muscatine. That the Illinoian drift sheet has passed through essentially the same succession of events as had the older sheets before it is indicated by the presence over its upper surface of gumbotil as much like the Kansan and Nebraskan gumbotils as those tills are like the Illinoian till. This difference is to be noted, however, that whereas the Nebraskan and Kansan gumbotils average above 8 and about 11 feet in thickness respectively, the average maximum thickness of the Illinoian gumbotil is less than 5 feet. It is evident that conditions favorable for gumbotil formation were not so long continued after the uncovering of the Illinoian drift sheet as after the formation of the older ones. Such gravels as lay at or near the surface of the drift were strongly leached until their soluble constituents' were removed entirely from the upper parts.

Normally, the Illinoian drift rests on Kansan gumbotil or, where this was eroded before the oncoming of the Illinoian glacier, on Kansan till in various stages of oxidation and leaching or on Kansan gravels. Kansan drift caps the Nebraskan drift everywhere within the area in Iowa covered by the Illinoian drift sheet, and it is not known that the Kansan was anywhere entirely eroded from above the Nebraskan, allowing the Illinoian drift to rest directly on Nebraskan.

Above the Illinoian materials may be found late Sangamon or Loveland loess, soil or peat, Peorian loess and wind-blown sand. Perhaps Iowan drift overlies Illinoian in the area of their contact, but this has not been seen on account of the thickness of the loess and sand in this region. The loess and sand materials have been seen on Illinoian gumbotil and on both the leached and unleached phases of the oxidized till.

Because the different drift sheets resemble each other in general composition and character, it is difficult to distinguish them when similar phases are found in contact. 'If unleached Illinoian till lies directly on unleached Kansan till the two might not be distinguishable. It is much more common, however, to find yellow oxidized 


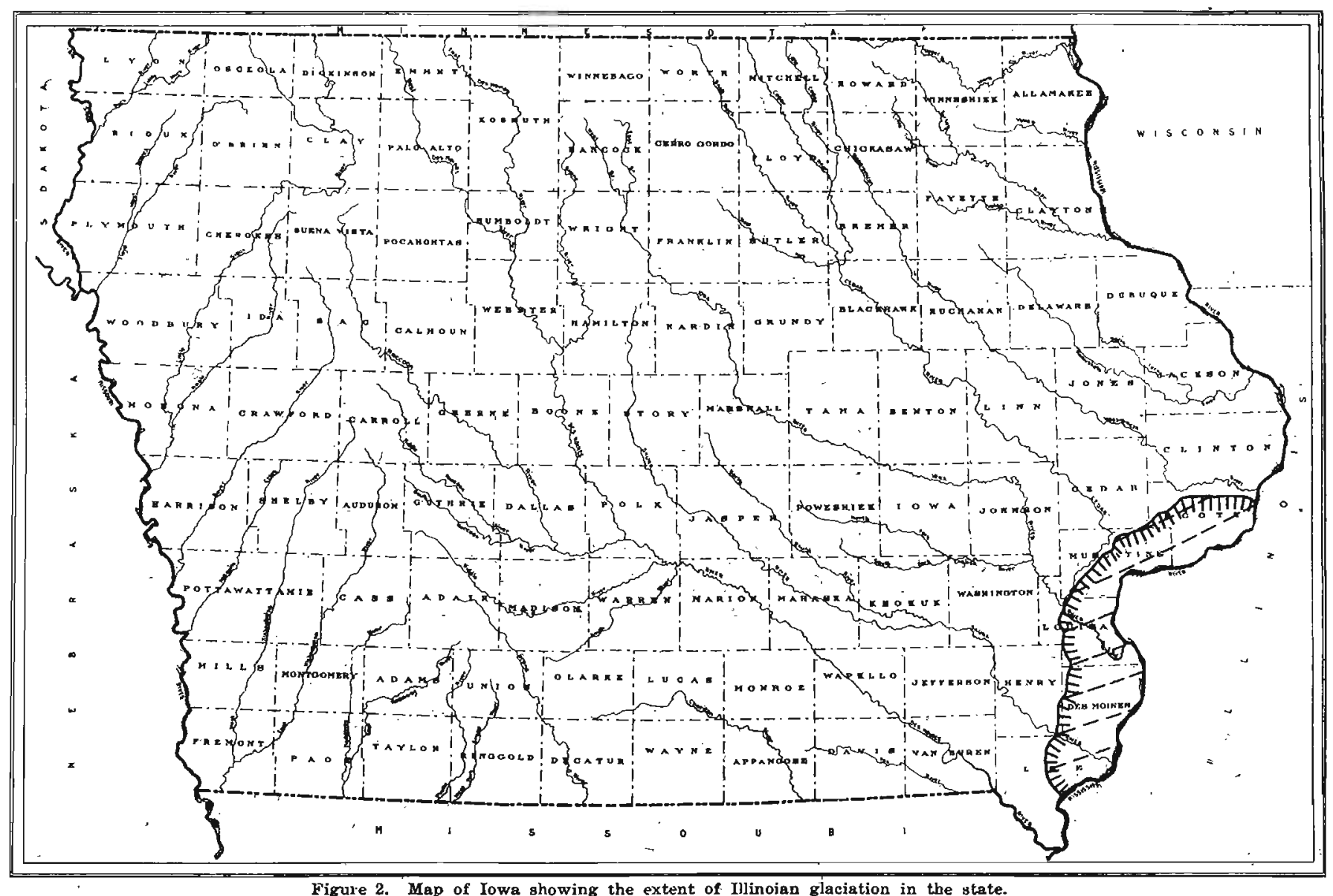


till, either leached or unleached, on Kansan gumbotil. In this case the upper till may be called Illinoian with assurance; and where any other unlike phases lie in contact, their ages may be known with equal certainty.

\section{DISTRIBUTION OF THE ILLINOIAN DRIFT IN IOWA}

The Illinoian glacier was near its maximum extent when it reached the Mississippi River on its long journey from the Labradorean center of dispersion. Therefore, it pushed over into Iowa for only a few miles; and the sheet of drift that it left has a width west of the Mississippi ranging from about 4 miles at Muscatine to about 20 miles a short distance north of Burlington. The northern limit of the drift is probably somewhere near the mouth of the Wapsipinicon River and its southern extremity in Iowa is just south of Fort Madison. Some parts of the margin grade indefinably into the Kansan drift plain; elsewhere, as at West Point, a distinct moraine marks the boundary between the two plains; and between Stockton, Moscow, and Columbus Junction, a low area, the site of glacial Lake Calvin, follows the edge of the Illinoian glacial lobe, figure 2 .

The Illinoian ground moraine must have been level, for the gumbotil plain that was developed on it, like that on the Kansan ground moraine, stretched out smoothly for miles. The two main drainage lines that cross it, Iowa and Skunk Rivers, have wide valleys that are incised far below the plain, and in general a dendritic drainage system is fairly well developed. Nevertheless, wide areas of the gumbotil plain still remain, modified only by the deposition.over them of several feet of loess. This loess bears decisive evidence of being of two ages, because in places a lower body of compact leached loess is overlain by unleached loess that grades up into leached loess. The lower loess is late Sangamon or Loveland in age; that is, post-Illinoian gumbotil, while the upper loess is the Peorian loess of Iowan age and post-Iowan age. While the Loveland loess is not universally present in the Illinoian area, its exposures are so generally distributed that there is warrant in assuming that its original extent over the Illinoian drift was comparable to that of the Peorian loess in early Wisconsin time.

When the Illinoian glacier crossed the Mississippi Valley, it filled this valley with ice and glacial debris and forced the river to find a new course around the advancing front of the ice sheet. This stream course must have continually changed with the altering ice 
front, but when the ice finally came to rest; the waters of the river were ponded by the high lands near Columbus. Junction and eventually formed a lake that covered the present lower course of Cedar River and extended far up the Cedar and Iowa valleys. This body of water has been named Lake Calvin, and its history has been traced in detail by Schoewe ${ }^{4}$ and outlined in a later part of this report.

\section{ORIGIN OF THE DRIFT}

The Illinoian drift undoubtedly was derived in very large measure from the older drift sheets over which it passed. These were the Nebraskan and the Kansan; but to what extent the Illinoian glacier found each of these drift sheets at the surface is, of course, undetermined, as eomparatively little is known of the distribution of these drifts in the states east of Iowa. Because the two earlier glaciers came from west of Hudson Bay while the Illinoian came from the Labrador peninsula, the course of the later glacier would be nearly at right angles to that of the earlier ones, and it is quite possible that boulders and other material that originated in the Keewatin region and that lodged in the states south of the Great Lakes may have been moved westward later by the Illinoian ice as far as western Illinois or Iowa.

The erosive work of the Illinoian glacier would naturally be, in the first place, to remove any interglacial materials that had accumulated on the older drift sheets or' in valleys cut into them. Next would come the cutting away of the gumbotils, then of the oxidized and leached tills, the oxidized and unleached tills, and, if erosion proceeded far enough, the upper parts of the unoxidized and unleached tills. With such a body of leached materials to be scraped off, it seems remarkable that the Illinoian drift, as it was finally constituted, should have contained much calcareous matter. The fact, however, that any section of Illinoian drift that exposes a thickness of 10 feet or more does show unleached material is evidence that the Illinoian ice did plow deeply into the unleached till and probably, locally at least, into the bedrock beneath.

The Illinoian drift sheet, then, comprises unsorted and unstratified bodies of clay and coarser material; in other, words, typical glacial till; and also masses of sand and gravel that were more or less assorted and laid down às bedded deposits.

¿Schoewe; Walter H., The origin and history of extinct Lake Calvin: Iowa Geol. Survey, vol, 29, DD. 49-222, 1920 . 


\section{CHANGES IN THE DRIFT}

As soon as the Illinoian drift, both till and gravel, was uncovered, it became subject to the action of weathering and other physical and chemical agencies. Rains and their consequent surface and subsurface waters began to dissolve and reassort and otherwise modify the materials of the drift. Plants and animals would alter the texture and composition of the till, and the gases of the atmosphere and those produced by chemical reactions would aid in this work of change. It was not long until oxidation of the iron content and perhaps of other components as well altered the color of the upper part of the drift from its original gray to a yellowish tinge. Accompanying this oxidation, although much slower, was the leaching of the lime carbonate and probably other'readily soluble elements and the carrying away of these materials in the ground water. The single unleached and unoxidized zone of the original, fresh, unaltered drift sheet would thus soon be divided into two zones, the upper of which was oxidized although still unleached, and as alteration progressed downward, a third zone would be introduced, the uppermost leached zone. But alteration has not stopped at this stage, and the leached matter has been still further modified; the clay constituents have been broken down into simpler compounds, some of which have been carried out; the sands, gravels, and even the boulders removed until at present the upper few feet of the till contains practically no boulders and only a few pebbles, these being of the most nearly insoluble types only. This residual material is the Illinoian gumbotil and it seems to have covered practically all the Illinoian drift plain. Illinoian gumbotil is exceptionally widespread in Illinois. Detailed studies in that state have resulted in the recognition of zones equivalent to the gumbotil, but which reflect different types of drainage sufficiently to merit separate recognition. Thus, typical, flat upland areas with poor drainage result in gumbotil.' Well-drained areas result in a silty, comparatively open-textured material termed silttil. An intermediate condition of drainage results in a product which is intermediate in texture (between gumbotil and silttil); known as mesotil. ${ }^{5}$

It seems remarkable that the thoroughly leached material that lies beneath the gumbotil and that grades upward into it should have a thickness of not over 3 feet in most places. This seems to indicate that leaching progresses very slowly under the protective

\footnotetext{
'Leighton, M. M., and MacClintock, Paul, Weathered zones of the drift-sheets of Illinois : Jour. Geology, vol. 38, pp. 38-45, 1930 .
} 


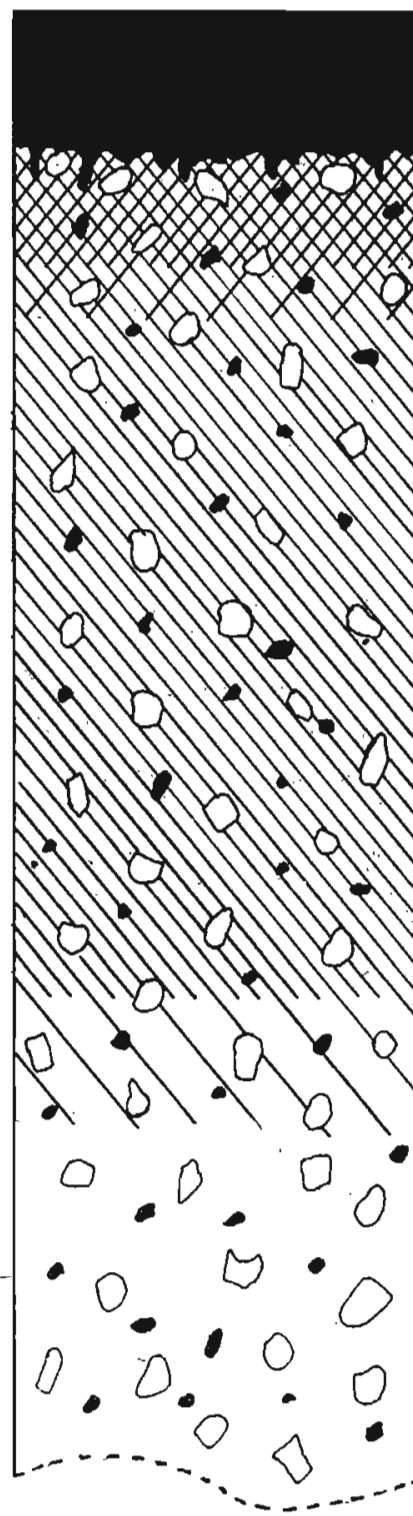

SANGAMON INTILRGIACIAI

OX'IDIZED AND

UNLEACHED TILL

OXIDIZED AND
LFACHED TILL

IIIINOIAN

Figure 3. Diagram of a complete normal section' of Illinoian till. 
cover of the gumbotil. Complete sections of the Illinoian may be seen today in which the till is oxidized to a depth of 30 feet, but in which leaching has advanced only 2 to 7 feet below the gumbotil.

However, weathering does not stop with the development of gumbotil; in places this layer is still further changed until the sticky, compact, gummy clay is robbed of some of the constituents that give it this character, and it becomes a mealy, almost loamlike clay. Figure 3 is a diagrammatic representation of a typical section of Illinoian till showing the succession of changes which are found in Iowa. This sequence of till phases is also known as the soil profile, and the profile of weathering.

In Illinois, much work has been done on these zones of weathering. The various horizons have been numbered and are equivalent to the geologic terminology of the till phases as used in Iowa, as shown in, the following table:

$\begin{array}{ll} & \begin{array}{l}\text { Soil profile } \\ \text { horizon number }\end{array} \\ \text { Gumbotil } & \begin{array}{l}\text { Horizon } 1 \text { (surficial soil) } \\ \text { Horizon } 2\end{array} \\ \text { Oxidized and leached phase } & \text { Horizon } 3 \\ \text { Unoxidized and unleached phase } & \text { Horizon } 4 \\ \text { Unomeached phase } & \text { Horizon } 5\end{array}$

In the case of gravels lying near the surface similar alteration may be expected to take place. Oxfdation and leaching would progress much as in till until the soluble pebbles would be removed. It seems probable that further weathering of igneous materials might even form a residuum similar to gumbotil. Such material has been given the name gumbosand. ${ }^{7}$

${ }^{6}$ Leighton, M. M., and MacClintock, Paul, op. cit., p. 32.

'Leighton, M. M., and MacClintock, Paul, op. cit., p. 41. 


\section{TYPICAL SECTIONS OF THE ILLINOIAN DRIFT Exposures in Scott County}

One of the most complete sections of the Illinoian till and of the associated overlying and underlying materials is exposed in the southwest environs of Davenport, in the SE1/4 sec. 30, Rockingham Township, (T. 78 N., R. 3 E.), Scott County. State highway 22 descends the Mississippi valley wall through a ravine and joins U. S. highway 61 near the foot of the bluff. About one-half mile west of the junction the following section may be studied on the north side of the road as one descends from the Illinoian upland:

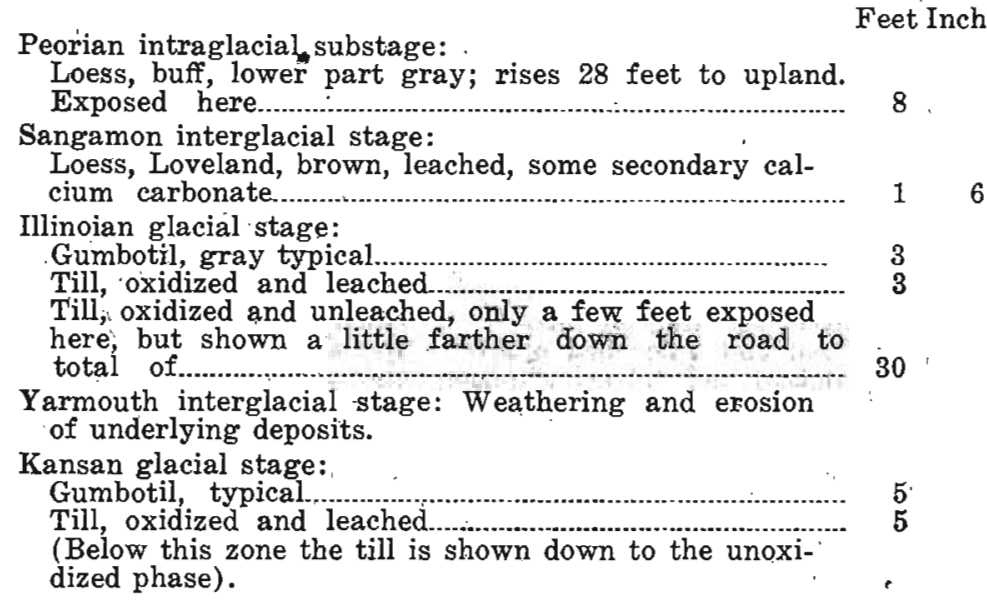

The upland here lies about 760 feet above sea level; therefore, the elevation of the Illinoian gumbotil is about 730 feet, and that of the Kansan, about 695 .

A number of road cuts and other exposures in Scott County show interesting phases of the Illinoian and post-Illinoian materials. Near the Wapsipinicon River the Peorian loess is thin and the till shows through in numerous places. But 3 or 4 miles from the river the loess thickens to 10 or 15 feet or more and no till is seen. Probably this is within the Illinoian area. In the vicinity of Eldridge, the Illinoian plain is quite markedly level. Here the loess is 12 to 15 feet thick and overlies gumbotil which averages about 3 to 4 feet in thickness. A road grading just west of the corners of secs. 8, 9, 16, and 17, Lincoln Township, (T. 79 N., R. 4 E.), is interesting as showing the leaching of loess on the level Illinoian plain. It exposes the following: 
Peorian intraglacial substage:

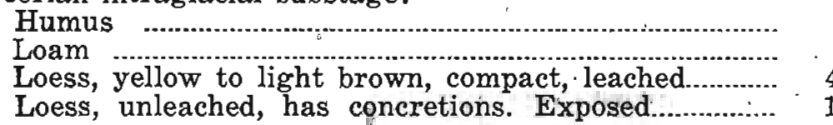

Loess, unleached, has concretions, Exposed

Feet Inches

About $1 \frac{1}{2}$, miles southeast from this exposure, in the NW1/4 sec. 22, Lincoln Township, (T. 79 N., R. 4 E.), the topopraphy shows a relief of about 30 feet, all of which appears to be in loess. Here is an outcrop of two loesses, the upper one, Peorian, being buff and leached in its upper part, gray and calcareous below, with iron tubules. The basal part of the exposure shows 3 to 4 feet of Loveland loess in irregular contact with the Peorian. The upper foot of the Loveland is dark with carbonaceous matter while the lower 3 feet is brown. It is all leached although it contains some lime concretions that were precipitated from the calcareous loess above.

Another section near the one just described carries the sequence somewhat further down the series. It is on a hillside near the NE1/4 sec. 27, Le Claire Township, (T. 79 N., R. 5 E.), on the road leading down to Le Claire. Along the roadside Illinoian gumbotil is exposed more than 40 feet below the upland, and over it is loess, apparently all Peorian. Oxidized and unleached Illinoian till outcrops about 10 feet below the gumbotil.

Several sections in Davenport show some phases of the series of events that are not everywhere to be seen. One of these is.just south of the high school building between Harrison and Main Streets. When studied it showed:

Peorian intraglacial substage:

Loess, buff colored, unleached

Feet

Sangamon interglacial stage:

Loess, Loveland, purplish, leached.................................. 4

Illinoiar glacial stage:

Till, reddish, oxidized, leached, the result of leaching of the colloids from the Illinoian gumbotil; therefore, secondary profile

(This member shows a long lapse of time between the development of the gumbotil and the formation of the late Sangamon loess)

Till, oxidized, unleached, many concretions. Lower part unoxidized and unleached. Exposed.

\section{Exposures in Muscatine County}

A cut along State highway 22, in the middle of the E $1 / 2$ sec. 36 , Fulton Township, (T. 78 N., R. 1 E.), Muscatine County, where the road turns northwest, about a mile northwest of Blue Grass, shows 
in an interesting way the relation of the Illinoian to the Kansan till. 8 . The section is as follows:

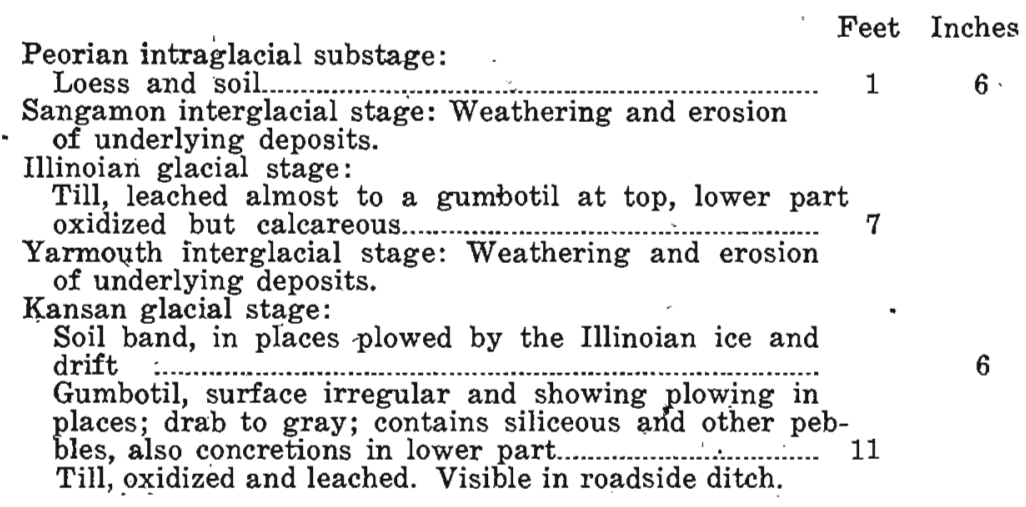

The Kansan gumbotil is about 715 feet above sea level and the upland lies 50 feet higher than this, at least 40 feet of this being in loess. A similar exposure of gumbotil overlain by Illinoian till occurs about one-half mile northwest of this one on the north line of sec. 36.

A large body of gravels of Illinoian age is exposed in a small branch of Mad Creek in the southwest corner of sec. 23 and the southeast corner of sec. 22, Bloomington Township, (T. 77 N., R. 2 W.). These gravels are evidently pockets in the till and because they rise nearly to the upland level, they show weathering features similar to those produced in the drift. The gravels are highly oxidized and reddened and cemented by iron oxide in the upper part; but, for the most part, are light grayish-buff in color. The gravels are leached for 7 feet. Oxidation has advanced 12 feet below the upland level and the fact that the overlying loess, 15 feet in thickness, is leached for only about 5 feet demonstrates that the leaching of the gravels is pre-Peorian. Elsewhere the gravels of this mass seem. to have been eroded in connection with the cutting out of Mad Creek Valley, and less leaching is shown here than maximum Sangamon leaching, which has been found to be about 12 feet.

\section{Exposures in Louisa County}

In the SE $1 / 4$ sec. 26 , Grandview Township, (T. 75 N., R. 3 W.), Louisa County, a gully has worked back from a small tributary of the Mississippi River and has exposed a fine section of the Illinoian

\footnotetext{
8Kay, G. F., and Apfel, E. T., The pre-Illinoian Pleistocene geology of Iowa: Iowa Geol. Survey, vol. 34, p. $260,1929$.
} 
drift about 200 yards east of the diagonal road. The surface in the vicinity is level upland and the whole association must give a picture of conditions about as they have persisted since Peorian time. The section is as follows:

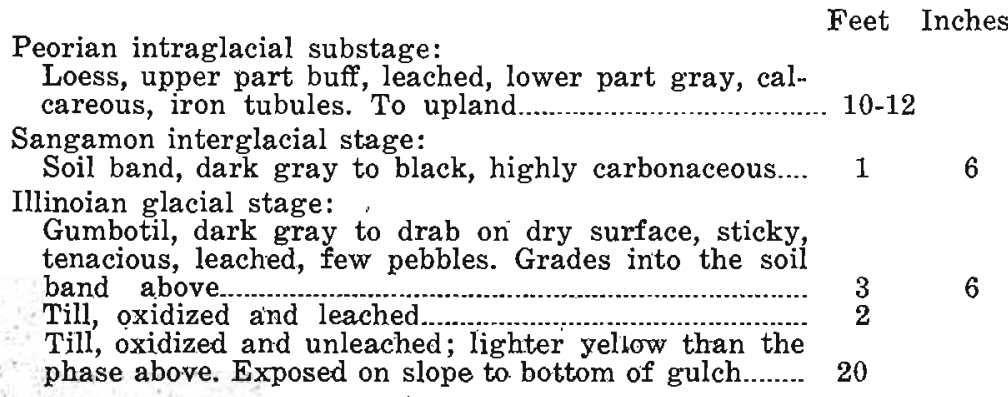

This is one of the clearest-sections of the Illinoian to be found within its area. The gumbotil is about 650 feet above sea level and, in its relation with the soil band, illustrates the very gentle slope of the original gumbotil plain.

On the north bluff of Iowa River Valley, in the center of the SW $1 / 4$ sec. 4, Grandview Township, (T. 74 N., R. 3 W.), is an interesting exposure. The uppermost material is loess and wind-blown sand, both of which were derived, doubtless, from the river bottoms near-by. The gumbotil is carbonaceous in its upper part and is very dark, almost black in color, and very sticky. It is here about $2 \frac{1}{2}$ feet thick although a nearby section shows 5 feet of gumbotil. The lower part of the gumbotil contains sand pockets and some lime concretions. It lies about 20 feet below the upland.

\section{Exposures in Des Moines and Henry Counties}

The Illinoian gumbotil upland, overlain by loess, is wonderfully developed in Des Moines County. U. S. highways 61 from Burlington north through Mediapolis and 34 from Burlington west and northwest through New London stretch across this plain. and give very typical views of a topography that must have endured with but slight change since the Illinoian glacier melted back from this area many thousands of years ago. Because of this level character and slight erosion, deep exposures of the drift are uncommon. However, a number of shallow cuts show that the same materials are present here as elsewhere in the area covered by the Illinoian ice. The abandoned brickyard at Mediapolis still shows beneath about 2 feet of dark soil a Peorian loess that is light gray mottled 
with brown., The lower half is somewhat lighter than the upper half, but the whole body, 6 feet in thickness, is noncalcareous showing that leaching here has progressed 8 feet from the surface since the beginning of Peorian deposition. Under this loess is Loveland loess exposed to water level 3 feet, leached, drab, evidently much older than the upper loess (fig. 4).

South of Latty and east of the railroad station, in sec. 29, Benton Township, (T. 71 N., R. 2 W.), is a section as follows:

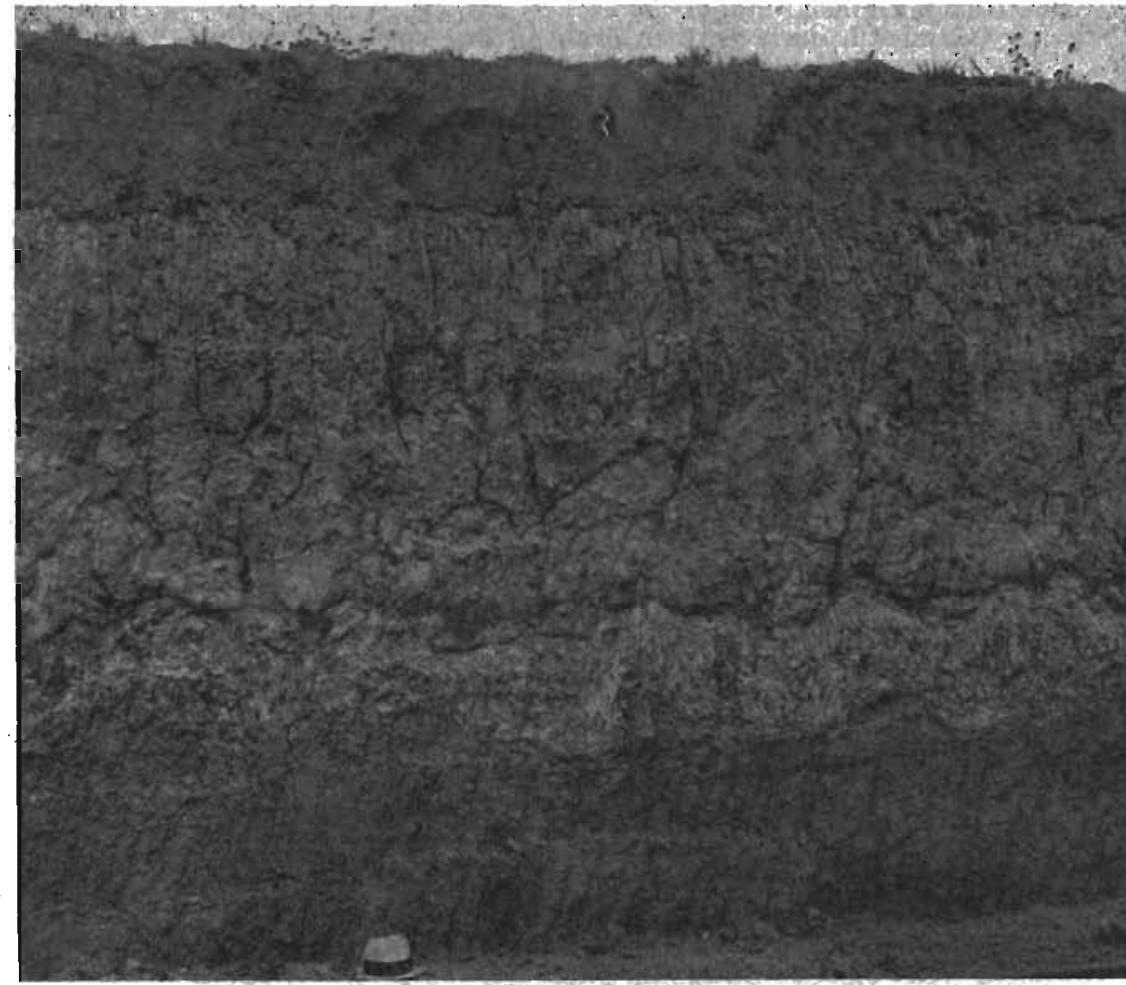

Figure 4, Exposure showing dark soil, Peorian loess, and Loveland loéss. Brick and Tile plant, Mediapolis, Des Moines County.

Peorian intraglacial substage:

Feet Inches Loess

Sangamon interglacial stage:- Weathering and erosion of underlying deposits.

Illinoian glacial stage:

Gumbotil, drab, typical

Till, oxidized and leached.

Till, oxidized and unleached. Several feet exposed. 
Latty is just below the upland; consequently, this section reveals a condition almost unmodified since Illinoian time except by wedthering and by deposition of Peorian loess.

Kay and Apfel $^{9}$ described a fine section of Illinoian drift over Kansan drift just south of New London. It is on the south slope of a small creek valley and is along the road leading toward Lowell, in the NE $1 / 4$ sec. 34 , New London Township, (T. 71 N., R. 5 W.). The record is as follows:

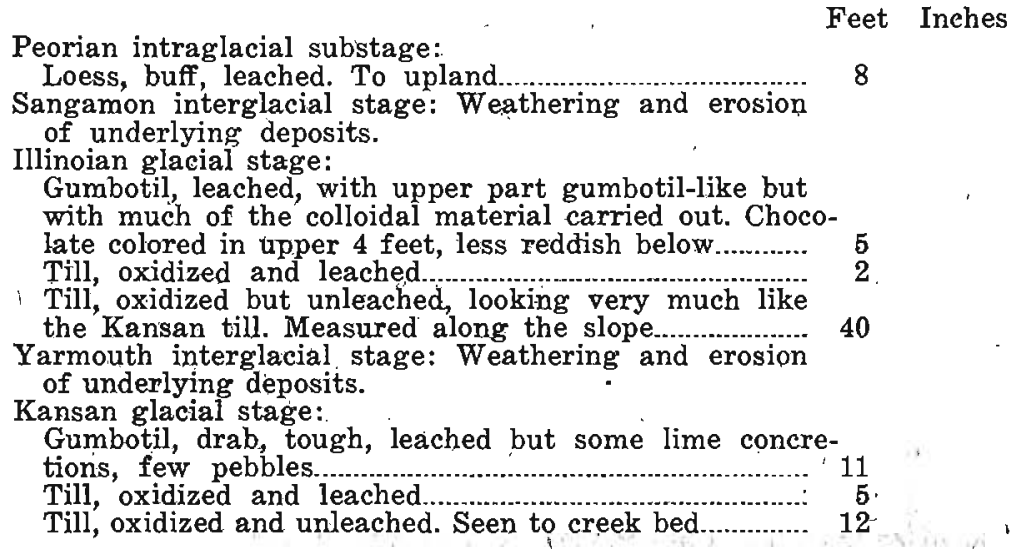

This shows one of the thickest sections of Illinoian till seen in this state. The gumbotil and leached till are both of normal thickness for the Illinoian drift.

\section{Exposures in Lee County}

Only the eastern quarter of Lee County was covered by Illinoian ice, but within this area are now exposed some very clear sections of glacial materials. A ravine in the west part of sec. 20, Denmark Township, (T. 69 N., R. 4 W.), has been cut through unleached but oxidized Illinoian till that is about 20 feet thick. It lies on Kansan gumbotil that is dark above and gray below. In places at the gumbotil level are to be seen gravel masses that have been leached and reddened during the processes that changed the till to gumbotil.

An exposure that shows the thinnest section of Illinoian till so far seen is in a gulch that is cutting back from Mississippi River in the SW $1 / 4 \mathrm{NE}^{1 / 4}$ sec. 35, Washington Township, (T. 68 N., R. 4 W.), on the south side of U. S. highway 61 . The section is:

\footnotetext{
oKay, G. F., and Apfel; E. T., The pre-Illinoian Pleistocene geology of Iowa: Jowa Geol. Survey, vel. 34, p. 228,1929 .
} 
Peorian intraglacial substage:

Feet Inches

Loess-like clay, grayish to yellowish, leached

Sangamon interglacial stage: Weathering and erosion of underlying deposits.

Illinoian glacial stage:

Gumbotil, gray to drab, some concretions, some chocolate color in mottling. Few pebbles. Till, oxidized, leached, some patches of gray gumbotil-like material; in places has many pebbles...............

Yarmouth interglacial stage: Weathering and erosion of underlying deposits.

Kansan glacial stage:

Gumbotil, gray to drab, concretions

Till, oxidized and leached

Till, oxidized and unleached.

Till, unoxidized and unleached. Basal contact not seen.

Near the southeast corner of sec. 33, Washington Township, (T. 68 N., R. 4 W.), close to the city limits of Fort Madison, is a gully that is cutting into the edge of the upland that here reaches to the valley of the Mississippi River. This gully has exposed an exceptionally good section of the Illinoian. One remarkable feature of the topography here is that as the observer stands at the head of this ravine, he may look across the city to the river and the Illinois bluffs beyond; and yet the water in this ravine flows away from the river to a small tributary that eventually does empty into the Mississippi. The section exposed is as follows:

Peorian intraglacial substage:

Feet Inches

Loess, grayish yellow to buff yellow, leached

Sangamon interglacial stage: Weathering and erosion of underlying deposits.

Illinoian glacial stage:

Gumbotil, drab to chocolate brown or dark color, starch-like fracture, few pebbles, leached; grades into

- underlying till

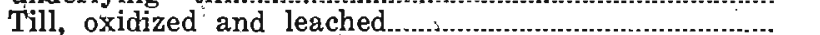

Till, oxidized and unleached. To base of gulch........... 15

Several sections east of West Point show a normal succession of thin Illinoian over Kansan. One of these is along the roadside between the SW $1 / 4$ sec. 34, Pleasant Ridge Township, (T. 69 N., R. 5 W.), and the NW $1 / 4$ sec. 3 , West Point Township, (T. 68 N., R. 5 W.). From the road corner westward this shows:

Peorian intraglacial substage:

Feet Inçhes

Loess-like clay, about.

Sangamon interglacial stage: Weathering and erosion of underlying deposits.

Illinoian glacial stage:

Gumbotil, about

Till, oxidized, unleached in lower part; contains much chert 
Yarmouth interglacial stage:

Soil zone, loess-like, light gray above, black below, with carbonaceous streaks

Gumbotil, exposed

This section is only about 2 miles from the margin of the Illinoian.

A series of natural exposures along the ravine followed by the Batavia branch of the Chicago, Burlington and Quincy Railroad in the southwest part of sec. 28, Washington Township, (T. 68 N., R. 4 W.), affords one of the best Pleistocene sections in the state. These have been described by Kay and Apfel ${ }^{10}$ and need be only summarized here. The section is as follows:

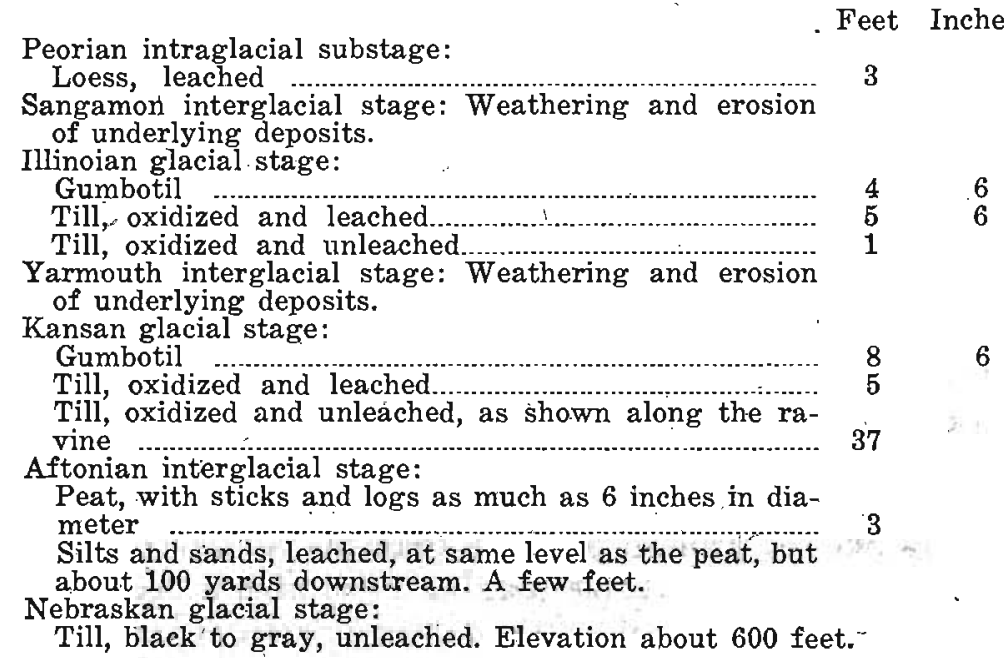

This section begins just back of a farmhouse on State highway 103 at the bend in the southwest corner of sec. 28 and extends for half a mile down the valley along the railroad. The different elements have differing thicknesses in their various outcrops, but the above shows the general succession.

\section{DESCRIPTIONS OF THE DRIFT PHASES The Illinoian Gumbotil}

The Illinoian gumbotil is the most distinctive phase of the Illinoian drift. As in the formation of the Nebraskan and Kansan gumbotils, weathering under favorable conditions has produced a zone which contrasts sharply in color and texture with other Illinoian drift phases. The color of the gumbotil is essentially drab

\footnotetext{
${ }^{10} \mathrm{Kay}, \mathrm{G}$. F., and Apfel, E. T., The pre-Illinoian Pleistocene geology of I'owa: Iowa Geol Survey, vol. 34 , pp. 149-151, 226-227, 1829 .
} 
gray when dry, as in the two older gumbotils. On a fresh surface the gray is slightly mottled with brown. When wet, the gumbotil is dark, with color variations in the zone becoming more distinct. In many cases, the jointed and fractured polyhedral blocks, at or near the surface, are stained with the yellowish brown colors of an iron oxide coating.

The textural character of the Illinoian gumbotil is a second prominent feature by which it may be distinguished readily from other drift phases. Upon drying, the gumbotil tends to joint and fracture due to shrinking volume and the widening of these cracks produces the typical minute polyhedral blocks which are characteristic of gumbotil. The joints are irregular in extension and face, but are so well developed that fracture of the material is uncommon, separation in most cases being along the joints. The blocks produced by separation along these joints are polyhedral with wedge shapes predominating, from 1 to 5 or 6 millimeters in dimension. A secondary set of joints spaced a centimeter or more apart shows slickensided surfaces in some cases. Root tubules are few, for most of the roots follow the joint lines.

The mass texture, or the relation of the constituent blocks of the mass to one another, is best described as "starch-like" in fracture. This habit is the most readily discernible in gumbotil wet enough to be molded by the hands. In this respect, the Illinoian gumbotil is more like the Kansan gumbotil than the Nebraskan, which does not display the remarkable jointing to so high a degree. The Illinoian gumbotil, as is true of the older gumbotils, exhibits a "hackly appearance" on a dry surface in which the polyhedral blocks are so minutely cracked as to present a crumbly appearance yet re- taining a surprising mass coherence.

The clastic texture, or the character and disposition of the unit rock or mineral particles making up the till deposits; is more evidence of the individuality of gumbotil among the drift phases. The Illinoian gumbotil studied has a general similarity which can be observed in the field, but is much more evident from laboratory studies. The mechanical analyses of the gumbotils from six different locations (fig: 5 ) show a maximum percentage of material in the silt and clay grades below $1 / 64$ millimeter in diameter. In four of the six analyses, more than 65 percent of the material is finer than 1/64 millimeter in diameter while in one sample there is as Iow as 39 percent within this size grade. In five of the analyses, the general decrease in the percentages of each grade varies with 


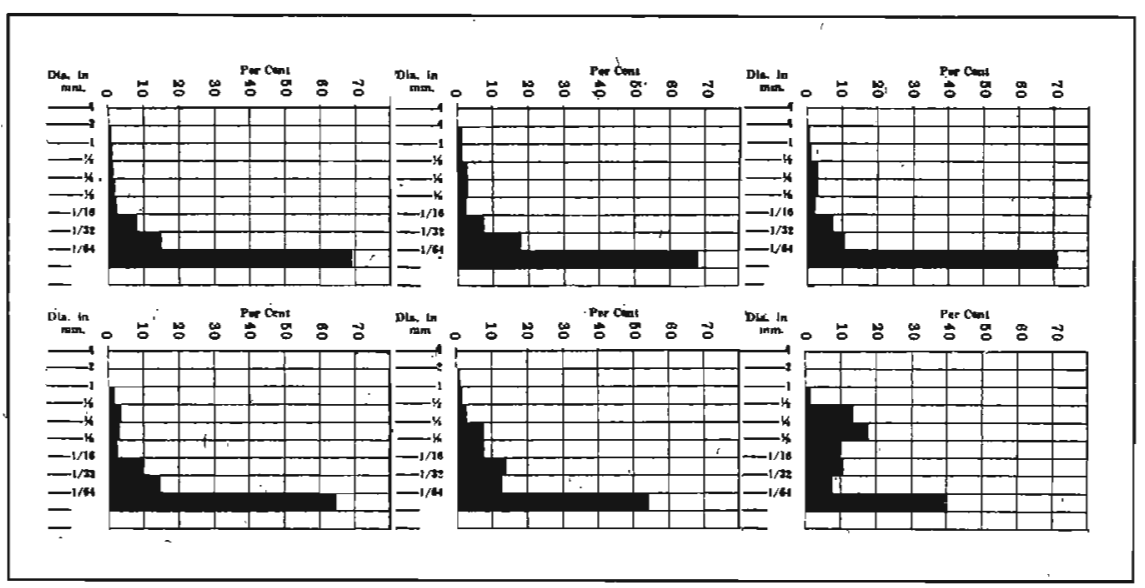

Figure 5. Graphs showing mechanical analyses of Illinoian gumbotil from six different Jocalities.

the increase in the size grades, The other analysis is distinctly different showing a low percentage of material in the size grade below 1/64, millimeter in diameter and more than 30 percent of the sample between $1 / 8$ and $1 / 2$ millimeter which is explained by the sandy texture of the till.

These analyses show that in general the clastic textures of the gumbotils are similar, but at the same time there are variations in the clastic textures of the gumbotils just as found in normal ungumboized till. Not only are there likenesses within the Illinoian gumbotils, but a comparison of an average of the Illinoian gumbotils with the Nebraskan and Kansan gumbotils (fig. 6) shows that the analyses of all of the gumbotils, although of different ages, are so much alike that it would be impossible to differentiate the different ages of gumbotil on the basis of clastic texture.

The lithologic content of the Illinoian gumbotil is of the same character as that of the Nebraskan and Kansan gumbotils. The lithologic analyses of gumbotils below show a high percentage of siliceous pebbles which is in agreement with the interpretation that gumbotil is a residual weathered product of till :

\begin{tabular}{|c|c|c|c|c|}
\hline & $\begin{array}{c}\text { Nebraskan } \\
\text { Gumbotil }\end{array}$ & $\begin{array}{l}\text { Kansan } \\
\text { Gumbotil }\end{array}$ & $\begin{array}{l}\text { Illinoian } \\
\text { Gumbotil }\end{array}$ & $\begin{array}{c}\text { Average of } \\
\text { Gumbotils }\end{array}$ \\
\hline 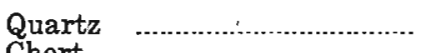 & 36.75 & 48.50 & 45.00 & 43.25 \\
\hline Chert ...................... & 21.75 & 31.80 & 46.00 & 32.92 \\
\hline Quartzite & 20.25 & 7.40 & 0.09 & 9.25 \\
\hline Granite & 8.25 & 7.80 & 2.40 & 6.15 \\
\hline Basalt and Greenstone.......... & 11.25 & 2.90 & 3.30 & 5.82 \\
\hline Feldspar & 1.25 & 1.00 & & .75 \\
\hline Sandstone & & 0.50 & 2.30 & 0.93 \\
\hline Felsite & 0.50 & & 0.10 & 0.20 \\
\hline
\end{tabular}




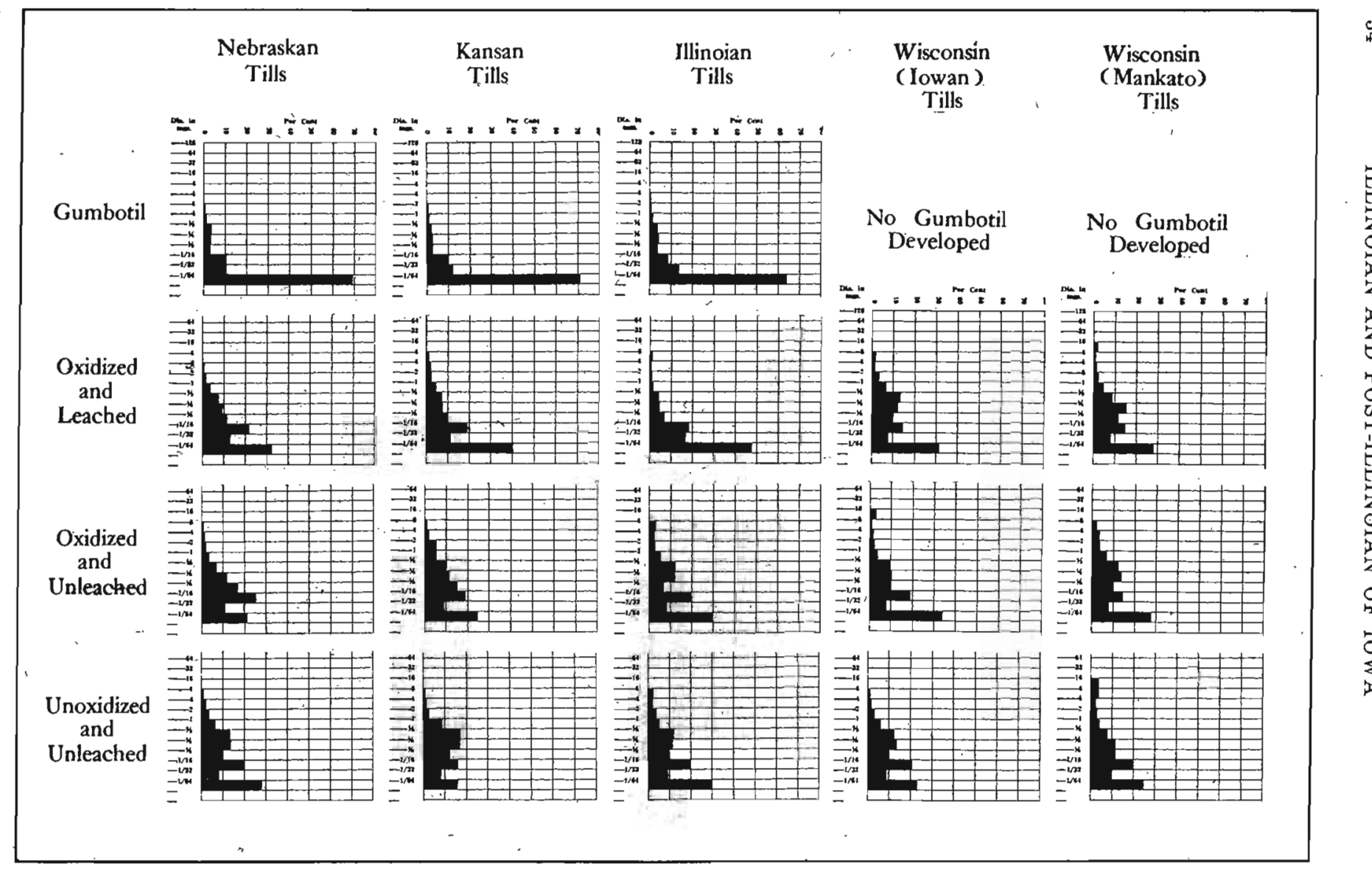

Figure 6. Graphs showing average mechanical analyses of the several tills in lowa. 
It is evident from study of the pebbles that $n \theta$ process of transportation or deposition could alter the rock content so as to increase the percentage of rocks resistant to ordinary processes of weathering, to lower the percentage of rocks which are composed of minerals which weather easily, and to remove almost all of the country rocks which constitute a high percentage of the unaltered till. Chemical weathering of the till is the only process by which this can be explained fully.

The shapes of the grains from the size grades between $1 / 8$ and 1 millimeter in diameter were determined from a study of samples of both gumbotil and unleached and unoxidized till, (fig. 7). Previous studies of materials between 2-4, 4-8, and 8-16 millimeters in diameter have been made by Kay and Apfel. Their results are comparable to those of figure 7 but not so distinct since the size grades used would develop some angularity by disruption from larger dimensions. In studying the size grades between $1 / 8$ and 1 millimeter in dimension, most of the grains. used were siliceous or mineral grains which did not show good cleavage. The difference in shape between grains from the gumbotil and the unoxidized and unleached till is almost entirely due to the chemical solution of the thin edges which were more readily attacked by the weathering agents.

The Illinoian gumbotil was developed to an average thickness considerably less than that of the two older gumbotils. The average of 13 sections which seem to include the entire gumbotil phase is 3.8 feet, with a maximum thickness of 5 feet. This thickness contrasts noticeably with the thicknesses of the Nebraskan and Kansan gumbotils which have average thicknesses of 8 to 9 feet and

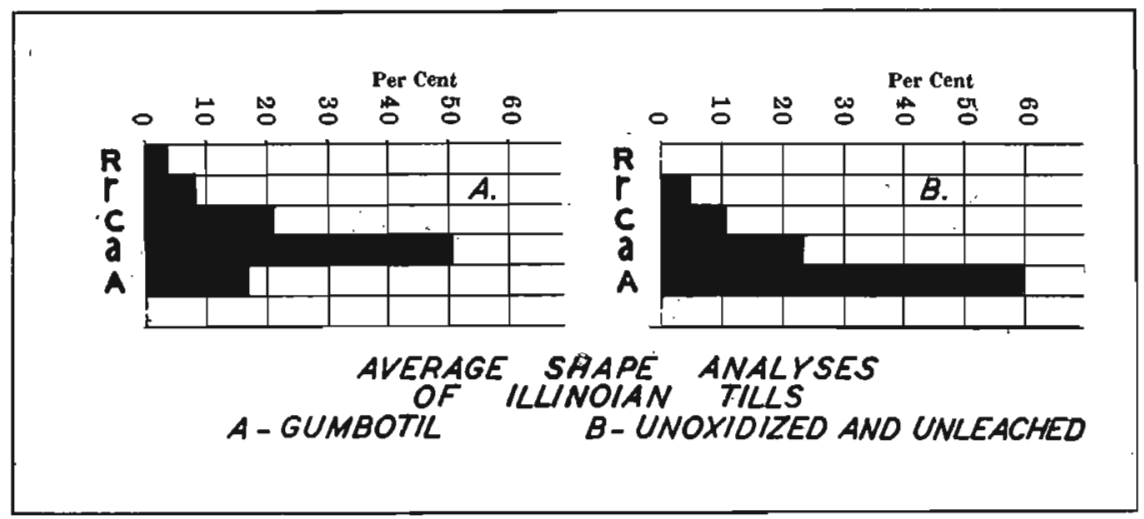

Figure 7. Graphs showing average shape and analyges of Illinoian gumbotil and unoxidized and unleached Illinoinn till. 
11 to 12 feet, respectively. This variation in thickness in the three gumbotils may be used as an aid in till differentiation in sections where the various drift phases appear to be complete. This criterion is especially indicative in isolated sections which topographically might be either Kansan or Illinoian. Figure 8 shows locations of some exposures of Kansan and Illinoian gumbotil in eastern Iowa.

\section{Oxidized and Leached Illinoian Till}

The oxidized and leached phase of the lllinoian till lies immediately below the Illinoian gumbotil, and blends into the gumbotil in such an intimate gradation that it is impractical to attempt to establish a sharp line of demarcation between the two phases, though they differ in their physical characteristics in several important particulars.

The color of the oxidized and leached phase is generally a light brownish yellow, appearing upon close inspection to be a mixture of light-gray and light-buff colors in areas of from 1 or 2 millimeters to several centimeters in diameter. The gray is around the root tubules and where organic materials appear to have been present and in the transition zone where interfingering of the overlying gumbotil produces a lighter hue. There are some ocherous concretionary centers which are rather sharply bounded. These may be the sites of calcareous pebbles which have disintegrated due to leaching.

The downward protuberances of the gumbotil into the transitional zone are seen to be restricted to the smaller joint planes and the vicinity of root tubules, with the larger, and more open joints being stained a darker brown by iron. These areas may be distinguished from the more typical buff color of the oxidized and leached phase as a whole.

The mass texture of the oxidized and leached phase as compared to the gumbotil is distinct, but not so easily discerned as the color differences. It lacks the very characteristic sticky and plastic character of all wet gumbotils and does not have the minute starchy jointing so prevalent in gumbotil. The joints are spaced several centimeters apart and are not prominent if more closely spaced. The coarseness of the jointing is more marked near the base of the phase; the fine polyhedral pattern of gumbotil being restricted to the transitional zone. As a whole, this phase of the till is looser and more heterogeneous in mass texture than is the Illinoian gumbotil, 


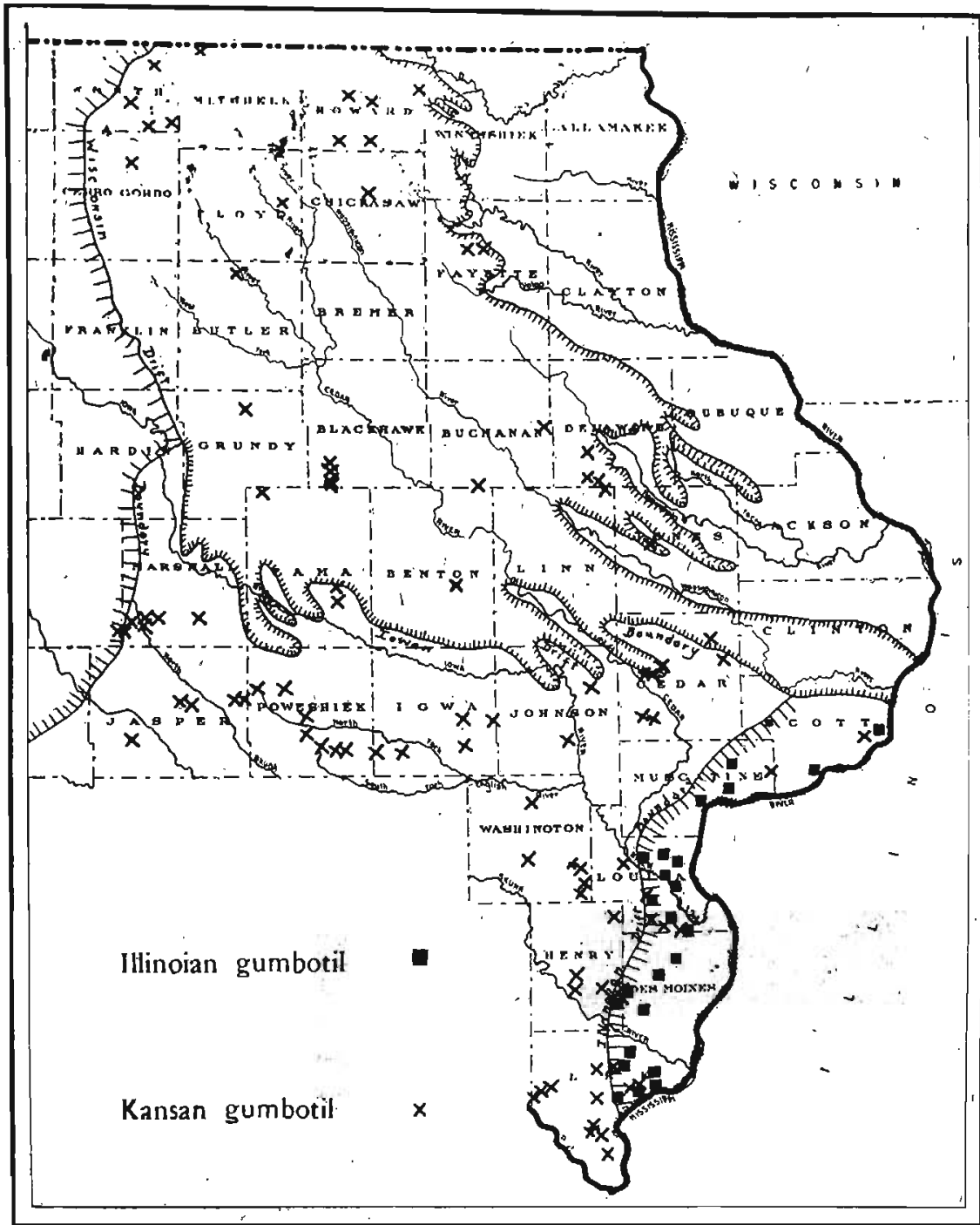

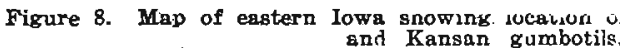

a feature reflecting the greater sandiness and coarseness of the aggregate of the oxidized and leached phase.

The clastic texture of the oxidized and leached till is coarser than that of the gumbotil. The average of the mechanical analyses shows the maximum size grade finer than 1/64 millimeter in diameter, but, in general, this percentage is not as great as in the 
Illinoian gumbotil (fig. 6). This lower percentage is due to the less complete disintegration by weathering of the coarser size grades than is found in the gumbotil.

The same variations as observed in the clastic texture of the different samples of gumbotil are present in the oxidized and leached till. The analysis of a sample of normal till would be much like the average of figure 6 , but sandy till would show a distinct increase in the coarser size grades. Other analyses might show even more of the coarser material than of any intermediate grade between that and the fine.

The lithology of the Illinoian oxidized and leached till is represented by two analyses made by A. H. Dewey. One of the analyses is of pebbles from till below gumbotil and the other is from the till where the gumbotil has been eroded.

PEBBLE ANALYSIS OF ILLINOIAN TILLS

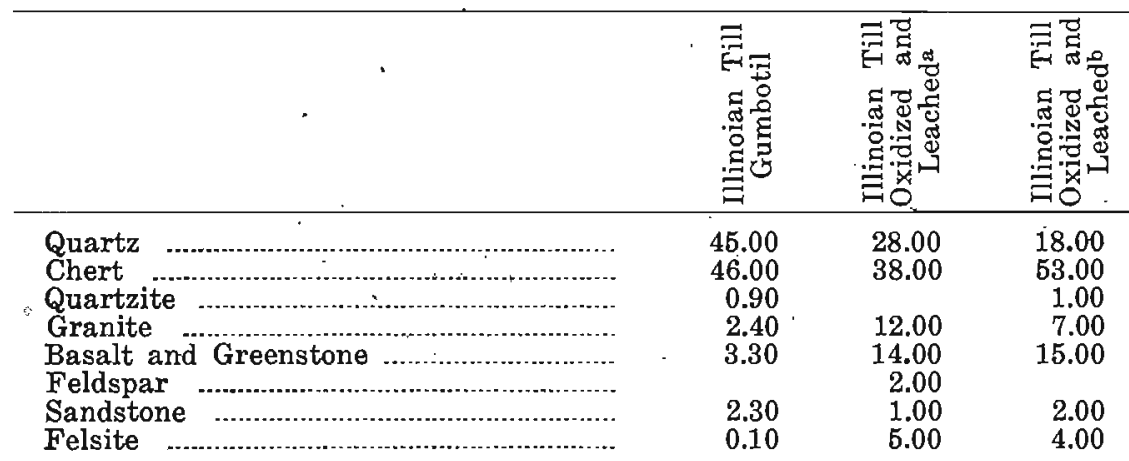

a-Oxidized and leached till where gumbotil has been removed.

$\mathrm{b}-$ Oxidized and leached till below gumbotil.

These analyses, as would be anticipated, are very similar. They contrast with analyses of the gumbotil in that they contain a lower percentage of siliceous material and a greater percentage of other rocks, such as granite and basalt. They are similar to the gumbotil in that their maximum percentage is of siliceous and less soluble material. The presence of granites, basalts, etc., indicates that the weathering processes have not reduced the till to the stage of disintegration found in gumbotil. In many of these rocks, chiefly ferromagnesian rocks, there is an alteration by weathering at the surface along cracks, cleavage planes, etc. The schists are weakened so that they may be easily crumbled.

Shape analyses of this material do not show enough differences between this and the gumbotil to be of value. The differences are 
not more than might be found within the samples of oxidized and leached till themselves.

The oxidized and leached phase of the Illinoian till shows considerable variation in the sections where the overlying gumbotil permits measurements. The average depth is about 3 feet, with a maximum of 7 feet. This is slightly greater than the depth of leaching below the Nebraskan gumbotil, but less than the Kansan oxidized and leached phase. The Illinois Geological Survey has found this phase in Illinois to average 1 to $1 \frac{1}{2}$ feet in thickness.

\section{Oxidized and Unleached Illinoian Till}

The change in the till phases from oxidized and leached to oxidized and unleached is to be seen in a transition zone of varying thickness in which blocks of unleached till are bounded by major joint planes along which leaching has occurred. The line of response to acid may thus be found high, where blocks of till have not been latticed with joints to facilitate leaching, or low where prominent jointing has permitted flow of solutions. The depth of variation may be a foot or more.

The lower limits of the oxidized and unleached till are found in an even greater transitional zone in which massive blocks of the bluish unoxidized and unleached till, several feet in dimensión, are bounded by the brown-stained zones of the joint planes. Especially in the upper part of the transition zone this downward penetration of oxidation along joint surfaces has produced such promiscuous interphasing that the result appears similar to the physical incorporation of masses of a lower, older material into an overriding, younger deposit. However, the gradual lessening of oxidation outward from the joint surfaces in the deeper parts of the transition zone, which finally narrows away, is convincing evidence of the true relationship. This zone in which there is greater or less interphasing may be many feet thick in sections great enough to permit unoxidized and unleached till to yet remain.

Just below the base of the upper transitional zone, between the oxidized and leached and the oxidized and unleached phases, there may be an indefinite thickness of till bearing secondary calcium carbonate concretions leached from the overlying noncalcareous phase. This enrichment normally forms nodules in the till for several feet below the base of the leached phase, and nodules, or an encrustment of white limy powder, along the joint surfaces to still greater depths. 
The color of the oxidized and unleached phase is darker in tone than the leached till above. Along the joints there is commonly a crust of dark-brown, almost black, iron oxide, and this color penetrates the till for a short distance along the joints. Within the till are concretionary centers, 5 to 15 millimeters in diameter, with iron oxide the cementing material. From the center of each concretionary area the color grades outward to the lighter-buff color of the till.

The mass texture of the oxidized and unleached phase shows an increasing coarseness over the phases above. Below. the transitional zone occurring at the top of this phase, the secondary joints become more insignificant, with the primary jointing being from 1 to 2 or 3 feet apart in the lower portions. The secondary or finer joints are spaced 5 to 10 centimeters apart and are fairly smooth and'regular. The angles between the joints are usually somewhat greater or less than right angles. This reduction in the number and proximity of small joints is reflected in the increasing hardness of the till as it changes into the fresh, unaltered phase below which breaks into small pieces with conchoidal fracture due to the lack of preexistent fracture lines. Digging becomes increasingly difficult, a pick being necessary while in the oxidized and leached phase, and in the upper part of the oxidized and unleached phase a spade is often sufficient:

The clastic texture of the Illinoian oxidized and unleached till is strikingly different from that of either the oxidized and leached till or the gumbotil. A comparison of the histograms of the average mechanical analyses of the oxidized and unleached till with those of the oxidized and leached, and the gumbotil in figure 6, page 34, shows a greater decrease in the percentage. of the size grade finer than 1/64 millimeter in diameter. The size grade between 1/64 and 1/32 millimeter in diameter shows a distinct decrease, the percentage generally lower than 10 percent. Instead of a general decrease in percentages with increase in size grades above $1 / 64$ millimeters in diameter, there are two or three secondary maximums. Aside from the irregularities given, the only other difference from the analyses of the gumbotil and oxidized and leached till is the coarseness resulting from the lack of disruption by chemical weathering.

The most striking difference between the oxidized and unleached till and the gumbotil and oxidized and leached till is in the lithology. Although the gumbotil and oxidized and leached till contain a high percentage of siliceous material, a low percentage of granites and 
other such coarse crystallines, and a total absence of limestone, the oxidized and unleached till contains a high percentage of limestone, an increase in the percentage of granites and other such crystallines, and likewise a comparable decrease in the amount of siliceous material.

The abundance of such rocks as limestone, dolomite, granite, and basalt in the till indicates that the till has undergone very little chemical change. As further substantiation of the lack of chemical weathering, many of the easily soluble rocks such as limestone and dolomite still show scratches and striations made on their surfaces during transportation by the glacier.

\section{Unoxidized and Unleached Mlinoian Till}

The basal phase of the lllinoian till is unoxidized and unleached, 'differing as a whole, from the phase above only in oxidation. Mineralogically and texturally, the two phases are much the same. Exposures of the fresh, unaltered bluish-gray till are uncommon, due partly to the rapidity with which the processes of oxidation attack a fresh surface and partly because in the characteristically thin Illinoian till, oxidation has penetrated to the base of the till in many areas. Thus, the Kansan gumbotil, or older surface, may be overlain by Illinoian oxidized and unleached till rather than unoxidized and unleached till.

The basal till phase is typically dark gray when dry, with a slightly bluish tint when wet. Within the mass are specks of brown color, and along some of the major joints are thin films of coloring matter. The drab color of the fresh till does not seem to be so much a reflection of the color of the bedrock in the general region as a product of the mass blending of all kinds and colors of rocks, and is therefore a somewhat standardized color for all fresh tills except in those localities where the local bedrock component of the till is abnormally high, as may be seen in a black shale locality in northwestern Iowa.

The mass texture of the unoxidized and unleached till is similar to the oxidized and unleached phase except for the concretionary zone in the latter. Major jointing is infrequent. The finer joint pattern is poorly developed, the joint surfaces being widely spaced, relative to the other phase, commonly being 10 to 20 centimeters apart.' The material is gritty with considerable content of small pebbles, and where joint planes intersect these pebbles, the pebble 
impression is left sharply molded in one side when the till is separated along the plane.

The clastic texture of the unoxidized and unleached till is not distinctly different from that of the oxidized and unleached till. The average mechanical analyses of figure 6 , page 34 , show no greater variation from the oxidized and unleached till than would be present within the different samples of the unoxidized and unleached till. The slight difference seems to show a further decrease in the percentage of the material below 1/64 millimeter in diameter. However, the increase is not in the coarser grades, but in those grades between $1 / 8$ and $1 / 2$ millimeter in diameter.

The lithology of unoxidized and unleached till is almost the same. as that of the oxidized and unleached till, for the only change which the oxidized and unleached till has undergone is the oxidation of the iron compounds which would not alter the rock content.

The percentage of rounding of the size grades between $1 / 4$ and 2 millimeters in diameter is shown in figure 7, page 35. The grains studied were essentially of siliceous character and would be comparable to those studied from the gumbotil samples. This type of material was used since the chemical weathering would be recorded in rounding of the grains rather than disruption along cleavage planes or contact surfaces between mineral grains in such rocks as granites. The graph representing an average of five analyses shows almost 60 percent in the gumbotil. Likewise, the gumbotil shows more than twice the percentage of subangular and as much in the curvilinear as shown in the subangular grade of the unoxidized and unleached till. This shows the changes undergone in the rounding of sand grains during the formation of gumbotil.

\section{THICKNESS OF THE ILLINOIAN DRIFT}

Yarmouth interglacial time afforded abundant opportunity for erosion of the Kansan gumbotil plain, for the clearing out of some pre-Kansan valleys and for the forming. of new drainage lines. Secondary courses and systems cut back into the gumbotil plain and must have become quite extensive before the Illinoian glacial advance. Chief among these streams in the region of present study were the Wapsipinicon, the Cedar-Iowa, and the Skunk. Because the Illinoian ice in Iowa was so near the limit of its extent, it probably was relatively thin and did not carry such a load of drift as it had farther east.

The outcrops in Lee County seem to show the thinnest and also 
the thickest sections of Illinoian till that have been found in the state. The exposure in sec. 35 , Washington Township, (T. 68 N., R. 4 W.), a short distance northeast of Fort Madison, shows only 2 feet of till, all leached, between Kansan gumbotil below and Illinoian gumbotil above. The upper gumbotil is 4 feet thick.

On the other hand, the gully in the southeast corner of sec. 33, (T. 68 N., R. 4 W.), not much over a mile west of the previous one, shows evidences of a filling of Illinoian drift that may be over 100 feet thick. Dark unaltered till seems to extend downward nearly to the river level, about 170 feet from the upland. Of course, the possibility must be held in mind that some, perhaps much, of this is Kansan or older drift.

Between the extremes represented by these two sections are a number that probably approach nearer the average thickness of the Illinoian till. The ravine up which State highway 22 ascends from valley to upland near Davenport shows a thickness of 36 feet of till and gumbotil above the Kansan. The gully southeast of Grandview, in sec. 26, Grandview Township, (T. 75 N., R. 3 W.), Louisa County, has cut through at least 25 feet of Illinoian, apparently without reaching the base. The exposures near the Iowa River in sec. 4, Grandview Township, (T. 74 N., R. 3 W.), include 39 feet of unleached Illinoian till beneath 6 feet of till and gumbotil. Finally, the creekside exposure just south of New London shows 40 feet of Illinoian till well-delimited by the Kansan and Illinoian gumbotils. The sum of the evidence presented by the various outcroppings showing the entire thickness of the Illinoian till seems to point to a general estimate of 30 feet for the thickness of the Illinoian drift in Iowa. This is in agreement with estimates made in Illinois where this drift forms the surface cover.

These facts show that the Illinoian drift, while not so thick in the Iowa region as the Kansan or the Nebraskan, is nevertheless a drift sheet of large proportions. The truth of this statement is especially striking when we remember that the extreme western limit of this drift and of its parent glacier is about 1600 miles from the eastern source of the ice. A very copious supply of material and a tremendous impelling power must be conceived as having been behind the long reach of "the Illinoian glacier. It must be kept in mind, of course, that very little, if any, of the mixture of rock and clay that make up the Illinoian drift of Iowa originated in the Labrador peninsula. Most of it doubtless came from west of the Indiana-Illinois state line, some of it perhaps brought there by 
the Kansan or the Nebraskan ice sheets as suggested before. The Illinoian till of western Illinois is much less calcareous where it overlies Pennsylvanian shales than where it rests on the Devonian limestones of the Rock Island region. This affords a concrete suggestion of the relatively short distance that most of the drift has traveled. 


\section{CHAPTER II \\ THE CENTRALIAN EPOCH (SERIES) THE SANGAMON INTERGLACIAL AGE (STAGE)}

The Sangamon record

Descriptions of Sangamon features

Illinoian gumbotil and related weathered zones

Sangamon sands and gravels

Weathered IIIinoian upland gravels

Late Sangamon loess

Sangamon peat deposits and soils

Lake Calvin

Sangamon erosion

Comparitive dissection of the Illinoian and Kansan drift plains

Record of life in the Sangamon

The Loveland formation

History of investigations of the Loveland formation

Loveland loess

Sections of Loveland loess

Laboratory studies of Loveland loess

Mechanical analyses

Mineral analyses

Loveland sands and gravels

Volcanic ash in the Loveland formation

\section{THE SANGAMON RECORD}

The Sangamon interglacial age (stage) followed the third continental glacier of the Pleistocene, the Illinoian. The Sangamon was preceded by two earlier interglacial ages, the Aftonian, which followed the Nebraskan ice age, and the Yarmouth, which followed the Kansan glaciation. The name Sangamon was used first by. A. $H$. Worthen ${ }^{11}$ for a soil zone lying between Illinoian drift and overlying Iowan loess, which he described in a report on Sangamon County, Illinois, written in 1873 . The present usage of the term Sangamon to denote the interglacial age between Illinoian and Iowan glacial ages was introduced by Leverett ${ }^{12}$ in 1898 . Since the original description of this soil zone as representative of an interglacial age following the Ilinoian glaciation, the physical record of this interval has become much better known by the recognition and investigation of weathered tills, weathered sands and gravels, late Sangamon loess, peat beds, and Lake Calvin.

\footnotetext{
uWorthen, A. H., Geology of Sangamon County: Illinois Geol. Survey, vol. 5, pp. 306-819,1878. 12Leverett, Frank, The weathered zone, (Sangamon), between the Iowan loess and nlinoian till sheet: Jour. Geologg, vol. 6, pp. 171-181, 1898:
} 


\section{DESCRIPTIONS OF SANGAMON FEATURES}

\section{Illinoian Gumbotil and Related Weathered Zones}

Following the deposition of the Illinoian till, weathering agents attacked the till and related deposits. Finally, where the topographic and other conditions were favorable, gumbotil was developed and beneath the gumbotil, an oxidized and leached zone and an oxidized and unleached zone were formed. The various steps in the formation of gumbotil and underlying weathered zones from fresh till are described on pages 31 to 41 . The average thickness of Illinoian gumbotil is about 3 feet 6 inches to 4 feet.

The Illinoian gumbotil is the youngest of the three gumbotils developed from tills : namely, the Nebraskan gumbotil, the Kansan gumbotil, and the Illinoian gumbotil. The Illinoian gumbotil plain has not been dissected to the degree that the Nebraskan and Kansan gumbotil plains have been affected by erosion. The Illinoian upland is today a region of widespread undissected topography with most of its uneroded area in the position of the original Illinoian ground moraine plain. Late in the Sangamon interglacial age, after the Illinoian gumbotil and related materials had undergone in places considerable erosion, a loess; the late Sangamon loess, was deposited. This loess was weathered somewhat before the deposition of the oldest deposits of Wisconsin age.

\section{Sangamon Sands and Gravels}

Sands and gravels associated in age with the Sangamon interval are of several types and need not necessarily be contemporaneous in deposition. As in the case of the two older drift sheets, the Nebraskan and the Kansan, sands and gravels of glacial age were formed as pockets or lenses within or on the Illinoian drift, with subsequent weathering of these gravels during Sangamon time. Beyond the ice front, gravels were deposited as 'outwash and terrace gravels, related in time of deposition to the Illinoian glacier but weathered by processes active during the long interglacial period which followed. Gravels are found which are genetically related to the interglacialsage, having their formation dependent upon the erosion of drift or bedrock materials during the interglacial age.

\section{Weathered Illinoian Upland Gravels}

During the deposition of Illinoian drift, masses of gravels were laid down in places as pockets or irregularly shaped deposits either 
within or upon the Illinoian till, being glacial in origin and contemporaneous in age with the till. Where these deposits lie upon or within the till, but near enough to the surface to be affected by the agencies of weathering, they were partially disintegrated and decomposed during Sangamon time.

Only one good example of such gravel is known to be available for study in Iowa. This exposure has been described by Kay and Miller. ${ }^{13}$ It is in the $E^{1 / 2}$ sec. 23 , Bloomington Township, (T. 77 N., R. 2 W.), Muscatine County, near the Illinoian upland along the west side of the valley of Mad Creek.

The gravel here is an irregular pocket, exposed at the Illinoian drift surface, with a maximum depth of 35 feet. The gravel is iron-stained, particularly in the upper portions. Leaching is irregular in depth but averages about 7 feet in that part of the pit where minimum erosion has taken place. Variation in the lime content of the unaltered material, the irregularity of cover, and the noncalcareous sand which overlies, the gravel in places contribute to the uncertainty of the depth of leaching of this upland deposit. An exposure of Illinoian upland gravel near the village of Sparta in Illinois is considered to be representative of the depth of leaching of upland gravels during Sangamon time, a depth of about 12 feet.

The bedding of the gravel ranges from horizontal to dips as high as 50 degrees, with the dipping in no predominant direction. Figure $9 \mathrm{a}$ is a diagrammatic representation of the size grade percentages of an average sample, from the deposit. Figure $9 \mathrm{~b}$ represents the lithologic percentages of the gravel between 16 and 32 millimeters in diameter.

\section{Late Sangaimon Loess}

Within the Illinoian drift area there are, in many places, two loesses on the Illinoian gumbotil and on eroded surfaces of Illinoian drift. The younger of these two loesses is the Peorian loess; the older loess has been named in Illinois the late Sangamon loess. In Iowa this older loess has been correlated by Kay' ${ }^{14}$ with the widespread Loveland loess of western Iowa, which is later than Kansan gumbotil erosion and is pre-Iowan in age. Leverett, ${ }^{15}$ however, correlates the Loveland loess of western Iowa with pre-Illinoian

\footnotetext{
${ }^{2}$ Kay, G. F. and Miller, P. T., The Pleistocene gravels of Iowa: Iowa Geol. Survey, vol. 37, pp. 88-92, 1941 .

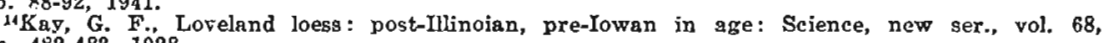
pp. $482-483,1928$

p. 16 Leverett, Frank, Loveland loess: pre-Ininoian, pre-Iowan in age: Science, new ser., vol. 69, pp. 551-552, 1929 .
} 


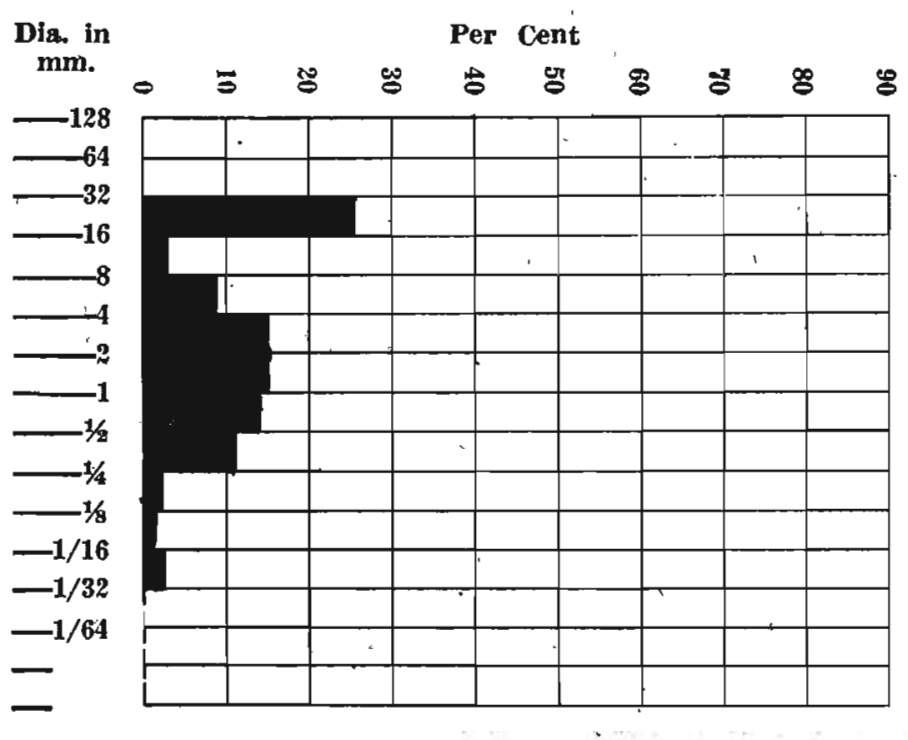

a

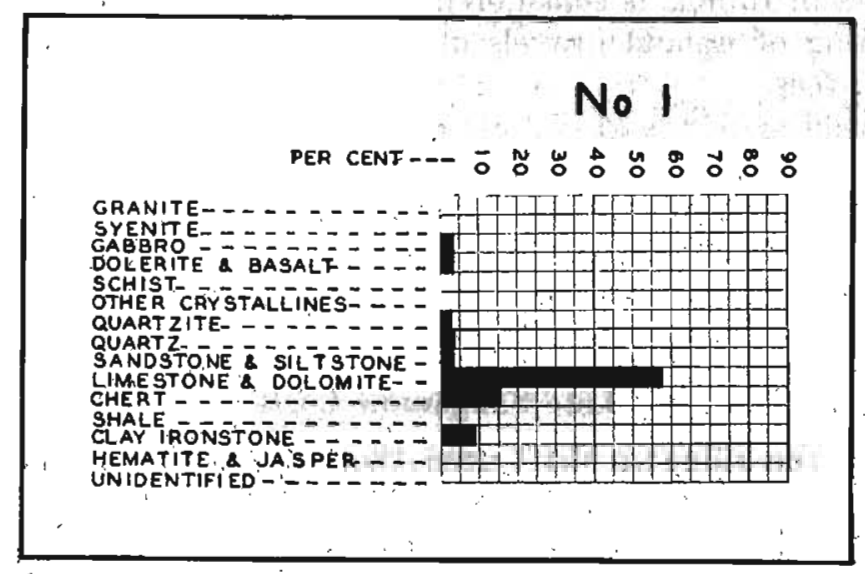

b

Figure 9. Graphs showing (a), mechanical analygis and (b), lithologic analysis of Illinoian upland, gravel.

loess and questions the existence of a post-Illinoian, pre-Peorian loess. But in recent years this older loess on the lilinoian has been mapped widely by members of the Illinois and Iowa Geological Surveys. Although the Loveland loess of western, central, and southern Iowa outside the limits of the Illinoian area appears to 
be a single formation which was deposited in post-Illinoian, preIowan time, Kay ${ }^{16}$ has stated that in reality its lower part may be pre-Illinoian in age, and only its upper part post-Illinoian; and it may be that a part of the Loveland loess in western Iowa and adjacent areas was deposited during the Illinoian glacial age.

In the Iowan drift area of northeastern Iowa, Loveland loess

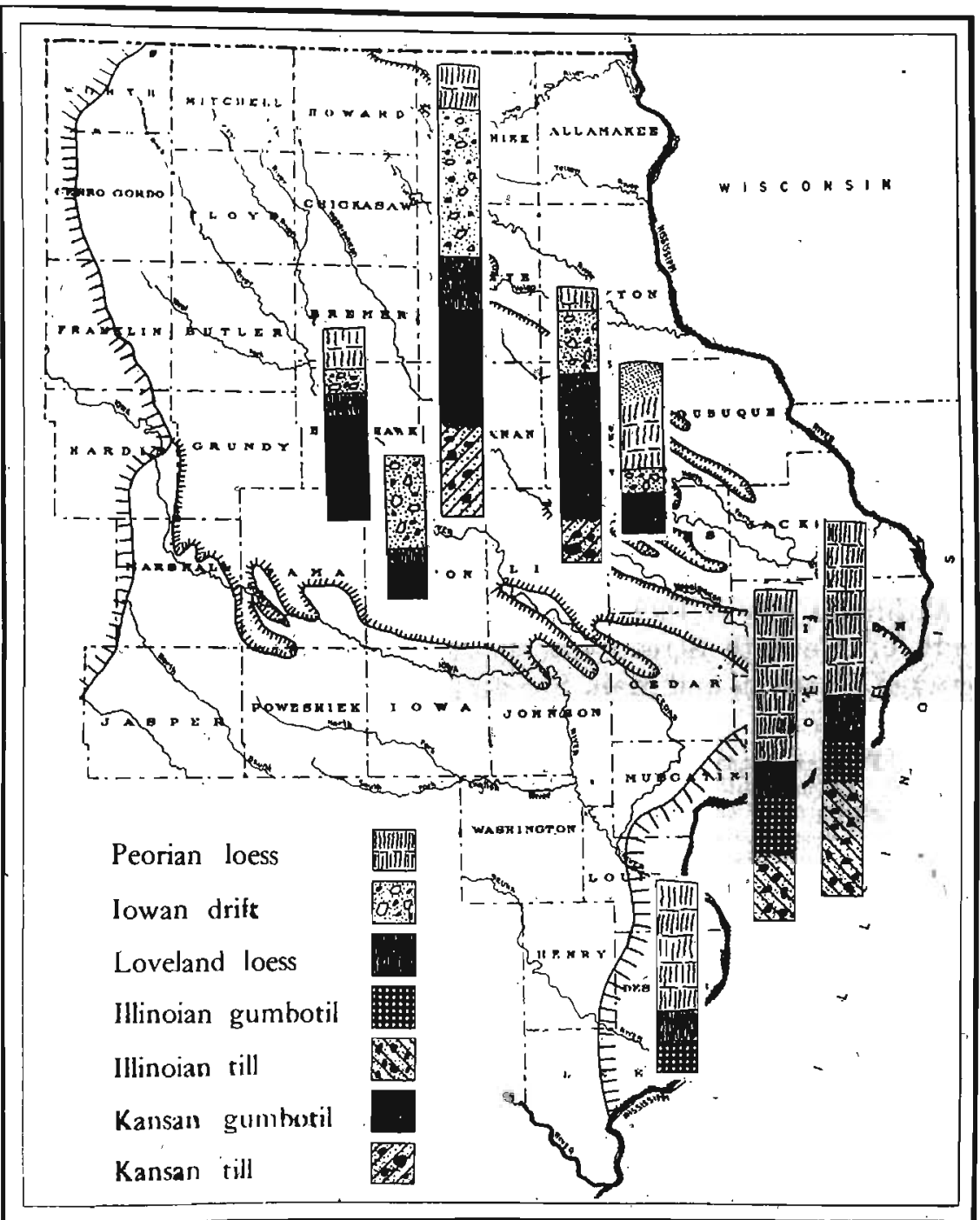

Figure 10. Diagram showing stratigraphic relationships of Loveland loess in eastern Iowa.

${ }^{10 \mathrm{Kay}, ~ G}$. F., Significance of post-Ilinoian, pre-Iowan loess: Science, new ser., vol. 70, pp. 259-260, 1929 . 
is post-Kansan gumbotil erosion, pre-Iowan in age. Here the late Sangamon, or Loveland loess is overlain by calcareous Iowan till. In the Illinoian area of southeastern Iowa, the Loveland loess is post-lllinoian gumbotil, pre-Peorian loess in age. These relationships are graphically shown in figure 10.

The Loveland loess of the Illinoian drift area in Iowa has now been established by stratigraphic methods as being much younger than the Illinoian glacial drift and older than the Iowan glacial drift; that is, it is late Sangamon in age. The loess was deposited after the development over wide areas, chiefly by chemical weathering, of gumbotil more than 3 feet thick on the Illinoian till. Before the advance of the Iowan drift sheet there was sufficient time for the loess to be leached to a depth of several feet.

Several good exposures of Loveland or late Sangamon loess are found in Scott County. About 1 mile west of Davenport, on State highway 22, in the SE1/4 sec. 31, Rockingham Township, (T. 78 N., R. 3 E.), a road cut shows a succession of Illinoian gumbotil, Loveland loess, and Peorian loess. The gumbotil is 3 feet thick, gray; and typical in character. The Loveland is leached, brown in color, has some secondary calcium carbonate, and is here about $1 \frac{1}{2}$ feet thick. This is overlain locally by 8 feet of Peorian loess, gray below and buff above.

Within the city of Davenport, good sections of Loveland loess are south of Eleventh Street, just south of the high school building between Harrison and Main Streets. Here a section shows:

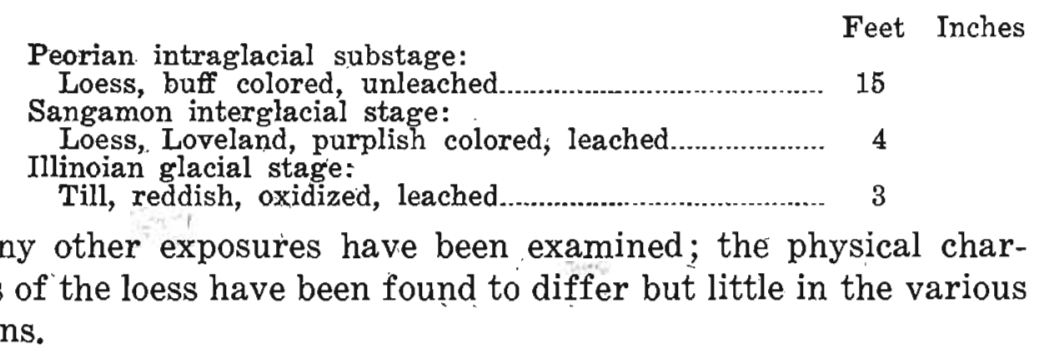

\section{Sangamon Peat Deposits and Soils}

Since the days of Winchell, Chamberlin, and McGee, peat beds have been used by glacial geologists as indicative of interglacial ages. Conditions which permit the slow accumulation of compact vegetal matter in areas protected from erosion are not in themselves criteria of subtropical or even temperate climate, but merely 
indicate favorable burial conditions of vegetal debris over a considerable period of time. It is the study of such deposits in relation to their surrounding materials, their topographic positions, the estimated rate of accumulation, and the climatic environment indicated by the plant fragments and pollen grains which enable the geologist and paleobotanist to interpret the conditions which prevailed during the interglacial age in which the peat was deposited.

The poorly drained topographic conditions which exist following deposition of a glacial drift sheet are ideal for bog and swamp formation, and the accumulation of small isolated areas of peat in the depressions distributed over a fresh till plain is probably far more prevalent than the few peat occurrences known on the older drifts would seem to show. Peat deposits in various stages of formation and burial are widely prevalent over the young, poorly drained Mankato drift, with often as many as four or five distinct peat bogs per square mile. There is little reason to believe that the surface environment of the older drifts including the Illinoian differed essentially either in topography or climate from that which has existed in north-central Iowa since the retreat of the Des Moines lobe.

The best section seen in the Illinoian drift area of Iowa to show Sangamon peat is in the southwest corner of sec. 10, Port Louisa Township, (T. 74 N., R. 3 W.), Louisa County. It is in the northwest valley wall of the Iowa River where a cut has been made along U. S: highway 61 . Here the section is as follows:

Sand, dune-like, white and yellow, little if any calcar-
eous material, some laminations..............................

Here the Loveland loess was deposited in an eroded area, of the Illinoian drift plain and the peat accumulated in an undrained depression on the loess surface. The Illinoian gumbotil elevation about 5 miles to the north, in sec. 26, Grandview Township, (T. 75 N., R. 3 W.), is 650 feet above sea level. The elevation of the peat on the loess is about 600 feet. 
Samples of the peat from this section.were collected by Geo. H. Lane, ${ }^{17}$ and a study of the pollen grains found in the peat at 2 -inch intervals makes possible a climatic and floral interpretation of the conditions prevailing during the closing stages of the Sangamon interglacial age. Percentages of the seven most important pollen types from one of the sections, figured at each 2-inch level in vertical section, are shown in figure 11. Lane's study of pollen types in three different sections through the peat has been summarized as follows:

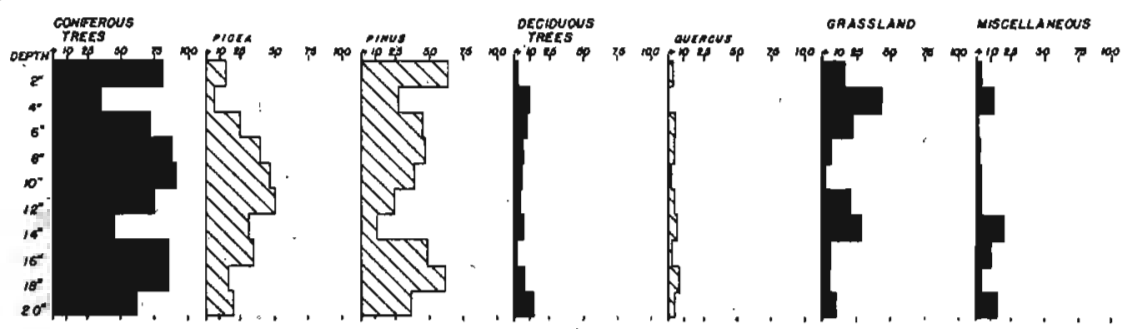

Figure 11. Graph showing pollen percentages in a Sangamon peat bed. (After Geo. H. Lane.)

"It would appear that climatic conditions toward the end of the interglacial interval fluctuated considerably. The uppermost of these peaks of grassland and deciduous tree pollen, (fig. 11), may represent the same sort of brief climatic amelioration as was noted toward the end of the Aftonian interglacial period. The work of Jessen and Milther, (German botanists), in which this feature appears so prominently, was on peat of the last interglacial in Europe which may be contemporaneous with the Sangamon in this country.

"There is, however, no positive evidence that this peat was formed at the very end of interglacial time. The high values of grassland and oak pollen are accompanied by considerable pine and some spruce. These might be interpreted as a mixed oak-pine savannah at some earlier stage in interglacial time. However, the absence of such forms from Voss' long series of materials from nearby stations in Illinois would. lead one to doubt this conclusion. It seems more likely that the Iowan peat is more recent than the nlinois beds and consequently that it developed quite late in Sangamon time."

This interpretation based on floral evidence is in harmony with the stratigraphic position of the peat, for the Loveland loess which is found on the Illinoian drift is a feature of late Sangamon time, having been deposited after the formation and erosion of the Illinoian gumbotil and only enough before the deposition of Iowan or Peorian loess to have acquired a youthful profile of weathering. In point of time, it would seem that the peat bed under discussion is equivalent to the soil zone on the Loveland loess in the Farm Creek section, near Peoria, Illinois.

Another section showing peat on Loveland loess is in Scott

1TLane, G. H., Pollen analyses of interglacial peats of Iowa: Iowa Geol. Survey, rol. 37, pp. $256-260,194 \hat{~}$. 
County. The peat is exposed in a railroad cut of the Chicago, Rock Island and Pacific Railway, just south of the viaduct where highway 22 crossed the railroad just within the western limits of the city of Davenport. This section, which was first described by Pratt, ${ }^{18}$ is as follows:

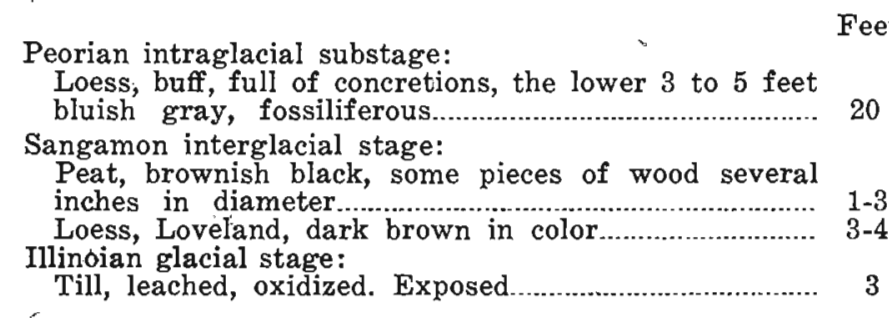

In the description of this section by Pratt at the time of excavation, the dried peat was found to be woody enough to burn, but constituted a very poor fuel. The peat moss Hypnum aduncum was identified as one constituent, along with unspecified coniferous woods.'

A 2-foot bed of peat occurs between Peorian loess and Illinoian till near the northwest corner of the SW1/4 sec. 34, Sweetland Township, (T. 78 N., R. 1 W.), and a thin bed has been seen in the NE $1 / 4$ sec. 15, Bloomington Township, (T. 77 N., R. 2 W.), both of Muscatine County.

The occurrence of Sangamon peat and soil zones in Illinois and southeastern Iowa is discussed by Leverett. ${ }^{10}$ Some of these have attained considerable depth. In general, the formation of Sangamon peat and soil zones has been more restricted in western Illinois and southeastern Iowa than in more easterly areas of the Illinois drift, due to the improved drainage conditions near the valley of the Mississippi River.

Numerous sections of Loveland or late Sangamon loess show the development of a soil zone at the top of the loess, which is usually overlain by calcareous Peorian loess. Such a development is well displayed in an exposure in the NW1/4 sec. 22, Lincoln Township, (T. 79 N., R. 4 E.), Scott County. Here the Loveland loess and soil zone is exposed for about 25 yards along a road cut. The complete section is :

Peorian intraglacial substage:

Feet Inches Loess, buff in color in the upper part, gray and un${ }^{1}$ Pratt, W. H., Report on a geological examination of the section of the bluff recently exposed
by the C. R. I. \& P. R. R. Davenport Acad. Sci. Proc., vol. 1 , pp. 96-99; $1867-1876$.

${ }^{10}$ Leverett, Frank, The llinois glacial lobe: U. S. Geol. Survey Mon. 38, pp. 125-130, 1899. 
leached in the basal part, iron tubules, many concretions; relief.

Feet Inches

Sangamon interglacial stage:

Soil zone, carbonaceous, loess-like, dark brown, leach-

ed but with secondary concretions.................................. 1

Loess, Loveland, leached, brown, laminated, secondary

concretions. Grades into soil above........................ 2-3

The surface of the Loveland loess here is somewhat irregular and this fact probably facilitated the accumulation of carbonaceous soil material. The soil layer is not uniform in thickness.

Outside of the Illinoian drift area, a fine exposure of soil on Loveland loess is at the edge of the Iowan till plain where a deep cut has exposed the two loesses separated by the Loveland soil. This section occurs along the west line of the $\mathrm{NE}^{1 / 4} \mathrm{SE}^{1 / 4}$ sec. 27 , Madison Township, (T. 81 N., R. 7 W.), Johnson County, and is about one-tenth of a mile north of Mid-River Station on the Cedar Rapids and Iowa City Railway. The section is given below:

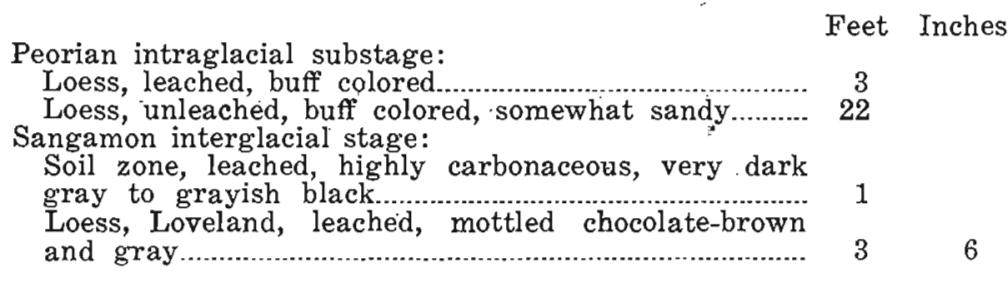

This soil zone is seen for a distance of 150 feet along the base of the slope.

An excellent section exhibiting Sangamon soil directly upon Illinoian gumbotil is along a small ravine in the Illinoian upland near Grandview in Louisa County. It is just east of the road in the $\mathrm{SW} 1 / 4$ sec. 26 , Grandview Township, (T. 75 N., $\bar{R} .3 \mathrm{~W}$.). Here is a fairly complete section of materials representing the Centralian epoch. Reference to the section was made on page 26 of this report. The soil relations are as follows:

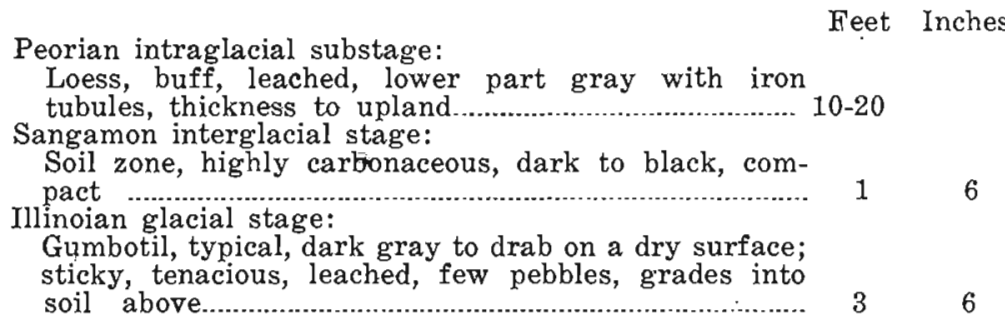

This section was visited by the soil men of the U. S. Department of Agriculture and of the Illinois Soil Survey. The soil zone above 
the Illinoian gumbotil was described by them as typical of the podzolized soil which has a widespread development on the Illinoian gumbotil uplands to the east and north of the Illinoian area in Iowa. It is the "A zone" of the soil profile as interpreted by the Illinoian Geological Survey, being a further development of weathering of the surficial gumbotil materials.

\section{Lake Calvin}

The Lake Calvin basin is an area in southeastern Iowa covering parts of Cedar, Johnson, Muscatine, Washington and Louisa Counties. It is bounded on the southeast by the Illinoiar moraine and drift plain, and elsewhere by the uplands of the Kansan drift. Chiefly, it is an area lying roughly parallel to the Iowa and Cedar Rivers, Iowa City delimiting the main arm along the Iowa River to the north, and Moscow being at the north limit of the main arm along the Cedar River. The basin terminates on the south at the junction of the two rivers, at Columbus Junction, in Louisa County (fig. 12). The lake is thought to have been formed during the Illinoian glacial age by the damming of the Iowa and Cedar Rivers and the displacement of the Mississippi River by Illinoian ice. The pre-Illinoian history of the streams which were affected, the changes which resulted in glacial Lake Calvin and the subsequent drainage of that lake, and the effect of later glaciation on the basin have all been studied in considerable detail.

Leighton ${ }^{20}$ has interpreted the pre-Illinoian history of the Iowa River as follows:

\footnotetext{
"At the time of the encroachment of the Kansan ice-sheet, the topography and drainage were entirely different.from the topography and drainage of the present. A wide valley crossed the southern part of the county, from west to east, and a notable rock divide lay to the northeast. This was covered by the Kansan ice, which, on melting, left drift which filled the low places and leveled off the high ones, producing a flat-lying plain. Upon this the surplus waters of the undrained depressions and surrounding areas sought the lowest outlet and ultimately established Iowa River. The course that the river now has is in general the course that marked the lowest outlet in the beginning.

“. . As Iowa River channeled its course deeper through the drift, it superimposed itself upon the rock-divides in the area of high bedrock. Having established its course it could not avoid them. The drift in the segment upstream and in the segment downstream from high bedrock, being much softer than the rock, offered extraordinarys conditions for variable development of the valley. The resistance of the limestone permitted the river, in the upper segment of drift, to reach grade and to widen the valley by lateral planation while the gorge was being cut. In the segment downstream from bedrock, conditions worked differently, but the result was quite similar. The river cut so much more rapidly in the drift than it did in the rock that it

${ }^{20}$ Leighton, M. M., The Pleistocene history of the Iowa River Valley: Iowa Geol. Survey, vol. 25, pp. 163-167, 1915 .
} 


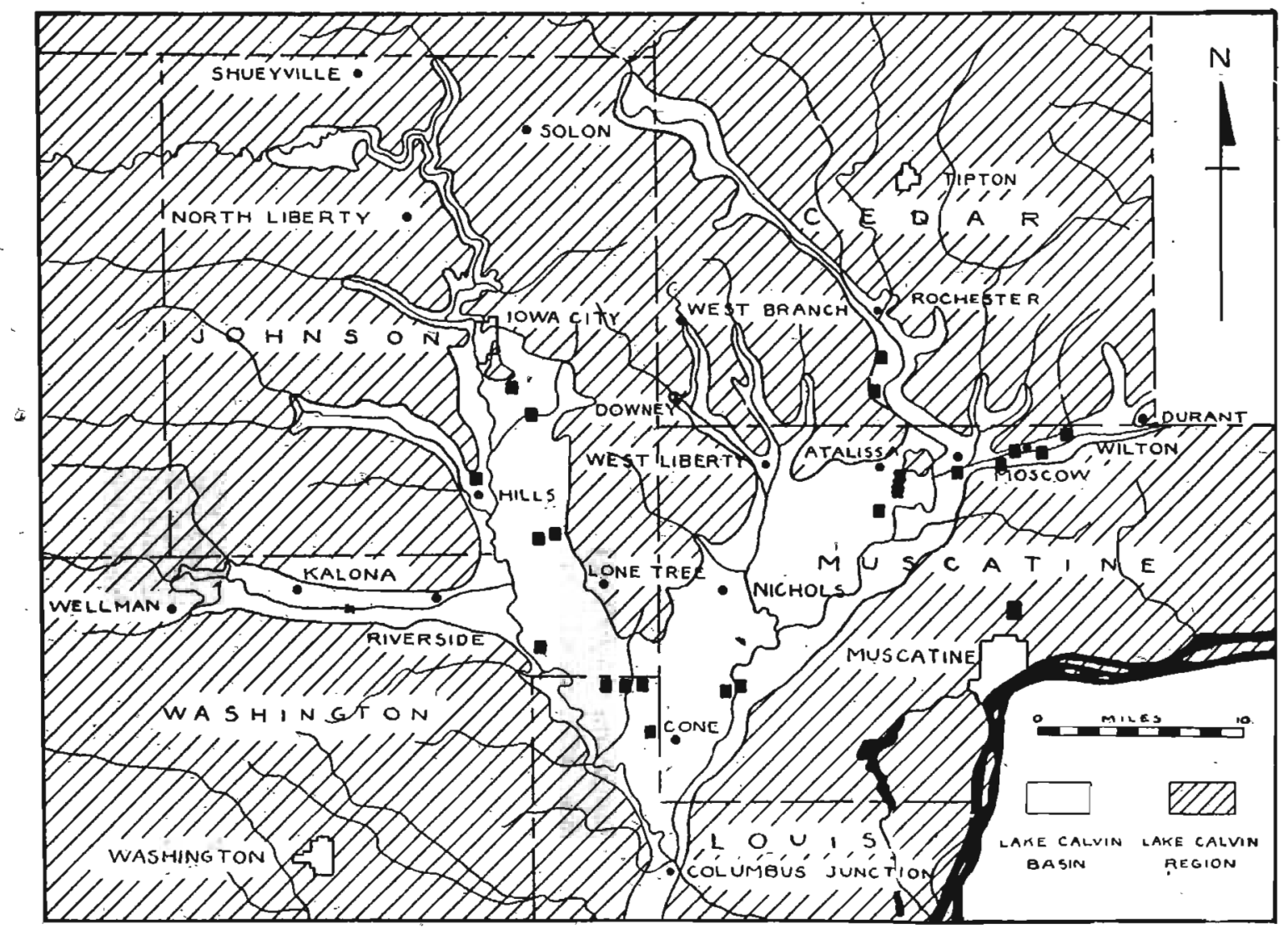

Figure 12. Sketch map of the Lake Calyin area showing the location and extent of the lake.
The sman squares show the location of exposures described by Schoewe. (Map by Schoewe.) 
reached grade sooner and had time to bwiden that segment to an old-age stage of development.

a. Contemporaneously with the carving of the valey tributaries developed. Some of those tributary to the gorge cut considerably into rock whereas those tributary to the wide portions of the valley are cut mainly, if not altogether in drift. The result of the development of all these has been to disseet the original Kansan plain into many valleys and divides, and so completely to change its glacial aspect to an erosional one."

The advent of the Illinoian glacier, which moved a short distance into the state from the east, blocked the lower reaches of the Iowa River, causing its waters to be added to that of the Mississippi and Cedar Rivers until the water level in the ice-dammed basin reached the height of the now abandoned channel which flowed first southwest of the basin and then back to the unfilled channel of the Mississippi somewhere to the south. This channel has been described in detail by Leverett. ${ }^{21}$

That the Cedar River had a pre-Illinoian history similar to that of the Iowa River has been suggested by Norton. ${ }^{22}$ It is thought that the post-Kansan Cedar River followed for a considerable part of its course a bedrock channel which had been carved before the Kansan ice invasion. Norton reviews the evidence in the following paragraph :

"The breadth and sloping sides of the wide reaches of the Cedar are evidences of great age, but in themselves alone these characteristics do not imply a preglacial or pre-Kansan origin. Valleys as broad in southwestern Iowa have been found to be post-Kansan by the geologists who have studied that field. But, while the latter are cut in drift, the former are cut in solid rock in large measure. Taking into consideration both the quantity and the hardness of the material excavated, and, in especial, the fact that the drift lies unconformable on the slopes of rock which form the sides of the valley, the conclusion is inevitable that the wide (bedrock) valleys of the Cedar are at least pre-Kansan in age, and may, perhaps, be even preglacial."

As with the Iowa River, the Illinoian ice front blocked the normal drainage of the Cedar River simultaneously with the shunting of the Mississippi River westward, and these two diverted streams flowed to the southwest along the ice escarpment to the Iowa River Valley where the junction of the ice with the Kansan highlands caused an impounding of the waters to a maximum depth of about 140 feet.

Thus, the waters which filled the blocked pre-Illinoian valleys of the Iowa and Cedar Rivers came from those rivers and the Mississippi with its neighboring tributaries as well as from the glacial waters of the Illinoian ice front.

The duration of this body of water as Lake Calvin, the course or

MLeverett, Frank, The Ilinois glacial lobe: U. S. Geol. Survey Mon. 38, pp. 89-97, 1899.

Norton, W. H., Geology of Cedar County: Iowa Geol. Survey, vol. 11, p. 291, 1901. 
courses of its drainage, and the contemporaneous history of the Mississippi River are problems that have not as yet been satisfactorily solved. The duration and drainage of Lake Calvin, and the position of the Mississippi River during the Sangamon interglacial age would seem to be related. Two somewhat differing views regarding these relationships have been put forward.

Schoewe $\mathrm{e}^{23}$ is of the opinion that Lake Calvin must have lasted until just previous to the Iowan glacial advance. Attention is called to the amount and type of sediment in the lake basin, the gumbotil relations and the contact of the high and low terraces, as evidence of this long duration for the lake. The abandoned channel of Leverett to the south of the basin is suggested as the outlet. This view requires the continued flow of the Mississippi River drainage into its Goose Lake channel inlet, through the filled Lake Calvin basin, and out of the Leverett channel throughout Illinoian glacial and most of Sangamon interglacial time.

Trowbridge, Williams, Frye and Swenson, ${ }^{24}$ and Leverett ${ }^{25}$ are agreed that Lake Calvin was of short duration and that contemporaneously with the retreat of the Illinoian ice to the eastward, the Mississippi River drainage probably reverted to the Illinois River drainageway in west-central Illinois, where there is some evidence of its occupancy during the Yarmouth interval, and that it remained there during Sangamon time. According to their findings, the Mississippi River left the present Illinois River drainage only during the actual accupation of southeastern Iowa and westerm Illinois by the Illinoian ice. This argues for a relatively short duration of the lake, equal only to the time the ice front remained in Iowa. By these authors, Lake Calvin is thought to have been drained by the development of the Iowa-Cedar Valley across the fresh Illinoian drift of southeastern Iowa. As this drainage was controlled both by the Des Moines rapids in the present Mississippi River, and by its distance at that time from the master stream occupying the Illinois River valley, drainage relief on the Illinoian drift plain in Iowa was slight, and gumbotil was able to form very close to the valley walls.

\section{SANGAMON EROSION}

The Illinoian drift plain forms the surface, or lies just beneath.

23Schoewe, W. H., The origin and history of extinct Lake Calvin: Iowa Geol. Survey, vol. 29, pp. 208-218, 1920 .

${ }^{2+}$ Trowbridge, A. C., Williams, A. J., Frye, J. C., and Swenson, F. A., The Pleistocene history of Mississippi River: (Abstract), Iowa Acad. Sci. Proc., vol. 48, p. 296, 1941.

${ }^{25}$ Leverett, Frank, Re-establishment of the Mississippi River after the Illinoian glaciation (Abstract), Geol. Soc. America Bull., vol. 52, p. 1940, 1941; Shifting of the Mississippi River relation to glaciation: Geol. Soc. America Bull., vol. 63, pp. 1283-1298, 1942. 
a variable cover of Peorian and late Sangamon loess, over much of Illinois and an area in the southeast part of Iowa. It is therefore possible to study with little difficulty the post-Illinoian, pre-Peorian, and entire post-Illinoian dissection of the drift sheet. That the stage of erosion found on the Illinoian is distinct from the Kansan till plain dissection, is readily apparent in those areas where the two drift plains are in conjunction.

\section{Comparative Dissection of the Illinoian and Kansas Drift Plains}

In southeastern Iowa, before the Illinoian drift had been determined to extend into Iowa, the difference in the two topographies was noted but not satisfactorily explained. Leverett ${ }^{26}$ says :

\footnotetext{
"Prior to the discovery of the extension of the Illinois lobe into soutneastern Iowa it had been noted by Chamberlin, as well as by the writer, that southern Iowa presents a more eroded appearance than western Illinois and the southeastern counties of Iowa, and the matter was discussed as a remarkable feature. In the district outside the limits of the Illinoian the original drift plain is preserved only in narrow strips along the divides, estimated to comprise scarcely one-fourth of the surface, while in the district covered by the Illinoian drifts the remnants are far more extensive comprising apparently more than half the surface. The branching of drainage lines is also carried to markedly greater maturity in the Kansan than in the Illinoian drift."
}

The Illinoian drift plain is much less dissected than the Kansan drift plain. A reference to the topographic map of a representative area of each of these drift sheets illustrates their differences as to erosion and surface relief. The Illinoian drift plain in Iowa shows comparatively little erosion. Large areas remain as remnants of the featureless plain of original deposition. These are the broad "upland divides." Nearer the drift border, or near master drainage lines, this upland plain aspect is less apparent, but the relatively unreduced stage of the terrain, the youth of the valleys and the lack of well established drainage provinces are convincing evidences of the comparative youthfulness of the region.

In contrast, the characteristic appearance of the Kansan drift surface shows few areas of flat uplands, or tabular divides. Where such areas remain, they are small as compared to the upland plains of the Illinoian drift. The Kansan valleys are broad and moderately deep, with wide, flaring walls merging with remnants of the uplands. The streams in the smaller valleys have not reached grade and they have cut gullied inner valleys. The larger streams have built floodplains and have widened the valley floor in places by lateral planation and meanders have developed. The drainage pat-

${ }^{20}$ Leverett, Frank, The Mlinois zlacial lobe: U. S. Geol. Survey Mon. 38, p. 121, 1899. 
tern is more complete than that of the Illinoian drift, and the graded condition of the larger Kansan streams indicates advanced adjustment of drainage conditions.

The stage of valley cutting on the Illinoian plain during Sangamon time does not seem to be in accord with other evidences of the duration of the Sangamon. The leaching of the gravels and the thickness of gumbotil which formed on the uneroded till uplands indicates a longer interglacial age following the disappearance of the Illinoian ice than the dissection of the till plain alone seems to indicate. A low altitude and slack drainage for the till plain is in keeping with widespread peat and soil accumulation on the drift surface in Illinois.

\section{RECORD OF LIFE IN THE SANGAMON}

Because of the scarcity of fossiliferous deposits which can be definitely ascertained as Sangamon in age, little is known of the fauna and flora in Iowa of this interglacial age. 'Loveland loess, of which the upper part at least is Sangamon in age, is known to be sparsely fossiliferous. ${ }^{27}$ The invertebrate fauna collected from three Loveland loess and silt deposits in Cherokee County in northwestern Iowa have been studied by Cameron. The following lists and interpretations have been taken from unpublished reports by Kay and Cameron.

Two miles west of Larrabee, Cherokee County, a Loveland loess exposure yielded the following mollusks:

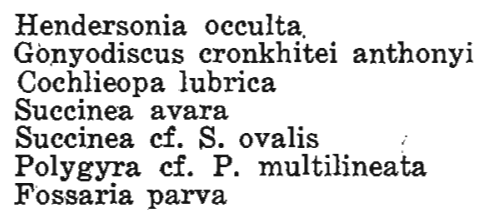

The most indicative of these, Hendersonia occulta, is a snail with habitat on upland slopes and deeply shaded bluffs. Of the 40 specimens collected from the locality, 22 belonged to this species. The fossil assemblage points to loess deposition in deep woods in a temperate climate. A seepy place or small pond probably was present at one time at the place where the collection was made.

From a Loveland silt deposit south of Cherokee in the SW1/4 sec. 1, Pilot Township, (T. 91 N., R. 40 W.), Cherokee County, the following forms were found:

\footnotetext{
${ }^{27}$ Kay, G. F., Recent studies of the Pleistocene in western Iowa: (Abstract), Geol. Soc.
} America Bull,, vol. 35, p. 78, 1924. 


\author{
Pisidium sp. \\ Planorbis sp. \\ Fossaria sp. \\ Pupoides marginatus \\ Succinea avara \\ Gastrocopta armifera \\ Vallonia gracilicosta \\ Hawaii minusculus \\ Pupilla muscorum? \\ Gastrocopta procera
}

This assortment suggests that a mixture of fresh water and terrestrial forms were washed into this deposit. The land forms consist of snails from both forest and prairie habitats.

From a neighboring Loveland section in the SE $1 / 4$ sec. 11, Pilot Township, (T. 91 N., R. 40 W.), Cherokee County, these fossils were collected:

$$
\begin{aligned}
& \text { Gastrocopta armifera } \\
& \text { Pupoides marginatus } \\
& \text { Segmentina armigera } \\
& \text { Euconulus fulvus } \\
& \text { Vallonia gracilicosta } \\
& \text { Hawaii minusculus } \\
& \text { Gastrocopta procera } \\
& \text { Pupilla muscorum? }
\end{aligned}
$$

Here the shells were no doubt. washed into a silt deposit. Both terrestrial and fresh water species with a wide range of habitat and geographic distribution are represented.

Baker has.listed the mollusks collected from a Loveland section in Des Moines County, described earlier by Keyes. ${ }^{28}$ These are:

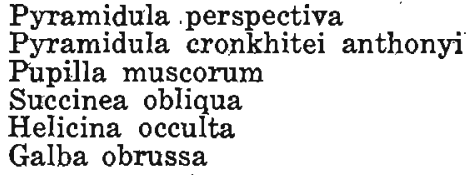

Additional species from this section reported by Leverett ${ }^{29}$ are:

Succinea lineata

Oreohelix iowensis

Several Iowa localities have produced fragmentary vertebrate remains of Sangamon age. From Muscatine County Udden ${ }^{30}$ reported elephant bones from a Sangamon peat deposit in the center of the SW1/4 sec. 12, Sweetland Township, (T. 77 N., R. 1 W.). He also described in detail a partial mastodon or elephant skeleton ${ }^{31}$

\footnotetext{
${ }^{28}$ Baker, C. L., The life of the Pleistocene or Glacial period: Contributions from Mus. of Nat. Hist., No. 7, Univ. of Illinois, pp. 286-287, 1920.

Keyes, C. R., Glacial scorings in Iowa: Iowa Geol. Survey, vol. 8, p. 156, 1895.

${ }^{20}$ Leverett, Frank, The Illinois glacial lobe: U. S. Geol. Survey Mon. 38, p. 169, 1899.

oUdden, J. A., The geology of Muscatine County: Iowa Geol. Survey, vol. 9, p. 350, 1899.

aUdden, J. A., op. cit. p. 852 .
} 
found by Calvin in a clay and sand deposit of Lake Calvin, on Mud Creek, near Wilton. Present views on the age of these deposits may give the fossils a late Illinoian age rather than Sangamon age, as described by Calvin and Udden.

A tusk, teeth and other bones of Elephas primigenius were found in late Sangamon loess along the Chicago, Rock Island and Pacific Railway, west of Davenport. This section has been described earlier in this report, under the heading of Sangamon peat, pages 52 and 53.

Elephant bones, including a lower jaw, were found in Sangamon peat along Otter Creek, near the center of the NW1/4 sec. 25, Morning Sun Township, (T. 73 N., R. 4 W.), Louisa County. ${ }^{32}$ A deer's antler was reported from a neighboring locality, in this same Sangamon horizon.

The Loveland terrace gravels of western Iowa have yielded some vertebrate fossils but Sangamon fossils from the state as a whole are too few and fragmentary to justify any interpretations as to the climate and fauna in general. Perhaps a better basis for generalization on the Sangamon climate is the study of pollens in Sangamon peat made by Lane, and presented on pages 51 and 52 of this report. While the peat deposit studied is thought to represent only the closing stages of the interglacial interval, the sequence of percentages of grassland, oak and other types of pollen suggests a climate in late Sangamon time of coniferous dominance, with the exception of a fluctuation toward the close of the interglacial to a milder, grassland-oak dominance.

Perhaps the best known fossil bearing horizon of Sangamon age in the Upper Mississippi Valley is the richly fossiliferous soil zone at the top of the Loveland loess and below the Peorian loess, in Nebraska. ${ }^{33}$

This zone represents the interval between the deposition of the two loesses, and may have been developed during beginning, Iowan glaciation as well as in late Sangamon time. The vertebrates from this soil horizon include:

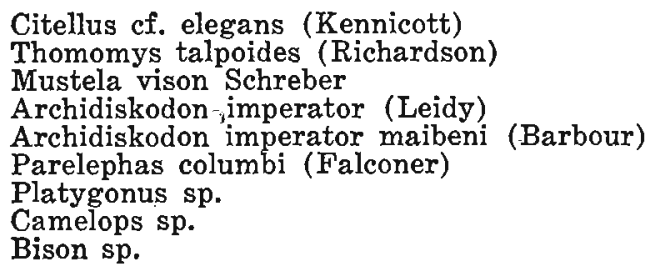

82Udden, J. A., The geology of Louisa County: Iowa Geol. Survey, vol. 11, p. 110, 1901.

sugn. A. L., and Schultz, C. B., The geology and mamma'ian fauna of the Pleistocene of Nebraska: Nebraska State Mus, vol. 1, Bull. 41, pp. 359-360, 1934. 


\section{THE LOVELAND FORMATION}

\section{History of Investigations of the Loveland Formation}

The name Loveland was used first by Shimek ${ }^{34}$ for a deposit in western Iowa. The type section of this formation is at Loveland, Pottawattamie County. In a later paper ${ }^{35}$ 'Shimek described the Loveland deposit as follows:

"A heavy, compact, reddish, (especially on exposure to the air), or sometimes yellowish silt which, when dry, is hard with a tendency to break irito blocks like a joint clay, and, when wet, becomes very tough and sticky; and hence, is sometimes called a gumbo."

By earlier workers this formation was thought to be related to the widespread buff loess of the region, but Shimek believed that it was a fluvioglacial deposit "formed during the melting of the Kansan ice." He considered its distribution to be as general as that of the Kansan drift. Since the original descriptions of the formation, its deposits have been studied and its characteristics and relationships described by geologists of the Iowa Geological Survey. ${ }^{36}$

In a paper, "Recent studies of the Pleistocene in western Iowa," Kay, in 1924, made the following statement with regard to the Loveland of western Iowa:

"In many places it is calcareous and contains calcium carbonate concretions, many of which are from three to six inches in diameter;' a few were seen with greatest diameter more than twelve inches. The Loveland does not show the laminations of water-laid clay, but in places sands and silts of distinct aqueous origin are interstratified with the Loveland clay and in a few places volcanic ash is interbedded with the formation. Moreover, it has the vertical cleavage of loess and stands with similar vertical faces. Although in places fossil shells are present in the Loveland, they are extremely rare in comparison with the numbers of shells which are in the buff loess. The writer believes that the Loveland is not a fluvio-glacial deposit, but a loess distinctly older than the widespread buff loess which overlies the Loveland and which is thought to be chiefly of Peorian age; the Loveland is younger than the Kansan glacial epoch, since it lies upon the maturely eroded surfaces of Kansan till."

In a later paper, "Loveland loess: post-Illinoian, pre-Iowan in age," published in 1928, Kay referred to his statement of 1924 as follows :

\footnotetext{
3Shimek, Bohumil, Aftonian sands and gravels in western Iowa: Geol. Soc. America Bull., vol. 20 , footnote p. 405,1909 .

ashimek, Bohumil, Geology of Harrison and Monona Counties: Iowa Geol. Survey, vol. 20, pp. $371-375,1910$.

${ }^{80 \mathrm{Kay}}$, G. F., Recent studies of the Pleistocene in western Iowa: Geol. Soc. America Bull. vol. 35, pp. 7i-73, 1924; Loveland loess, post-Illinoian, pre-Inwan in age: Science, new ser., vol. 68, pp. 482-483, 1928; Significance of post-Illinoian, pre-Iowan loess : Science,', new ser., vol. 70, pp. 259-260, 1929; with Apfel, E. T.. The pre-llinoian Pleistocene geology of Iowa: Towa Geol. Survey, vol. 34, pp. 277-281, 1929; with Miller, P. T., The Pleistocene gravels of Iowa: Iowa Geol. Survey, vol. 87, pp. 98-118, 1941.

Carman, J. E., Furthur studies on the Pleistocene geology of northwestern Iowa: Iowa Geol. Survey, vol. 35, pp. 49-52, 1931.
} 
"This statement was based upon investigations in a comparatively limited region near the type section, which is on the east slope of the Missouri River valley. The views to be presented in this brief paper are the result of detailed studies of the Loveland formation in widely distributed exposures in Iowa. The characteristics, distribution, origin and age of the deposits of Loveland time in Iowa have been determined and will be described fully in a paper now in preparation.

"In western and northwestern Iowa, at least, the Loveland deposits consist not alone of loess, but also of widespread silts, sands and gravels. While the Loveland silts, sands and gravels were being deposited in valleys, the Loveland loess was accumulating on adjacent slopes and uplands.

"With the writer's knowledge of the characteristics and relationships of the Loveland loess and associated silts, sands and gravels in western Iowa as a background, he examined similar deposits in that part of northwestern Iowa which lies west of the Des Moines lobe of the Wisconsin terminal moraine, where within the last few years Frank Leverett, J. E. Carman and the writer have found evidence of a post-Kansan, pre-Peorian drift which is apparently of the same age as the Iowan drift of northeastern Iowa. Within this Iowan drift area of northwestern Iowa the Loveland loess, silts, sands and gravels are post-Kansan gumbotil erosion, pre-Iowan in age. The Loveland deposits are. younger than the valleys cut in the Kansan drift and are overlain in some places by calcareous Iowan till and in other places by unleached gravels of Iowan age."

In the Iowan drift area of northeastern Iowa and in the Illinoian drift area of southeastern Iowa only the loess phase of the Loveland deposits has been found. In the Iowan drift area of northeastern Iowa this loess is post-Kansan gumbotil erosion, pre-Iowan in age. Here the Loveland loess is overlain by calcareous Iowan till. In the Illinoian area of southeastern Iowa the Loveland loess is postIllinoian gumbotil, pre-Peorian loess in age.

This same relationship of a loess younger than the Illinoian gumbotil and older than Peorian loess was described by Leighton ${ }^{37}$ in a paper published in 1926 describing the Farm Creek Section, east of Peoria, Illinois. He interpreted the older loess to be late Sangamon in age. Regional evidence indicates that the reddish or brownish loess older than the widespread Peorian loess in western and southwestern Iowa, Nebraska, northwestern Missouri, and western Illinois is Loveland loess. Figure 13 is a diagràmmatic representation of the Loveland loess relationships eastward from the type area in western Iowa.

\section{Loveland Loess}

\section{Sections of Loveland Loess}

The late Sangamon loess of the Loveland formation has already been described on pages 47 to 50 .

The Loveland type section is at the village of Loveland, in sec. 3,

9heighton, M. M., A notable type Pleigtocene section: the Farm Creek exposure near Peoria, nlinois : Jour. Geology, vol. 84, pp. 167-174, 1926. 
Rockford Township, (T. 77 N., R. 44 W.), Pottawattamie County. Here the following section is exposed:

Peorian intraglacial stage:

Feet Inches

Loess, fossiliferous

75

Loveland interyal:

Loess, reddish, blocky, vertical joints, pebbly-especial-

ly in lower part calcareous concretions, fossils rare 17

Kansan glacial stage:

Till, oxidized, yellow to chocolate color, breaks into

irregular shapes, small lenses of sand included, many

calcareous concretions in upper part

Till, chiefly unoxidized and unleached, dark to very dark gray when dry, tough.

(Talus)

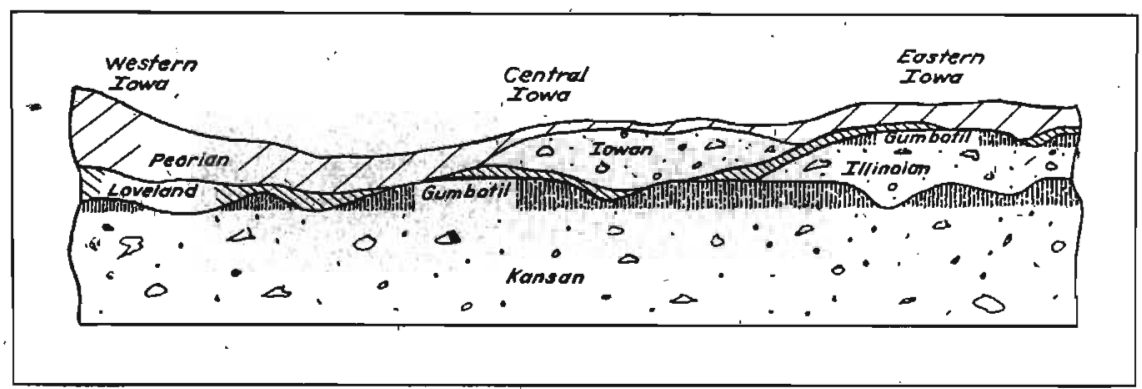

Figure 13. Diagram showing the Loveland loess relationships eastward from the type area in western Iowa.

In the section, it has not been found possible to separate sharply the Loveland loess from overlying Peorian loess, although at several neighboring sections the contact between the two loesses is definite and sharp. Calcareous concretions are well shown in figure 14 which shows a Loveland exposure at Council Bluffs, Iowa.

In a railroad cut in sec. 28 , Garfield Township, (T. 72 N., R. 39 W.), Montgomery County, just west of McPherson Station, a fine section of Loveland loess is exposed. The section is:

Peorian intraglacial substage:

Feet Inches

Loess, typical

25

Loveland interval:

Loess, concretions in lower part, thoroughly leached,

has reddish tinge, pebbles in lower part, some of

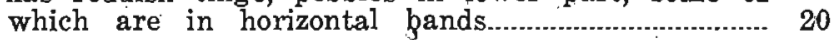

Kansan glacial stage:

Till, oxidized and leached, much red quartzite.

Just east of McPherson, and but a few hundred yards from the exposure above, the Loveland attains the unusual thickness of 30 feet. It shows the typical reddish joint-clay appearance which in 
contact with the buff Peorian is quite noticeable. This region is in rolling loess depositional topography with billowy relief and no tabular divides.

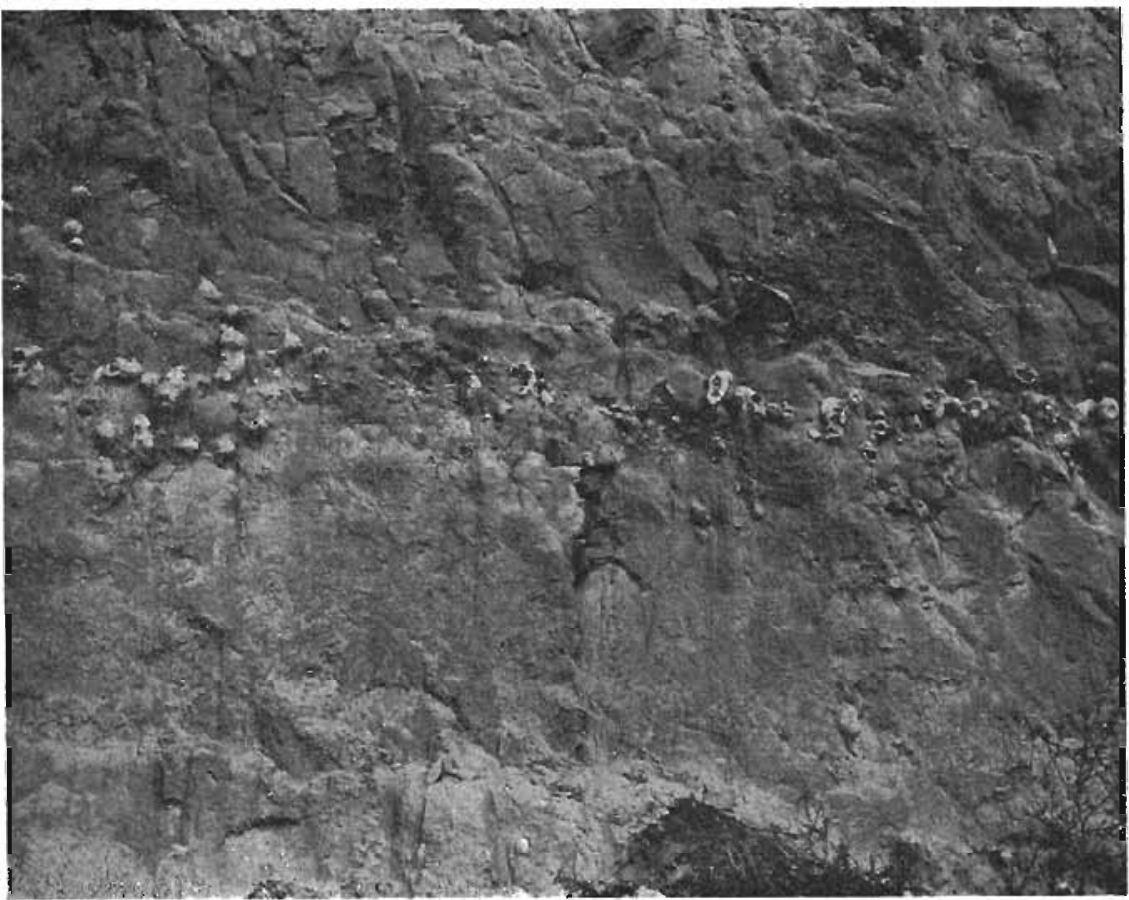

Figure 14. Layer of concretions in the Loveland loess exposed in the valley bluffs near Council Bluffs.

Loveland loess is well exposed in a road cut along the NW1/4 sec. 32, Henry Township, (T. 91 N., R. 43 W.), Plymouth County. The section is:

Peorian intraglacial substage:

Feet Inches Loess, unleached, buff, filled with concretions, sandy in the lower part

Loveland interval:

Loess, leached, carbonaceous; concretions in the upper part, brownish gray. Exposed.

Kansan glacial stage:

Till, unoxidized and unleached, observed below the leached loess 40 rods to the south of the measured section.

A well known exposure of Loveland loess which has remained available for study for many years is in a bluff just back of the 
Third Ward school at Missouri Valley, (T. 78 N., R. 43 W.), in Harrison County. Here the following sequence is seen:

Peorian intraglacial substage:

Feet Inches

Loess, buff in color, unleached, highly fossiliferous... 75

Loveland interval:

Loess, leached, reddish brown, tends to break with

laminations, pebbly in basal part with an occasional

pebble in upper part, contact with drift below and

loess above is sharp and distinct

Kansan glacial stage:

Clay, sandy, yellow, pebbles common, leached

$5 \quad 6$

A hundred yards north of this section, Kansan oxidized and unleached drift is seen to be overlain by 4 feet of brownish, pebbly Loveland with concretions and some fossils, this seeming to grade upward into typical Peorian loess.

A series of good cuts, also in Harrison County, shows a consistent thickness of about 5 feet of Loveland loess. East from the junction of U. S. highway 30 and State highway 39 , the state road cuts through several loess hills between the junction and the county line. On the north side of the road, in the SW1/4 sec. 12, Jefferson Township, is the following section:

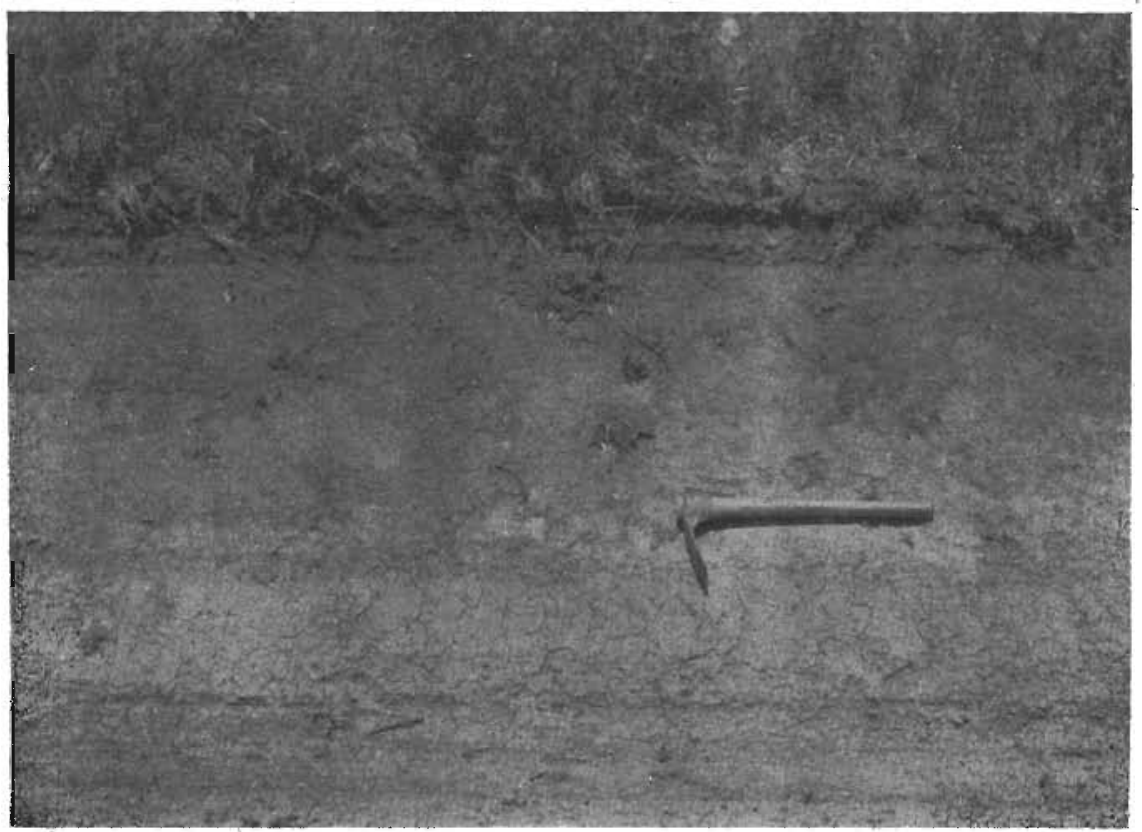

Figure 15. Section showing Loveland loess, Iowan till and Peorian loess. O'Brien County. 


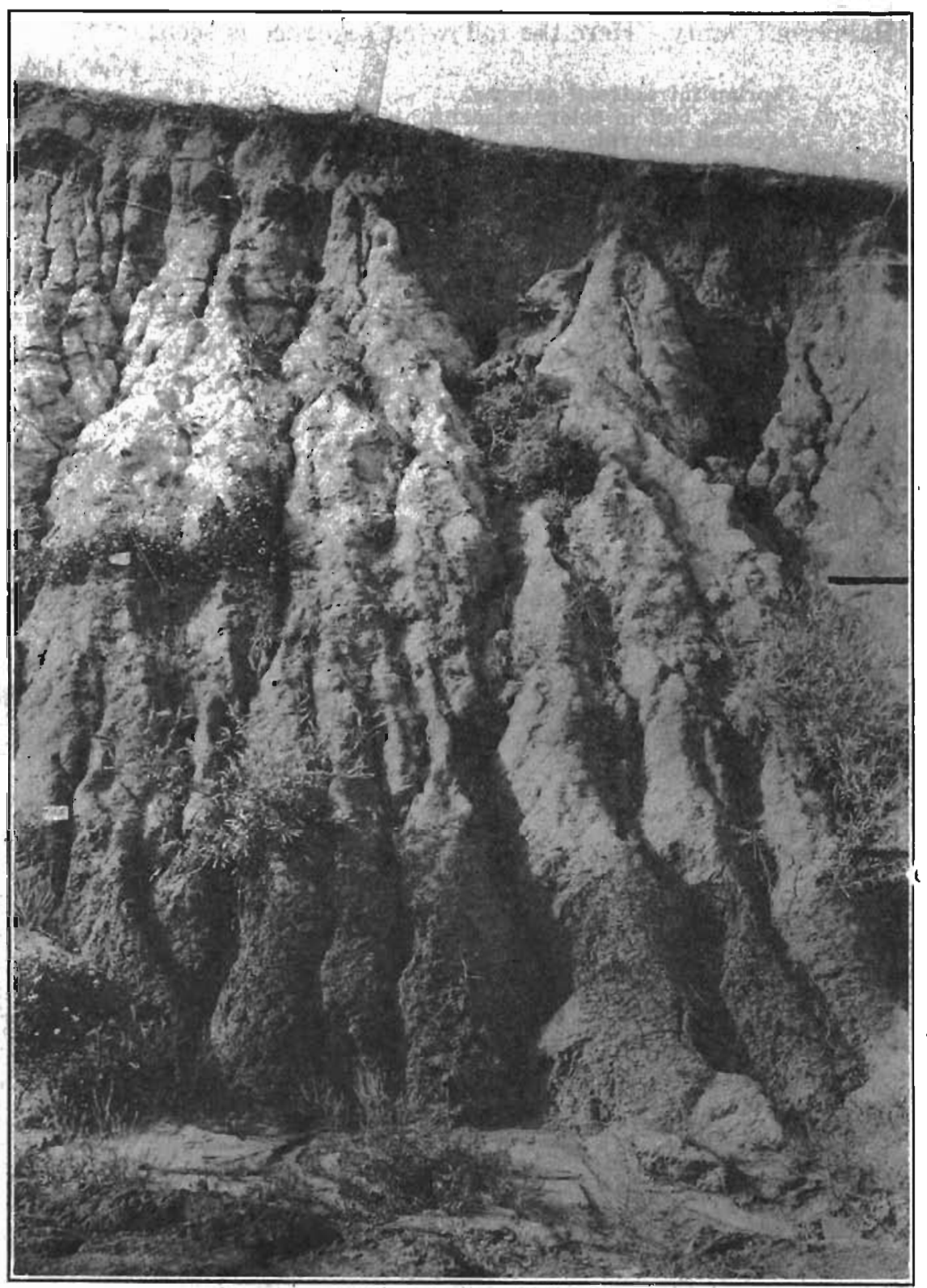

Figure 16. Loveland loess in section in Cass Township, Shelby County. 
Peorian intraglacial substage:

Feet Inches Loess, buff, concretions

Loveland interval:

Loess, distinct reddish tint, more sandy than the

Peorian, has concretions, leached.

Three more similar sections are seen in the next 3 miles to the east, showing an average of 5 feet of leached Loveland loess below Peorian loess. Below the Loveland in each case is oxidized and leached Kansan till.

In northwestern Iowa, the Loveland loess and the usually overlying Peorian loess is separated by Iowan drift. This relationship is shown along the road between secs. 4 and 9, Carroll Township, (T. 96 N., R. 42 W.), O'Brien County (fig. 15).

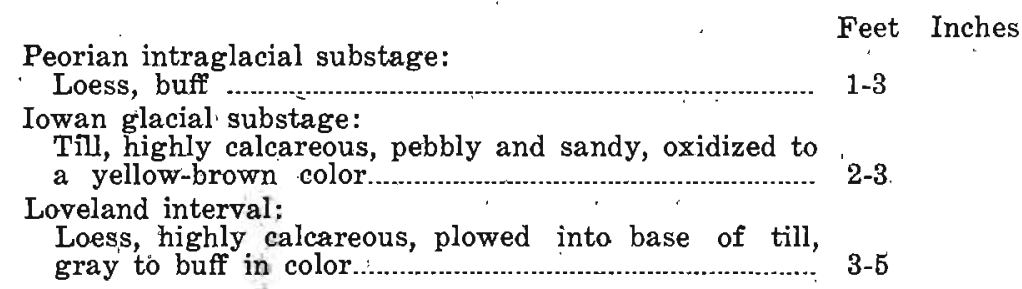

The Loveland loess lies on Kansan gumbotil in a cut between secs. 15 and 22, Cass Township, (T. 79 N., R. 40 W.), Shelby County (fig. 16). A section is as follows:

Peorian intraglacial stage:

Feet Inches

Loess, leached, upper part buff in color, grading down into gray loess with iron stains, iron tubules............ 12

Loveland interval: Loess, leached, brownish gray with numerous brownish-yellow stains, differs distinctly from material above and below.

Kansan glacial stage:

Gumbotil, dark gray to brown, upper part shows considerable secondary calcium carbonate in places, leached. Exposed.

The same relationships were seen in a section a few miles east between secs. 16 and 21, Lincoln Township, (T. 79 N., R. 39 W.), Shelby County. In this place the Peorian loess is 7 feet thick, the Loveland is 3 feet thick, and the Kansan gumbotil is exposed for a thickness of 2 feet.

Several sections in northeastern Iowa show the Iowan till overlying the loess phase of the Loveland formation. A section in Fayette County, unusual in its completeness of Pleistocene formations of the area, figure 17, is found along the north line of sec. 16, 
Windsor Township, (T. 94 N., R. 9 W.). Here the sequence of formations related to the loesses is:

Peorian intraglacial substage:

Feet Inches

Loess, buff, mealy, unleached, some concretions, no fossils found

Iowan glacial substage:

Till, unleached, dark buff on dry surface, yellow brown to brown when damp, cuts readily with hoe, sandy, few concretions.

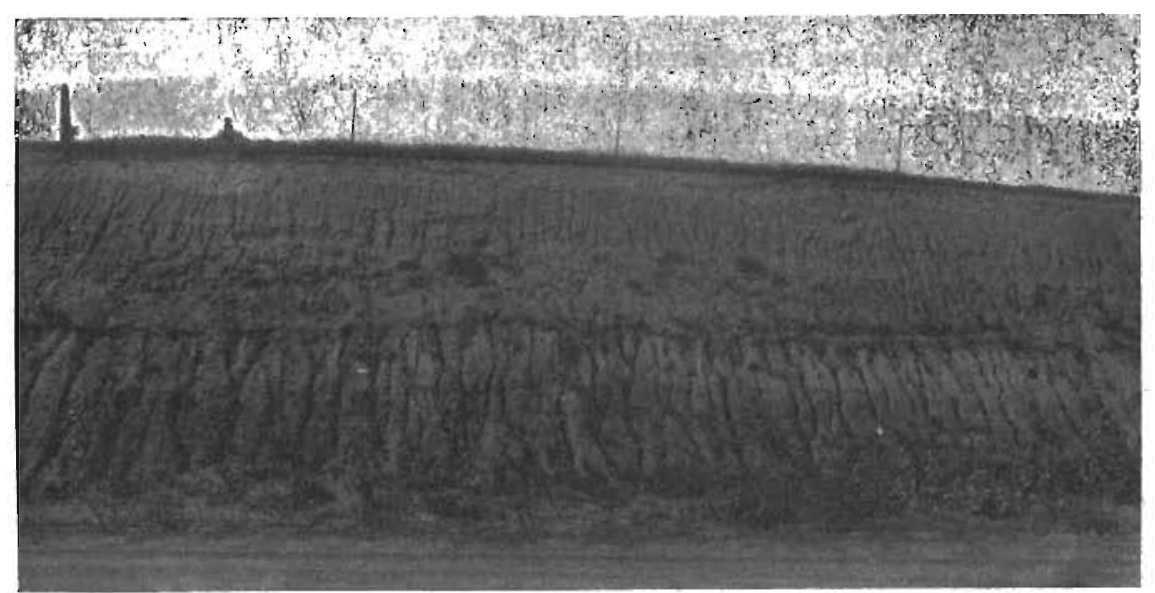

Figure 17. Section in Fayette County, showing Loveland loess below Iowan till.

Sangamon interglacial stage:

Loess, Loveland, leached, gray, with considerable chocolate-colored stain, laminated, putty-like when wet, no pebbles found.

Kansan glacial stage:

Gumbotil, leached, dark gray on a dry surface, no concretions seen, very few pebbles of any kind-those found all siliceous. Upper $11 / 2$ feet contains much carbonaceous matter which shows a distinct soil band through the cut.

Excavations made during the building of the stadium at the University of Iowa, in Iowa City, (T. 79 N., R. 6 W.), Johnson County, gave good exposures of both Loveland and Peorian loesses. The relations are:

Peorian intraglacial substage:

Feet Inches

Loess, buff color, leached to top of slope

Loess, calcareous, buff color, iron tubules, fossil shells

Loess, distinct gray, many iron tubules which show dis-

tinctly on the surface of the slope, many fossil shells 


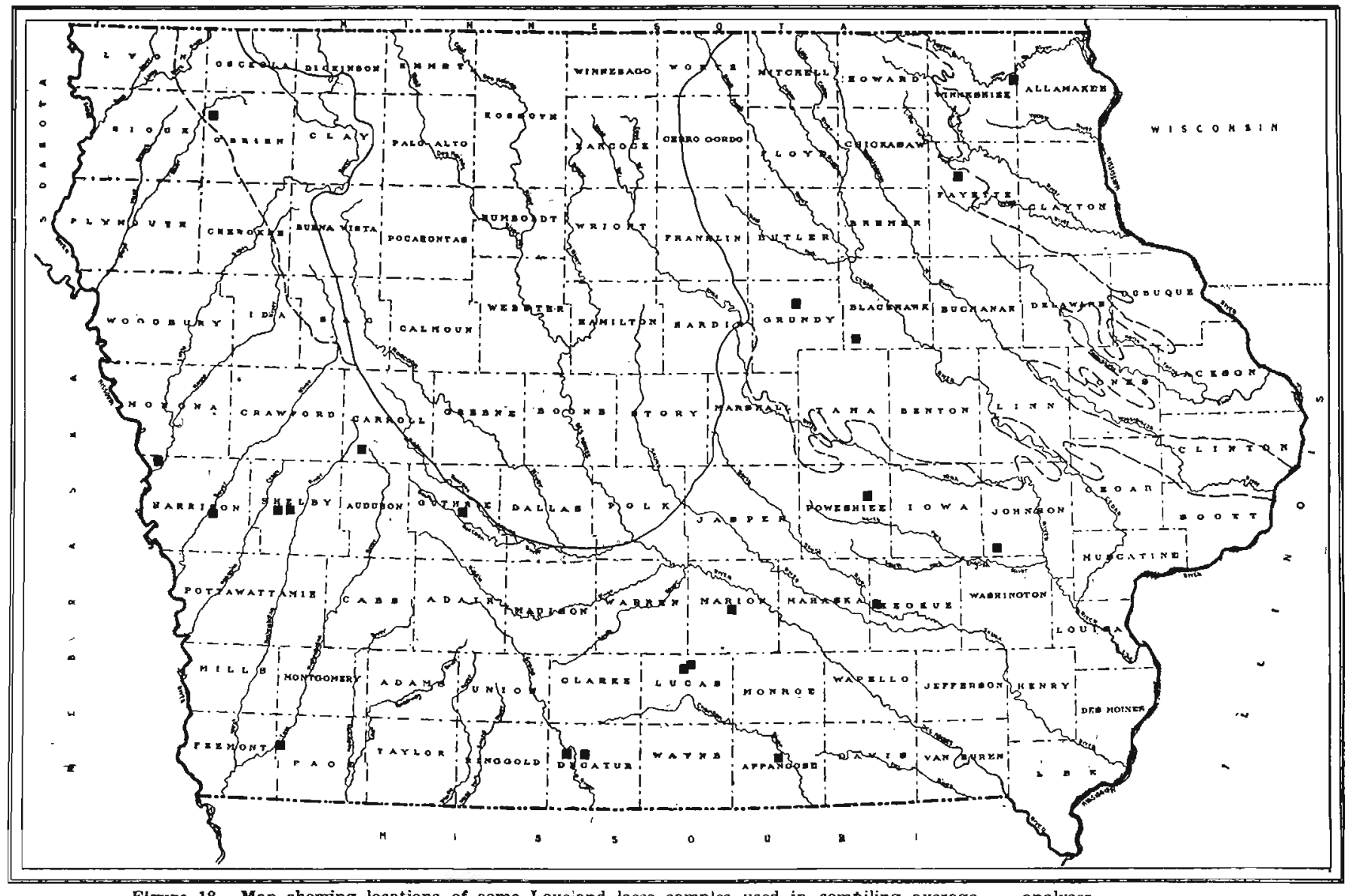

Figure 18. Map showing locations of some Loveiand loess samples used in compiling average 


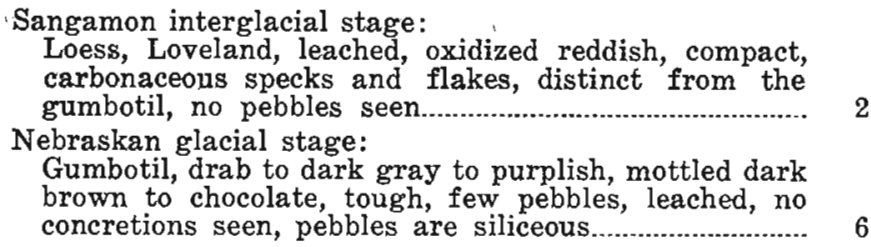

The Loveland loess is well exposed in this excavation; the contact between the gumbotil and the overlying compact Loveland loess forms a zone of seepage which makes these materials easily discernible. The Loveland averages about 2 feet in thickness over the area and in general appearance is much like the Loveland of western Iowa.

Laboratory Studies of the Loveland Loess

\section{Mechanical Analyses}

A total of 35 samples of Loveland loess were collected from widely separated localities over the state, as shown by figure 18 , and the materials were subjected to various laboratory analyses by Paul $\mathrm{T}$. Miller. The following size relationships are shown by the mechanical analyses:

The average of the Loveland samples shows a fairly well-balanced distribution of particles both coarser and finer than the maximum size grade percentage, which falls in the $1 / 16$ millimeter to $1 / 32$ millimeter range. This size grade maximum is the coarse silt dimension, and constitutes about 35 percent of the whole. The finest size grade, that of $1 / 128$ millimeter to $1 / 256$ millimeter dimensions, contains 7 percent. The coarsest size grade of significance here is that of 1 millimeter to 1/2 millimeter range, and contains between 1 and 2 percent of the whole. Loveland loess is, known to contain sand and pebbles ranging in diameter from 1 millimeter up to 4 millimeters, but the percentage of this coarse material is very small. Figure 19 illustrates the percentage of the various size grades.

\section{Mineral Analyses}

Loveland loess rests upon the eroded surface of the Kansan gumbotil over large areas in Iowa. The question arises as to whether the loess was blown into the state from the west and southwest or whether it was derived locally from stream deposits or reworked Kansan drift. The mineral analyses of the Loveland loess correlate closely with the mineral analyses of the Kansan till, which sug- 


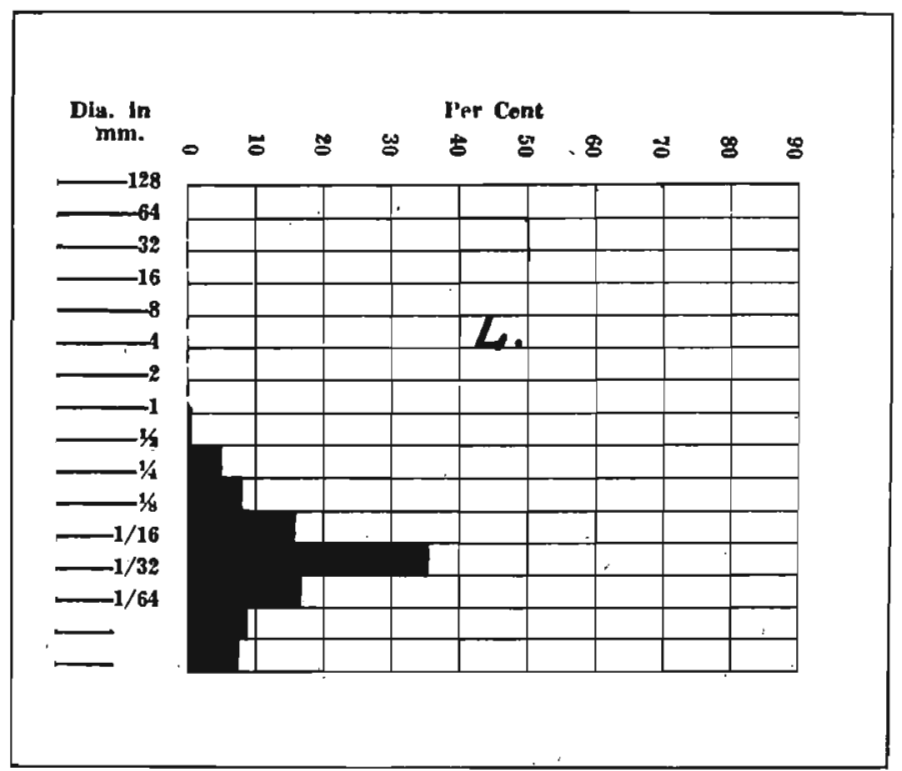

Figure 19. Graph showing mechanical analysis of average of 35 samples of Loveland loess.

gests that the loess in Iowa is of local origin. After the formation of the gumbotil, streams cut through it into the drift and developed wide flood plains. Here fine material could easily have been gathered by the winds and deposited over the surrounding region.

Major constituent minerals of Loveland loess and Kansan till have been determined by Paul Miller as shown in the following tabulation:

Minerals

Quartz

Undifferentiated feldspar

Microcline

Plagioclase (Albite)

Minor constituent minerals are:

Minerals

Pyrite

Magnetite and Ilmenite

Hornblende

Pargasite

Glaucophane

Actinolite

Tremolite

Hypersthene

Enstatite

Augite

Aegerite-Augite

Aegerite

$\begin{array}{cc}\text { Kansan till } & \text { Loveland loess } \\ 87.20 \% & 81.30 \% \\ 9.29 & 9.82 \\ 1.74 & 2.58 \\ 1.94 & 3.32\end{array}$

Kansan till Loveland loess

$\begin{array}{rr}2.55 \% & 16.40 \% \\ 11.12 & 9.03 \\ 38.14 & 32.36 \\ 1.09 & 1.75 \\ .42 & 1.31 \\ .78 & 1.02 \\ 1.09 & \\ 1.81 & .72 \\ 1.33 & .43 \\ 3.45 & 2.40 \\ .54 & \\ .54 & 1.06\end{array}$




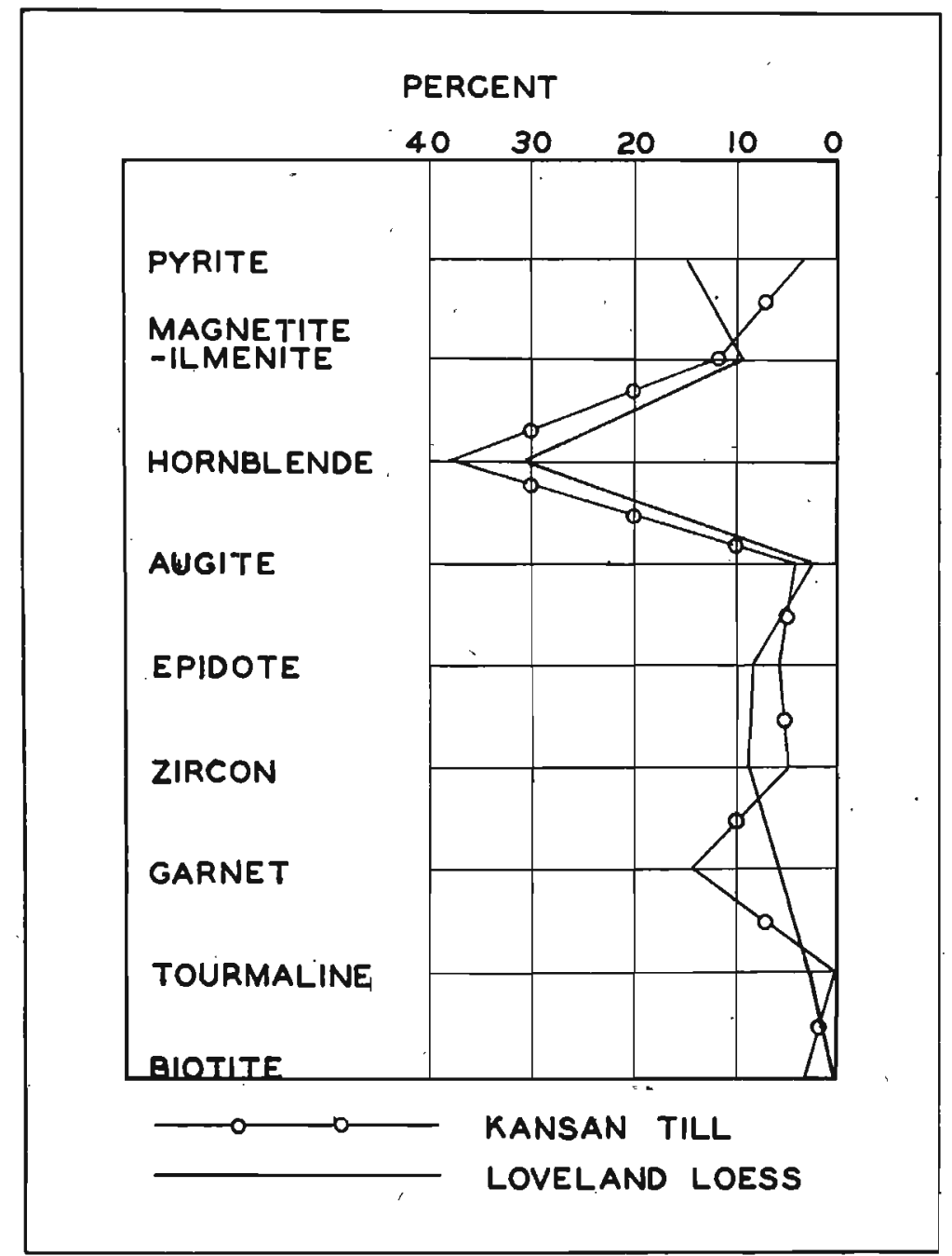

Figure 20. Diagram illustrating similarity of minor mineral percentages in Kansan till and Loveland loess. 


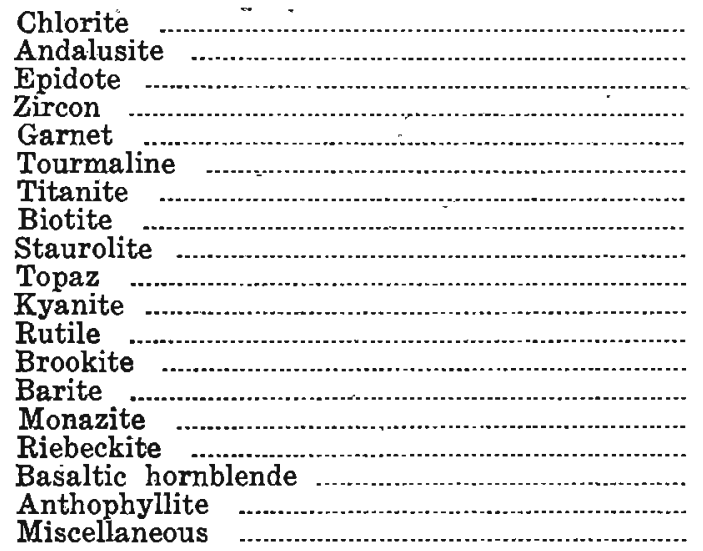

$\begin{array}{rr}1.57 & .42 \\ 7.51 & .80 \\ 5.55 & 8.76 \\ 15.22 & 9.22 \\ .49 & 5.47 \\ .78 & 3.23 \\ 3.77 & 2.23 \\ .18 & .49 \\ .73 & .80 \\ .73 & .27 \\ .01 & .27 \\ .12 & .12 \\ .54 & \\ .95 & .10 \\ & .54 \\ & .27\end{array}$

Figure 20 illustrates the correlation of the most important minor constituent minerals of Kansan till and Loveland loess.

\section{Loveland Sands and Gravels}

Sands and gravels of Loveland age are confined largely to several valleys in the western and southern parts of the state as shown in figure 21 . The valleys in which sands and gravels have been identified as Loveland in age lie wholly within the loess mantled Kansan erosional drift area. The sources of the sands and gravels must be, therefore, the eroded Kansan drift, the Nebraskan drift, the bedrock, or a combination of these sourees.

The occurrence of widespread valley terrace gravels of postKansan, pre-Peorian age, the lack of Kansan gumbotil, and the topographic differences between northwestern Iowa and southern Iowa are thought to be the result of uplift in northwestern Iowa which occurred during the Loveland interval. A brief summary of the evidences supporting the view of uplift in northwestern Iowa will clarify the discussion of the relationships of the Loveland gravels which is to follow.

Carman ${ }^{38}$ studied thoroughly the Pleistocene geology of northwestern Iowa. In relation to the postulated uplift of that region, Carman states:

"In the Kansan drift region of southern Iowa the principal divides of a region commonly rise to a uniform altitude and have some level surface at their summits. These level areas are interpreted as remnants of the original Kansan drift plain, which is thought to have been relatively level without marked constructional features.

Carman, J. E., Further studies of the Pleistocene geology of northwestern Iowa: Iowa Geol. Survey, vol. 35, pp. 108-111, 1931. 


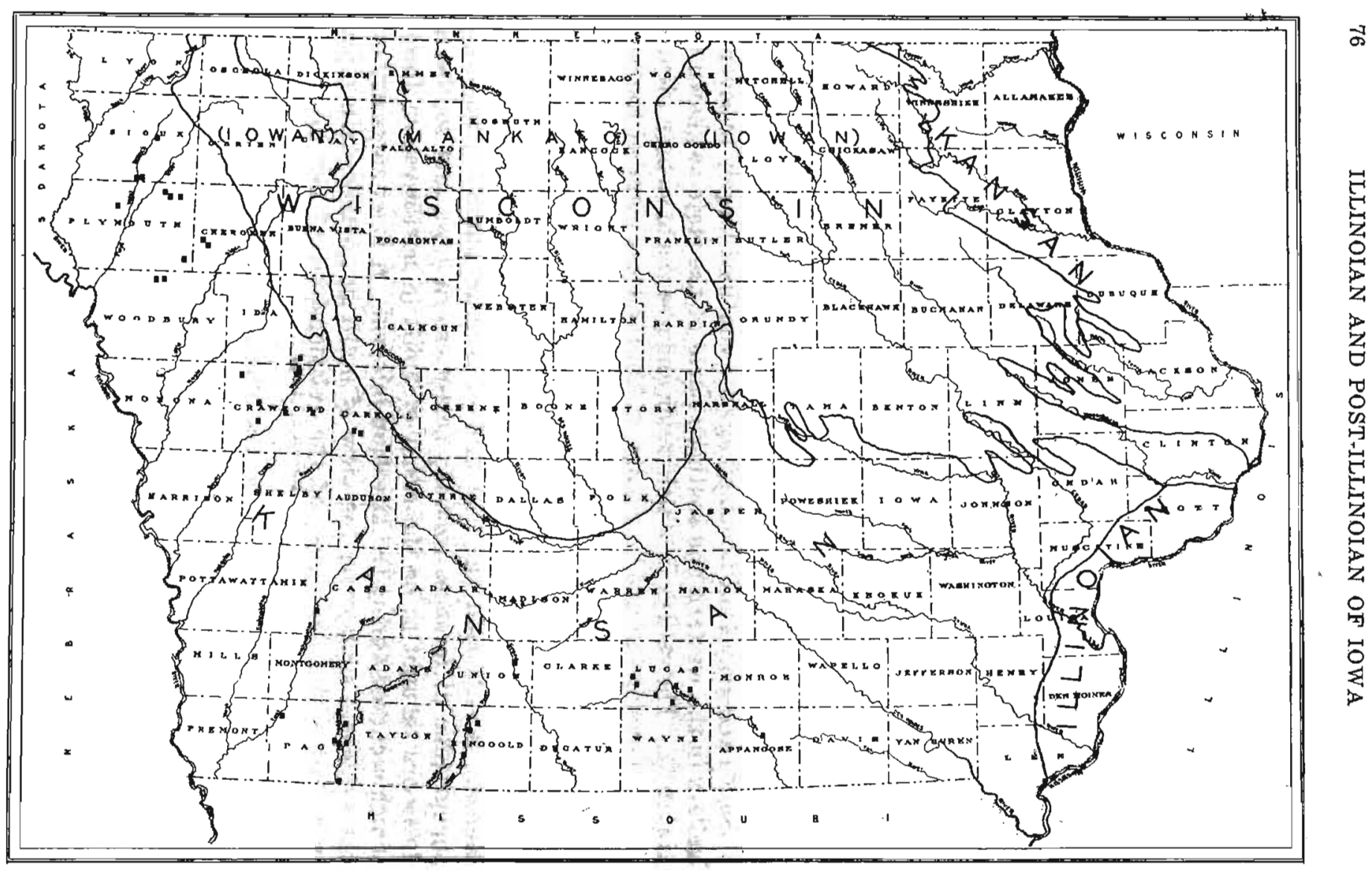

Figure 21. Map showing locations of Loveland sand and gravel expasures in Iowa. 
"These level uplands of southern Iowa are covered with about ten feet of gray to dark colored noncalcareous sticky clay which Doctor Kay has named gumbotil and interpreted to: be the result, chiefly, of the chemical weathering of Kansan drift on the level Kansan drift plain. After the development of the gumbotil zone an uplift is believed to have occurred, and erosion has carved out a mature topography and reduced most of the surface below the level of the former gumbotil plain. The above interpretation is based on the evidence of the remnants of this plain.

"Remnants of the gumbotil zone are numerous in southern Iowa and continue northward to Carroll and Crawford counties, just south of our region ${ }^{39}$ (northwestern Iowa). The most northerly known exposure of the Kansan gumbotil is in a railway cut two miles east of Kiron, a few miles south of the southwest corner of Sac county.

"Neither the level uplands nor the gumbotil have been found within our region, although exposures of unleached till have been seen on most of the high areas. However, it is believed northwestern Iowa has passed through essentially the same history as has been outlined for southern Iowa by Kay. That is, that the Kansan ice sheet left a relatively even drift plain; that the gumbotil and the leached zone below were developed over the entire region; that the gumbotil plain was uplifted; and that it has since been eroded. This erosion; however, has been greater in northwestern Iowa than in southern Iowa, so that, although remnants of the' plain and the gumbotil remain in southern Iowa, in northwestern Iowa all the surface has been reduced below the level of the gumbotil plain and every remnant of the plain, the 'gumbotil and the leached zone has been destroyed.

"Concerning this matter of erosion of the gumbotil plain in Carroll county just to the south of our area Kay wrote as follows:40

"The history of northern Carroll county and" farther to the north seems to have differed from the history of the Templeton region (southern Carroll county) in having undergone still greater erosion. Northward from Templeton there are fewer and fewer remnants of the weathered zones until none are found. Moreover, in the region of Templeton there appears to have been more erosion than farther to the south. In south-central Iowa the uneroded remnants of upland with gumbotil and leached drift are a somewhat distinctive feature of the topography.'

"The above explanation includes several points that have not been conclu. sively proved, but the interpretation explains the conditions fairly well. It has not been proved that the gumbotil plain extended over northwestern Iowa. However, the writer has seen a good deal of the evidence in southern Iowa and in Carroll and Crawford counties just south of our region, upon which $\mathrm{Kay}$ bases the gumbotil interpretation, and considers it so strong that he eannot fail to use this interpretation for the southern part of the region here under discussion. It is believed that the development of the gumbatil to a depth of ten to fifteen feet over southern Iowa required a very great length of time. Such thicknesses are found northward to Carroll county, where a section recorded by $\mathrm{K}$ ay from a railway cut three miles west of Templeton shows fifteen feet of Kansan gumbotil. A deposit of this origin and representing such a great. lapse of time could not terminate abruptly and, therefore, it seems very probable that the gumbotil was developed farther northward over northwestern Iowa during this same long interval of time.

"The way in which the remnants of the' gumbotil on the highest divides become fewer and smaller as they are traced northward in west central lowa, and especially in Carroll county, indicatess strongly that these remnants have been entirely destroyed farther north; that is, that northwestern lowa has been entirely reduced below the level of the gumbotil plain. The unleached Kansan drift at the surface in northwestern Iowa is similar in all respects to the unleached Kansan drift which exists beneath the leached drift and gumbotil farther south. The altitude of the remnants of the gumbotil along the divide between the Mississippi and Missouri rivèrs increases gradually north-

Kay, G. F., Pleistocene deposits between Manilla in Crawford County and Coon Rapids in Carroll County: Iowa Geol. Survey, vol. 26, pp. 213-281, 1917.

${ }^{40 K a y, ~ G . ~ F ., ~ o p . ~ c i t ., ~ p . ~} 218$. 
ward from about 1,200 feet at Tingley, near the south line of the state, to nearly 1,500 feet west of Templeton in Carroll county. If these altitudes are used to project the plain northward, it is found that it would pass above all the high points of northwestern Iowa.

"An uplift is postulated in order to allow the dissection of the gumbotil plain. In southern Iowa, where remnants of the gumbotil plain exist, the postulated uplift rests on firmer basis than in northwestern Iowa, where the uplift is merely inferred. The question as to why northwestern Iowa was eroded more deeply than southern Iowa, in spite of the fact that it is farther up the Missouri valley, has not been satisfactorily answered. Possibly the uplift in northwestern Iowa was greater than in southern Iowa; possibly it occurred earlier. There exist in northwestern Iowa considerable areas of slight relief which by this hypothesis must be interpreted as having been reduced below the original plain; and yet they are not at flood-plain level. The origin of these areas is not understood."

All persons who have studied the Kansan drift of northwestern Iowa have been puzzled to find how free from leaching the till is as compared with the leaching of the Kansan till of southern Iowa. In attempting to explain these differences Carman stated:

"A notable character of the Kansan till of northwestern Iowa is the small amount of alteration and weathering which it shows. Oxidation to a yellow color commonly extends to a depth of twenty to thirty feet, and locally the till is iron-stained along the joints, but the degree of this oxidation is only moderate. Excessive oxidation of the type represented by the iron-stained horizon (ferretto) present at the top of the Kansan till at many places farther south, is lacking in northwestern Iowa. Further, the Kansan till of northwestern Iowa is commonly calcareous to the surface. In only a few places, in the south and southwest part of the region, was any leached till found. Even where the overlying loess is leached for its entire thickness, the till beneath is unleached.

"In southern Iowa leached till is much more commonly present and in many places has a depth of several feet. It occurs in a zone which directly underlies the gumbotil of the remnants of the upland, where it may be seven to ten feet thick. In such position it grades upward into the gumbotil and represents a less altered phase of the till.

"If a gumbotil zone was formed over the Kansan drift plain of northwestern Iowa, there was formed also beneath it a zone of leached till, but the erosion which removed every vestige of the gumbotil also removed the leached zone of Kansan till beneath, exposing unleached till everywhere at the surface. This complete erosion of northwestern Iowa below the original plain explains the absence of leached till."

The finding of widespread sands and gravels of Loveland age in western and southern Iowa is in accord with this hypothesis of uplift and erosion in northwestern Iowa. It is probable that all valleys in western and southern Iowa were aggraded to some degree with Loveland sands and gravels. However, Iowan and Mankato glaciation has resulted in valley terracing of the valleys which head in the areas of those drifts, and the differentiation of valley sands and gravels as Loveland in age is possible only in areas which have been unaffected by Wisconsin drainage. Gravels in northwestern Iowa valleys which may have carried Iowan, or Iowan and Mankato glacial drainaige, have been designated "undifferentiated terrace gravels" 
by Kay and Miller ${ }^{41}$ and the locations of such gravel deposits are shown on the map in figure 22. Admittedly, these gravels may be in part Loveland gravels.

The most complete field and laboratory study of Loveland sands and gravels has been made by Kay and Miller ${ }^{42}$ and the following discussion is based largely on this report.

The Loveland sands and gravels of northwestern Iowa have been altered very little by weathering. They are fresh in appearance. Oxidation has changed the color of the deposits to buff, but nowhere has the deep red color or iron cementation of highly oxidized gravels been observed. The materials are unleached except where the thinness of the loess cover has permitted post-loessial leaching to penetrate into the upper few inches of gravel. There has been little disintegration of the igneous pebbles within the gravels.

The sands and gravels are usually stratified in horizontal beds between 6 and 12 inches thick. The deposits frequently show considerable variation in sorting and in size range. Silts and sands may be interstratified with gravel and cobbles and occasional boulders up to 60 centimeters in diameter may be found in the finer material. The mechanical analyses of average samples from each of several Loveland deposits have been grouped for comparison and are shown in figure 23 . The corresponding pebble analyses for the same deposits are shown in figure 24.

There are many exposures of Loveland terrace deposits along the tributary streams of Missouri River, which have their source areas in the eroded Kansan drift region of northwestern Iowa and which have not carried Iowan or Mankato glacial drainage. Deposits of this type occur along Otter Creek, a tributary to Boyer River, in the southwest part of Sac County. A series of gravel pits have been developed along the east side of a valley terrace near the center of the W $1 / 2$ sec. 26 , Wheeler Township, (T. 86 N., R. 38 W.), about 5 miles south of the southeast corner of Odebolt. In one pit, a 42foot section is exposed. The upper 20 feet is typical Peorian loess, leached to a depth of 9 feet, and extending to the sharp gravel contact at its base without variation in texture or color. Below is 22 feet of gravel without a visible contact at the base.

The sand and gravel has been oxidized to a light-buff color, and except for a $2 \frac{1}{2}$-foot sand layer at the top, is calcareous throughout. This sand is believed to represent an original lack of calcium carbo-

"1 Kay, G. F., and Miller, P. T., The Pleistocene gravels of Iowa: Iowa Geol. Survey, vol. 37, p. 197, 1941. 


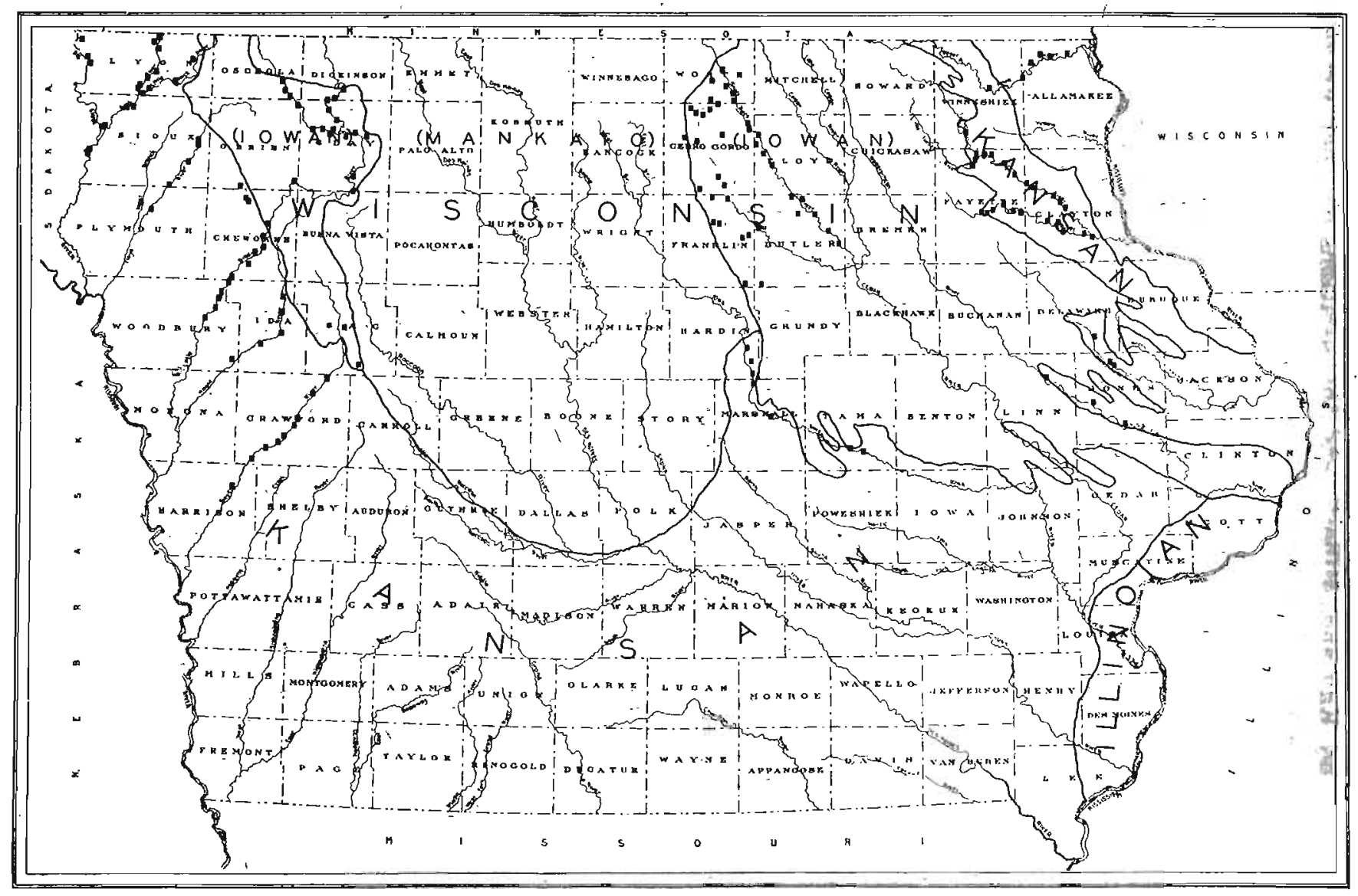


nate rather than subsequent leaching, as some interstratification of this- sand with calcareous gravel lenses has been observed. There has been little disintegration of the igneous rock content of the gravel. Concretions are absent. In size range, the gravel is mostly below 6 centimeters in diameter, although a number of boulders ranging to a diameter of 35 centimeters were found in the bottom of the pit. Seventy percent of the gravel is between 4 millimeters and $1 / 4$ millimeter in diameter, as shown in graph no. 1 of figure 23. The gravel is stratified in beds generally about 3 inches thick which dip southeast at an angle of less than 5 degrees. The lithology of the gravel is shown by graph no. 1 in figure 24 .

A section along. Deep Creek in the south-central part of sec. 31, Meadow Township, (T. 93 N., R. 43 W.), Plymouth County, includes 45 feet or more of Loveland gravels. The top of the gravel is exposed in a terrace 20 feet above the level of Deep Creek. The gravel is overlain by 3 to 4 feet of loess, dark from humus in the upper 18 inches, but light buff below. All of the loess is leached.

The gravel is exposed to a depth of 10 feet, and borings have indicated a total depth of $\mathbf{4 5}$ feet or more. The gravel in the upper, exposed portion shows no leaching and has been changed to a lightbuff color by oxidation. Disintegration of igneous pebbles is slight. The deposit is well stratified, with strata usually less than 10 inches thick, which dip to the southwest at an angle of about 3 degrees. In size range, a few boulders and cobbles as large as 25 centimeters in diameter have been found,-but about 85 percent of the deposit is between 16 and $1 / 4$ millimeters in diameter. The mechanical and lithological analyses of an average of the gravel from this exposure is given in graph no. 4 in figures 23 and 24.

On Brushy Fork, a tributary of South Raccoon River, Loveland gravels are exposed in the central part of sec. 20 , Newton Township, (T. 82 N., R. 34 W.), Carroll County, in the southwest corner of Dedham.

Here leaching has removed the carbonates from 4 feet of loess overburdened and from the upper 6 inches of gravel. The gravel is a slightly darker buff color than the sections described earlier. Pebble disintegration has been slight. The gravel is well stratified, with cross bedding, common within the major beds. Texturally, about 50 percent of the gravel is between 1 and $1 / 4$ millimeters in diameter. With the exception of a few large boulders which have a maximum diameter of 30 centimeters, none of the gravel measured 


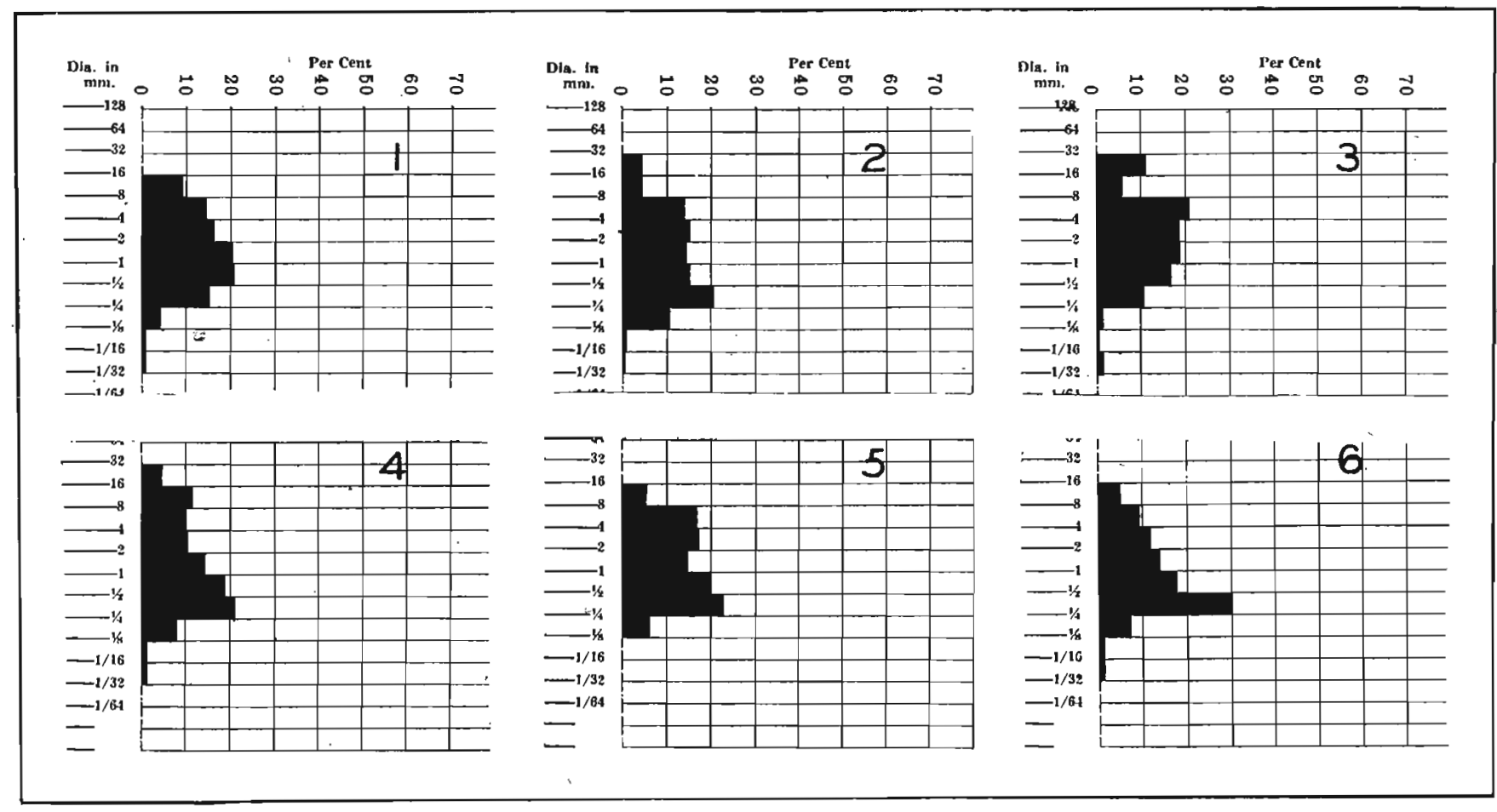




\section{No 1}

No 3

No 5

PER CENT-- - 0 ㅇํㅇ \&

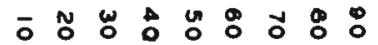

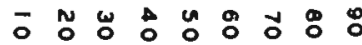
GRANITE- - - - - - - - GABBRO - : DOLERITE \& BASALF . - -

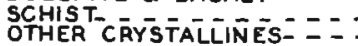
QUARTZITEQUARTZ-NE - - - - - - - - CIMESTONE \& DOLOMITE- CHERT- - - - - . . - -

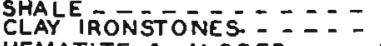
HEMATITE \& JASPER.-. UNIDENTIFIED
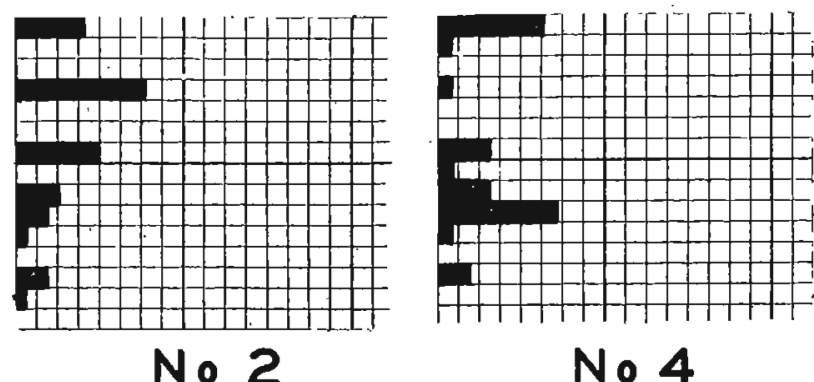

$$
\text { - No } 2
$$

No 4

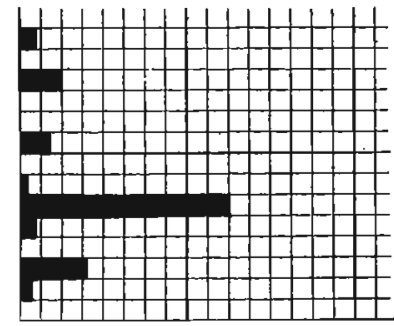

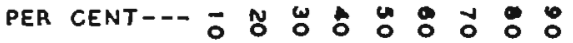

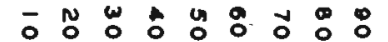

No 6

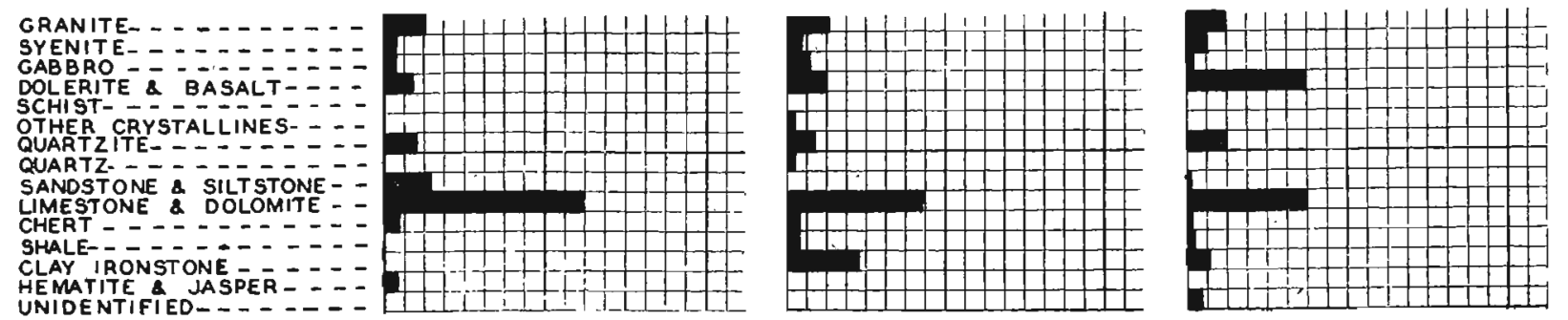
The numbers of these analyses correspond to those of figure 23 . 
more than 5 centimeters in diameter. The mechanical analysis of an average sample is shown by graph no. 6 of figure 23 , while the lithology of the gravel is represented by graph no. 6 of figure 24 .

The Loveland sands and gravels of southern Iowa differ in several respects from the gravels of northwestern Iowa which have just been described. Younger loess and alluvium obscure the Loveland deposits in most places as the Loveland silts, sands and gravels are situated low in the valley walls and in many places the streams have not cut deeply enough to expose them. That the presence of these materials has long been recognized, is apparent from the work of Calvin. ${ }^{43}$ However, he did not give them the same interpretation which has subsequently been determined for them, as the formational nature of materials in the present Loveland formation had not been worked out at that early date.

About 3 miles east of Clarinda, Loveland silt, sand and gravel is exposed in a dredged ditch along the East Nodaway River, in the SW $1 / 4$ sec. 34, Nebraska Township, (T. 69 N., R. 36 W.), Page County. The section is :

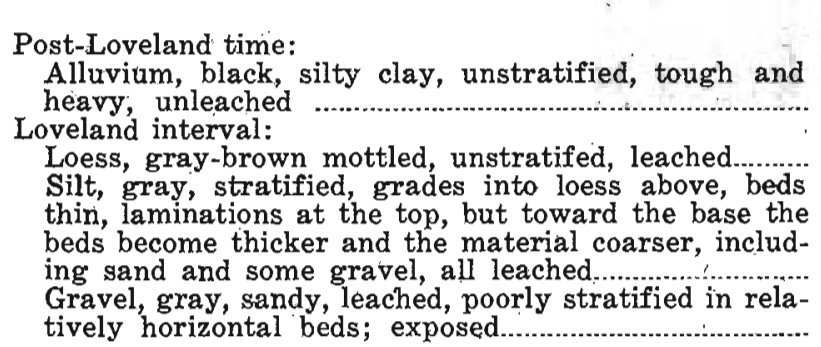

Gravel, gray, sandy, leached, poorly stratified in rela-

Several exposures of Loveland deposits in Lucas County have been observed. One of these is along a branch of White Breast Creek, near the center of sec. 21 , Benton Township, (T. $71 \mathrm{~N}$. R. 21 W.). This entire section is leached of its carbonates. The section is:

Loveland interval:

Feet Inches

Soil filled with roots

Sand, gray; and gravel, oxidized, brownish and red-

dish, strongly cemented.

Sandy clay band

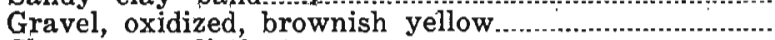

Clay seam, distinct.

Sand, white

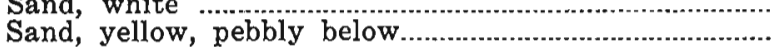

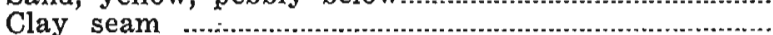

Sand, white with yellow streaks, oxidized at base....

Kansan glacial stage:

Till, yellowish gray.

2

3

$1 \quad 6$

2

1

2

1

8

${ }^{43}$ Calvin, Samuel, Geology of Page Coanty: Iowa Geol. Survey, vol. 11, pp. 444-447, 1901. 
If there is any Peorian loess here, it is very thin:

A comparison of the Loveland sands and gravels in northwestern Iowa with those in southern Iowa seems to indicate a difference not only in weathering but in type of material. It is probable that the terrace gravels described in northwestern Iowa were deposited fairly late in the Loveland interval, and that they are made up largely of materials that had undergone but little weathering. In southern Iowa, the more advanced oxidation and leaching of most exposures seems to indicate that those materials were deposited earlier in the Loveland interval than were the gravels of northwestern Iowa. Furthermore, the Loveland streams in southern' Iowa probably contained a much higher percentage of weathered material than did the contemporaneous streams in northwestern Iowa, which 'were supplied for the most part by the relatively rapid erosion of unleached Kansan drift.

As yet, it has not been possible to establish accurately the chronology of Loveland deposits within the long Loveland interval. While it is true that some deposits, by virtue of their stage of weathering, can be said to be younger or older than other similar deposits, Loveland sands and gravels cannot be given a Sangamon, Illinoian, or late Kansan age with any certainty. Additional investigation of the Loveland formation as a unit may reveal that less inclusive age determinations are possible for these Loveland sands and grave's.

\section{Volcanic Ash in the Loveland Formation}

Volcanic ash or pumicite occurs in the Loveland formation in western Iowa, eastern Nebraska, and eastern South Dakota. In Iowa, the volcanic material has not been found in thicknesses exceeding 3 feet, but in Nebraska the ash is, in places, 3 to 8 feet thick, and southwest of Eustice, Frontier County, it is 50 feet thick in places. ${ }^{44}$

The ash is in the lower part of a loess phase of the Loveland formation, or may be associated with Loveland silts and clays showing deposition in water, but changing gradually into the typical eolian loess phase of the overlying Loveland. Frequently, sections of the Loveland which include the volcanic ash indicate that the pumicite was deposited in shallow ponds, lakes or bayous after the sands and gravels of the Loveland age had been deposited. In Iowa, this history is indicated by numerous exposures along Sioux River north of the town of Little Sioux, Little Sioux Township, Harrison County.

4Lugn, A. L., The Pleistocene geology of Nebraska: Nebraska Geol. Survey, Bull. 10, pp. 132-184, 1935 . 


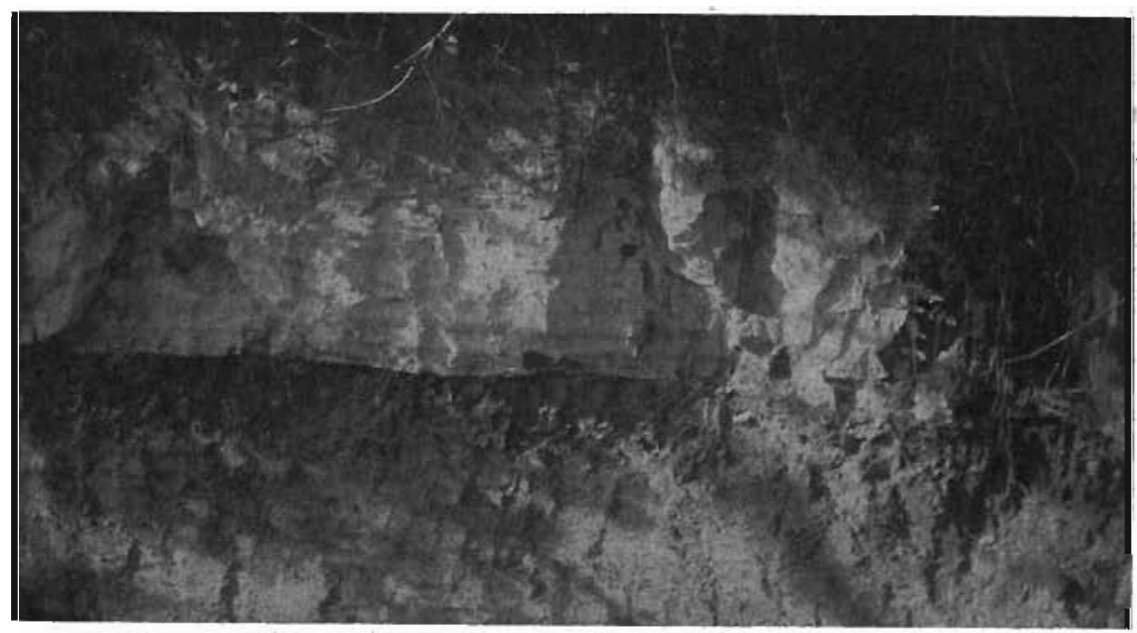

Figure 25a. Volcanic ash in the-Loveland formation. Harrison County.

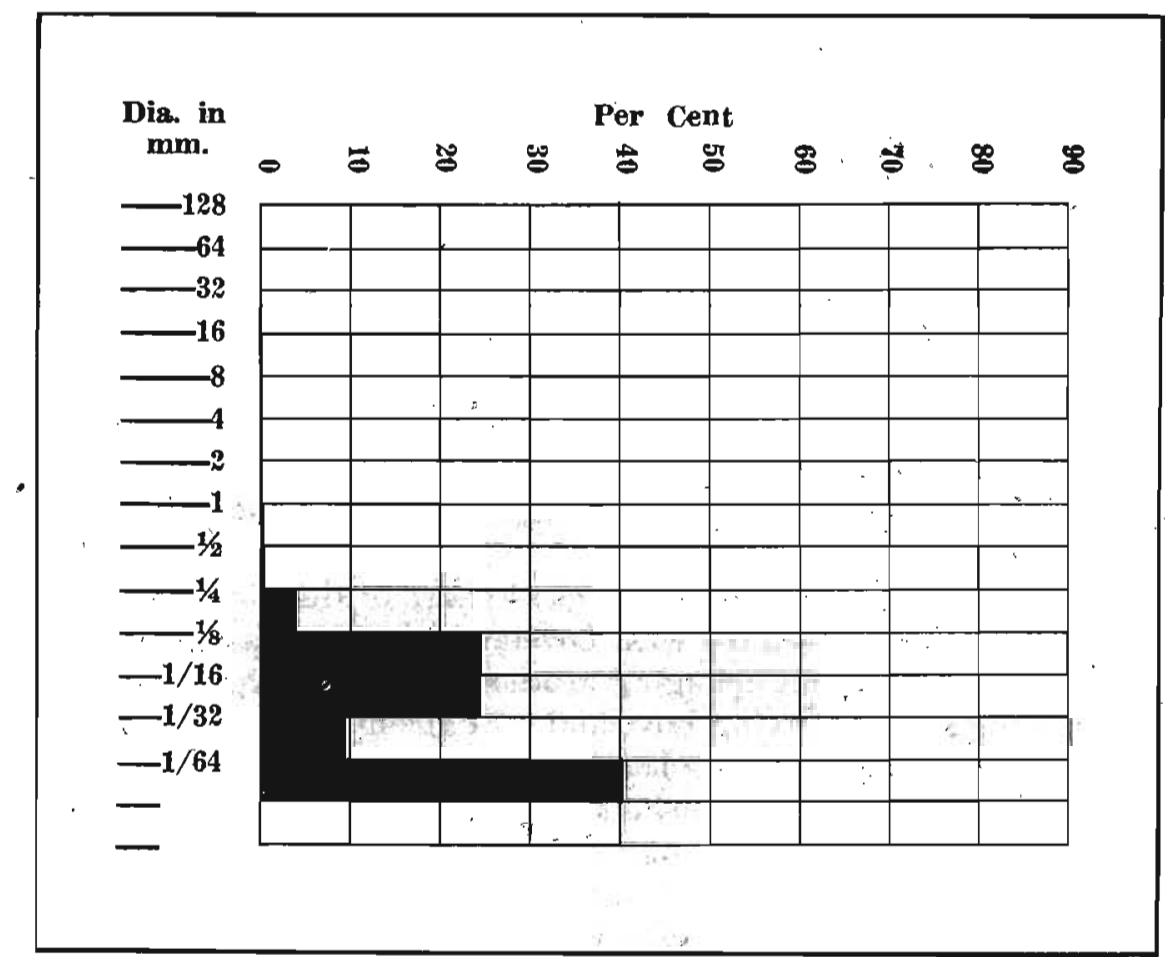

Figure 25b. Graph showing mechanical analysis of Loveland volcanic ash from Harrison County. (After A. C. Tester.) 
Here Sioux River, after entering the valley of Missouri River just north of the Monona-Harrison County line, flows close against the east valley wall north of Little Sioux, and has cut a sharp bluff which rises from the flood plains of Sioux and Missouri Rivers. Gravel pits in the base of this bluff have exposed several good sections of the Loveland formation.

A section of a loess phase which includes the ash is at the so-called County-line exposure, along the north line of sec. 5, Little Sioux Township, (T. 81 N., R. 45 W.), Harrison County. The section follows:

Loveland interval:

Feet Inches

Loess-like clay, brown to yellow in color, concretions, no fossils seen, occasional small pebble. Not sharply separated from the ash below.

Volcanic ash, exposed along the slope for 25 feet, thinning at the ends...................................................... upper part which breaks like joint clay, no fossils seen, concretions, occasional small pebbles, some effervescence with acid.

Sand, base unexposed.

The pumicite layer of this section is shown in figure 25a. About 100 yards south of this exposure the ash overlies gravels. The ash here is somewhat higher than in the section just described.

Only a few yards removed from these two locations, a cut shows oxidized and unleached sands and gravels stained in streaks and lenses with manganese dioxide grading upward into sandy gray silt. The silt is fossiliferous in the upper part. Above the silt occurs a 2 -foot bed of volcanic ash, light in weight in the lower half, but grading upward into a silty, laminated clay. The ash is distinct in its whiteness and light weight. There is no apparent depositional break in sedimentation either above or below the ash.

Several exposures of the ash in this general region clearly show interbedding of the ash and a silty basal phase of the Loveland loess. The relation of the ash to the overlying loess is distinct.

Mechanical and mineralogical analyses have been made of the Loveland volcanic ash by Tester..$^{45}$ Ash from the County-line exposure referred to above consists of the percentages of size grades, shown in figure $25 \mathrm{~b}$ when mechanically analyzed. The $1 / 2-1 / 4 \mathrm{milli}-$ meter size grade consists almost entirely of very angular glass fragments, a small number of rounded detrital quartz grains and about 10 percent of kaolinitic aggregates. The glass and the aggregates are

45Tester, A. C., Personal communication. 
spotted with iron oxide stains. The $1 / 4-1 / 8$ millimeter size grade consists of fragmental glass, about 3 percent of kaolinitic aggregates, and a few rounded to subrounded detrital quartz grains. The glass and the aggregates are spotted with stains of iron oxide. The 1/8$1 / 16$ millimeter' size grade consists of glass in fragments and stringers, practically no aggregates, some detrital quartz grains that show some rounding. Iron stains are also present. The 1/16-1/32 millimeter size grade consists of fragmental glass, a very small number of detrital quartz grains and aggregates, all of which are iron stained. The 1/32-1/64 millimeter size grade has the appearance of the preceding grades with a decrease in the number of aggregates and detrital quartz.

The particles of ash can be classified into four main groups. These types are as follows:

1. Fragments of glass that once inclosed the bubble walls.

2. Y-shaped fragments formed where a number of bubbles were close together.

3. Flat, triangular-shaped plates of glass broken from the walls of large vesicular cavities.

4. Elongate fragments having a fibrous structure.

The mineral content of the ash other than the volcanic glass consists of iron oxide, pyrite, biotite, garnet, quartz and aggregates of weathered aluminum silicate. 


\title{
CHAP̈TER III \\ 'THE ELDORAN EPOCH (SERIES) \\ THE WISCONSIN GLACIAL AGE (STAGE)
}

\author{
The Iowan Glacial Subàge (Substage) \\ The Peorian Intraglacial Subage (Substage) \\ The Mankato Glacial Subage (Substage)
}

THE ClAssification of THE WISCONSIN AGE (STAGE)

The name East Wisconsin was first used by Chamberlin ${ }^{46}$ in 1894 for the most recent of the glacial ages of the Pleistocene period. The following year at the suggestion of Upham the name was shortened to Wisconsin. ${ }^{47}$ Soon two substages, early Wisconsin and late Wisconsin, were recognized. More recently Leverett ${ }^{48}$ described three substages, early, middle and late Wisconsin. The early Wisconsin drift was interpreted to have come from the Labradorean center, the Middle Wisconsin from the Patrician center, and the Late Wisconsin from the Keewatin center. Then in 1931, as a result of detailed field studies in Illinois, Leighton ${ }^{49}$ proposed a modification of the use of the name Wisconsin in Pleistocene classification. The change involved the elimination of the Peorian as an interglacial stage and the inclusion of the Iowan stage as the oldest substage of the Wisconsin. The evidence in Illinois had convinced Leighton and his associates that there was continuous deposition of loess, previously, interpreted to belong to the Peorian interglacial age, from Iowan time until after early Wisconsin time; and furthermore, that the interval heretofore called Peorian was so short as to necessitate its elimination as an interglacial age from the classification of the Pleistocene. Moreover, Leighton proposed that since the Iowan glacial age cannot longer be recognized in Pleistocene classification as being independent in age from Wisconsin age, the usage of the name Wisconsin of our present classification be modified to include the Iowan as the earliest of its substages. He proposed also that the Wisconsin substages be named, from oldest to youngest,' Manitoban (Iowan), Quebecan (Early and Middle Wisconsin), and Hudsonian (Late Wisconsin). Later he realized that the terms herein used were not appropriate, partly because they re-

\footnotetext{
46hamberlin, T. C., in James Geikie, The great ice age, pp. 758-764, 1894.

"Chamberlin, T. C., The classification of American glacial deposits: Jour. Geology, vol. 3, pp: 270-277, 1895 .

is Leverett, Frank, Moraines and shorelines of the Lake Superior region: U. S. Geol. Survey Prof. Paper 154-A, 1929.

LLeighton, M. M. The Peorian loess and the classification of the glacial drift sheets of the Mississippi Valley: Jour. Geology, vol. 38, pp. 45-63, 1931.
} 
ferred to fields of ice accumulation rather than areas where the drift deposits might be studied, and partly because they were preempted. Leighton ${ }^{50}$ therefore proposed other names to replace the names, Manitoban, Quebecan, and Hudsonian, for the substages of the Wisconsin. They are, from oldest to youngest, the Iowan, the Tazewell (Early Wisconsin), the Cary (Middle Wisconsin), and the Mankato (Late Wisconsin).

After Kay had had an opportunity to study Leighton's field evidence in Illinois, he agreed with him that the relationships of the Peorian loess to the Iowan and the Early Wisconsin justified the inclusion of the Iowan in the Wisconsin stage as redefined in the preceding paragraph. Kay and Leighton, ${ }^{51}$ being in agreement with regard to the relationships of the Iowan to the Wisconsin, published a paper together entitled "The Eldoran Epoch of the Pleistocene Period." In this paper, the previous classification of Kay's Eldoran epoch was revised for the Mississippi Valley. as follows:

\begin{tabular}{l|c|c}
\hline \multicolumn{1}{c|}{ Epoch (series) } & Age (stage) & \multicolumn{1}{c}{ Substage } \\
\hline Eldoran & Recent & $\begin{array}{l}\text { Mankato (Late } \\
\text { Wisconsin) } \\
\text { Cary (Middle } \\
\text { Wisconsin) } \\
\text { Tazewell (Early } \\
\text { Wisconsin) } \\
\text { Iowan }\end{array}$ \\
\hline
\end{tabular}

In Iowa, only the Iowan and Mankato substages of the Wisconsin are present. Separating the Iowan drift from the Mankato drift is the Peorian loess which is related closely in age to the Iowan. The name Peorian in Iowa is now used for the widespread loess which lies on the Iowan drift and around its borders, and beneath the Mankato drift. The Peorian is no longer an interglacial stage but an intraglacial substage. The present classification of the Wisconsin age (stage) in Iowa is as follows:

\begin{tabular}{l|l|l}
\hline Epoch (series) & \multicolumn{1}{|c}{ Age (stage) } & \multicolumn{1}{|c}{ Subage (substage) } \\
\cline { 2 - 3 } Eldoran & $\begin{array}{l}\text { Recent } \\
\text { Wisconsin }\end{array}$ & $\begin{array}{l}\text { Mankato } \\
\text { Peorian } \\
\text { Iowan }\end{array}$ \\
\hline
\end{tabular}

coreighton, M. M., The naming of the subdivigions of the Wisconsin glacial age: Science, new ner., vol. 77, p. 168, 1938.

alKay, G. F., and Leighton, M. M. The Eldoran epoch of the Pleistocene period: Geol. Soc. America Bull., vol. 44, pp. 669-673, 1933 . 
THE IOWAN GLACIAL SUBAGE (SUBSTAGE)

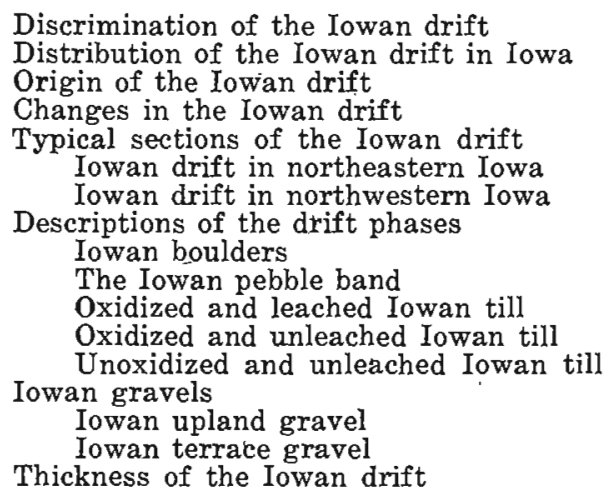

\section{Discrimination of the Iowan Drift}

For many years the Iowan drift has been the subject of much controversy. At times, its very existence has been questioned and much discussion has taken place as to its relationships. By some geologists, the Iowan has been interpreted to be closely related in age to the Illinoian drift, and other geologists have contended that the Iowan drift is much younger than the Illinoian drift and is closely related to the Wisconsin drift.

Since some geologists are not yet convinced that the "Iowan problem" has been solved, it would seem desirable to present at this time a brief history of present day viewpoints. Much of this history has been presented in papers already published. 32

Previous to $1880 \mathrm{McGee}$ had found evidence of two tills in northeastern Iowa, and in $1881 \mathrm{he}^{53}$ referred to them as the Upper Till and the Lower Till, each having its own distinctive characteristics. In some places his Upper Till was the surface till and in other places the Lower Till was at the surface. He was able to map both the tills areally. Where both tills were present in a section they were separated, in many places, by a forest bed or its stratigraphic equivalent, "hardpan" or "gumbo," which he stated was the modified upper portion of his Lower Till. At this time, McGee interpret-

\footnotetext{
${ }^{62} \mathrm{Kay}, \mathrm{G}$. F., Pre-nlinoian Pleistocene geology of Iowa: Iowa Geol. Survey, vol. 84, pp. 70134. 1929.

Kay, G. F., The relative ages of the Iowan and Illinoian drift sheets: Am. Jour. Sci., 5th ser., vol. 16, pp. $497-518,1928$.

Kay, G. F., The relative ages of the Iowan and Wisconsin drift sheets: Am. Jour. Sci., 5th ser., vol." 20 , pp. 158-172, 1981 .

Kay, G. F., Classification and duration of the Pleistocene period: Geol. Soc. America Bull:

vol. 42, pp. 425-466, 1931 . pp. $453-464,1939$

SMcGee, $W J$. The re'ations between zeology and agriculture: Iowa Horticultural Soc. Trans, 16, pp. 227-240, 1881.
} 
ed the widespread loess of northeastern Iowa as being equivalent in age to his Upper Till. In his final report on northeastern Iowa, based upon investigations which extended over many years, $\mathrm{McGee}^{54}$ described in detail the topographic and lithologic character, the stratigraphic relations, and the geographic extent of his Upper Till and his Lower Till. He pointed out that his Upper Till was younger than the gumbo-surfaced drift (present Kansan drift) of southern Iowa, and older than the till of the Des Moines lobe (present Wisconsin drift). McGee did not differentiate in northeastern Iowa a third drift (present Nebraskan drift) which has no mappable surface distribution within his area but which has been exposed in a few places within his area, in railroad cuts and in road cuts, and has been penetrated in well drillings.

The name East Iowan was applied to McGee's Upper Till after Chamberlin ${ }^{55}$ had given this name to the younger of two tills at Afton Junction. In explanation of the term East Iowan he stated on page 760, that "the designation East Iowan Formation is chosen because it has been most carefully worked out by Mr. McGee in northeastern Iowa and there displays its most distinctive features." The name was later shortened to Iowan. Calvin and his associates studied in detail and mapped with little difficulty the Iowan till (Upper Till) in many counties in McGee's area. ${ }^{58}$

In the year 1899 Calvin $^{57}$ published a paper in which he described fully the features of the Iowan drift which differentiate it from the other drift sheets of the Mississippi Valley. The paper refers to many aspects of the Iowan, including (1) the origin of the name Iowan; (2) the area occupied by the Iowan drift sheet; (3) the characteristics of the Iowan drift-the topography, color and composition of the till, its boulders, etc.; (4) relation of the Iowan to the "Forest Bed" of northeastern Iowa; (5) comparison of the Iowan with the Kansan, the Illinoian and the Wisconsin tills; and (6). the Iowan margin, including a discussion of its sinuosities and digitations, the loess ridges along its margin, etc.

By the beginning of the present century there was general agreement among the geologists who had studied in Iowa and adjacent states that the evidence justified the interpretation that Pleistocene history had been long and complex, embracing five glacial and four

\footnotetext{
${ }^{5}$ McGee, W J, The Pleistocene history of northeastern Iowa: U. S. Geol. Survey 11th Ann. Rept., pp. 195-568, 1891.

shamberlin, T. C.. in James Geikie, The great ice age, pp. 753-764, 1894

soKay, G. F., and Apfel, E: T., Pre-Illinoian Pleistocene geology of Iowa: Iowa Geol. Survey, vol. 34 , footnote, p. 78,1929 .

"Talvin, Samuel, The Iowan drift: Geol. Soc. America Bull, vol. 10, pp. 107-120, 1899.
} 
interglacial ages, each of which had been described and named. The recognized classification was as follows:

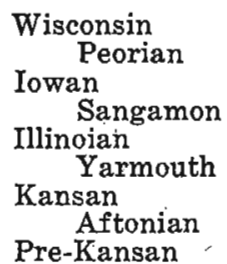

The Iowan drift sheet was interpreted at this time to be related closely in age to the Wisconsin drift sheet, and the widespread loess was called Iowan loess because of its relationship in origin and in age to the Iowan drift. It was at about this time that the loess was being interpreted as eolian rather than fluvio-glacial in origin. Soon the loess, on account of the fossils it contains, was interpreted to be not contemporaneous with the Iowan drift but somewhat later in age than the Iowan. With this change in interpretation the loess began to be called the Peorian loess. It had been deposited in the short interglacial age between the Iowan and Wisconsin glacial ages.

The published record shows clearly that at this time-about the year 1900-this classification had the approval of all the students of glacial and interglacial deposits of the Mississippi Valley-the classic area.

A few years later, the reality of Iowan drift began to be questioned. Leverett, ${ }^{58}$ in a paper in which he discussed the application of weathering and erosion to the correlation of drifts, expressed the view that the topography of the Iowan area in northeastern Iowa was of the erosional type such as characterizes the Kansan drift but that in northeastern Iowa tabular divides were lacking and none of the drift was fresh. He believed that filling of the valleys by slope wash in the Iowan area accounted for the differences in topography of this area and that of the Kansan of southern Iowa. Leverett's skepticism of the Iowan followed field study in the Iowan area, one of the objects of which study was to determine whether or not the Iowan drift was in reality Illinoian drift from the Keewatin field. He concluded that the surface material was not different from the weathered Kansan drift and that if any post-Kansan drift was present, it was probably of Illinoian age. In a later paper, Leverett, ${ }^{\text {g }}$

\footnotetext{
${ }^{60}$ Leverett, Frank, Weathering and erosion as time measures: Am. Jour. Sci., vol. 27, pD $349-368,1909$.

oLeverett, Frank, Comparison of North American and European glacial deposits : Zeitseh Gletscherkunde, B. 4, pp. 241-285, 32i-342, 1910.
} 
in referring to the Iowan drift, used the expression "so-called Iowan of the Keewatin field (Illinoian)."

Two main questions have been at the center of attacks on the Iowan: (1) Is there an Iowan drift? and, (2) Does the Iowan drift belong to the Illinoian glacial stage?

After the death of Calvin in 1911 it. seemed highly desirable to have a review of the evidence bearing upon the Iowan problem and hence, with the hope that a satisfactory solution to the question in controversy might be reached, George F. Kay, Calvin's successor as State Geologist of lowa, asked the United States Geological Survey to undertake the investigation in cooperation with the Iowa Geological Survey. It was agreed that W. C. Alden of the Federal Survey should be assisted by M. M. Leighton of the Iowa Survey. Field work was carried forward during two seasons and in the office careful study was given to published and unpublished material related to the Iowan problem. The results of the investigations of Alden and Leighton were published in Volume 26 of the Annual Reports of the Iowa Geological Survey. ${ }^{80}$ In the Introduction to this report, page 56 , it is stated : "It is a pleasure to report that the conclusion has been reached that there
is what seems to the writers to be good evidence of the presence of a post-
Kansan drift sheet in northeastern Iowa and that this drift appears to be
older than the Wisconsin and younger than the Illinoian drift. The writers
are, therefore, in the main in agreement with the late State Geologist, Dr.
Samuel Calvin, in regard to the Iowan drift. There is, therefore, warrant for
continued use of Iowan drift and Iowan, stage of glaciation as major sub-
divisions of the Pleistocene classification."

The reasons for their judgment are presented fully in this paper. In connection with the discussion of the age of the Iowan drift, Alden and Leighton presented evidence for their belief that the Iowan drift is a distinct drift from the Illinoian drift. They stated :

\begin{abstract}
"From these various observations it is evident that the Illinoian drift has been modified much more by weathering and erosion than has the Iowan. It also appears that most of the modification occurred prior to the formation of the main deposit of loess. It appears clear therefore that the Iowan drift is entirely distinct from and considerably younger than the Illinoian drift."
\end{abstract}

In 1923 Leverett, in a letter written to T. C. Chamberlin, W. C. Alden, M. M. Leighton, and G. F. Kay, with regard to an apporpriate name to be given to the loess overlying the Iowan and Illinoian tills, stated: "I still regard the occurrence of a drift such as outlined by Calvin (i. e., Iowan drift) as unsettled." Since Leverett had not been in northeastern Iowa for several years prior to the

\footnotetext{
${ }^{\circ 0} \mathrm{AIden}, \mathrm{W}$. C., and Leighton, M. M., The Iowán drift, a review of the evidences of the Iowan stage of glaciation: Iowa Geol. Survey, vol. 26, pp. 49-212, 1917.
} 
time this statement was made, and hence had not seen the strong evidence in favor of the Iowan drift which had been made available for study in the many road cuts and other exposures which were made in connection with the new road grading within the Iowan area, Kay invited Leverett to accompany him into northeastern Iowa in the summer of 1925. He accepted the invitation and together they examined some of the most significant exposures within the Iowan area. Paul MacClintock, then of the University of Chicago, and Kay's assistant, E. T. Apfel, accompanied them. Agreement of interpretation was reached on all important matters with the exception of the significance of the pebble band on the Iowan till. Leverett contended that the pebble band was the result chiefly of erosion by running water and that much time had been involved in its formation. He favored the view that the till on which the pebble band had been formed was the result of an ice sheet from the Keewatin field and equivalent in age to a late phase of the Illinoian drift. He was of the opinion that the time between the retreat of the ice from the Iowan area and the deposition of the overlying loess was comparable to the time between the retreat of the Illinoian ice from southeasterm Iow, a and the deposition of the loess overlying the Illinoian drift, which loess is of the same age as that overlying the Iowan drift. He would make the Iowan drift the product of a late phase of the Illinoian stage of glaciation and would give the name Sangamon to the interval between the Iowan drift and the overlying loess as well as to the interval between the Illinoian drift and the loess which overlies it.

As a result of evidence seen and discussed during this field conference; Leverett did not again question the existence of a postKansan drift in northeasterm Iowa, but the age of the drift continued to be a subject of difference of interpretation. The evidence which had been published by Calvin, and later by Alden and Leighton, was emphasized in support of the view that the Iowan drift is young in comparison with the Illinoian and hence should be retained as a separate glacial stage in Pleistocene classification. Moreover, it was pointed out by Kay that the strongest argument in support of the Iowan drift being younger than the Illinoian drift is the presence over wide areas in southeastern Iowa and Illinois of from 3 to 4 feet of Illinoian gumbotil on the Illinoian till and beneath the Peorian loess, whereas in the Iowa area the Iowan till is leached only to a depth of a few feet and is so young comparatively that gumbotil has not yet been developed anywhere on this till, not even 
where the topographic position of the Iowan till is very similar to the topographic position of the Illinoian till, e. g., on the uplands.

The interpretation of Leverett as expressed by him in the field conference in $1925^{\prime}$ was presented in $1926^{\prime}$ in a paper read before the American Philosophical Society in Philadelphia. ${ }^{61}$ A part of this paper deals with "the Iowan drift of northeastern Iowa and its probable correlatives." This part of Leverett's paper called forth a reply by Kay. ${ }^{62}$ From this paper the following quotations are made:

"Before presenting his reasons for favoring the correlation of the Iowan drift with the Illinoian drift Leverett states: "If it is granted that the Iowan drift stands for a glacial stage between the Illinoian and Wisconsin stages there were five glacial stages in America.' The vital question then is, is the evidence which is favorable to the correlation of the Iowan with the Illinoian of sufficient weight to offset the strong evidence in support of the Iowan and Illinoian being considered as independent stages?

"Mr. Leverett in his paper calls to the reader's attention the fact that for some time after the Iowan drift was differentiated from the Kansan drift in northeastern Iowa the opinion prevailed that the widespread loess of the area was aqueous in origin and was of the same age as the Iowan. However, in this connection it.should not be forgotten that as early as 1904 the view that was accepted quite generally in Iowa was that the loess is not aqueous but is eolian in origin. From that time to the present it has been the judgment of all persons connected with the Iowa Geological Survey, and others, that the loess is not Iowan in age but was deposited a comparatively short time after the retreat of the Iowan ice. This, was the view of Calvin in the later years of his life, and the view which was advanced by Alden and Leighton in their report on the Iowan drift in the 1915 Annual Report of the Iowa Geological Survey.

"It is to the interpretation that the loess overlying the Iowan till was deposited but a short time after the retreat of the Iowan ice sheet that Leverett takes exception. It is here that he finds his chief basis for suggesting the correlation of the Iowan till with the Illinoian till. He emphasized the significance of the pebble band which separates the Iowan till from the overlying loess. The pebble band which was seen by Leverett, MacClintock, Apfel and the writer in the summer of 1925 is described in his paper in some detail. Here he states the judgments which he expressed in the field conference to which reference has already been made. He believes, that the pebble band is the result of slope wash rather than of wind action. He thinks that a great length of time was necessary for the development of this pebble band, and hence the loess overlying the pebble band must be very much 'younger' than the Iowan till upon which the pebble band lies.

"Leverett states in his paper that the Iowan drift !lies wholly within the limits of what has been termed the Keewatin field of glaciation.' And then after having presented some facts with regard to the growth of ice sheets, particularly with reference to the Wisconsin, he applies the same principles to the method of growth of the Illinoian. He states 'It seems but natural that westward growth such as we know affected the Wisconsin ice sheet should also have occurred in the Illinoian stage and given the ice movement that brought in the Iowan drift.' Here we have his theoretical grounds for thinking that the Iowan drift should be correlated with the Illinoian.

"Mr. Leverett gives but brief consideration to the evidence that has been presented by Calvin, Alden and Leighton, the writer, and others in support of the interpretation that the Iowan and Illinoian glacial stages.were widely separated in age. He attempts briefly to explain the lack of gumbotil on the

oLeverett, Frank, The Pleistocene glacial stages: Were there more than four?: Am. Phil. Soo. Proc.; vol. 65, no. 2, 1926.

azKay, G. F., The relative ages of the Iowan and Ilinolan drift sheets: Am. Jour. Scl., vol. 16. pp. $511-514,1028$. 
Iowan and in places on the Kansan. The absence of gumbotil on the Iowan could be explained, he believes, by the lack of summit flats. In this connection it should be stated that some parts of the Iowan area have the. same topographic position and character as the upland flats of the Illinoian area upon which the gumbotil is found. His reference to lack of gumbotil on the Kansan in northwestern Iowa is without significance since he failed to recognize that the writer and others have, presented field evidence to warrant the interpretation that gumbotil was developed on the Kansan till in that area, and that in connection with the development of the present topography in that area the gumbotil was eroded, leaving the oxidized and unleached Kansan till with much secondary calcium carbonate at the surface. 63

"In closing his discussion of the Iowan in relation to the Illinoian Leverett states:

"In view of all the features of the Iowan drift, taken in connection with the fact that it stands as the third drift of the western district, as the Illinoian does of the eastern, and that each district has but four drifts, the writer raises the question whether there really were more than four Pleistocene glacial stages in North America, or whether the Iowan drift should be regarded as a late phase of the third glacial stage. Features of the Iowan drift and its relation to the loess seem to demand further critical field study.'

"It must be kept clearly in mind that Leverett now is suggesting four glacial stages instead of five, not, because he questions the existence of the Iowan drift as he did until recently, but for the reason that he believes the Iowan drift may be a late phase of the Illinoian and hence should be correlated with that drift sheet. The task therefore is no longer that of proving whether or not there is an Iowan drift, but of showing even more definitely than has been done thus far the relations of the Iowan drift to the Illinoian drift."

Kay pointed out in his paper that the chief arguments against the correlation of the Iowan with the Illinoian are (1) the occurrence of gumbotil on the Illinoian till in contrast with no gumbotil on the Iowan till even within those parts of the Iowan area which have the same topographic position and character as the upland flats of the Illinoian area upon which the gumbotil is found; and (2) the presence of two loesses on the Illinoian drift whereas there is only one loess on the Iowan, this loess on the Iowan being the widespread Peorian loess, the younger of the two loesses on the Illinoian. Evidence was presented to support the interpretation that the Peorian loess was deposited very soon after the retreat of the Iowan ice sheet but a long time after the retreat of the Illinoian ice sheet. This interval between the time of deposition of the Illinoian till and the time of deposition of the Peorian loess was of sufficient duration to account for (a) the formation of a gumbotil more than 3 feet thick by the weathering. of unoxidized and unleached Illinoian till; (b) the deposition of a loess, the older loess, on the gumbotil and on the eroded surfaces of the Illinoian till; and (c) the leaching of this older lobess in places to a depth of several feet.

\footnotetext{
orKay, G. F., Pleistocene deposits between Manilla in Crawford County and Coon Rapids in Carroll County: Iowa Geol. Survey, vol, 26, pp. 218-219, 1917.

Carman, J. E., Further studies on the Pleistocene geology of northwestern Iowa: Iowa Geol. Survey, vol 35 , pp. 108-111, 1931 .
} 
The "Iowan problem" continued to occupy the central place among discussions of the Pleistocene of the Mississippi Valley. Leverett ${ }^{64}$ in 1930, in his retiring address as Vice-President of Section E, Geology and Geography, of the American Association for the Advancement of Science, made the following statement:

"The Iowan, or third drift of the region west of the Driftless Area of the Upper Mississippi Valley, is of such a problematical character that the students who have examined it have been unable thus far to come to an agreement as to its place and rank in the glacial series ..... The principal question now in dispute is the relation of the Iowan to the Illinoian drift. Chamberlin and Leverett in recent years have referred it tentatively to the same glacial stage as the Illinoian drift. But Kay and his associates on the Iowa Geological Survey and Alden of the U. S. Geological Survey hold to an early idea that it is the product of a distinct glacial stage standing between the Illinoian and Wisconsin. They grant, however, that there does not seen to be any equivalent of the Iowan drift in the district east of the Mississippi Valley. They thus restrict the Illinoian drift to the Labrador part of the Laurentide field of glaciation, and the Iowan to the Keewatin part, which seems a very doubtful and unnatural restriction.

"The reference of the Iowan drift to a later glacial stage than the Illinoian is based by these students on the lack of a gumbotil deposit on its surface, such as is found on neighboring parts of the Illinoian drift. They also maintain that the erosion and weathering and especially the leaching of lime is less on the Iowan drift. Recently $K$ ay has announced the presence of a loess deposit on the Illinoian drift that seems to him to correlate with a loess that underlies the Iowan drift. The absence of gumbotil on the Iowan drift seems to be due to a lack of favorable conditions for its development-rather than to a lack of time. It is hoped that further field study may clear up the remaining points of difference."

\section{In a later paper Leverett ${ }^{65}$ states :}

"An early interpretation that the Iowan is a distinct glacial stage falling between the Illinoian and Wisconsin glacial stages is still stoutly adhered to by several glacialists, but the present writer and also T. C. Chamberlin have expressed the view that the-Iowan may stand as the western or Keewatin phase of the same glacial stage as the lllinoian and have a similar relation to it that the Late Wisconsin drift has to the Early Wisconsin."

In these two papers, Leverett's correlation of the Iowan with the Illinoian seems to be based to a greater extent on theoretical grounds rather than upon field evidence.

In 1939 , Leverett's latest paper ${ }^{66}$ dealing with the Iowan problem appeared in the Journal of Geology. It is entitled "The Place of the Iowan Drift." In this paper he refers to a statement which he had made in a report published in $1932 .{ }^{87}$ The statement is as follows :

"The Iowan drift is so scantyoand its limits in northeastern Iowa, as well as in southeastern Minnesota, are so ill-defined, that its extent is still an

\footnotetext{
aLeverett, Frank, Problems of the glacia'ist: Science, new ser.. קol. 57, 1930.

Leverett, Frank, Relative length of Pleistocene glacial and interglacial stages: Science, new ser. vol. 72, p. 194, 1930 .

Leverett, Frank, The place of the Iowan drift: Jour. Geology, vol. 47, pp. 398-407, 1939.

or Leverett, Frank, and Sardeson, F. W., Quaternary geology of Minnesota and parts of adjacent states : U. S. Geol. Survey Prof. Paper 161, p. 28, 1932.
} 
open question. There seems also to be an entire absence of recessional moraines. These conditions strongly suggest a stagnation or nearly complete cessation of movement in the Iowan ice sheet soon after it had reached its culmination position. The belts of gravelly ridges, which generally have a trend toward the border of the drift instead of parallel with it, are consistent with and seem to support the interpretation of a stagnation of ice movement'."

On page 35 of the same report the following statement appears in reference to the part of the Iowan drift exposed west of the Des Moines lobe of late Wisconsin drift:

"Although the lowan drift in this district west of the Des Moines lobe of Wisconsin drift has a more definite border than that east of this lobe, it seems to have no recessional moraines and is generally a very scanty deposit. These conditions make it seem probable that this part of the Iowan ice sheet also became stagnant soon after reaching its culminating position."

His generalization with regard to the statement just made is as follows:

"For the consideration of glacial students I am now presenting the view that a condition of stagnation in an ice sheet is more natural for a waning or dying-out phase of a glacial stage than would be natural for the opening phase of a glacial stage. If the Iowan is a late phase of the Illinoian glacial stage, as I have maintained in my latest report, there seems nothing surprising to have it reach a stagnant condition. But, if it comes as the opening phase of the Wisconsin glacial stage, it seems to me unnatural for it to become stagnant."

In this paper he presents field evidence from Minnesota and Wisconsin and states that he "believes that the matter under discussion can be better worked out in Minnesota and Wisconsin than in Iowa," and suggests that those areas be carefully. studied before final judgments are reached as to the relationships of the Iowan drift.

Leverett further states:

"A few words seem appropriate on the efforts of certain glacial students to give finality to the intrepretation that the. Iowan drift is an early Wisconsin product and to practically exclude the alternative interpretation referring it to the Illinoian glacial stage. This is particularly unfortunate since it may be reproduced in textbooks and books intended for the general reader."

". . If then in Table. 1 the names in parentheses, added by the writer, were used, this slight addition might make a presentation of the alternative classification unnecessary."

\section{TABLE I}

Wisconsin glacial

Mankato drift (late Wisconsin)

Cary drift (middle Wisconsin)

Tazewell loess

3 Tazewell drift (early Wisconsin)

Sangamon interglacial

Iowan drift (possibly Illinoian)

Illinoian glacial (perhaps includ-

ing the lowan drift)

Yarmouth interglacial

Kansan glaeial

Aftonian interglacial

Nebraskan glacial 


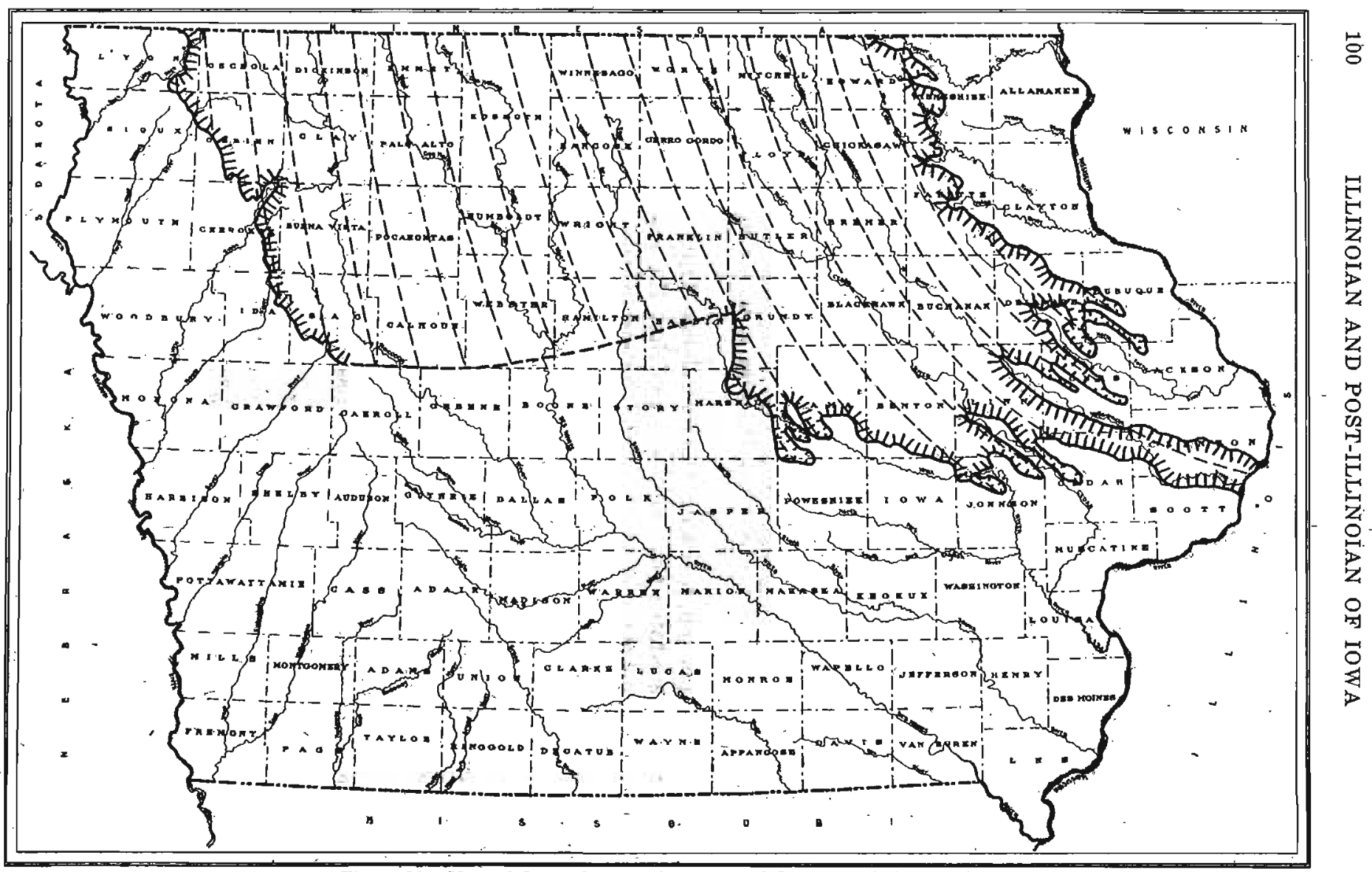

Figure 26. Map of Iowa showing the extent of Iowan glaciation in the state. 
By way of summary, it perhaps should be stated that a study of the records shows that of the several geologists who have studied the Iowan drift in the field in Iowa and adjacent areas, Leverett is the only geologist in recent years who has been maintaining that the Iowan is closely related to the Illinoian. Other geologists have presented evidence to show that the Iowain is more closely related to the Wisconsin than the Illinoian, and Kay and Leighton, as has already been stated, have included the Iowan as the oldest substage of the Wisconsin stage.*

\section{Distribution of the Iowan Drift in Iowa}

The characteristic topography of the Iowan drift makes its presence in an area quite readily determinable. The uneroded portions of the Kansan drift plain remain as flat, tabular areas. The uneroded Iowan plain is in many places gently rolling but elsewhere, for example in Mitchell and Worth counties and adjacent Iowan areas, the topography shows as flat, level upland surfaces as are presented in places by the Kansan and Mankato upland plains.

The valleys of the Iowan drift region also have a characteristic appearance. In contrast with the steep walls of the gullies and many of the larger valleys of the Kansan area the Iowan valleys present gentle slopes, except where they are rockbound, and many of them grade almost indefinably into the drift plain.

The Iowan drift originally had a surface distribution nearly across northern Iowa (fig. 26). It was by far the most extensive in Iowa of the three later drift sheets and it spread out within one or two counties of the bounding rivers on both east and west margins of the state. It probably entirely covered about 25 counties and occupied parts of 20 others. But the latest advance of the Wisconsin ice, the Mankato, (fig. 76), in its extension down the valley of Des Moines River, covered nearly one-half of the Iowan drift sheet and left at the surface the Iowan area including more than 20 counties on its eastern side, and a much smaller roughly triangular area exterding from southern Sac County northward into Minnesota on its western side. This western area has been so thoroughly described by Carman ${ }^{68}$ that little can be added here. Carman states that:

"It is believed that before the deposition of the Iowan drift this region had an erosional topography developed on the Kansan drift plain. . . These pre-

*While this paper was in press, Leverett stated in the Journal of Geology, vol. 50, NovemberDecember, 1942, "The lowan drift of lowa and Minnesota I now regard as a Keewatin product of Early Wisconsin rather than of Late Ilinoian age."

${ }^{6}$ Carman, J. E., Further. studies on the Pleistocene geology of northwestern Towa: Iowa Geol. Survey, vol. 35, pp. $39-48,1931$. 
Iowan features were not completely obliterated by the Iowan drift sheet and still remain as the greater relief features of the region. Upon these larger features the Iowan drift sheet superposed a glacial topography with minor constructional features making uneven billowy slopes."

Carman is here writing of the area west of the Mankato lobe of the Wisconsin drift sheet. Because of the probable fact that northwestern Iowa was elevated somewhat more than were other parts of the state after the development of the Kansan gumbotil, it may be that the Kansan drift plain in this region had been eroded nearer to a peneplane before the coming of the Iowan ice than had the Kansan plain elsewhere. This would tend to make the surface of the Iowan drift somewhat smoother in western Iowa than in the eastern area.

A remarkable feature of the southeastern margin of the Iowan drift sheet is the series of lobes or prolongations that extend out from the general front, in some cases for many miles. These appear to be parallel with the main line of the ice advance; that is, they stretch southeastwardly from the main drift sheet: A few small but well-defined lobes are present: in Winneshiek and Fayette counties, but the largest are found from Dubuque to Johnson counties, with a shorter series in Tama and Marshall counties. Several features are worthy of mention. Those parts of the margin that are parallel to the direction of ice movement, as the border across parts of Fayette, Clayton and Delaware counties and that across Benton County, are free from lobes. The lobes do not occupy the valleys but either lie on the uplands or extend across upland and valley indiscriminately. These lobes can hardly be erosion remnants, both because of their form and position and because of the comparative freedom from erosion of the Iowan drift.

Another unusual feature of the Iowan drift area is the presence of a number of inliers or islands of Kansan drift here and there over the Iowan plain. These islands show typical rugged Kansan topography, are heavily loess-covered and usually stand above the surrounding Iowan plain. They seem to be indicative of the thinness of the Iowan drift and also to suggest that the Iowan ice was not very strongly erosive as it crossed the Kansan plain of northern Iowa.

The Iowan drift is not everywhere a thin veneer on the Kansan erosional surface. In places, the Iowan displays constructional features having a thickness up to 60 feet as measured from neighboring Kansan gumbotil levels. Thin loess may or may not cover these mounds of drift, but when present it does not constitute an appreciable part of the thickness. 
The whole assemblage of features of the Iowan drift plain indicates that its topography is constructional rather than erosional, that it still retains the features impressed on it by the erosional topography of the underlying Kansan drift and by the ice sheet that brought it down and laid it over the Kansan surface.

A good deal of the margin of the eastern area of the İowan drift can not be located exactly because it is concealed by the thick layer of loess that is piled on it. Inward from the margin this loess is thin, in most counties not over 1 or 2 -feet in thickness, although in a few localities its thickness may reach 4 or 5 feet. Outward from the margin the thickness is much greater, reaching 50 feet or more in some places near the edge. However, it thins rather abruptly outward and within a few miles is only a few feet thick.

In the Kay and A'pfel report is a map ${ }^{69}$ showing by patterns the main areas of distinct topographic development in Iowa. On this map the Iowan areas are named the "eastern area of drift mantled erosional topography", and the "western area of drift mantled erosional topography" (fig. 27). With regard to the eastern area, the following statement on page 51 is made:

"The eastern Iowan area occupies the greater part of the northeastern quarter of the state. The area includes all or parts of twenty-five counties as is shown in figure 26 . It is roughly quadrilateral in shape.

"The boundaries of the eastern drift mantled area are fairly definite. Most of the west line lies along the morainal margins of the Wisconsin drift, -the east, south and southwest sides are bordered by thick loess and sand deposits, and the Minnesota-Iowa state line marks the north edge. The drift mantle of this is Iowan drift; it lies on an eroded Kansan drift surface.

"From a topographic standpoint this area is more typically 'gently rolling' than any other part of the state, and there is no distinct topographic datum plane to which the relief can be related as. in southern Iowa. The river valleys are in most places fairly broad in relation to the streams: in them, and instead of these broad valleys having wide flood-plains, many of them have concave profiles. Some writers have stated that the streams flow in 'sags' which extend for miles along the stream courses, the sags being best explained as partly filled broad valleys. The flood-plains in some places at least are not built of alluvial materials, but are drift flats appeairing now probably much as they did. when the ice-sheet left them.

"The broad sags are bordered by lines of hills, in some places with very gentle slopes, and in other places with steep slopes. Nowhere is the relief locally great. Although here and there the hills look somewhat formidable from a distance, it is seen upon close approach that the slopes are gentle. As a rule, the relief is less than 100 feet; but even such relief is sufficient to give somewhat commanding elevations in the landscapes. The divides are usually undifferentiated either by prominence or continuity from the hills which lie along the stream valleys.

"In parts of this drift mantled area the relief is very slight, and the surface for mile after mile appears to the eye to be almost level. All parts are drained, however; no lakes exist, but small ponds are formed in depressions during heavy or prolonged rainfall, and formerly extensive areas were boggy during wet seasons. The slight relief which is characteristic of these

Bókay, G. F., and Apfel, E. T., The pre-Illinoian Pleistocene geology of lowa: Iowa Geol. Survey, vol. 34, p. 37,1928 . 


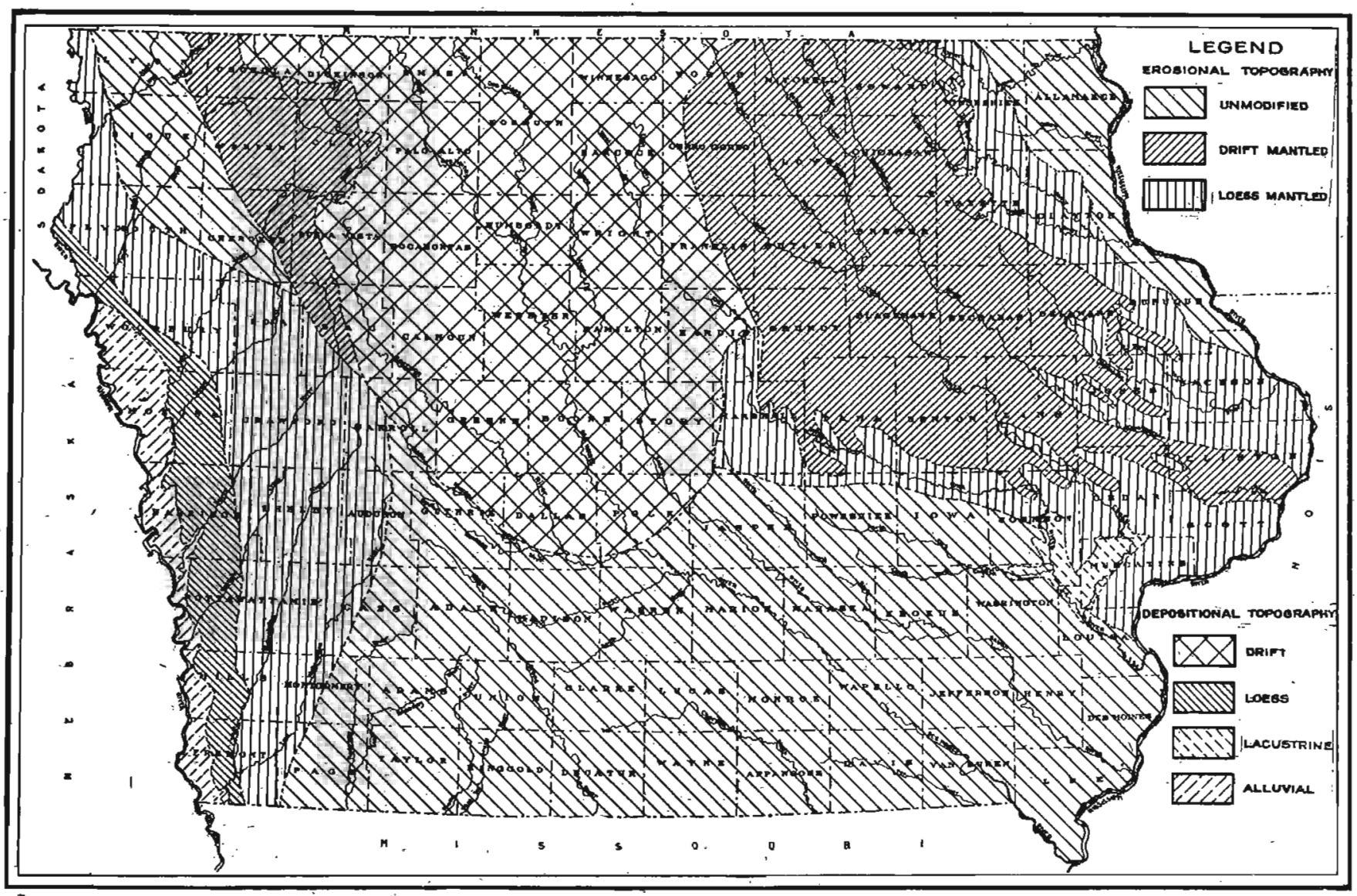

Figure 27. Map of Iowa showing by patterns the main areas of distinctive topographic development in the state 
flat areas cannot be explained satisfactorily as being the result of erosional agencies alone, but rather as having been made by the deposition of material distributed irregularly over broad tabular divides remaining on an erosional surface. The broadly concave valleys the inconspicuous divides, and the swells on drained level stretches indicate a depositional modification of a normal erosional surface. In accord with this interpretation is the presence of numerous immense boulders and many boulders of less size which are not distributed in relation to major drainage lines, but which occur with little relation to the topography.

"The drift mantled area has within it many outcrops of indurated rocks. These are most prevalent along the drainage lines; in places they are the walls of gorges, and in other places they outcrop only in the beds of streams. To a very limited extent only have these indurated rocks been effective in determining the development of the present topography. They are spectacular features, but outcrops are restricted, and hence they have no important areal or topographic significance."

The statement by Kay and Apfel on page 53 with regard to the northwestern area is as follows:

"The northwestern Iowan area of drift mantled erosional topography in-
cludes nine counties; it is about twice as long as it is wide, with the long
axis extending a little east of south from the Minnesota line, as shown in
figure 26 . The east boundary is strongly bowed eastward following the edge
of the Wisconsin drift, whereas the west boundary is bowed slightly to the
west. The drift in this area, as in the eastern drift mantled erosional area,
is Iowan drift lying on an eroded Kansan drift surface.
"The northwestern area differs from the northeastern area in that the
drift mantle in the northwestern area was deposited on a surface which had
been reduced by erosion not only to a mature stage but to a stage well ad-
vanced toward old age. Such a surface has less conspicuous relief than a
mature erosional surface and when covered by a mantle the new surface
is likely to obscure more of the characteristics of the underlying erosional
surface than in a region where the drift mantle is deposited on a mature
erosional topography. The more the underlying erosional features are ob-
scured the more apparent are the effects of the mantle. In the northwestern
Iowan area the valleys and their tributaries do not have the distinctive den-
dritic drainage features characteristic of topographies due to erosion only.
In places the valley wals have been sharpened or smoothed, in other places
spurs due to deposition extend into valleys, and in places there is morainal
topography.

This western area of Iowan drift is covered by several feet of loess, derived largely from the valley of Missouri River to the west. The loess thins to the eastward, and extends beneath the Mankato drift.

\section{Drigin of the Iowan Drift}

The Iowan drift has several distinctive features. It contrasts markedly with other Pleistocene drift sheets in the sinuosities of its till border, its thinness, its distribution in interstream areas and about islands of Kansan topography, its loess relationships, and its burden of enormous, prominently granitic erratics. It is young enough to have escaped, thus far, noticeable stream dissection. Time has been too short for the formation of a gumbotil upon 
the uneroded uplands and leaching has progressed downward for an average depth of not more than $5 \frac{1}{2}$ feet. One must therefore ascribe such differences as are observed in the comparison of the Iowan drift with other Pleistocene drift sheets of Iowa, to original differences.

The load acquired by continental glaciers is a composite of all surface debris and mantle rock which the glacier is able to incorporate by freezing into its mass, by plucking, gouging, and shoving ahead of the ice front. In addition, bedrock is frequently scoured to depths below previous depths of surface weathering, and fresh country rock is added to the load. "Thus, the drift material of any glacier is a resultant of all the materials, both of the surface and the bedrock, of the whole of the area invaded by the ice. In the case of the Iowan drift in Iowa, much of the till deposited is without question of previous glacial origin, having been deposited within, or north of the state, as part of older tills. Since this is true, it might be expected that the Iowan till would noticeably reflect the weathering of that part of its glacial content which was surface material during the Sangamon interval just previous, or for longer periods of time. However, below the depth to which postIowan leaching has taken place, Iowan till is comparable in lime content to the unleached portions of older tills, and like the Illinoian, which moved across the aging surfaces of the Nebraskan and Kansan drift, is on the whole a fresh drift.

That part of the Iowan glacier which invaded the northern half of Iowa is related to the Keewatin center of glaciation, and entered the state almost directly from the north. The prevalent granite erratics are of northern stock, as there is no possible source of such material within the boundaries of Iowa. Early describers of this drift remarked about the predominance of the lighter granitic types over the higher greenstone content of older drifts, particularly the Kansan.

Perhaps those very features of unusual mobility and thinness of the Iowan ice may explain the unusual size and number of erratics, due to the comparative inability to grind to pieces and digest great units of resistant rock.

Whatever may be the conditions which effected the distinctive features of the Iowan drift, the drift materials themselves indicate the heterogeneous sources common to all continental glaciers. These materials have been mixed together and redeposited as the gravelly till, the boulder fields, and the gravel and outwash areas of the Iowan drift. 


\section{Changes in the Iowan Drift}

With the retreat of the Iowan ice from the area it occupied in Iowa, certain changes in the physical and chemical character of the freshly exposed till occurred, produced chiefly by the weathering agencies of oxidation and solution. It is apparent from observations along road cuts through fresh unoxidized and unleached till, that the process of oxidation takes effect immediately upon exposure of a fresh surface, and penetrates with a speed relative to the many chemical and physical factors inherent in the material and surrounding local environment. Thus, the first apparent change in the till would be the yellowish-brown stain of iron oxide which would creep downward into the till with diminishing speed, as the compactness of the deeper till and the surficial oxidation reduced the effectiveness of the process.

Equally quick to begin modifying the till character is the process of solution of the normally high percentage of calcium carbonate in the till. However, this is a much slower process than that of oxidation, and since the retreat of the Iowan ice, removal of the lime content in the till has occurred generally only in the upper 5 $51 / 2$ feet. The penetration of the process of oxidation outstrips that of leaching, such that the normal sequence seen in the Iowan till is as follows :

$$
\begin{aligned}
& \text { Iowan oxidized and leached till } \\
& \text { Iowan oxidized and unleached till } \\
& \text { Iowan unoxidized and unleached till }
\end{aligned}
$$

The depth of leaching on the Iowan, as well as on the Mankato till, is graphically illustrated in figure 28.

The Iowan till lacks the gumbotil phase which has been found on the three older tills. This lack is quite in accord with all evidence pointing to the formation of gumbotil as an extreme product of the same weathering processes described above. With sufficient time, a gumbotil would presumably be formed on the uneroded Iowan surface by continued chemical and physical changes taking place in the already leached and oxidized surficial materials of the Iowan drift.

\section{Typical Sections of the Iowan Drift \\ Iowan Drift in Northeastern Iowa}

The Iowan drift of northeastern Iowa.everywhere lies within the area covered by Kansan drift, with the possibile exception of a narrow overlap of Iowan on Illinoian in northern Scott County. As 


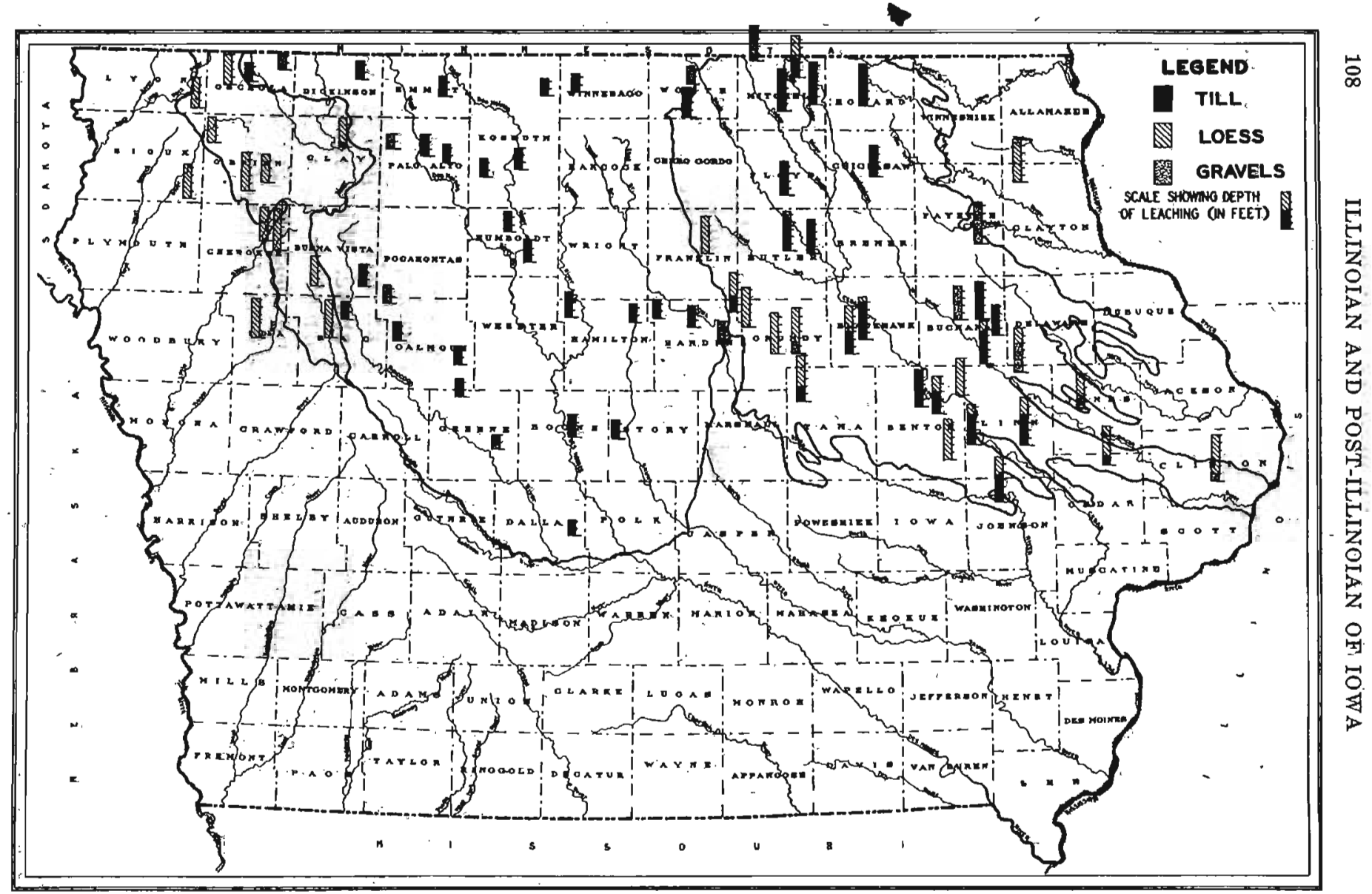
Figure 28. Map of lowa showing by diagram the depths of leaching of calcium carbonate
in materials within the Iowan and Mavikato drift areas of lows. 
a matter of fact, however, the Iowan drift is known to lie on the indurated bedrock or its weathered derivatives, on various phases of Nebraskan drift, on Aftonian deposits, on the different types of Kansan till and gravels, and on the Loveland loess and other kinds of deposits of Buchanan age.

Some examples of Iowan drift lying on bedrock are to be seen in sec. 20, Union Township, (T. 87 N., R. 4 W.), Delaware County, where a rocky knoll projects through the drift; and 3 miles south of Manchester, in the same county, where a group of blocks of Niagaran limestone rises above the drift plain. Iowan till was found lying on Nebraskan gumbotil 2 miles north of Manchester, in the NE $1 / 4$ sec. 17, Delaware Township, (T. 89 N., R. 5 W.). The road cut here showed:

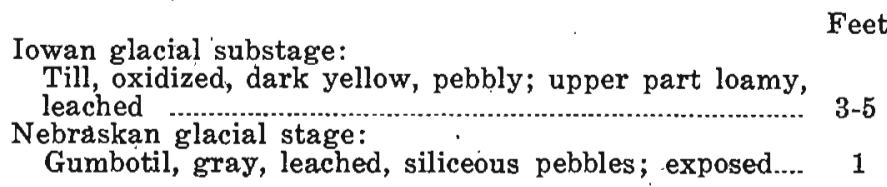

The gumbotil is determined to be Nebraskan by its elevation, which is 985 feet, while Kansan gumbotil not far away is 1042 feet above sea level. The topography surrounding this cut is distinctly Iowan. One-fourth mile south of this cut a pit showed 11 feet of chocolate-colored leached gravels resting on limestone. This gravel lies at the same elevation as the Nebraskan gumbotil and is considered to be of the same age.

One of the best known sections in northeastern Iowa is the cut at Oelwein, (T. 91 N., R. 9 W.), Fayette County, on the Chicago Great Western Railway. This has been visited by many geologists, and it has been described by Kay and Apfel, ${ }^{70}$ and by others. Before slumping it showed Iowan till, Buchanan sand and gravel, Kansan till, Aftonian sand underlain by peat, and Nebraskan till, Some geologists have questioned the reality of the Iowan in this section. It has even been called "graders' dump". But Kay has recently been able to verify the accuracy of the assignment of the upper beds to the Iowan. He was able to make out the following strata in the upper part of the cut, on the south side, where no graders' dump is present:

Iowan glacial substage:

Soil, dark, loamy.

Till, brownish to yellowish, fairly compact, leached...

Feet Inches

Till, oxidized, unleached. Thickness not determinable

5 on account of vegetation on the slope.

70Kay, G. F., and Apfel, E. T., The pre-llinoian Pleigtocene geology of Iowa: Iowa Geol. Survey, vol. 34, pp. 199-200, 1929." 
On the north side a similar section was found beneath the graders' dump. The distinctive Iowan boulder-bearing topography is present to the edges of the cut.

Another very good section was revealed in grading U. S. highway 18 along the north line of sec. 16, Windsor Township, (T. $94 \mathrm{~N}$., R. 9 W.), also in Fayette County. This too was described by Kay and Apfel, on page 230 of the report just cited. It shows a somewhat different succession, including loess and Iowan till, both unleached; Loveland loess, leached; Kansan gumbotil and till, leached. This cut is in the marginal moraine and the hills to the south rise 37 feet above the gumbotil. This is an unusual thickness of Iowan, one rarely found except near the margin.

A section in the middle of the $\mathrm{NE}^{1 / 4}$ sec. 4, Lincoln Township, (T. 98 N., R. 20 W.), Worth County, shows a very complete series of Pleistocene deposits within an unusually short vertical range. The section includes:

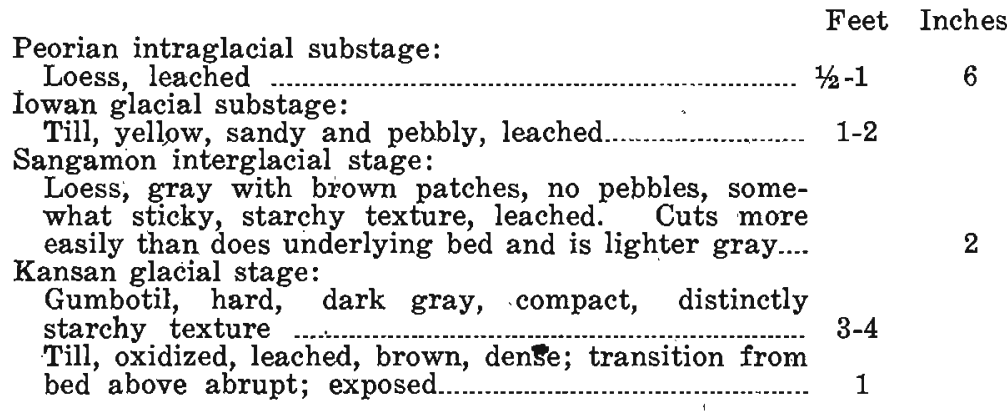

Another section that shows a more nearly normal thickness of Iowan materials is a road cut in the SW $1 / 4$ sec. 3, Polk Township, (T. 86 N., R. 9 W.), Benton County. 'The north side of this cut shows:

Peorian intraglacial substage:

Feet Inches

Sand, yellow, upper 2 feet loess-like.

Iowan glacial substage:

Till, gravelly, oxidized and leached

2

Sangamon interglacial stage:

Loess, gray to drab, iron oxide tubules, leached

Kansan glacial stage:

Gumbotil, very carbonaceous in upper part; exposed 1-3

The gumbotil is exposed for over 100 yards along the base of the cut. On the south side the material above the till is more distinctly loess-like, although it retains its sandy nature.

The thinness of the Iowan drift in the lobes is shown in a road 
cut in the $\mathrm{SE}_{1 / 4}^{1 / \mathrm{SW}} 1 / 4$ sec. 29 , Red Oak Township, (T. 81 N., R. 3 W.), Cedar County. This is 100 yards long and shows:

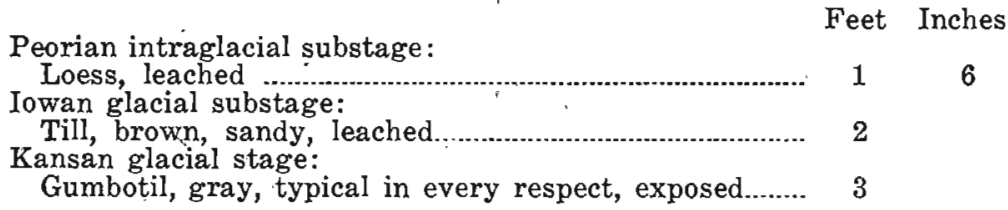

Another section near here that shows the effect of overriding on older materials is in the $\mathrm{SE}^{1 / 4}$ sec. 36, Cass Township, (T. $81 \mathrm{~N}$., R. 4 W.), Cedar County. Here is an upland cut that showed Kansan gumbotil and old leached Buchanan gravels intermingled and contorted for a depth of 5 feet by the Iowan ice. The oxidized and leached Kansan till is exposed beneath the gumbotil. Above the gumbotil and gravels is 4 feet of sandy Iowan till. Where this is intermingled with the gumbotil, lime concretions and scattered calcium carbonate are still present. The topography also indicates that the surface material is Iowan, as it is constructional rather than erosional. The elevation of the gumbotil is about 790 feet. Figure 29 illustrates Iowan drift overlying distinctive Buchanan gravels near Doris, Buchanan County.

Between secs. 30 and 31, Massillon Township, (T. 82 N., R. 1 W.), Cedar County, $2 \frac{1}{2}$ miles east of Clarence, is a shallow cut showing 1 to 3 feet of leached, pebbly Iowan till over Kansan gumbotil and under 2 feet of loess. The interesting point about this section is the fact that the elevation of the gumbotil checked from Clarence proves that the thickness of the Iowan till is at least 45 feet. This is at the south edge of the Clinton lobe of Iowan drift.

A road cut 8 miles north of New Hampton, between the north parts of secs. 31 and 32, Jacksonville Township, (T. 96 N., R. 12 W.), Chickasaw County, shows an interesting section of Iowan that is too thick to be all leached. No loess is evident in the succession, which is as follows:

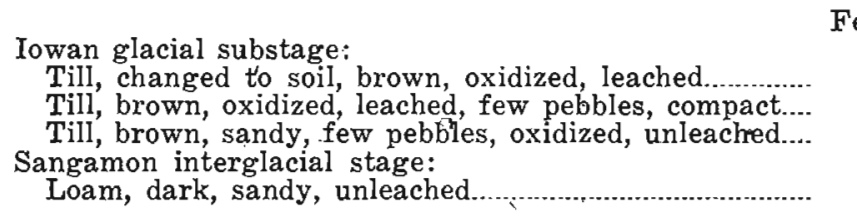

Till, brown, oxidized, leached, few pebbles, compact....

Sangamon interglacial stage:

Feet Inches

1

Across the road, on the west side, the unleached till is filled with secondary lime and below it 4 feet of Kansan gumbotil is exposed.

A section in Clayton County shows Iowan that is in part un- 


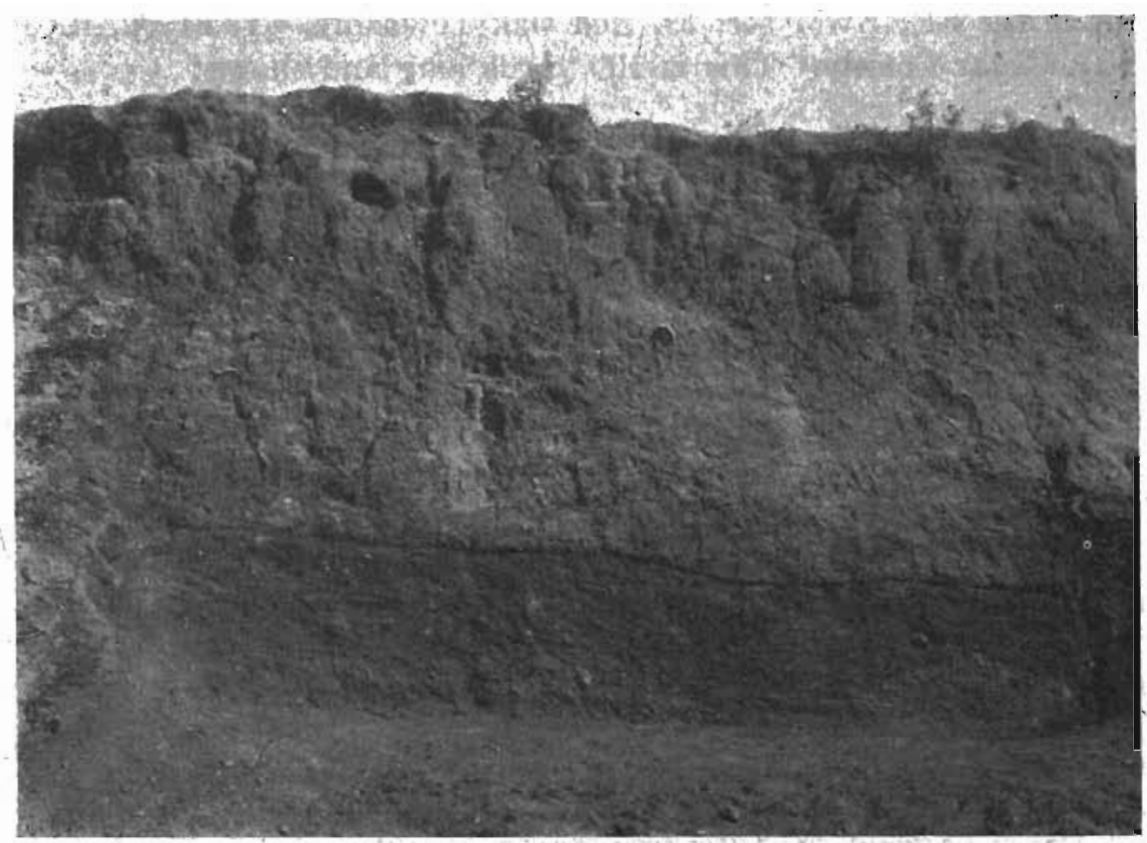

Figure 29. Iowan drift overlying' distinctive Buchanan gravels near Doris, Buchanan Countỳ.

leached, with no older drift exposed. This outcrop is on the north side of the road along the SE1/4 sec. 25, Cass Township, (T. 91 N., R. 6 W.). It showed:

Peorian intraglacial substage:

Feet Inches

Loam and loess-like loam, leached, sandy, dark to brown

Iowan glacial substage:

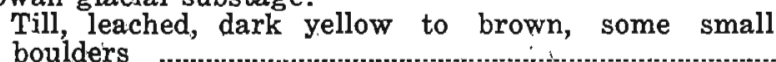

boulders

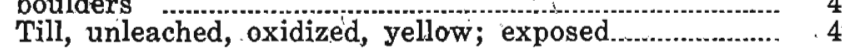

16

A slight pebble band separates the loam and till.

Sections that show Iowan till thick enough to be unoxidized in its lower part are comparatively rare. One such cut was found along the east side of the road, in the $\mathrm{SW}^{1 / 4}$ sec. 28 , Taylor Township, (T. 85 N., R. 10 W.), Benton County. It showed in its deepest part:

Iowan glacial substage:

Feet Inches

Till, brown, sandy to the surface; in places gravelly, yellowish brown to dark brown in color, leached; where till is sandy and gravelly, leaching has progressed about 5 feet, but where till has more clay, it is leached only 3 feet. 


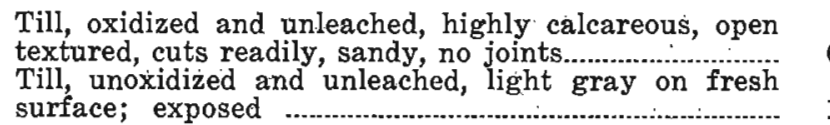

Oxidation has advanced along the joints in the unoxidized part and here the color is chocolate brown. The cut lies on level land and hence there probably has been no erosion. It is about 100 yards long and has a greater depth than is usually found in the Iowan.

Another section that shows unoxidized Iowan as well as an unusual thickness of this drift sheat was found in a gravel pit about 2 miles southwest of the Iowa State Teachers College at Cedar Falls, in the NE1/4 sec. 27, Cedar Falls Township, (T. 89 N., R. 14 W.), Black Hawk County. The section is :

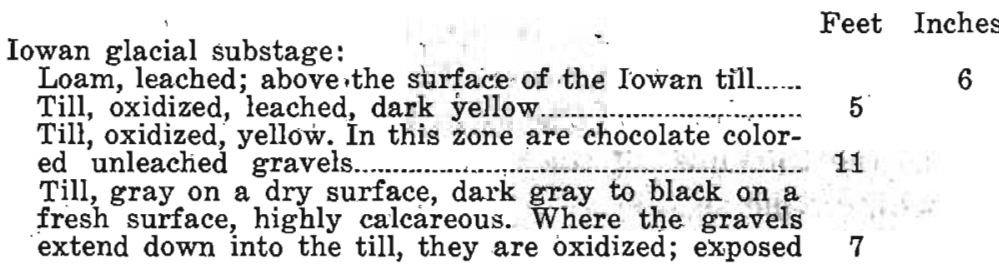

On the surface are some large boulders, one of granite, 6 by 8 by 10 feet. Just where the section was taken a boulder more than 3 feet in diameter lay on the surface of the Iowan with less than 6 inches of loam above. Also several large boulders were lying on the floor of the pit. The maximum thickness of loess-like clay at this pit is 3 feet. In places a faint pebble band may be seen at the top of the Iowan. The gravels show how much oxidized such materials can be while they are still calcareous, and the lower part illustrates very well the blackness of unaltered Iowan. Where the till is gravelly the depth of leaching is greater than where gravel is absent. Leaching must be about at a maximum here as erosion has been very slight.

Sections near the Mankato margin of this eastern area of the Iowan are interesting as showing the uniformity of conditions under which weathering of the glacial and interglacial materials took place.' The following road cut is typical. It was made through a low knoll in gently undulating Iowan topography that is mantled with thin loess, and it is located between secs. 35 and 36, Etna Township, (T. 89 N., R. 19 W.), Hardin County. It showed: 
Loess, oxidized, yellowish brown, leached.

2

Iowan glacial substage:

Till, oxidized, brown to brownish yellow, similar in color to the loess; pebbly, fairly compact, leached.....

Till, oxidized, yellow, lighter colored than the leached loess; unleached, concretions; exposed

The formation of a soil zone, the leaching of the loess and the weathering of the till, as revealed in this section, are identical with those processes as shown in the eastern counties of the Iowan plain. Similar features are to be seen in Grundy County, and a road cut east of Manly, in the $\mathrm{NW}^{1 / 4} \mathrm{NE}^{1 / 4}$ sec. 30, Union Township, (T. 98 N., R. 19 W.), Worth County, showed 7 feet of leached sandy Iowan till overlying Kansan gumbotil that was exposed for a thickness of $4 \frac{1}{2}$ feet.

The general uniformity of leaching of Iowan drift and loess is quite strikins. The usual thickness of the leached material is about $5 \frac{1}{2}$ feet in depth. A series of 'sections to show this are given below. Two sections near Cleves in Hardin County are interesting because the thickness of the loess is just about the critical depth of leaching. One section at the center of the north line of sec. 2, Clay Township, (T. 88 N., R. 19 W.), shows the following:

Peorian intraglacial substage:

Feet Inches

Loam, dark

Loess, brown to chocolate colored, mealy, leached........

Loess, oxidized, unleached, concretions.

3

Iowan glacial substage:

Till, yellow, pebbly, unleached; exposed along slope 4

Kansan glacial stage:

Gumbotil; plowed by Iowan ice; exposed

The next section, which is a mile south, on the west side of the road just north of the south boundary of sec. 2 , shows slightly different conditions:

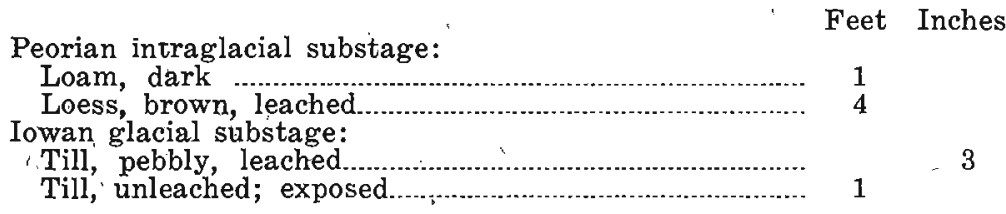

A large Iowan boulder lies,in the field east of the road.

A section in the tongue of Kansan plain that remains between the Iowan and the Mankato drifts shows the similarity of leaching where the loess overlies old drift. It is located in the $\mathrm{SE}_{1 / 4} \mathrm{SW}^{1 / 4}$ sec. 11, Eldora Township, (T. 87 N., R. 19 W.), Hardin County, and showed : 
Peorian intraglacial substage:

Loess, leached

Loess, unleached; exposed

Feet Inches

Again, in the northwest corner of sec. 8, Palermo Township, (T. 87 N., R. 17 W.), Grundy County, loess is leached to a depth. of $5 \frac{1}{2}$ feet, right down to the Iowan till, which is entirely unleached.

A gravel pit in the SW1/4. sec. 6, Palermo Township, (T. 87 N., R. 16 W.), Grundy County, just at the northeast edge of Grundy Center, shows leaching as follows:

Peorian intraglacial substage:

Feet Inches

Loess, leached, sandy

46

Iowan glacial substage:

Gravel, leached, fine...................................................

Another pit, this one in the northwest corner of sec. 29, Union Township, (T. 98 N., R. 19 W.), Worth County, shows 4 to 6 feet of loess over the gravels. The loess is all leached, but the gravels are unleached to the base of the loess and are, therefore, Iowan in age. They contain a very large proportion of limestone pebbles. The deposit seems to be an Iowan kame on the Iowan upland.

A road cut on a hilltop in the $\mathrm{NE}^{1 / 4}$ sec. 12, Polk Township, ( $\mathrm{T}$. 86 N., R. 9 W.), Benton County, shows no loess but only Iowan till, and this is leached for 5 feet. The upper 2 feet is black with humus but is pebbly to the top. A few secondary lime concretions are present in the upper part.

A pit in the upland $31 / 2$ miles north of Independence, in the NE1/4. sec. 15, Washington Township, (T. 89 N., R. 9 W.), Buchanan County, shows 1 foot of loam; black above and brown below, then a definite pebble band, succeeded by brown gravels that are leached to a depth of $5 \frac{1}{2}$ feet below the surface. Below this the gravels are oxidized but calcareous.

A fine road cut through a small knoll in the NW1/4 sec. 20 , Paris Township, (T. 98 N., R. 12 W.), Howard County, gave the following succession:

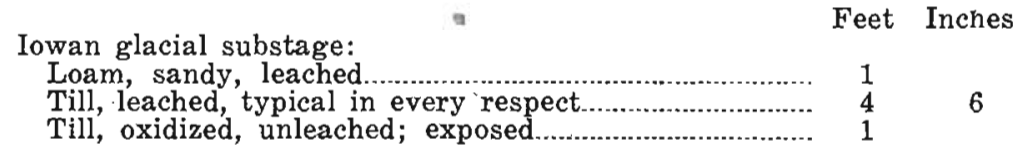

Another part of the cut showed only $4 \frac{1}{2}$ feet of leached I Iowan till, although there is no evidence of erosion. The unleached till 
is lighter colored than the leached. No loess is present on this knoll; in fact, loess is very.thin or absent over most of Howard County.

A section one-fourth of a mile south of Coggan, in the $\mathrm{NE}^{1 / 4} \mathrm{sec}$. 10, Jackson Township, (T. 86. N., R. 6 W.), Linn County, shows an unusual thickness of Iowan till, together with an unusual thinness of leaching.

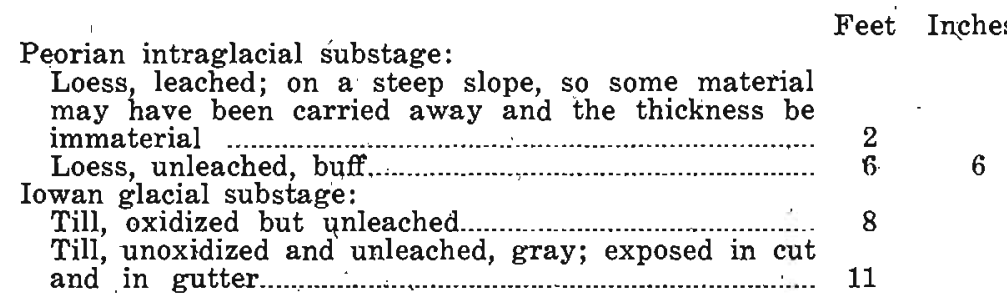

In . one place the cut gives evidence of plowing of an old clay soil by Iowan ice. .

Another good section of Iowan till and loess in a different part of Linn County is shown in the $\mathrm{SW}^{1 / 4} \mathrm{sec}$. 30, Clinton Township, (T. 83 N., R. 8 W.). This cut is surrounded by gently rolling, typical Iowan topography which seems to show no evidence of erosion since Iowan time. Hence, conditions would be especially favorable for maximum weathering.

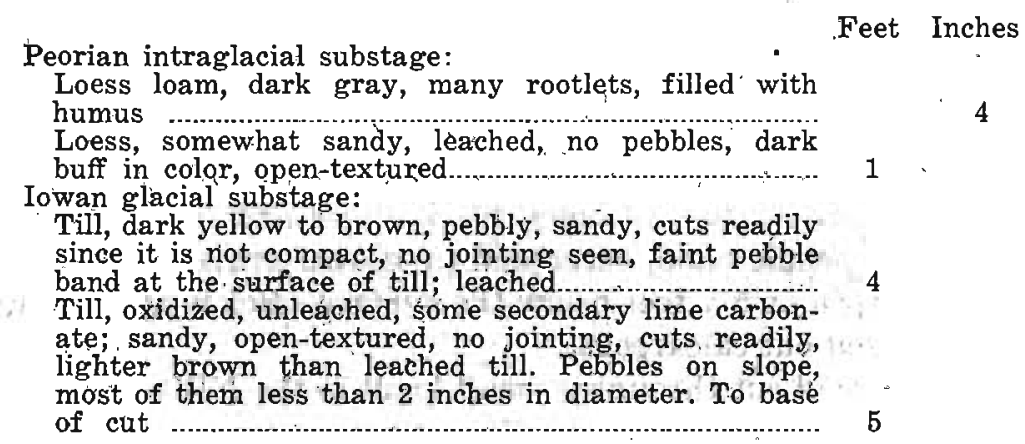

In this case the loess is not sharply differentiated from the till and looks as if it were closely related in age to the till.

Another section, this ore entirely in Iowan till with no overlying loess, was found in the $\mathrm{NW}^{1 / 4}$ sec. 5, Douglas Township, ( $\mathrm{T}$. 98 N., R. 15 W.), Mitchell County. It also illustrates very well the uniformity of leaching over this area, no matter what the material. It presents : 
Iowan glacial substage:

Feet Inches

Loam, black, sandy; exposed......................................... leached

Till, Jowan, oxidized, unleached, brown with gray spots, secondary lime to top of zone. Transition zone

'two' abrupt, within an inch or so. Exposed...................

\author{
1
}

36

2

\title{
Iowan-Drift in Northwestern lowa
}

The Iowan drift region that lies west of the Des Moines valley lobe of the late Wisconsin drift has the form of a long, narrow, irregular band whose eastern margin is defined by the western edge of the late Wisconsin plain and whose western margin was determined by the limits of advance of the Iowan ice itself. In,defining its limits Carman ${ }^{71}$ stated that it

“. . is an elongate area extending from Watertown, South Daktoa, across southwestern Minnesota and northwestern Iowa to the south boundary of Sac county, a distance of more than 200 miles. Through Minnesota its width is 10 to 20 miles. South of the state line the belt widens, because of the eastward swing of the Wisconsin boundary, to 40 miles in O'Brien and Clay counties. It narrows again to 15 miles in northern Cherokee and Buena Vista counties and terminates at the south line of Sac county.

"It includes most of that questionable area of northwestern Iowa which has been variously interpreted as covered with Wisconsin, extra-morainic Wisconsin, Early Wisconsin, Iowan, or Kansan drift."

Carman studied the region during several field seasons and finally correlated it with the Iowan of northeastern Iowa because its topography is less maturely erosional than is that of the Kansan plain to the west of it and at the same time is not so youthfully constructional as the Mankato plain on the east.

Carman $^{72}$ states, in describing the Iowan drift of northwestern Iowa that

"It is strongly calcareous, even to the surface, there being no leached zone."

This is true, and it doubtless is due to the fact that over most of its area the Iowan drift has a loess cover thick enough to protect it from leaching, either wholly or in greater part. This condition is much more prevalent in the western area than in the eastern Iowan region, and in turn it is probably due to the fact that while the Iowan loess of eastern Iowa was derived from the Iowan till itself, and therefore was blown off the Iowan drift plain, most of the loess of western Iowa was blown on to the Iowan drift, chiefly from the Missouri River flats.

\footnotetext{
TCarman, J. E., Further studies, on the Pleistoctue geology of northwestern Iowa: Iowa Geol. Survey, vol." 35, p. 39 , 1.981.

${ }^{72}$ Carman, J. E., op. cit., p. 48.
} 
However, a few sections have been found in which the upper part of the drift was leached, and in each of these instances the evidence was clear that the leaching of the till was possible because of the thinness of the loess. In other words, the same close relation exists here as in eastern Iowa between the thickness of the loess and the leaching or non-leaching of the materials below a certain fairly uniform depth. The depth of leaching is controlled by the character of materials to only a minor extent.

The glacial drift of western Iowa is much thicker than that of the eastern part of the state. In fact in many of the western counties the bedrock is buried beneath 200 to 400 or more feet of glacial materials, and in several counties rock outcrops are entirely absent. Because of this situation very few exposures in northwestern Iowa show contacts of drift and bedrock, and none are recorded in which Iowan drift lies on the indurated rock. No Iowan till has been recognized as lying on Nebraskan or Aftonian material and in only a few localities was till of Iowan age seen in contact with Kansan drift or any post-Kansan-pre-Iowan deposits.

One of the most inclusive and significant exposures of Pleistocene materials in western Iowa, or indeed anywhere in the state, is found in a series of road cuts along State highway no. 5 where it trenches the eastern valley wall of Little Sioux River east of Cherokee. These road cuts display materials ranging in age from Nebraskan till to Peorian loess. The series includes seven cuts between valley floor and upland, and the last two show Kansan till, yellow, oxidized and unleached, and overlain by $2 \frac{1}{2}$ feet of Iowan till, sandy, gravelly, oxidized, highly calcareous and with many limestone pebbles. Along part of the exposure a pebble band marks the top of the Iowan till, while elsewhere a narrow drab silt zone demarks the Iowan from the Kansan. Three feet of concretionbearing loess overlies the Iowan till at the upland level.

A composite section along this slope is about as follows:

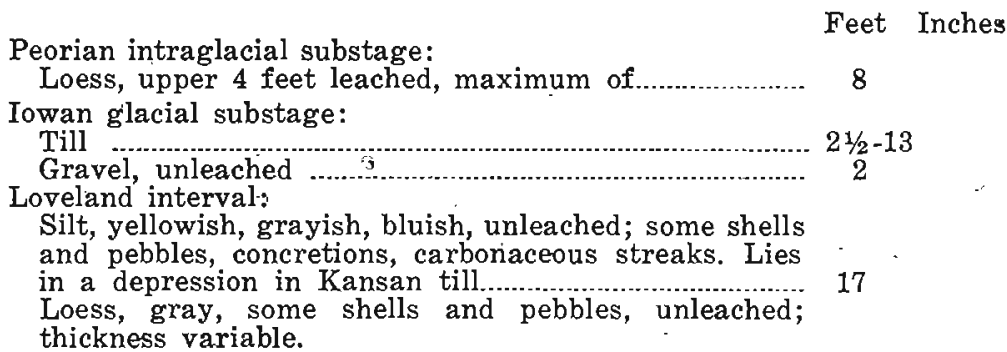




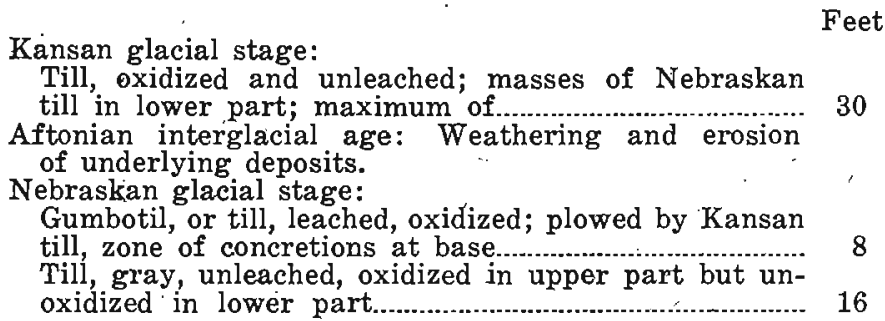

Another instructive series of beds is seen near the southeast corner of sec. 13, Liberty Township, (T. 93 N., R. 41 W:), in the same county. Here at the bridge crossing of Mill Creek is exposed oxidized and unleached Kansan till rising above water level. Above the bridge are Loveland silts, which are drab to brownish, fossiliferous and unleached. The thickness of the silts is 25 feet, and here the silts are overlain by 6 feet of fresh light-colored gravel and this in turn by a few feet of loess. The gravel and overlying loess are evidently. Iowan and Peorian respectively.

About 100 yards north of the corner, along the road between secs. 13, Liberty Township, (T.' 93 N., R. 41 W.), and 18, Cedar Township, (T. 93 N., R. 40 W.), a road cut shows above road level 11 feet of fossiliferous loess, of which the lowest 3 feet is bluish while the upper part is gray. Above this loess, which is Loveland in age, lie 4 to 5 feet of fresh Iowan gravels and above them is Peorian loess, brown in color and leached for $51 / 2$ feet below the surface. The lower 2 inches of loess is unleached, and the underlying gravels are also unleached.

A mile south and half a mile east of this corner, where the road through the middle of sec. 19, Cedar Township, (T: 93 N., R. 40 W.), crosses Mill Creek, is another significant section. Piecing together the elements of the different exposures we get the following:

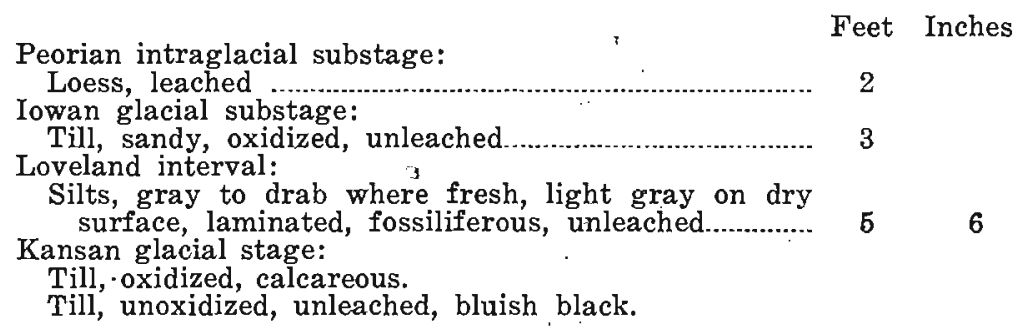

A somewhat different series of materials is exposed in a group of stream cuts southeast of Cherokee, in Pilot Township, (T. 91 N., 
R. $40 \mathrm{~W}$.). In the southwest corner of sec: 1; the creek has cut into its south bank and exposed:

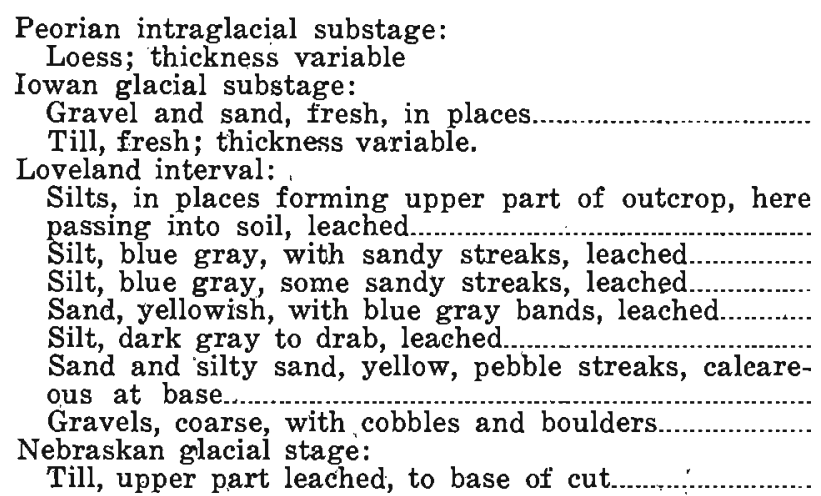

Feet Inches

$\begin{array}{ll}3 & \\ 2 & \\ 3 & \\ 2 & \\ 2 & 6 \\ 1 & 6 \\ 5 & \end{array}$

Within sight of this exposure, about 200 yards down stream, across the highway and the railroad, in the southeast comer of sec. 2; the creek has cut.into its west bank and exposed a comparable section.

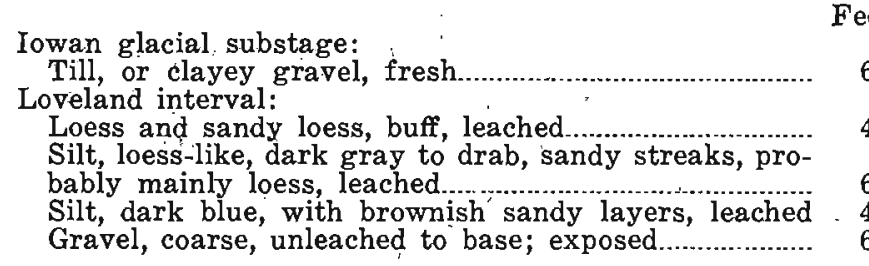

Feet Inches

Kansan till may be seen close by at the lower level of this cut.

About one-half mile south of these cuts, in a ravine in the $\mathrm{SE} 1 / 4$ $\mathrm{NE} 1 / 4$ sec. 11, may be seen a fine section showing Loveland materials lying in a depression in Nebraskan till. It is as follows:

Loveland interval:

Feet Inches

Clay, buff to brownish, loess-like, with a few thin

seams of sandy material, leached.

Silts, sandy and gravelly, calcareous.

Gravel and sand, mottled dark brown, some $\mathrm{MnO}_{2}$

calcareous ...................... Thick-

6

ness variable:

Silt, dark gray, sandy, calcareous, some carbona-

ceous material.................................................................. 2

Nebraskan till rises about 8 feet above the base of the exposure on the south side and may be seen also on the opposite side, show- 
ing the presence of a depression in the till. In one place a few feet of oxidized Kansan till intervenes between the Nebraskan and the Loveland. Here the silts are leached for 7 feet. On the surface an Iowan boulder was observed. Horizontal laminae are plainly, to be seen in the silts.

Leaching of the Iowan materials seems to have differed considerably in depth, although most probably these differences are not greatly significant, showing chiefly effects of location, erosion-or other local factors. Two road cuts near to each other in Pitcher Township, (T. 91 N., R. 39 W.), Cherokee County show rather marked variaton in this regard. One of these is in the NW $1 / 4$ sec. 24 and shows:

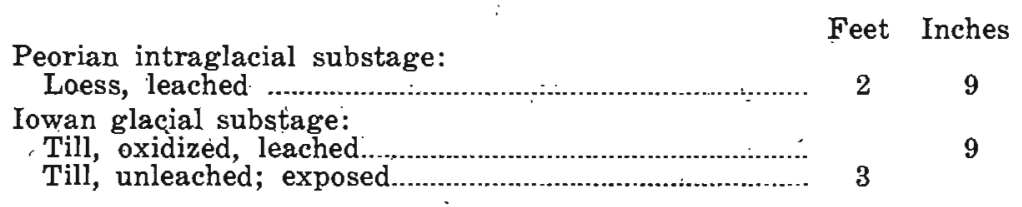

The other is a mile south, in a gently rolling region in the NW $1 / 4$ sec. 25. It revealed:

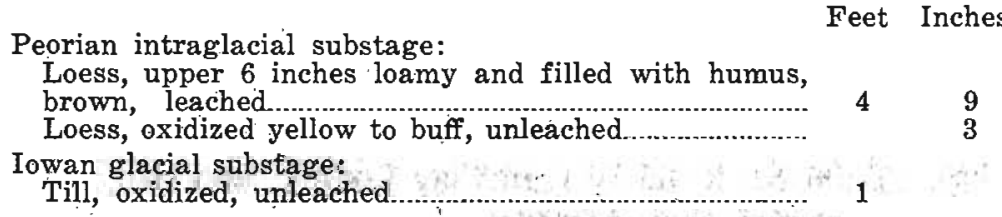

Another road cut, this one in the SE $1 / 4$ sec. 28, Afton Township, (T. 92 N., R. 39 W.), not far from a tributary of Little Sioux River, showed:

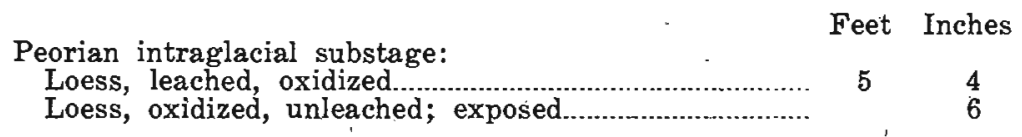

A similar depth of leaching in loess was observed on the east line of the SE $1 / 4$ sec. 26, Pilot Township, (T. 91 N., R. 40 W.), on fairly level upland.

Exposures in other counties of the Iowan area show a similar range in depth of leaching. For instance, near Early, in Sac County, the following sections are illustrative. A gravel pit near the southwest corner of sec. 10, Boyer Valley Township, (T. $88 \mathrm{~N}$, R. 36 W.), shows: 
Peorian intraglacial substage:

Feet Inches

Loess, brown, oxidized, leached

Gravel, oxidized; leached.

Gravel, unleached; exposed

These are Iowan upland gravels. Some large boulders are present.

On the south side of the $\mathrm{SE} 1 / 4$ sec. 3 of this township a road cut showed:

Peorian intraglacial substage:

Feet Inches Loess, brown, leached.

Iowan glacial substage:

Till, brown, sandy, pebbles, some of limestone, 5 leached; exposed

This cut is on the flat Iowan upland, about a mile west of the Mankato drift boundary.

Nearly 4 miles west, on the south side of the SW1/4 sec. 6 , Boyer Valley Township, (T. 88 N., R 37 W.), another road cut on the level upland showed:

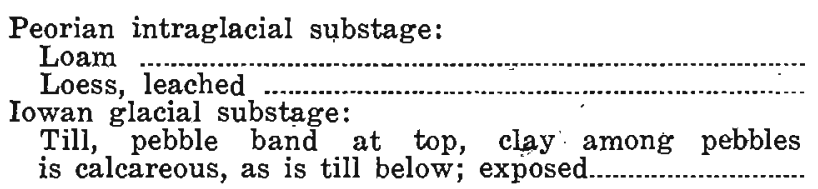

owan glacial substage:

is calcareous, as is till below; exposed.........................

Feet Inches

Just southeast of Dickens in the NW1/4 sec. 20, Freeman Township, (T. 96 N., R. 35 W.), in Clay County, and still in the Iowan area, is a section that showed:

Peorian intraglacial substage:

Feet, Inches

Soil, dark, humus filled.

Loess, brown, leached

Iowan glacial substage:

Till, oxidized, leached.

Till, unleached, exposed

$\begin{array}{ll}3 & 6 \\ 2 & 6\end{array}$

This section shows an intermediate depth of leaching. The minimum amount is found in a road cut between secs. 4 and 9, Carroll Township, (T. 96 N., R. 42 W.), O'Brien County. It showed:

Peorian intraglacial substage:

Feet Inches Loess

Iowan glacial substage:

Till, highly calcareous.

$1-3$

Loveland interval:

Loess or silt, gray, plowed, highly calcareous.............
Loess, dark gray or buff, calcareous, then $11 / 2$ feet of $2-3$

Loess, dark gray or buff, calcareous, then $11 / 2$ feet of
light buff, leached, then $11 / 2$ feet, light buff, slightly calcareous. No till exposed below. 
An excellent section at the railroad crossing on the east line of sec. 12, Union Township, (T. 94 N., R. 41 W.), O'Brien County, showed:

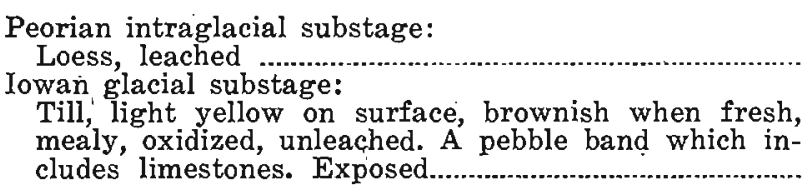

Feet Inches 5

Another interesting exposure illustrating leaching is in a gravel pit in the southwest corner of sec. 8, Liberty Township, (T. 94 N., R. 40 W.), of this same county. It showed:

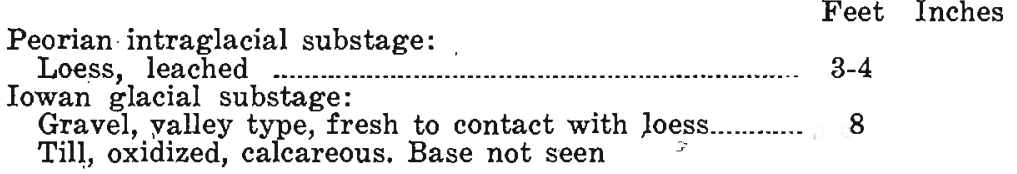

Several other sections in loess near Paullina in O'Brien County show about 4 feet of leaching, as on the west line of the NW1/4 sec. 15, Union Township, (T. 94 N., R. 41 W.), where 4 feet of leached loess overlies a pebble band on fresh Iowan; in the $\mathrm{SW} 1 / 4$ sec. 10 , Union Township, (T. 94 N., R. 41 W.), and in the NE1/4 sec. 9, Liberty Township; (T. 94 N., R. 40 W.), where on level land, 3 feet 10 inches of loess was exposed over unleached loess; also in the Kansan area, on the south line of the SE $1 / 4$ sec. 1, Caledonia Township, (T. 94 N., R. 42 W.), which showed 4 feet 4 inches of leached loess, below which was exposed a foot of unleached loess. On the opposite side of the road, however, loess and till together were leached only 2 feet 7 inches, 1 foot of this being till.

Two sections in East Holman Township, (T. 99 N., R. 41 W.), Osceola County, are interesting as giving a contrast in the amount of leaching in the Iowan and Mankato areas. One of these road cuts, on the south line of the $\mathrm{SE}^{1 / 4}$ sec. 11 , about a mile within the margin of the Mankato drift plain, showed:

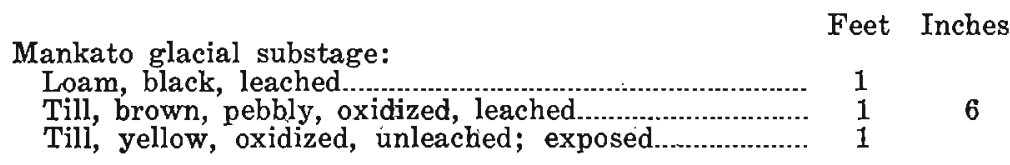

In contrast, another cut 4 miles to the west, on the south line of the SE1/4 sec. 7, (T. 99 N., R. 41 W.), and on the Iowan plain, presented: 
Peorian intraglacial substage:

Feet Inches

Loam, black to brown

Loess, lighter brown to yellow, leached.

1

Iowan glacial substage:

Till, yellow, oxidized, many limestone pebbles. Clay

leached for a few inches, but limestones fresh; exposed

3

1

No loess is present in the first cut, and leaching has progressed only $2 \frac{1}{2}$ feet. In the lowan area, several feet of loess overlies the till, and leaching has advanced 4 feet, which is also about the depth of leaching in loess over the Kansan drift.

Gravel pits have been operated at Sibley for many years, and thorough studies have been made of the deposits, especially by Carman. ${ }^{73}$ In general these pits show 3 to 4 feet of loess, all leached down to the gravels, which, however, are fresh to their contact with the loess. Inclosed within these gravels are masses of yellow unleached Iowan till.

Similar conditions as to thickness and leaching of loess and underlying materials prevail to the western margin of the Iowan area. Road cuts and other exposures within the Iowan region are in general so shallow that little or no idea of the thickness of the Iowan drift can be obtained. One or two sections will explain conditions on both sides of the margin. In the southwest corner of sec. 12, Grant Township, (T. 99 N., R. 43 W.), Lyon County, a road section in the upland Iowan plain revealed:

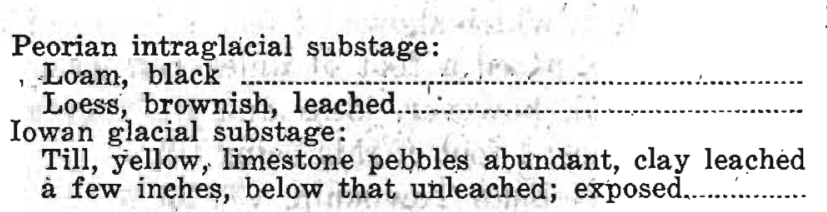

Feet Inches

This exhibits about the average amount of leaching for this region. Farther west, in the Kansan region, a road cut in the middle of the south line of sec. 32, Midland Township, (T. 100 N., R. 44 W.), Lyon County, showed about the minimum leaching found outside the Mankato plain, namely $3 \frac{1}{2}$ feet, while another section just south of Rock Rapids, on the east line of the $\mathrm{SE} \cdot 1 / 4 \mathrm{sec}$. 8, Rock Township, (T. 99 N., R. 45 W.), revealed a depth of leaching, 41/2 feet; that seems to be about normal. The unleached yellow loess is here about a foot thick over the till.

As one travels westward from the Mankato margin over the

\footnotetext{
${ }^{73}$ Carman, J. E.. The Pleistocene geology of northwestern Iowa: Iowa Geol. Survey, vol. 26, pp. 886-391, 1917 .
} 
Iowan plain and then over the Kansan region, a noteworthy thickening of the loess is observable, but the amount of leaching in this loess-or where it is thin enough to be leached to its base, in the underlying till or graviel-is fairly uniform within a certain range of variation. One gets the impression that the average of leaching in this northwestern region of Iowa is nearer 4 or $4 \frac{1}{2}$ feet than the $51 / 2$ feet that is so common in eastern Iowa.

\section{Descriptions of the Drift Phases}

\section{Iowan Boulders}

One of the most striking characteristics of the Iowan drift and its topography is the great number of boulders that are displayed. All of the drifts are boulder-bearing, but the Iowan ice, for some reason, seems to have brought down more large boulders than any of the other ice sheets.

A noteworthy feature of these boulders is the fact that most of them are of the lighter colored granitic types rather than the darker ferro-magnesian kinds which form so large a percentage of the boulders of the Kansan and Nebraskan till sheets. Alden and Leighton ${ }^{74}$ mapped the locations of large granitic boulders in Iowa and the relationships of these boulders to the northeastern area of Iowan drift are shown in figure 30.

Another factor that aids in making the Iowan boulders conspicuous is the thinness or absence of the loess over the Iowan plain. Doubtless, many boulders are buried in the loess of southern Iowa, but this is not possible, at least not to the same extent, in the Iowan area, for both the loess and the drift are thinner here.

Boulders are common sights in the landscape of nearly all parts of the Iowan, but they are noted especially in the eastern counties, where some of great size were present in earlier days. Many of these have been broken up and removed but a goodly number of large ones still form notable landmarks.

Calvin, ${ }^{75}$ in describing the Iowan drift of Howard County, used , these words, that are very inclusive, in describing these rocks:

"The bowlders are coarse-grained" and light eolored, and it is a surprising fact that in all northeastern Iowa approximately three-fourths of the entire bulk of the Iowan erratics represent but one type of granite which might all have come from a single locality. Iowan boulders are large and numerous as compared with bowlders in the Kansan drift, but the variety and number of rock species are far greater in the Kansan than in the lowan."

\footnotetext{
"Alden, W. C., and Leighton, M. M., The Iowan drift, a' review of the evidences of the. Iowan stage of glaciation: Iowa Geol. Survey, vol. 2b, p. 122, 1917.

TCalvin, Samuel, Geology of Howard County: Iowa Geol.' Survey, vol. 18, p. 68, 1903.
} 


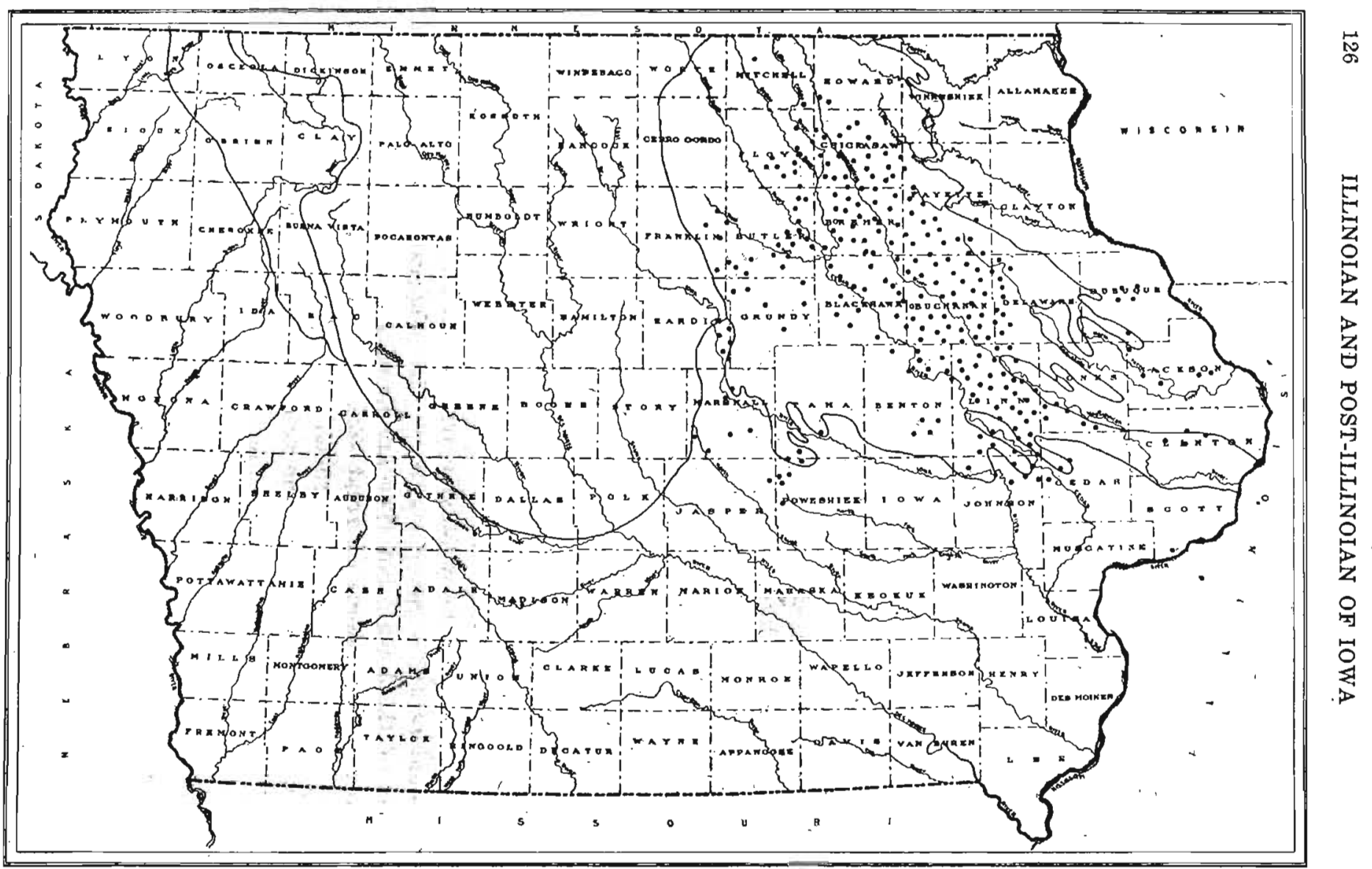

Figure 30. Map of lowa showing the locations of large granitic boulders in and adjacent
to the Iowan drift, area. (Modified from Alden and Leighton, 1917.) 
Calvin pictures a boulder of this type in sec. 22, Jamestown Township, (T. 99 N., R. 14 W.), Howard County, that is 20 by 12 by 9 feet in dimensions, and Williams ${ }^{76}$ describes one in Worth County, north part of sec. 14, Kensett Township, (T. 99 N., R 20 W.), that is 20 by 12 feet in horizontal dimensions and rises 12 feet above the ground.

In the SW $1 / 4$ sec. 18, Dresden Township, (T. 94 N., R. 12 W.), Chickasaw County, many and large boulders were noted, also for several miles south, somewhat as if they might have been left in a boulder train by the ice, (fig. 31 ). They are especially numerous and large in the swales, although they also lie well up on the slopes.

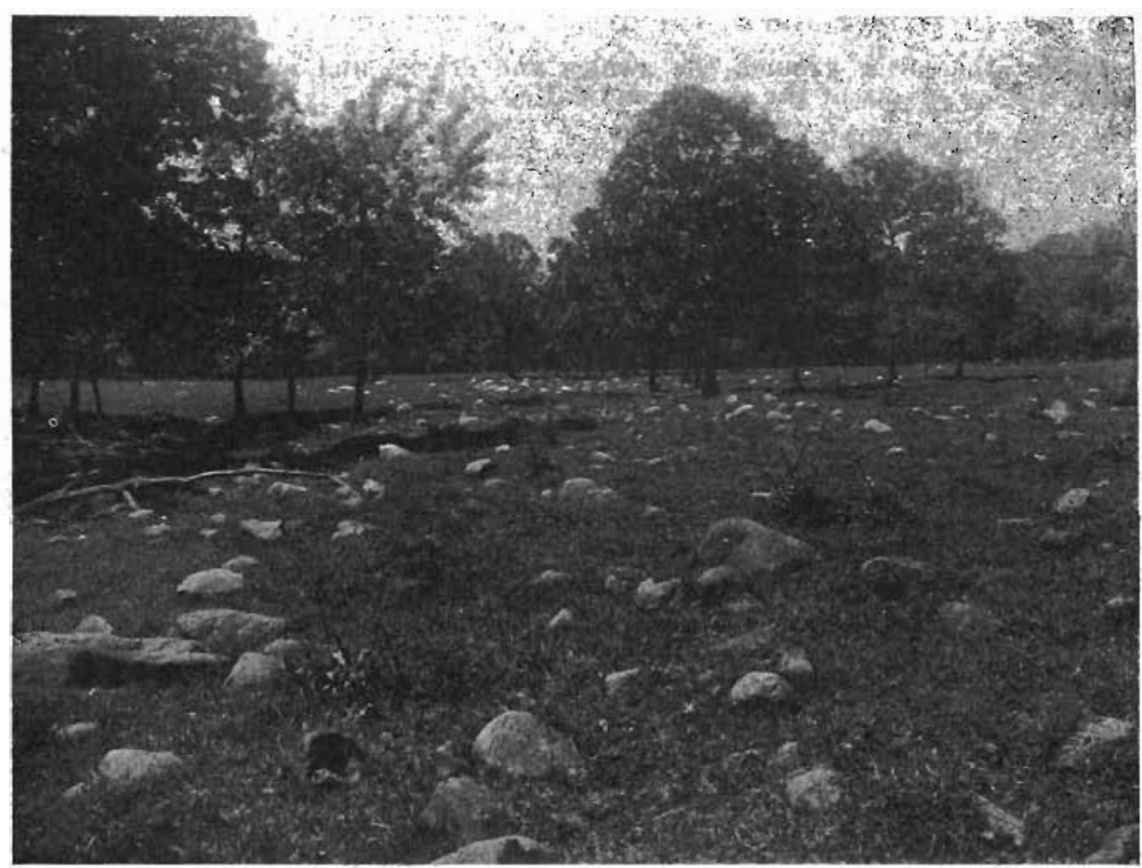

Figure 31. Field of Iowan boulders south of Bassett, Chickasaw County.

In one field of a few acres extent 21 large ones were counted, many of them more than 10 feet in smaller diameters. The largest boulder in this county, and perhaps the largest in the state, is known as St. Peter. It lies in the SW1/4 sec. 3, Washington Township. (T. 97 N., R. 13 W.), and is fully 20 feet high and over 80 feet in circumference (fig. 33).

\footnotetext{
78Williams, I. A., Geology of Worth County: Iowa Geol. Survey, vol. 10, p. 362, 1900 .
} 
Savage, ${ }^{77}$ in his description of the geology of Fayette County, states that these

"large granite masses are conspicuous in the townships of Jefferson, Oran, Freemont, Banks, and Bethel. Near the eastern border of the Iowan drift plain the boulders are even more abundant, but they are usually much smaller in size."

They have also been noted between Fayette and Maynard and from West Union to New Hampton.

Norton, ${ }^{78}$ in the course of a thorough discussion of the Iowan boulders of Bremer County, mentions the excess of granites over darker types; the freshness of most of the boulders, also their faceted and scored surfaces, showing that they were carried at the base of the ice and of the drift; the fact they

"affect the lower ground, the swales and draws, and are less often seen upon the low crests of the gently undulating plain."

$\mathrm{He}$ also states that

"The boulders of Bremer county, while by no means rare, do not seem by any means as plentiful as those of the areas nearer the eastern margin of the Iowan drift."

He shows views of several boulder groups, but states that they are exceptional. Some boulders mentioned are: one in sec. 1, Douglas Township, (T. 93 N., R. 13 W.), that is 20 by 12 by 8 feet, while another $1 \frac{1}{2}$ miles southeast of Frederika, is 22 by 15 by 4 feet above ground. He speaks of one $2 \frac{1}{2}$ miles north of Sumner that was described by McGee as being 25 by 40 feet in diameter and rising 11 feet above ground. Much had been quarried away and most of the rock appeared to be buried in the ground.

Butler County is another of those in which boulders are abundant, some large and relatively solitary, others small and thickly sprinkled on the fields. Arey ${ }^{79}$ says that

"In places boulders are surprisingly abundant while elsewhere they are wholly wanting or found only in the sags. Pilot Rock, in the west half of section 23, West Point township, has a girth of 99 feet and maximum height of $121 / 2$ feet."

Buchanan County is one of those most noted for the size and number of its erratics, (fig. 32). In early days these were abundant on every hand. Calvin ${ }^{80}$ stated that

"Boulders ten, fifteen or twenty feet in diameter, and standing conspicuously above the general surface, are common features of the prairie landscapes, and great granite masses, thirty feet in diameter, are known at several points. Multitudes of smaller boulders, ranging from three feet in diameter, are a serious encumbrance in many fields and pastures."

TrSavage, T. E., Geology of Fayette County: Iowa Geol. Survey, vol. 15, p. 528, 1905

TSNorton. W. H.. Geology of Bremer County: Lown Geol. Survey, vol. 16, pp. 372-375, 1906.

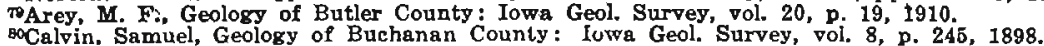




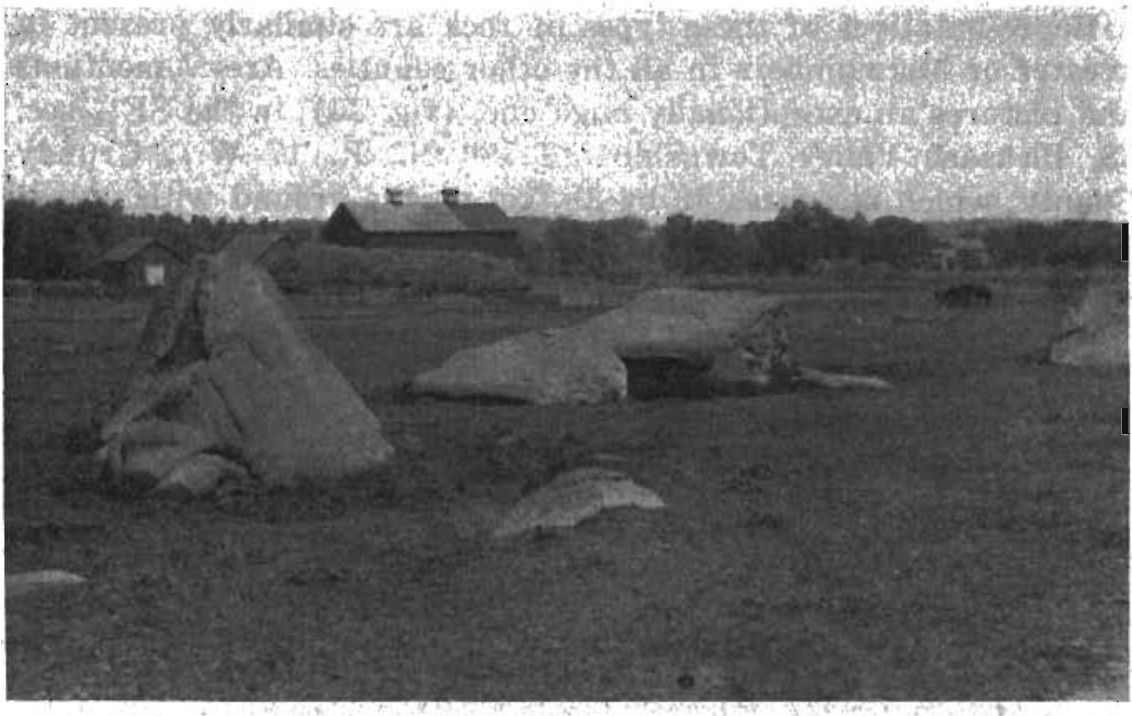

Figure 82. Large lowan boulders in Buchanan County.

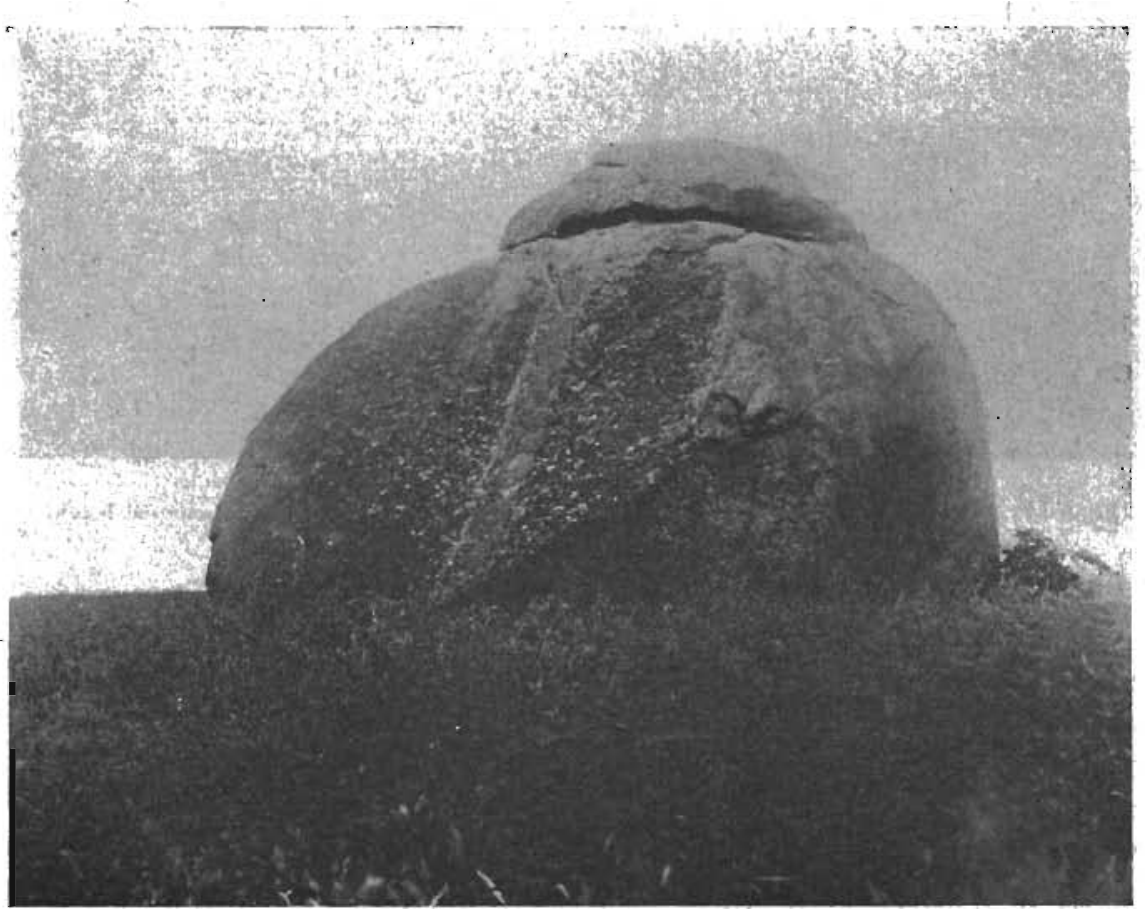

Figure 83. Large Iowan boulder in Chickásawi County. 
Representatives of these types of rock are similarly present in greater or less numbers in all the other counties. Arey ${ }^{81}$ mentions and pictures an exceptionally huge one, (fig. 34), in the $S E^{1 / 4}$ sec. 38, Pleasant Valley Township, (T. 89 N., R. 17 W.), Grundy County, which measures 32 by 28 feet on the ground with an exposed height of 10 feet. He also mentions another nearly as large and further states that

"The western part of Pleasant Valley township has an unusual number of large boulders, as do portions of Beaver and Fairfield townships."

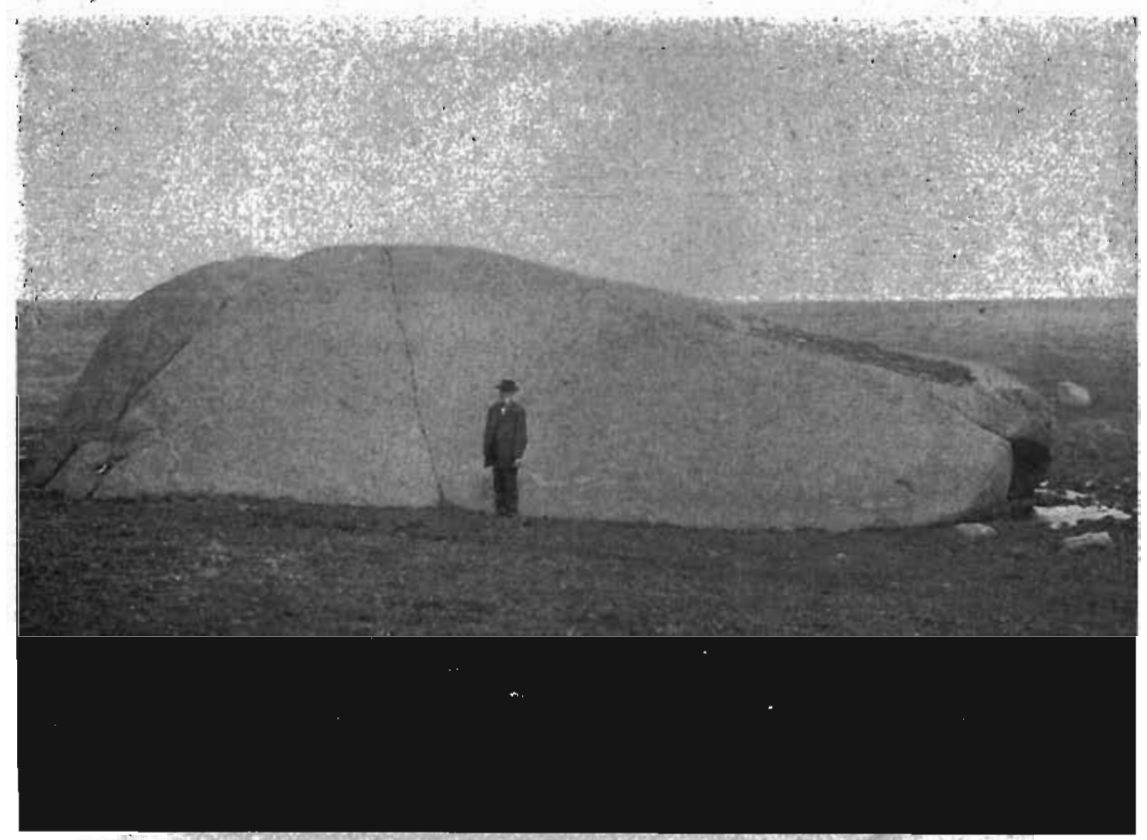

Figure 34. Towan boulder in Grundy County measuring 82 by 28 feet with an exposed height

The Iowan Pebble Band

The senior author, in 1931, published a paper $^{82}$ on the pebble band on Iowan till. In this paper it is stated that within the area of Iowan drift in northeastern Iowa, thin Peorian loess overlies in many places a distinct pebble band at the surface of the Iowan till. Where the pebble band is absent, the loess lies directly on the till. Where no loess is present on the till, the till in upland sections is leached to a depth of approximately 5 feet. Where loess

81 Arey. M. F., Geology of Grundy Gounty: Iowa Geol. Survey, vol. 20, p. 86, 1910

202Kay, G. F., Origin of the pebble band on Iowan till: Jour. Geology, vol. 39, pp. 377-380, 1931. 
is on the pebble band or on till and is of sufficient thickness to be unleached in its lower part, the underlying Iowan till is unleached to its surface. Where the loess is thin and leached, the upper part of the till is leached also, whether the pebble band is or is not present, the combined leaching of the loess and till being about the same in depth as where no loess overlies the till.

Thick Peorian loess which is apparently genetically related to the Iowan till is uniformly present beyond the borders of the Iowan drift where presumably good anchorage was afforded by the vegetation of the extra-marginal Kansan drift areas. This loess thins with distance from the Iowan; and, furthermore, the constituent parts of the loess are largest at the border of the Iowan and become smaller and smaller as distance increases from the border.

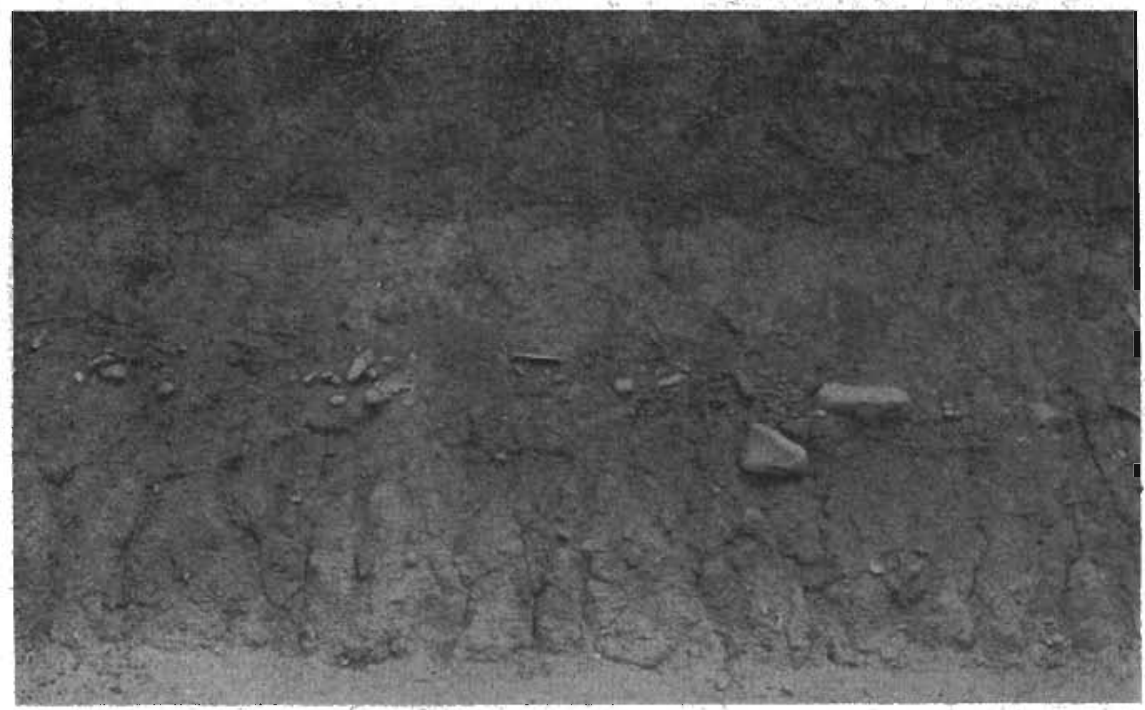

Figure 35. Pebble band with Iowan till below and Peorian loess above, Fremont Township,

One of the best exposures within the whole Iowan area showing the line of pebbles with Iowan till below and loess above was observed in a road cut in the middle of the line between secs. 1 and 2, Fremont Township, (T. 82 N., R. 3 W.), Cedar County (fig. 35). This cut is in an area of gentle topography. The section is as follows : 
Peorian intraglacial substage:

Loess, oxidized to brownish color, leached

Feet Inches Iowan glacial substage:

Pebble band, a thin row of pebbles.

Till, oxidized, grayish yellow to yellow color, no ferretto, sandy, contains sand pockets, jointed, upper 1 foot 3 inches leached, lower part unleached.

Here some of the fragments of rock in the pebble band show wind polish (fig. 36). But in many places the pebbles of the pebble bands lack evidence of wind action. Nor do the pebbles show surface effects due to water action; they are similar to the pebbles which are common in glacial till.

Another good section showing a pebble band is at Denver Junction, Jefferson Township, (T. 91 N., R. 13 W.), Bremer County, (fig. 37).

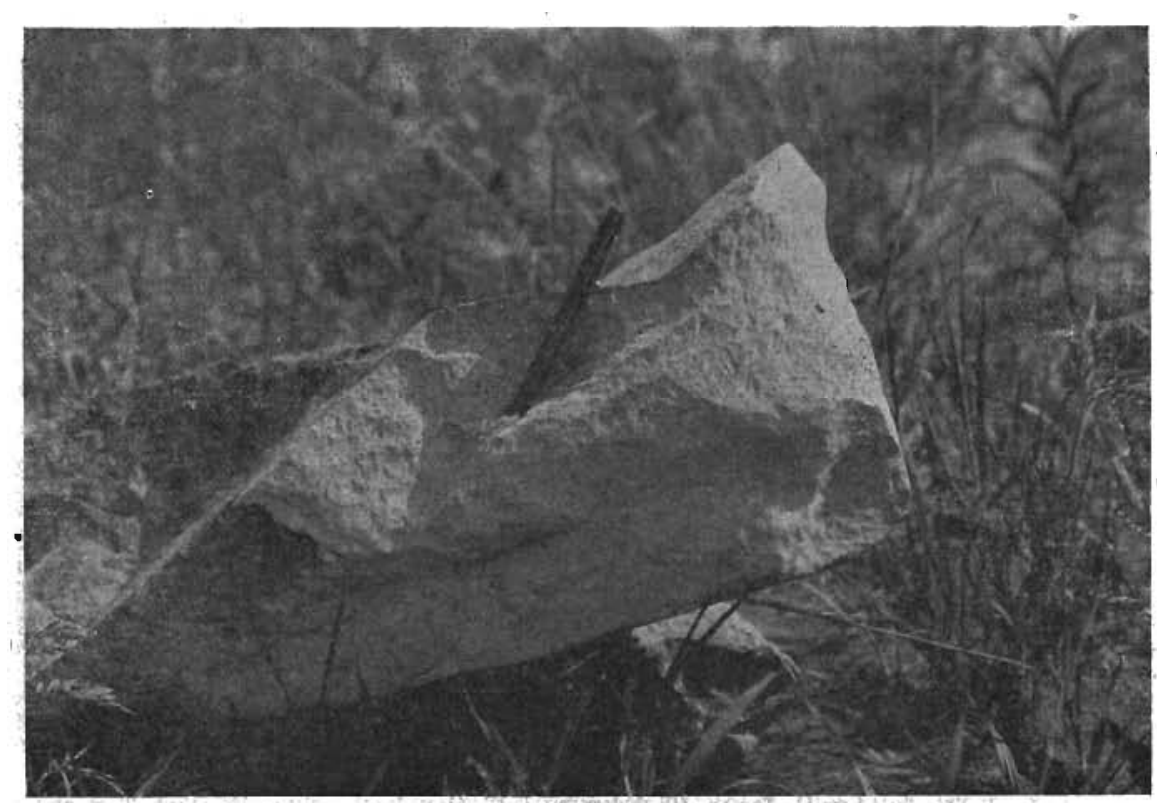

Figure 36. Wind polish on boulder from pebb'e band. Fremont Township, Cedar County.

A road cut near the center of sec. 32, Deer Creek Township, (T. 100 N., R. 19 W.), Worth County, shows the following section:

Peorian intraglacial substage: Loam or clay, loess-like.

Feet Inches

Iowan glacial substage:

Till, with striated cobblestones, a distinct pebble

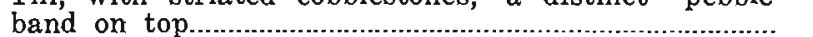

Kansan glacial stage:

Gumbotil, typical; exposed 
This cut was made through a swell on the drift plain; the Iowan till is very thin. The swell is a feature of a level stretch of country south of Northwood.

At the crossroads just east of Oelwein, (T. 91 N., R. 9 W.), Fayette County, is a good section showing:

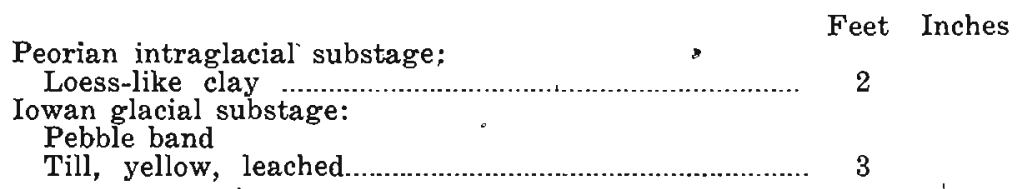

Another cut in the middle of sec. 22, Jefferson Township, (T. 91 N., R. 9 W.), of the same county shows a fine distinct pebble band that conforms to the slope of the land surface. It lies on the top of Iowan till and is overlain by loess-like clay. Some of the cobbles in the pebble band extend up into the clay.

A well developed pebble band is at the middle of the south half of the line between secs. 34 and 35 of Lincoln Township, (T. 87 N., R. 14 W.), in Black Hawk County. This section shows under 3

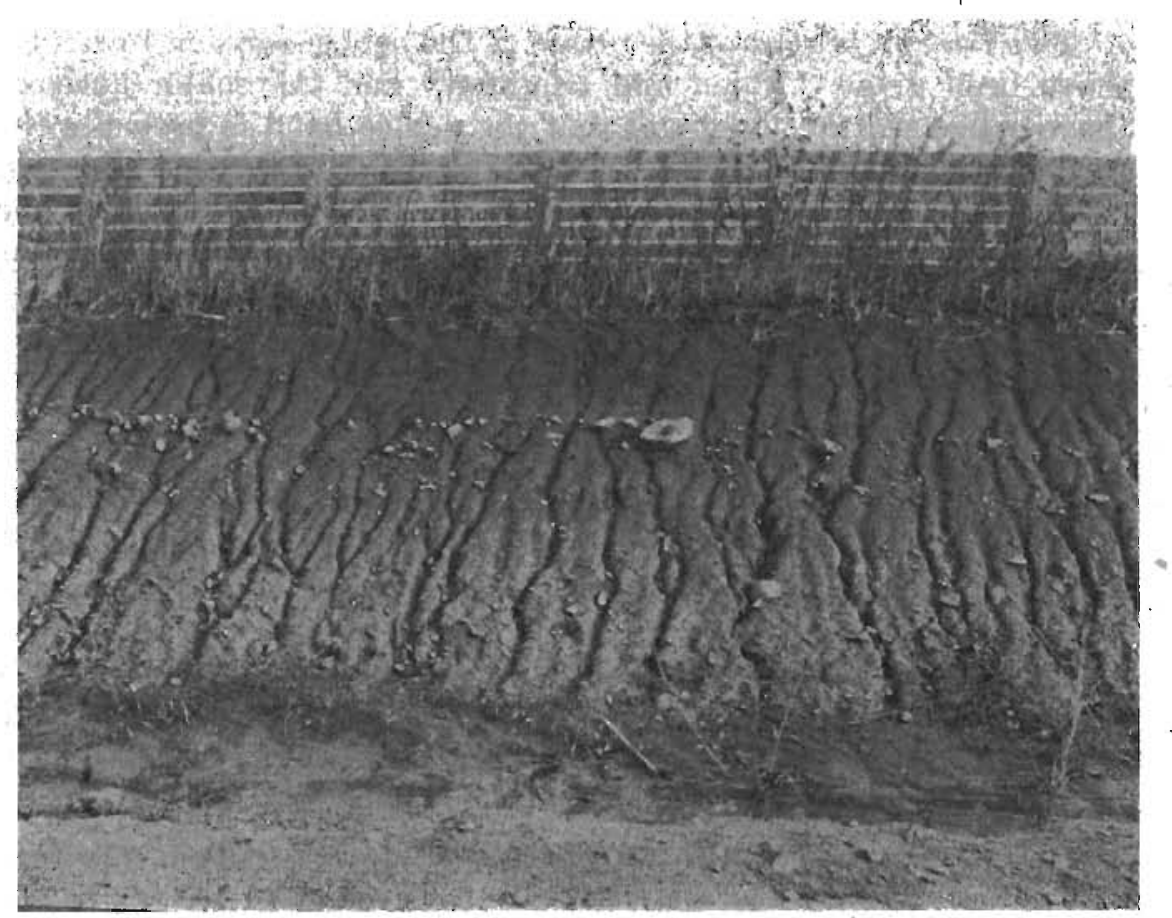

Figure 37. Pebble band on Iowan till just west of Denver Junction, Bremer County. 
feet of a loamy clay, a well developed pebble band. .Beneath this is Iowan till with a maximum thickness of 3 feet, and below this is Kansan gumbotil.

Near the middle of sec. 25, Clinton Township, (T. 83 N., R. 8 W.), Linn County, a cut shows Iowan' till forming a mound and having a pebble band at the top. The whole is covered by thin loess.

A pebble band occurs in a cut at the corners of secs. 28, 29, 32, 33, Massilon Township, (T. 82 N. R. 1 W.), Cedar County. This exposure shows 3 feet of leached loess lying on a distinct pebble band, on Iowan till. Some of the pebbles show evidence of wind polishing.

Pebble bands were observed also at the middle of the line between secs. 27 and 28, Cedar Township, (T. 97 N., R. 16 W.), Floyd County, at the top of gravelly Iowan till, with a little loam above; between Frederika and Waverly in Bremer County, where they were seen with striking frequency in the shallow roadside cuts; in several cuts between Fayette and Maynard, in Fayette County; and in many other cuttings into the Iowan plain.

Pebble bainds are also found in places on the Iowan till in northwestern Iowa.

Two interpretations of the origin of the pebble band on Iowan till have been given. Alden and Leighton ${ }^{83}$ and the senior author ${ }^{84}$ have expressed the judgment that the pebble band is probably the residual coarse material left from the slight wind erosion and rain wash which occurred in places before the till was protected by the loess. The evidence suggests strongly that the pebble band was formed and the overlying loess was deposited in a comparatively short time after the deposition of the Iowan till. In fact, the area within which the pebble band was developed was probably a marginal area free from vegetation in front of the retreating Iowan ice sheet. Winds blowing outward from the diminishing glacier picked up the fine material from the ground moraine and outwash areas from which the ice sheet had withdrawn, leaving a pebble band, which soon afterward was covered by loess which was being deposited and redeposited within the area of wind action.

The second interpretation of the origin of the pebble band has been-advanced by Leverett. ${ }^{85}$ He considers the pebble band to have been the result chiefly of the erosion of several feet of the Iowan till by running water, and that considerable time was involved in its

\footnotetext{
Alden, W. C., and Leighton, M. M., The Iowan drift, a review of the evidences of the Iowan stage of glaciation: Iowa Geol. Survey, vol, 26, pp. 83-156, 1917

akay, G. F., The relative ages of the Iowan and plinoian drift sheets: Am. Jour. Sci., vol. 16, pp. $506-508,1928$

boverett. Frank, The Pleistocene glacial stages: were there more than four? Am. Phil. Soc. Proc. vol. 65, p. $111,1926$.
} 
formation. He favors the view that the till on which the pebble band was formed was the result of an ice sheet from the Keewatin field and equivalent in age to a late phase of the lllinoian drift. $\mathrm{He}$ is of the opinion that the time between the deposition of the till within the Iowan area and the deposition of the overlying Peorian loess was comparable to the time between the deposition of the Illinoian drift and the deposition of the Peorian loess overlying the Illinoian drift. He would make the Iowan drift the product of a late phase of the Illinoian age of glaciation and would apply the name Sangamon to the interval between the time of deposition of the Iowan and that of the overlying Peorian loess as well as to the time of deposition of the Illinoian drift and that of the Peorian loess which overlies it. On this interpretation the pebble band was formed not by wind action but chiefly by slope wash during the long Sangamon interval.

An aid to the solution of the problem of the origin of the pebble band has been presented by Hobbs ${ }^{s 6}$ who has found similar phenomena in Greenland. He states :

"All the characteristic effects of the wind within the better-known desert areas of lower latitudes are here found reproduced on or about the outwash plains of the continental glacier of Greenland---there are the Armored floor (pebble bed), the loess deposits within a zone marginal to the glacier,-scattered boulders profoundly etched by sand-blast erosion--and all explained by the wind of the glacial anticyclone generated by the glacier itself and operating upon its own outwash deposit."

Later in his paper he states:

"The. Greenland ice sheet is surrounded by a rugged plateau deeply dissected and representing differences of level of several thousand feet; whereas the continental glaciers of North America lay over much flatter country. Within the middle Mississippi Valley the zone of outwash, instead of being restricted to the heads of fjord valleys, as it now is in Greenland, must have formed an almost continuous zone marginal to the ice sheet. Under such conditions one may picture a zone of loess marginal to the ice, deposited in places upon till, and exhibiting thin pebble beds and scattered boulders which are etched by the sand blast as these have been found in Iowa particularly. Deposits of till would also to some extent supply materials for wind transport. In Southeast Greenland, however, there is found but little till to be affected."

\section{Oxidized and Leached Iowan Till}

The uppermost phase of the Iowan till proper is oxidized and leached till, as no gumbotil has been formed on the till. The normal sequence of drift phases of the three older tills includes gumbotil, oxidized and leached till, oxidized and unleached till, and unoxidized and unleached till, in downward succession, the

\footnotetext{
${ }^{3}$ Hobbs, W. H., Loess pebble bands, and boulders from glacial outwash of the Greenland Continental glaciers: Jour. Geology, vol. 39 , pp. $381-385,1931$.
} 
gumbotil phase representing the product of greatest weathering and alteration occurring on the uneroded uplands during the long interglacial ages.

The lack of a gumbotil on the Iowan drift is due to incomplete weathering and chemical alteration, which in time, would change the oxidized and leached surface drift materials into the dense, tenacious, drab, deoxidized till residuum of typical gumbotil such as is found on earlier drift sheets. This incompleteness of the weathering processes is believed due solely to the shortness of time which has elapsed since the deposition of the Iowan till.

The evolution of the various phases of a drift undergoing the changes brought about by surface weathering agencies indicates that the first phase formed on a freshly deposited till is oxidized and unleached'till. Oxidation of the drab or dark-gray fresh till begins immediately upon exposure of the drift materials to the atmosphere. Beginning as quickly but progressing downward with extreme slowness, the process of leaching follows oxidation behind a widening interval of the oxidized but unleached till. Up.on the leached and oxidized surface of this second phase of change, the gumbotil develops only when a great length of time permits the chemical modifications necessary to remove the remaining soluble content, as well as colloidal clays and silicates from the already weathered drift. Time is the prime factor, with yariations in the original till lithology seeming to play but a minor part in the final residual product.

Insufficient time has elapsed since Iowan till deposition for the formation of an Iowan gumbotil horizon.

The, color of the oxidized and leached phase is predominently brown to dark brown. In mass texture this phase is sandy and pebbly and cuts readily. It is open-textured. In many places a concentrate of pebbles, the pebble band, is found at the top of this phase, formed as a residue of the surface material after the finer parts had been blown away as sand, silt, and dust. No distinct concentration of iron oxide, the ferretto zone, is found capping this upper phase of the Iowan till.

The clastic texture of the oxidized and leached Iowan till is slightly coarser than that of the same'zones of the three older tills, the Nebraskan, Kansan, and lllinoian, a fact which can be represented best by a comparison of the average analyses shown in figure 6 , page 34 . In the Iowan till the average percentage of material below 1/64 millimeter in diameter is about 32 in comparison to 48 
in the Illinoian, 39 in the Kansan, and 33 in the Nebraskan. The size grade between 1/32 and 1/64 millimeter in diameter. in the Iowan till is a minimum percentage of about 8 percent, while in the older tills this size grade is between 11 and 17 percent, one of the three largest percentages of the analysis.' About 50 percent of the material of the Iowan till is grouped into the size grades between $1 / 32$ and $1 / 2$ millimeter in diameter in comparison to about 49,43 and 32 percent in the Nebraskan, Kansan, and Illinoian respectively.

An average of the analyses of pebbles from oxidized and leached till from eight locations distributed throughout the Iowan drift area of this state is given in the accompanying table.

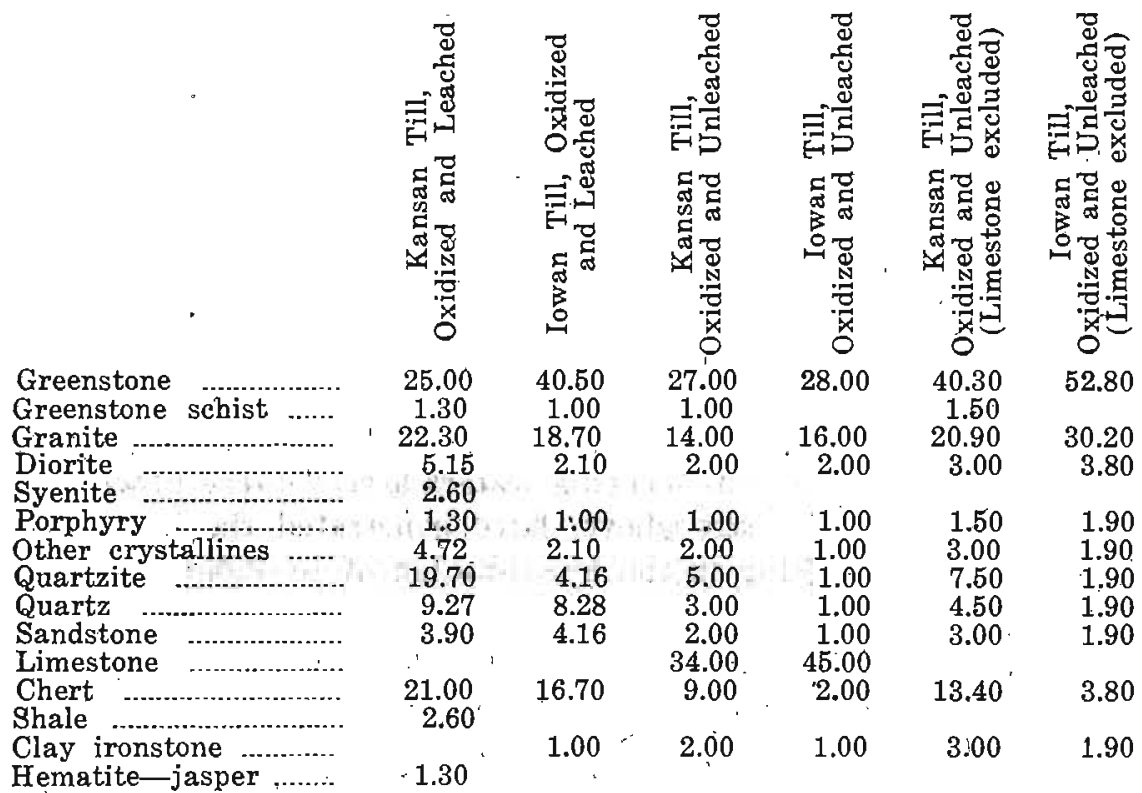

This analysis is very similar to an average of several analyses of the pebbles from the oxidized and leached zone of the Kansan till which lies directly below the Iowan till. The lack of limestone and other easily weathered rock common in fresh till is evidence that there has been alteration of the lithology and at the same time texture by chemical weathering. However, if one excludes the limestone and dolomite from an analysis of unleached and oxidized Iowan till, there is a difference in the percentages of the remaining types of rocks, as compared with the leached and oxidized, shown chiefly in a smaller percentage of such rocks as 
greenstones and granites and an increase in the percentages of quartzite and chert. To determine whether this was an accidental variable within the Iowan till, similar analyses were made using comparable analyses from the oxidized and leached and the oxidized and unleached Kansan till. The results of this study correlated very closely as shown in the preceding table.

From the study of the lithology and shapes of the leached and unleached Kansan till in comparison to the Iowan till, it may be concluded that the differences in size grades, determined by the mechanical analyses, are due to the differences in the clastic texture of the original material and are not the result of a greater amount of weathering and disintegration in the older tills.

\section{Oxidized-and Unleached Iowan Till}

The oxidized and unleached phase of the Iowan till is found below the oxidized and leached phase, set off by a narrow transitional zone in which the line of effervescence to acid traces the interfingering contact between the two phases. The two phases are not easily differentiated except with the aid of acid. The color of the oxidized and unleached till is yellow, being lighter colored as a whole than the yellow-brown till of the overlying oxidized and leached phase.

Concretions are frequent in this phase, and occur noticeably in the upper part, where lime-bearing waters active in the process of leaching in the till phase above; have penetrated the lime-filled unleached till, resulting in the precipitation of secondary calcium carbonate.

The till is open-textured, with no prominent system of joints, and in mass texture closely resembles the phase above.

There is a general similarity among the clastic textures of the oxidized and unleached Iowan till and the oxidized and unleached Nebraskan, Kansan, and Illinoian tills as shown in the average analyses in figure 6 , page 34 . In the Iowan till, about 30 percent of the material is included in the maximum size grade which is that finer than 1/64 millimeter in diameter. The next coarser size grade, $1 / 32$ to $1 / 64$ millimeter in diameter, contains only 8 percent. This is followed by a secondary maximum of 18 percent. The coarser size grades have a general decrease in percentage with increasing size grades.

There is a marked difference between the lithology of the oxidized and unleached and the oxidized and leached Iowan till. This 
difference is illustrated by a comparison of the pebble analyses of the two types in the table, page 137.-The most pronounced differences revealed by the comparison are in the presence of a very high percentage of limestone, a higher percentage of granites and greenstones, and a lower percentage of chert, quartzite, and other siliceous rocks in the oxidized and unleached till. These differences are all explained by the chemical weathering which will disrupt the more soluble constituents first, such as limestones, greenstones and granites, increasing the percentages of the less soluble siliceous rocks such as quartzites and chert. Further evidence that chemical weathering has not been active in the oxidized and unleached till is shown by the original shapes of even the most soluble fragments such as limestone. This is shown by striations, scratches, and bruises received during transportation, which are still on the surfaces of all types of material. Analyses of the shapes of the grains show practically no rounding by solution.

\section{Unoxidized and Unleached Iowan Till}

The basal phase of the Iowan till, the unoxidized and unleached phase, is frequently missing in sections of Iowan till due to the extreme thinness of the till sheet, allowing for oxidation to the base. However, several excellent sections show the unoxidized and unleached phase and a few of these have been previously described.

The unoxidized and unleached phase differs distinctly from the overlying phase in the color of the till, but in other respects is identical. The unoxidized till is gray on a dry surface, becoming dark gray to black when wet. Along the surfaces of the occasional joints extending down into this phase, oxidation has occurred which has outlined the joint system with the chocolate-colored veneer of incipient oxidation. As in the older tills the color line that is the oxidation line between the oxidized and unoxidized phases of the unleached till, is irregular, resulting in a zone of transition which may be several feet thick.

In mass texture, the unoxidized and unleached phase is more compact, less easily cut, more wisibly jointed, than the overlying phases.

The clastic texture of the unoxidized and unleached Iowan till is not distinctly different from the clastic texture of the oxidized and unleached Iowan till. The graphic representation of the mechanical analyses in figure 6 , page 34 , shows minor variations and 


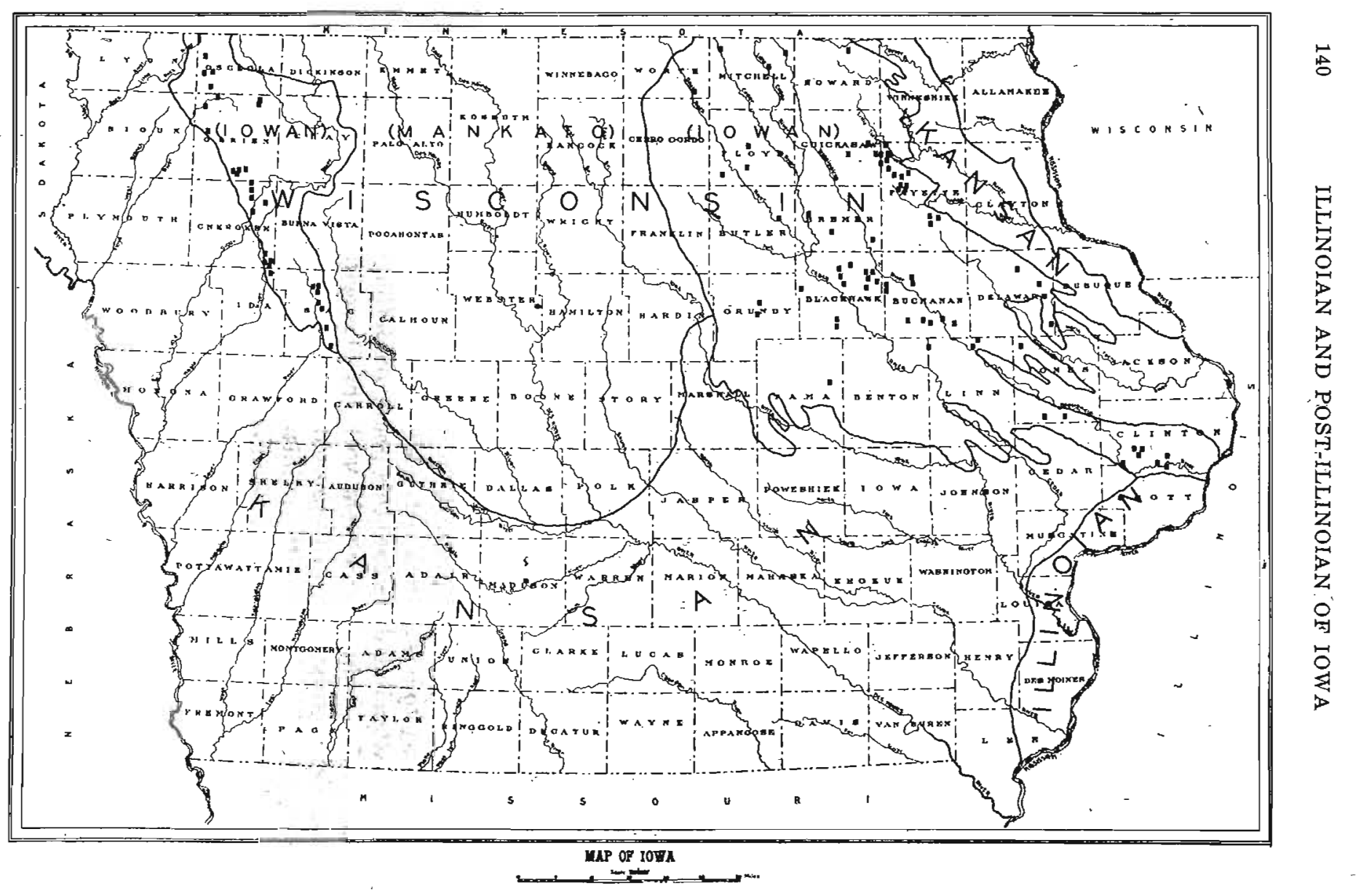

Figure 38. Map of Iowa showing the locations of Iowan upland gravels. 
irregularities between the two types of till but these are not greater than are commonly found within samples of the same type. Furthermore, any variations are not constant within different samples.

The lithology of the unoxidized and unleached till is the same as that of the oxidized and unleached till since the only difference in these tills is the oxidation of the iron compounds which does not change the rock content.

The shapes of the grains have been unchanged by weathering processes and thus represent the shapes at the time of deposition. The results of analyses of the size grades comparable to those used in the analyses of the lllinoian unoxidized and unleached till in figure 7 , page 35 , are almost identical to those of the Illinoian.

\section{Iowan Gravels}

The melting Iowan glacier deposited two general types of gravel which are Iound in many places within the area of the Iowan drift. These deposits, along with all other known Pleistocene gravel deposits of importance in the state, have been the subject of an exhaustive study by Kay and Miller. ${ }^{87}$ The discussion of the Iowan gravels which follows has been taken largely from their report.

\section{The Iowan Upland Gravel}

Kay and Miller have differentiated the Iowan gravels into Iowan upland gravel and Iowan terrace gravel, and on page 121 of the report cjited above have described the upland phase as follows:

"The deposition of the Iowan upland gravel is closely related to the retreat of the Iowan glacier and deposition of the Iowan till. The known exposures of the gravel occur at any one of the four general positions with respect to the Iowan till: (1) Several exposures show Iowan gravel interbedded with Iowan till. (2) A few are pockets' buried within the till. (3) Others are small kamelike knobs or hills which stand above the drift surface, and (4) many of them are pockets of gravel located near the tops of the hills, their upper surface almost at the same level as that of the drift."

Figure 38 is a map showing the location of Iowan upland gravels.

Since these gravels were deposited contemporaneously with the Iowan till, changes in them comparable to the changes noted in the Iowan till have taken place. Leaching has. occurred to an average depth of from 4 to 6 feet. Secondary calcium carbonate in the form of concretions and cement has been deposited below

\footnotetext{
9TKay, G. F., and Miller, Paul T., The Pleistocene gravels of Iowa: Iowa Geol. Survey, vol. 37, pp. 119-162, 1941 .
} 
the leached phase. Oxidation has stained the zones above the unaltered material to various shades of yellow or brown, the color being variable in keeping with the variation in the percentage of iron compounds inherent or carried into the gravel.

Stratification is apparent in most of the upland gravel deposits, but as is to be expected in gravels deposited directly by the glacier, there are such irregularities as clay-balls, boulders, inclusions of Iowan till or older material, etc. The gravels show considerable size range, most of the material being smaller than 6 centimeters in diameter, but there are many cobbles and boulders distributed through the gravel, some having an average diameter of more than 80 centimeters.

The percentage of each different size grade- in the various exposures, as determined by mechanical analysis, is shown in figure 39. The lithology of the pebble constituency of the same exposures falling within the 16 to 32 millimeter size range is shown in figure 40. These gravels may be found with a covering of Iowan till, Peorian loess, or both, or may lie at the surface. Usually they are thin, but have been found with a thickness of 15 or more feet.

A typical exposure of Iowan upland gravel oceurs in a pit in the SW $1 / 4$ sec. 22, Cedar Falls Township, (T. 89 N., R. 14 W.), Black Hawk County, 2 miles west of Cedar Falls. The gravel is exposed along the hillside in an area having a relief of about 75 feet. The section is as follows:

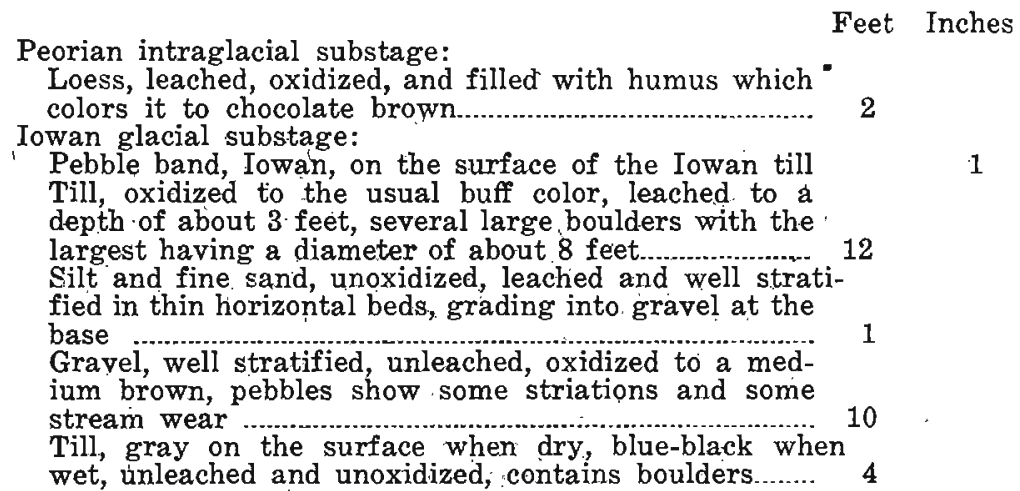

Calcium carbonate in the loess and Iowan till above the gravels has been leached to a depth of a little more than 5 feet, which is about the average for Iowan materials. There is some disintegration to be seen in the crystalline pebbles. The material is largely sand and gravel finer than 3 centimeters in diameter. Samples 

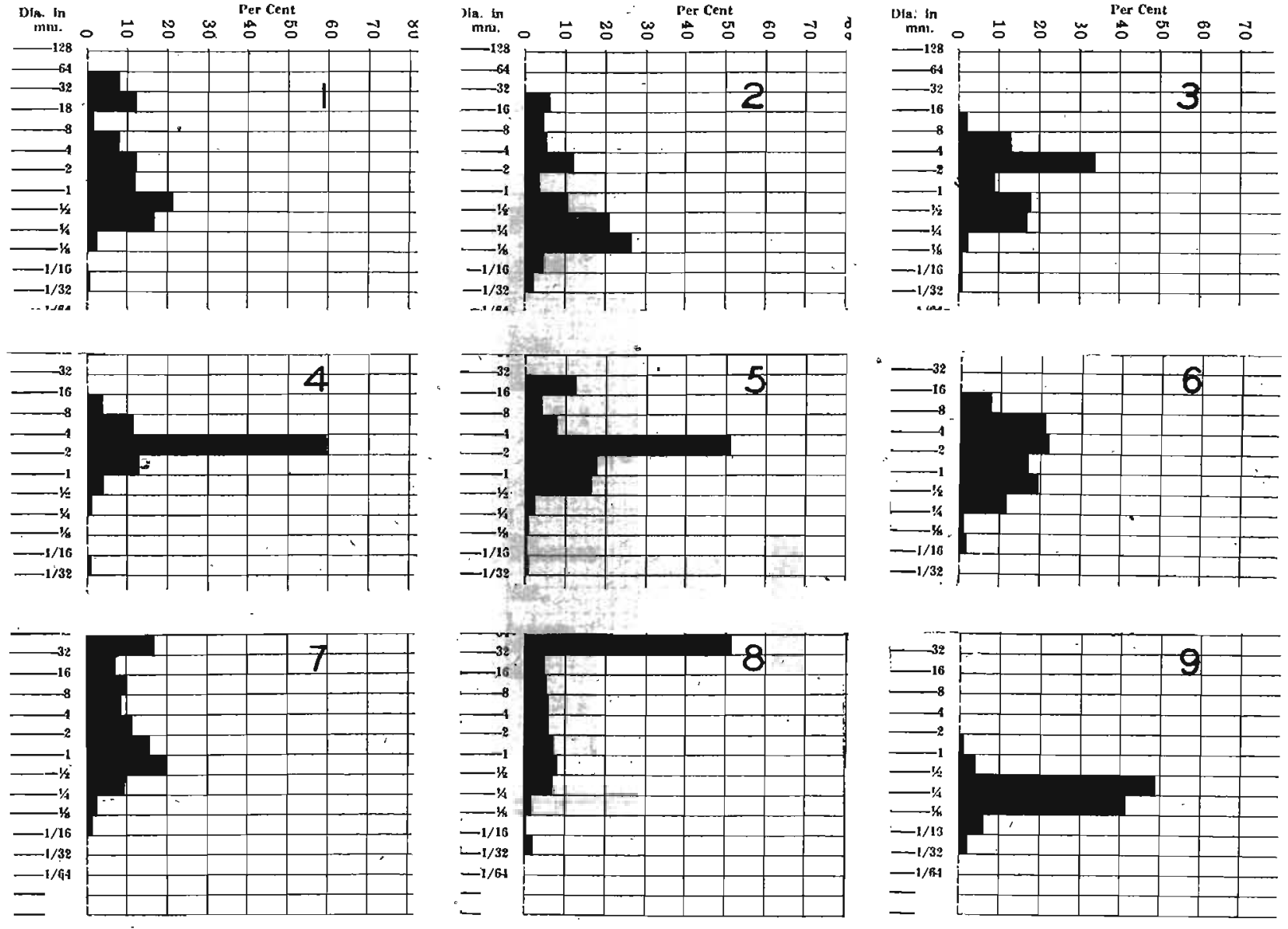


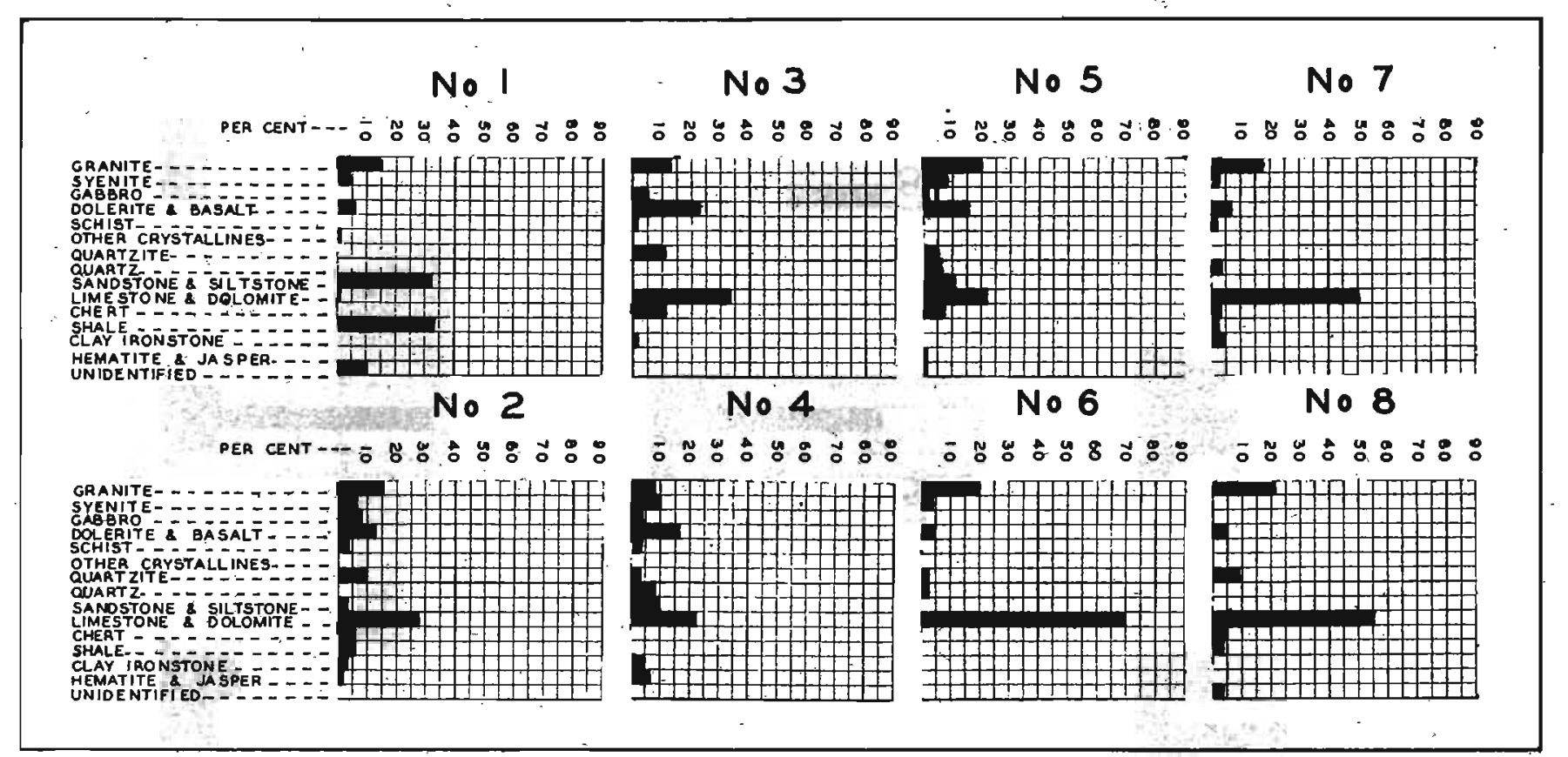

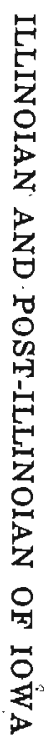

Figure 40. Graphs showing the lithological analyses of Yowan apland gravels within the size range 16 to 32 millimeters in diameter. 
nos. 1 of figures 39 and 40 represent the size percentages and lithologic content respectively of the section.

Another exposure of Iowan upland gravel is in the NE1/4 sec. 35, Wayne Township, (T. 100 N., R. 15 W.), Mitchell County, about one-half mile east of McIntire. These gravels overlie both Kansan gravel and Loveland loess. Above the gravel deposit lies Iowan till with a maximum thickness of $\mathbf{5}$ feet, here unleached in the basal part.

The Iowan gravel is here 2 to 5 feet thick, oxidized light brown, and slightly adherent with iron oxide. It is horizontally bedded in general, but with poor sorting, with some steeply dipping beds. In size the gravel is mostly finer than 5 centimeters in diameter, but cobbles are found ranging up to 15 centimeters in diameter, some of which show striations. The size grade percentages and pebble lithology of this section are graphically shown in nos. 3 of figures 39 and 40 .

In northwestern Iowa, gravels and till of Iowan age were described in great detail by Carman. ${ }^{88}$ One of the finest exposures of gravels in the Iowan till to be found in the state is described in his report as follows:

\begin{abstract}
"By far the greatest example of interbedding of gravel and till observed was found in the east bluff of Mill creek in the west half of section 14, Cherokee township, three miles north of Cherokee. Mill creek at this place flows against the base of the east slope of its valley, and this slope rises very steeply 100 to 120 feet to the crest of a narrow ridge which overlooks the valley of Mill Creek on the west and the Little Sioux valley on the east. The good exposures just south and north of the line through the center of section 14, were distributed through a distance of about 80 rods, and were found in little gullies and slides that gave exposures of the underlying material. The lower 30 to 40 feet of the valley slope is gentle but showed a few exposures of typical Kansan till. Above this is' a steep slope' of 75 to 100 feet, consisting, of about equal parts of interbedded Iowan till and gravel which alternates several times in the vertical section. The gravel horizons range in thickness from mere seams to 20 feet, but a common thickness is 10 to 15 feet.

"Most of the gravel is fresh and has a light color owing to the predominance of gray limestone pebbles. It contains many clay-ball pebbles from associated Iowan till and some of Kansan' and Nebraskan tills. The interbedding of gravel and till and the presence of the clay-balls of the associated till in the gravel show that the gravel belongs to the same stage as the till:"
\end{abstract}

Carman's detailed sections which were included with the discussion of this locality. indicate two, three, and four important gravel horizons which, to all appearances, were not continuous. All the gravels as well as the interbedded till are fresh. Clayballs which occur in great profusion in the gravel lenses, seem to

Ba Carman, J: E., Further studies on the Pleistocene geology of northwestern Iowa: Iowa Geol. Survey, vol. 35, pp. 21-187, 1981. 


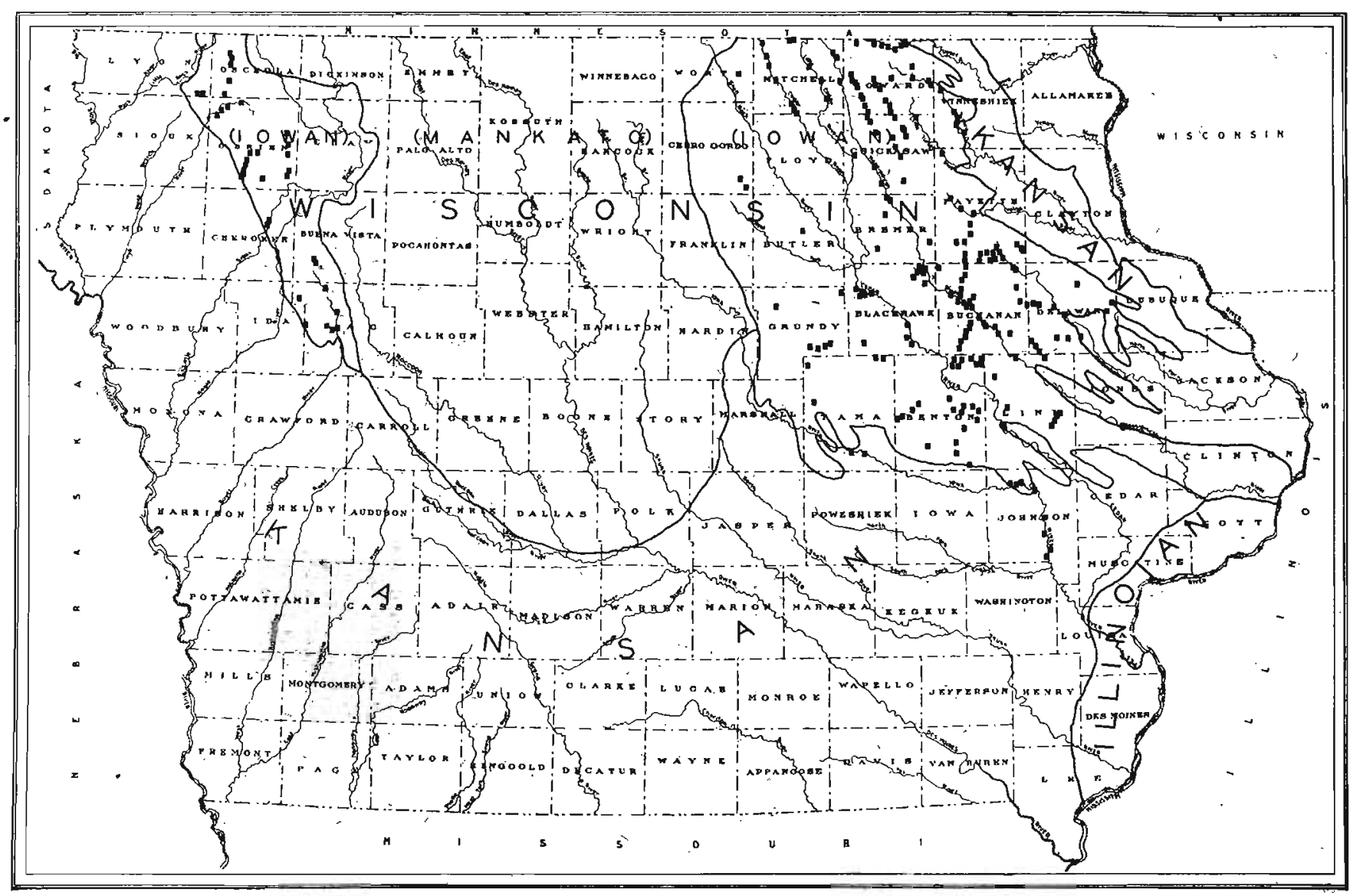


indicate that the materials had not undergone great transportation before deposition, as the clay masses, even though frozen, would not have survived the wear of any considerable transportation. As this location is near the western margin of Iowan ice extension, this interphasing of Iowan till and gravel would seem to reflect the fluctuating action of the glacier terminus, with successive advances and retreats depositing till and gravel in turn.

The age of the Iowan upland gravel may be determined by the relation of the deposits to the Iowan drift and by the amount of alteration the gravel has undergone where the cover conditions are known. All of the deposits are closely associated with the till, either as masses within the till, or as outwash on its surface.

\title{
The Iowan Terrace Gravel
}

Terrace gravel of Iowan age occurs quite generally in the valleys of streams which flow within, or head within the area covered by the "Iowan drift (fig. 41). They have been interpreted by Kay and Miller ${ }^{89}$ as follows :

\begin{abstract}
"The Iowan ice advanced over the eroded surface of the Kansan drift and deposited a thin layer of till which was spread over this surface like a blanket. These older valleys were not filled by this Iowan till but served as drainage courses for the streams flowing from the melting ice that carried sand and gravel which was deposited along these valleys within and beyond the Iowan drift area. However, in northwestern Iowa, some of the valleys that were exoded in the Kansan drift did not extend into the area covered by the Wisconsin glacier and thus did not receive drainage from either the Iowan or Mankato ice sheets. However, these valleys contain extensive gravel terraces, the gravel having been derived from the eroded material of the drift during the Loveland interval. Valleys of the same origin and age extended into the Iowan drift area carrying drainage from the melting ice and receiving the glacio-fluvial outwash carried by the streams. It is evident that in northwestern Iowa at least some Loveland gravel was in the valleys before the advance of the Iowan glacier and constitutes part of the gravel fillings. The Loveland and Iowan terraces are so similar that they cannot be differentiated except on the basis of relations to surrounding materials and location in relation to source material. It is probable that the valleys whose heads lie within the Iowan drift area contain gravel of both lowan and Loveland ages which cannot be differentiated, and in these valleys there is no doubt but that they contain Iowan gravel beyond the Iowan drift margin. Since it is certain that the Iowan gravel forms most of the terrace material within the Iowan area and since the presence of Loveland gravel has not been proven, these terraces will be mapped as Iowan. However, beyond the Iowan drift margin, all of the evidence is in favor of the Loveland gravel forming part of the deposit, even though it may be partly reworked by the streams which deposited gravel as they flowed from the Iowan glacier."
\end{abstract}

Since the deposition of the Iowan terrace gravel, the streams have in general entrenched themselves in the gravel fillings,

${ }^{80} \mathrm{Kay}, \mathrm{G} . \mathrm{F}$, and Miller, P. T.; The Pleistocene gravels of Iowa: Iowa Geol. Survey, vol. 37, p. 144, 1941 . 
leaving remnants of the gravel floor as terraces which in some localities are as much as. 100 feet above the present stream level. A typical exposure of Iowan terrace gravel is shown in figure 42. The gravel deposits may lie upon Iowan or older till, and may be overlain by coarse, unstratified, sandy silt with pebbles in the basal part, or by Peorian loess, or both. The thickness of the overburden averages about 3 feet, but ranges from 6 inches to more than 6 feet. Nowhere has there been found evidence of a time interval between the deposition of the gravel and that of the overlying material.

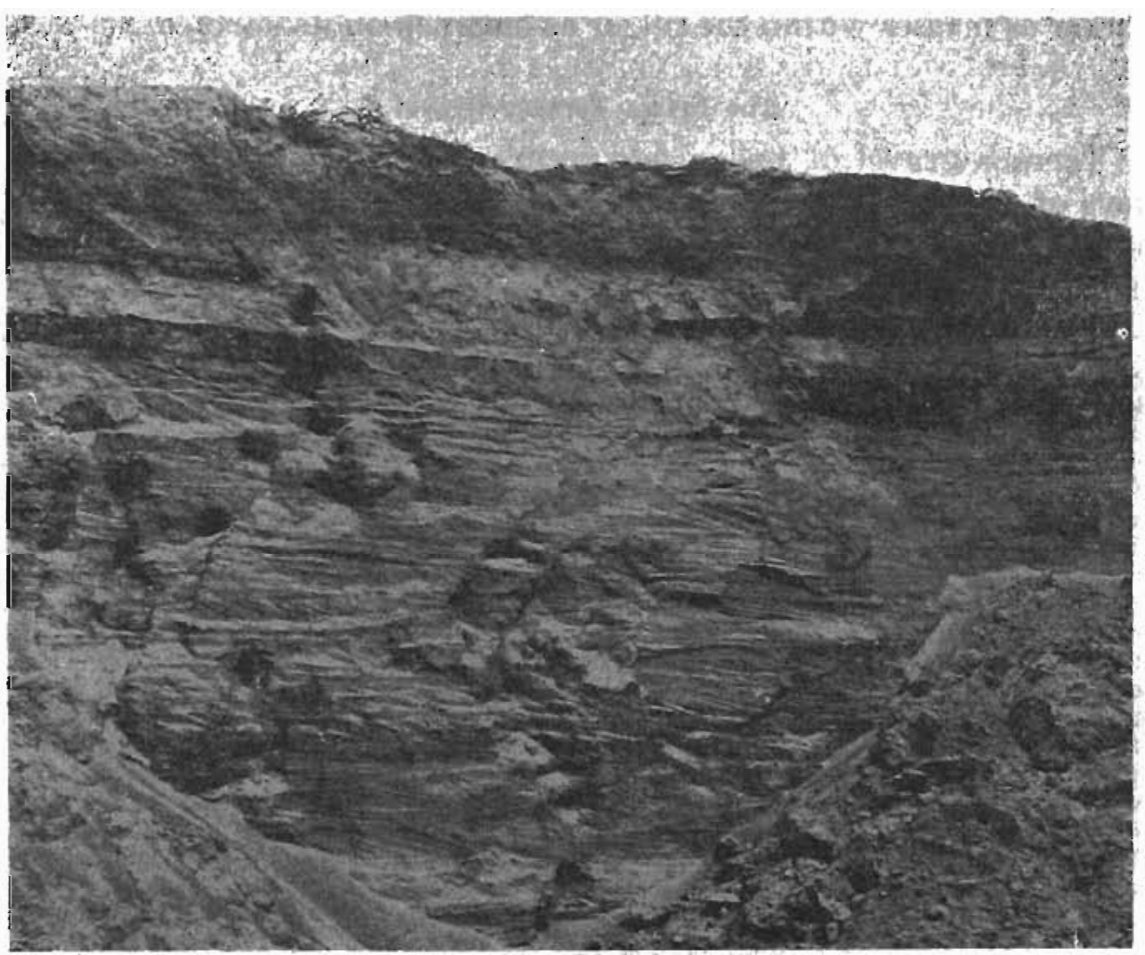

Figure 42. Terrace gravel of Iowan age near Iowa City, Johnson County.

As with the Iowan upland gravel, changes due to weathering have occurred in the terrace gravel, but with greater variation of depth. This variation is thought to be due not primarily to differences in the amount of leaching, but to lithology, topographic position, and subsequent erosion. In those deposits where the lith- 


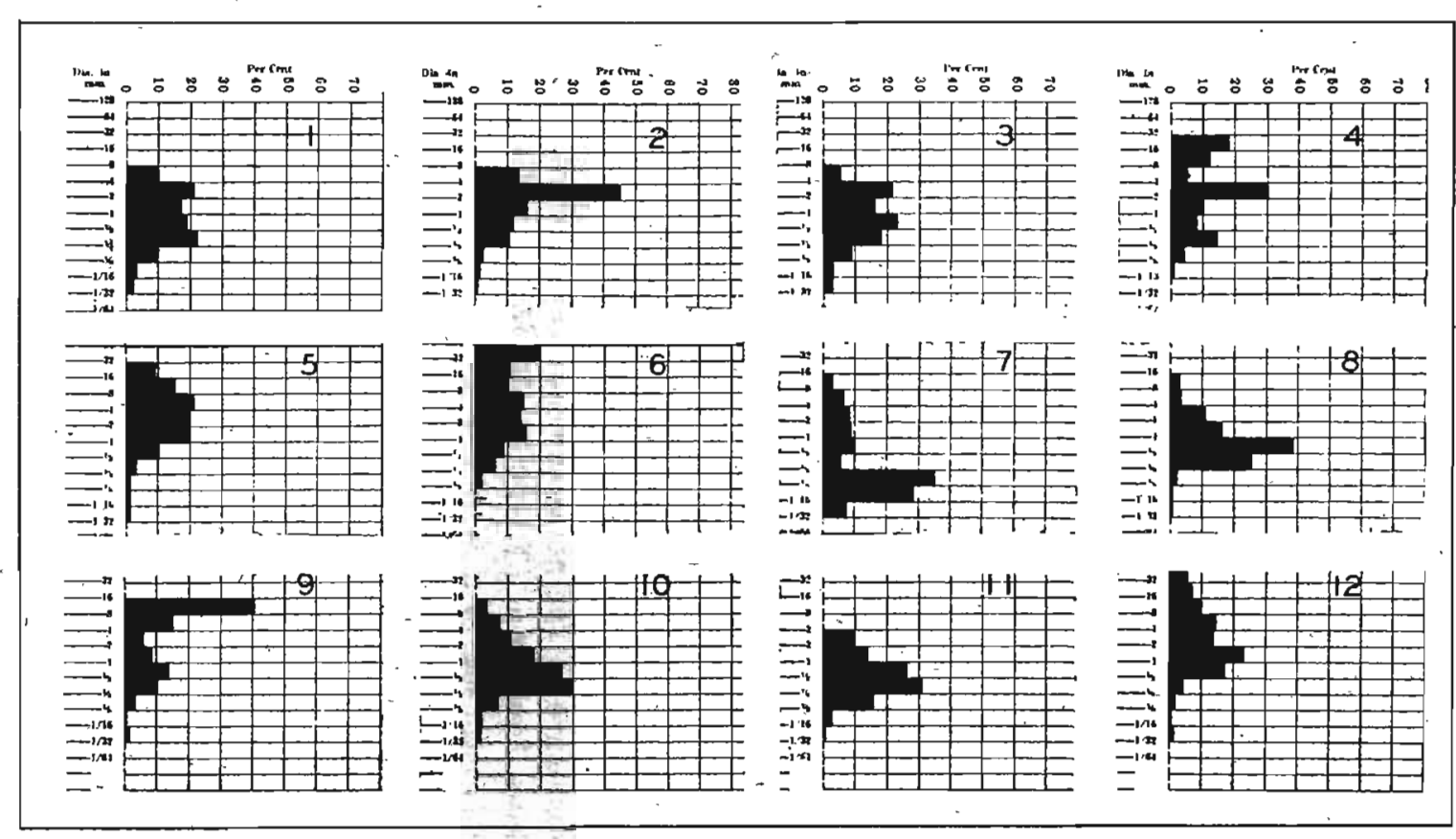

Figure 43. Grapbs showing mechanical analyses of lowan teraace gravel. 
ology and texture of the terrace gravel is comparable to the upland gravel, the depth of leaching is 4 to 6 feet, as in other materials of Iowan age. The slightly greater depth of leaching found in many of the terrace deposits may be due to greater freedom of ground-water circulation.

The terrace gravel appears fresh, and only occasional cobbles or boulders show any disintegration. No cementation was noted in any of the exposures. In grade size, the terrace gravel is mostly sandy, as is shown in the mechanical analyses of figure 43 . The lithology of the pebbles occurring in the 16- to 32-millimeter range in diameter is shown in figure 44 . The lithology of the terrace gravel differs from the upland gravel in lacking the clay-ball content, and in having a higher content of siliceous and resistant igneous rocks. The color varies from gray unoxidized gravel to dark brown resulting from iron oxide stain. The gravel is normally well stratifed in horizontal beds, and usually contains two members, a finer, more sandy phase below, and a coarser, more gravelly phase above. The first is rarely used for commercial purposes.

In the detailed work of Kay and Miller on the gravels of the state, it was found that the Iowan terrace gravel could be roughly separated into deposits of a (1) highly siliceous character; (2) deposits with intermediate calcareous and siliceous content; and (3) deposits of a highly calcareous nature.

A good exposure of the noncalcareous type occurs in the NW1/4 sec. 2, Jenkins Township, (T. 100 N., R. 15 W.), Mitchell County. The gravel is exposed to a height of 30 feet above the level of a tributary of Wapsipinicon River, one-half mile south of McIntire. Fifteen feet of unslumped gravel is exposed. The overburden consists of sandy, loess-like silt, ranging from 1 to 2 feet in thickness.

The gravel is oxidized to a light or reddish-buff color. No carbonates, either primary or secondary, are found. The gravel is fresh in appearance. The upper 5 feet is largely sand in thin horizontal beds. The lower material is also fine, but with a greater percentage of pebbles and lenses of coarse material. Nothing within the exposure was found to exceed 3 centimeters in diameter, and less than 4 percent is larger than 8 millimeters in diameter. The size grade percentage and the lithology of this section are given as graphs no. 1 in figures 43 and 44.

The intermediate type of Iowan terrace gravel which contains a considerable amount of both siliceous and calcareous material, 
is the most common type of deposit. The gravel is normally oxidized buff colored, and leaching has removed the carbonates to a depth of 5 to 6 feet. The gravel is fresh in appearance.

In the SE $1 / 4$ sec. 35 , Colfax Township, (T. 88 N., R. 17 W.), Grundy County, along. Black Hawk Creek south of Holland, this type of gravel is exposed in a terrace standing 18 feet above the stream. Six feet of gravel is overlain by 4 feet of Peorian loess. The gravel is light buff in color. Leaching has removed the carbonates from the 4 feet of overlying loess and from the upper 1 foot of gravel. Below the leached zone are many concretions of secondary lime and pebbles of limestone and dolomite. The gravel is poorly sorted, with a textural range up to 3 centimeters, but mostly below 1 centimeter in diameter. The bedding is horizontal in general, with some cross bedding. The textural range and lithology of this exposure are graphically shown in graphs no. 7 of figures 43 and 44.

Highly calcareous terrace gravel of Iowan age is fairly common in both northeastern and northwestern Iowa. The limestone and dolomite content usually' occurs as large angular fragments up to 30 centimeters in diameter.

A good example of this type of gravel is in a gravel pit in the east side of Sibley in the NW1/4 sec. 18, East Holman Township, (T. 99 N., R. 41 W:), Osceola County, near the valley of Otter Creek. Here the terrace lies approximately at the upland level and several gravel pits have been opened near the stream, both east and south of Sibley. Carman ${ }^{90}$ studied some of the older of these pits in detail.

A new exposure in this terrace shows 20 feet of highly ironstained, dark-buff gravel, uniform in oxidation to the bottom, although Carman's sections of nearby pits show a considerable variation in oxidation with depth. What disintegration is apparent in the pebbles occurs principally in the gray shale content. Leaching has occurred in the 3 feet of typical Peorian loess overburden, but none of the gravel is leached, and-oxidized and unleached till, presumably Iowan, underlies the gravel. The major bedding of the gravel is horizontal, but thinner cross-bedded phases show dips at various angles. The lenses and pockets within the gravel are almost entirely of gray shale. The textural range and lithology of the pebbles are given in the analyses listed as graphs no. 5 in figures 43 and 44.

${ }^{00}$ Carman, J. E., Further studies on the Pleistocene geology of northwestern Iowa: Iowa Geol. Survey, vol. 35 , pp. 141-144, 1931. 
The age of the gravels described in the sections given above cannot be determined with the same definiteness as certain other Pleistocene gravels of the state may be dated. They are known to have been deposited in valleys formed in the post-Kansan gumbotil preIowan interval, and in such places as they have been observed lying on, or interbedded with Iowan till, are Iowan in age. Where the gravels are overlain by Peorian loess, no evidence of weathering of the gravels, or any transition zone between the two indicating an interval of time, is to be seen. However, as has been stated, a part of the gravel may be Loveland in age, either rehandled by Iowan meltwater during Iowan glaciation, or as an indistinguishable part of the terraces which received their final deposits in Iowan time.

Fossils of late Pleistocene age have been found in the Iowan terrace gravel, and a few of these principally the vertebrate fauna, have been mentioned by Carman. ${ }^{91}$ The junior author made a brief investigation of the terrace levels in several of the western border counties, in an attempt to determine the southern extent of these Iowan fossil-bearing terrace gravels. Some of the vertebrate forms brought from this region to early paleontologists and ascribed by them to deposits then thought to be Aftonian gravels, would now seem to be more representative of more advanced types which are found in the Iowan gravel terraces.

\section{Thickness of the Iowan Drift}

With the possible exception of a narrow overlap of the Iowan on, Illinoian drift in northern Scott County, the Iowan drift lies on a region previously covered by Kansan drift. Hence the materials of the Kansan drift lay at the surface in the Iowan area, subject to the various processes of weathering and erosion for the great length of time represented by the Buchanan interval. This interval, named by Calvin for deposition or weathering in the Iowan area occurring on Kansan drift before Iowan glaciation, includes the long Yarmouth interglacial, the Illinoian glacial, and the Sangamon interglacial ages, and represents in actual time, more than half of the estimated duration of the Pleistocene period in Iowa. Therefore, the surface over which the thin Iowan glacier moved was a region with well developed erosional features. By Iowan time, the surface had been denuded in places to expose bed-

\footnotetext{
${ }^{\text {MCarman }}$ J. E., op. cit., pp. 164-166.
} 
rock or its weathered derivatives, Nebraskan drift, Aftonian deposits, or various phases of the Kansan drift. In other places, the till or'bedrock materials were covered in Sangamon time by Loveland loess.

The topography of the whole was typically erosional, with marked stream dissection forming broad, mature valleys with gentle and smooth slopes. Areas of undissected upland-the Kansan gumbotil plain-were present in places at the time of Iowan ice invasion. The landscape was without great relief. Only locally did small outcrops of bedrock form small gorges along the otherwise mature drainageways.

Upon this erosional topography which was developed on Kansan and older drift materials during the Buchanan interval, the Iowan drift was spread as a thin mantle, partially filling the valleys, smoothing the relief, and exhibiting only occasional constructive features entirely Iowan. This veneering of the mature Kansan landscape by the thin but distinctive Iowan drift gave the "gentle rolling" topography which is so characteristic of a large part of the northeastern Iowan portion of the state. Presumably this same "gentle rolling" drift-mantled erosional topogrâphy 'extended on west and characterized the Iowan drift surface now covered by the Mankato lobe of the Wisconsin stage though northwestern Iowa gives evidence of upward warping which has resulted in extensive erosion of the drift materials. This, and the covering of loess of Peorian age which was blown over the triangle of Iowan drift lying west of the Mankato lobe, has somewhat modified the expected similarity to the eastern part of the Iowan lobe in northeastern Iowa.

In view of these existing field relations, it has been difficult to get a true average for the thickness of the Iowan drift. Calvin, ${ }^{92}$ whose careful observations and long familiarity with the Iowan drift have kept his reports on this subject as important references today, reported neighboring sections with depths ranging from 1 to 30 feet. Calvin suggested that large areas of the drift would average less than 10 feet in thickness.

The thickest sections of Towan drift are in the constructional areas of the drift margin. Such a section is along the north line of sec. 16, Windsor Township, (T. 94 N., R. 9 W.), Fayette County. This cut is in the marginal moraine, and the hills just south of the

${ }^{82}$ Calvin, Samuel, The Iowan drift: Geol. Soc. America Bull., vol. 10, pp. 112-113, 1900. 
cut which exposes Iowan till lying on Kansan gumbotil, rise 37 feet above the gumbotil level. This thickness is all Lowan till.

Near Clarence in Massillon Township, (T. 82 N., R. 1 W.), Cedar County, and along the south edge of the Clinton lobe of the Iowan drift, the Iowan till attains a thickness of about 45 feet, this depth being based on the height of the Iowan till surface above the level of the underlying Kansan gumbotil.

An even thicker section of Iowan drift is in sec. 19, Beaver Township, (T. 89 N., R. 16 W.), Grundy County, about 2 miles north of Fern. Kansan gumbotil is exposed in a cut along the north part of the road between sections 19 and 20 . To the southwest of this cut there is considerable relief in the Iowan till, measuring about 60 feet from the gumbotil level to the top elevation of the Iowan knoll.

Another section, previously described, which shows an unusual thickness of Iowan drift is located nearly in the center of the northeastern Iowan drift region. It is in a gravel pit about 2 miles southwest of the Iowa State Teachers College at Cedar Falls, in the NE1/4, sec. 27, Cedar Falls Township, (T. 89 N., R. 14 W.), Black Hawk County. The section exhibits 23 feet of Iowan till, in which all of the Iowan till phases are represented. The base was not exposed.

However the great majority of Iowan till exposures range from 1 to 7 or 8 feet, and the average thickness of the till probably does not exceed 10 feet. The extreme thinness of the till of a glacier as extensive as the Iowan is known to be, coupled with the digitate form of the southeastern margin of the drift and the Kansan islands within the till border, all demand an explanation.which has not as yet been adequately formulated. That the till is present; that it manifests certain conditions of weathering and erosion; that its lobate boundaries are where they have been mapped; that on its surface are many large boulders; that the till thickness is no thicker than is shown by the average of the great number of known sections, widely distributed;-all these are facts of observation. Such a combination of features will continue to invite satisfactory interpretations from all studenţs of glacial phenomena.

THE PEORIAN INTRAGLACIAL SUBAGE (SUBSTAGE)

Classification of Peorian intraglacial subage (substage)

The Peorian loess

Distribution and topographic expression of the Peorian loess in Iowa Loess mantled erosional topography 
Loess depositional topography

Typical sections of the Peorian loess in Iowa

Characteristics of the Peorian loess

General characteristics

Mechanical analyses

Mineral analyses

Chemical analyses

Fossils in the Peorian loess in Iowa

Vertebrates

Invertebrates

Depth of leaching in the Peorian loess

Thickness of the Peorian loess in Iowa

Comparison of the Peorian loess with the Loveland loess

Classification of the Peorian Intraglacial Subage (Substage)

In the classification of the Eldoran epoch (series) of the Mississippi Valley, Kay and Leighton include two ages (stages), the Wisconsin glacial age (stage), and the Recent interglacial age (stage). The Wisconsin glacial age (stage) includes four subages (substages), the Iowan (Oldest Wisconsin), the Tazewell (Early Wisconsin), the Cary (Middle Wisconsin), and the Mankato (Late Wisconsin). In this classification the name Peorian does not appear. Leighton and his associates had shown that there was continuous deposition of loess from Iowan time until after Early Wisconsin time, and furthermore that the interval heretofore called Peorian was so short as to necessitate its elimination as an interglacial age from the classification of the Pleistocene in Illinois.

In Iowa the record of the Wisconsin age is less complete than in Illinois. Here the Tazewell and Cary substages of the Wisconsin stage are absent. The Iowan substage is separated from the Mankato substage by a widespread loess which for many years has been mapped as Peorian loess, and the time of deposition of the loess and the time of weathering of the loess prior to the deposition of the Mankato drift has been called the Peorian intraglacial age.

In the revised classification of the Wisconsin age Kay and Leighton ${ }^{98}$ make the following statement with regard to the usage of the name Peorian in Illinois and in Iowa:

"The name Peorian will continue to be used in Iowa for the widespread loess which lies on the Iowan drift and around its border, and beneath the Mankato (Late Wisconsin) drife; and in Illinois for the widespread loess which lies above the Late Sangamon loess outside of the Tazewell drift. Within the border of the Tazewell drift the loess which-immediately underlies it may be called Iowan, as originally proposed, and the loess which overlies it, the Tazewell loess. These two loesses are indistinguishable outside of the Tazewell drift border and compose the Peorian loess.'

פKay, G. F., and Leighton, M. M., Eldoran epoch of the Pleistocene period: Geol. Soc. Amerter Bull., vol. 44, pp. 669-673, 1983 . 
The Peorian interval in Iowa is now interpreted to be an intraglacial subage rather than as previously, a short interglacial age. As formerly, the Peorian interval will include the time of deposition of the widespread loess which is interpreted to be Iowan in age and the time during which this loess underwent weathering prior to the deposition of the Mankato drift. In Illinois the Peorian loess includes loess of Iowan age and of later Tazewell age. Thus far it has not been possible to differentiate the two loesses outside the Tazewell drift border. In Iowa, although the Peorian loess appears to be a unit formation of Iowan age, it may be that future investigation may be able to show that the upper part of the loess is as young as the Tazewell loess.

\section{The Peorian Loess}

McGee, ${ }^{94}$ in his final report on northeastern Iowa, and in earlier papers, interpreted the loess to be aqueous in origin. He correlated the widespread loess deposits in northeastern, southern, and southeastern Iowa with his Upper Till, calling them loessdrift or drift-loess. After the Upper Till had become known as Iowan till the loess related to it was called Iowan loess. This was the usage in Iowa and in Illinois.

The name Peorian was used first by Leverettor who applied it to the weathered zone at the contact between the Iowan loess and the Wisconsin till in Illinois. In an exposure-the Farm Creek Section-east of Peoria, there was evidence of an interval of weathering between the time of deposition of the loess, which was correlated with the.Iowan till, and the Shelbyville till sheet, which appeared to be the earliest of the Wisconsin series. The interval was named the Peorian interglacial interval.

Calvin in $1899,{ }^{06}$ accepting the aqueous theory of origin of loess made the following statement:

\footnotetext{
"The geographical distribution and physical characteristics of the typical loess of northeastern Iowa suggest genetic relationship with the Iowan till. That it was in some way derived from the till when the Iowan ice invasion was at its maximum is indicated by many lines of evidence. The main body of the loess was all extra-marginal. Over no considerable area is typical loess ever found resting on Iowan drift It lies thickest just at the margin of the region occupied by Iowan ice at the time of its maximum development, and is spread widely but not uniformly, over the extra-marginal space to distances at present undetermined. Loess, or a product resembling loess,

MMcGee. W T. The Pleistocene hiatory of northeastern Iowa: U. S. Geol. Survey IIth Ann. Rept., pp. 199-586, 1891

Weverett. Frank, The Peorian soll and weathered zone (Toronto formation?) : Jour. Geology, vol. 6, pp. 244-249, 1898.

Calvin, Samuel, The Iowan drift: Geol. Soc. America Bull., vol. 10, pp. 107-120, 1899.
} 
was developed in connection with more than one drift sheet and it is possible that the Iowan loess blends into loess-like deposits of different age in some portions of the extra-marginal territory."

A few years later Shimek ${ }^{97}$ presented evidence in support of the interpretation that the loess which was being called Iowan loess was not aqueous but chiefly eolian in origin, and that the fossils of the loess indicated that the loess was not glacial in age but was deposited after the retreat of the Iowan ice sheet and hence was interglacial in age. The eolian origin soon was accepted quite generally and the loess was interpreted to be not contemporaneous in age with the Iowan drift but somewhat later in age than the Iowan. With this change in interpretation, the loess began to be called Peorian loess because it had been deposited in the interglacial age between the Iowan and Wisconsin glacial ages. This application of the Peorian although not in accord with the meaning given to it originally by Leverett was adopted generally and apparently without adverse criticism. This was the view of Calvin $^{98}$ in 1911 . He states:

\footnotetext{
"The earlier view was that the loess was' deposited at the time of maximum development of the Iowan glaciation, when the Iowan area was still covered by ice. The only modification of that view at the present time is that loess deposition took place after the Iowan ice had retreated to a greater or less extent, after an interglacial interval had actually begun. By such retreat extensive mud flats were left, and as these dried before becoming covered with vegetation, strong winds coming, probably, from the ice fields farther to the north, carried fine sand and dust from the bare surfaces and deposited them beyond the edge of the Iowan area, out upon the old eroded Kansan..... The genetic relation of the loess to the Iowan drift is not so very unlike the corresponding relation of the Buchanan gravels to the Kansan; and so far as the genetic relationships are concerned, there has been no abandonment of the view originally proposed.

"The color, composition, and calcareous content of the Iowan loess are in perfect accord with the hypothesis just expressed; its geographic distribution around the lobed margin of the Iowan area agrees also. with the view; the great thickness of loess in or at its inner margin, and its thinning out with increasing distance from the source of supply, corroborate all the other lines of evidence; while the great amount of eolian sand associated with it in a narrow belt surrounding the lobes of Iowan drift lends additional support. The Missouri river loess and all other loess deposits which have evidently been derived from the broad flood plains of nearby rivers, have a similar distribution relative to their source; they are thickest and coarsest near the gathering ground and become thinner as the distance from the base of supply increases. All the facts connected with the origin, composition, and distribution of the loess are perfectly explicable without resorting to the hypothesis that ' $\mathrm{a}$ considerable' part was derived from the great plains east of the Rocky Mountains.' Studies in the field afford overwhelming evidence that, genetically and geographically, the Iowan drift has very intimate relations to certain bodies of loess."
}

92Shimek, Bohumil, Loess and the Iowan drift: Iowa Univ. Studies in Nat. History, vol.

5. pp. 856-368, 1904. The Iowan drift: Jour. Geology, vol. 19, pp. 601-602, 1911. 
This was also the view of Alden and Leighton in their report on the Iowan drift in the 1915 Annual Report of the Iowa Geological Survey.

Leverett ${ }^{99}$ in a paper published in 1926 stated:

"Features of the Iowan drift and its relations to the loess seem to demand further critical field study."

His viewpoint as expressed in this paper was that the Iowan drift should be correlated in age with the Illinoian drift and that a pebble band on the Iowan drift and beneath the loess is the result of slope wash rather than of wind action. He thinks that a great length of time was necessary for the development of this pebble band, and hence the loess overlying the pebble band must be very much younger than the Iowan till upon which the pebble band lies.

Kay ${ }^{100}$ replied to the arguments of Leverett as has been stated somewhat fully already on pages 96 to 97 . Leighton eliminated the Peorian from the classification of the Pleistocene in Illinois. His evidence for this interpretation was that the Peorian loess had been deposited continuously from Iowan time until after Early Wisconsin time and hence there was no distinct Peorian interval. In Illinois, as previously stated, Peorian is now used for the widespread loess which lies outside the Tazewell border, and in Iowa the Peorian is used for the widespread loess of Iowan age and for the time of weathering between the deposition of the loess and the Mankato drift.

When the fossils of the Peorian loess are discussed it will be shown that the fossil evidence is now interpreted to be consistent with a glacial origin of the loess rather than with an interglacial origin.

The history just outlined shows clearly that the many persons who have studied the Peorian loess have differed in their interpretation with regard to its origin and age. At present there is agree ment as to the eolian origin of the loess but some difference of opinion continues regarding its relation to the Iowan till.

Q0everett, Frank, The Pleistocene glacial stages: Were there more than four? Am. Phil Soc. Proc., vol. 65. no. 2 , 1926.

100Kay, G. F., The relative ages of the Iowan and Illinoian drift sheets: Am. Jour: Sci., vol. 16, pp. $497-518,1928$

Kay, G. F. The relative ages of the Iowan and Wisconsin drift sheets: Am. Jour. Sci., vol. 21 , pp. $158-172,1931$. 
Distribution and Topographic Expression of the Peorian Loess in Iowa

The Peorian loess of Iowa has not been distrlbuted evenly over all of the state. Due to the localized nature of the two main source areas of the loess material, namely the valley of the Missouri River and the Iowan drift sheet, certain sections of the state have received a considerable thickness of the windblown material, while other regions more removed from the important sources, received only enough to thinly mantle the surface of the drift or bedrock.

This difference in loess thickness has resulted in two main types of loess typography over the state; one, the so-called loess mantled erosional topography which presents an old erosional topography which has been modified but not obliterated by the loess mantle; and second, loess depositional topography, exhibiting a topography with forms attributable entirely to the loess, the former surface having been buried too deeply to lend expression to the present surface (see fig. 27, page 104). These two principal types of loess topography will be described briefly. ${ }^{101}$

\section{Loess Muntled Erosional.Topography.}

Loess may influence an erosional topography in at least three ways: it may increase the relief by the deposition of more loess on the divide areas than in the valleys; it may reduce the relief by the deposition of more loess in the valleys than on the divide areas; and the distribution of the loess may be such that the amount of the relief is not distinctly changed, and yet by altering the angles of slope and by building on the hillsides, a modified topography may be developed. All these types of modification are found in the state.

The boundaries of the loess mantled areas are necessarily somewhat arbitrarily drawn. It is more difficult to decide on a proper boundary where the loess thins gradually. than where it thins somewhat abruptly.

Three areas in the state' will be considered as having loess mantled erosional topographies. One area is in the western part of the state, a second area is in the northeastern part of the state, and the third area extends from near the middle of the state to near the eastern border. These three areas are designated for convenience, the Crawford area, the Jackson area, and the Cedar area.

101Kay, G. F., and Apfel, E. T., The pre-Illinoian Pleistocene geology of Iowa: Iowa Geol. Survey, vol. 34, pp. 54-68, 68-65 1929 . 
THE CRAWFORD AREA: Crawford County gives the name to this broad bowshaped area which parallels in general the Missouri River. In its middle part the area has a width of about 40 miles; from here it narrows both north and south to the borders of the state. Parts of 19 counties are included in this area. There are gradations on the east and west into topographies which have not been included in the Crawford area except where the Sioux River is the boundary on the west, and in Ida and Carroll counties where the Iowan and Mankato dirifts form the boundary of the Crawford area.

The prevailing position of the loess in the Crawford area is on the tops of hills and on the upper parts of the slopes. Thinner loess extends into and across the valleys, giving the appearance of loess built topography, but numerous road cuts and some exposures along the valleys show clearly that the hills have cores and that the loess in the valley bottoms is thin. On the higher slopes the loess is from 10 to 30 feet or more in thickness, as illustrated by figure 45 whereas on the lower slopes the loess is in most places less than 10 feet, locally only 3 or 4 feet in thickness. The abundant loess in the upper slopes in many places has a definite relation to the drift core. The crest of the hill, due to loess deposition, has migrated to the eastward with the loess asymmetrically distributed over the drift. It is thicker on the east side than on the west side. This is a normal relationship in this region. The loess, a wind-blown material, was carried from the west, and hence the windward slopes have had deposited upon them less of the loess than was deposited on the leeward slopes. Thus, coincident with increase in relief by loess deposition the slopes were modified. The eastern slopes particularly show the effect of migration of the crests of the hills without equivalent shifts of the valley bottom. Western slopes may show slight modification or if the increase of relief by loess deposition is relatively great when compared with the drift relief, the westward slopes may be appreciably steepened, as seen in figure 46 . The hill and valley modifications are not everywhere unifom in character nor are they of the same kind. The western part of the Crawford area has more loess, and hence is more modified than the eastern part. This is as would be expected since it is nearer the Missouri River Valley, the chief source of loess supply.

The somewhat heavy loess over the Crawford area is of Peorian 


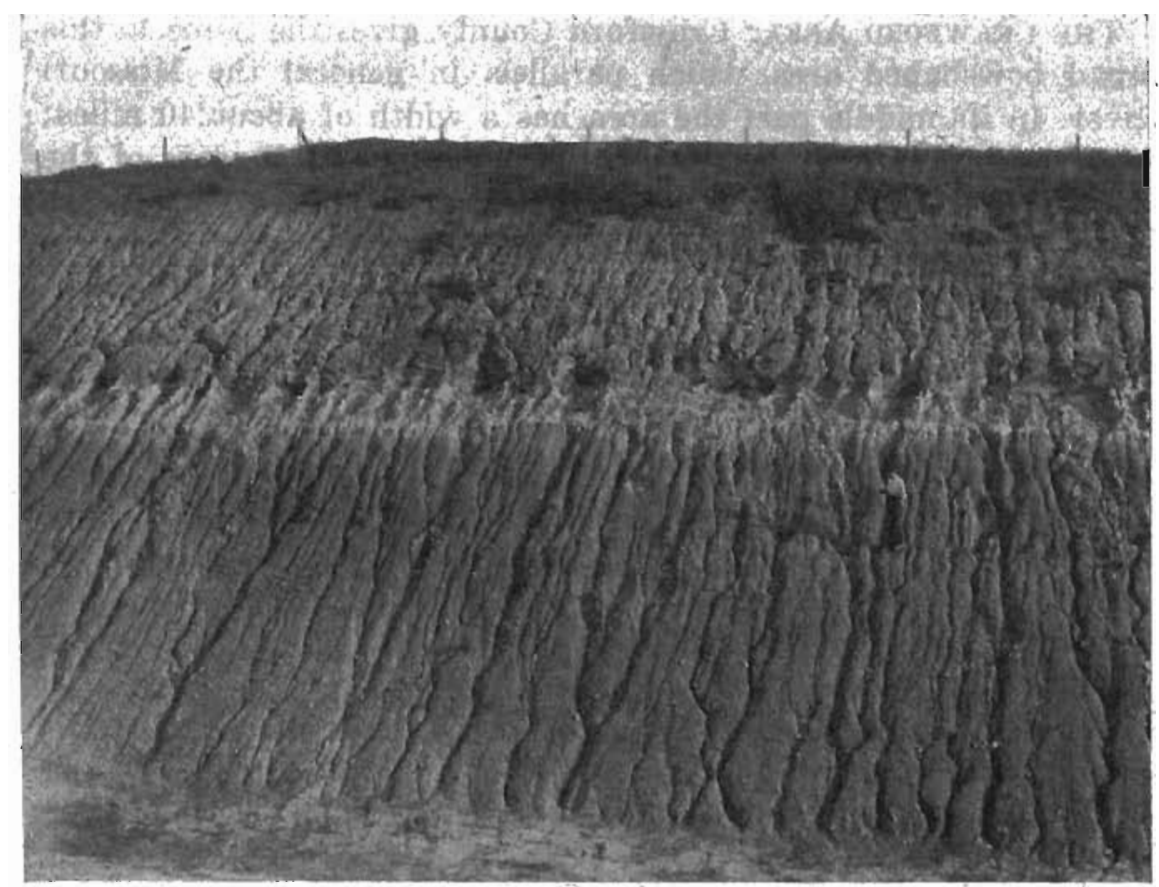

Figure 45. Divide cut between Aspinwall and Manilla, Crawford County, showing about 25 feet of Peorian loess overlying Kansan drift.

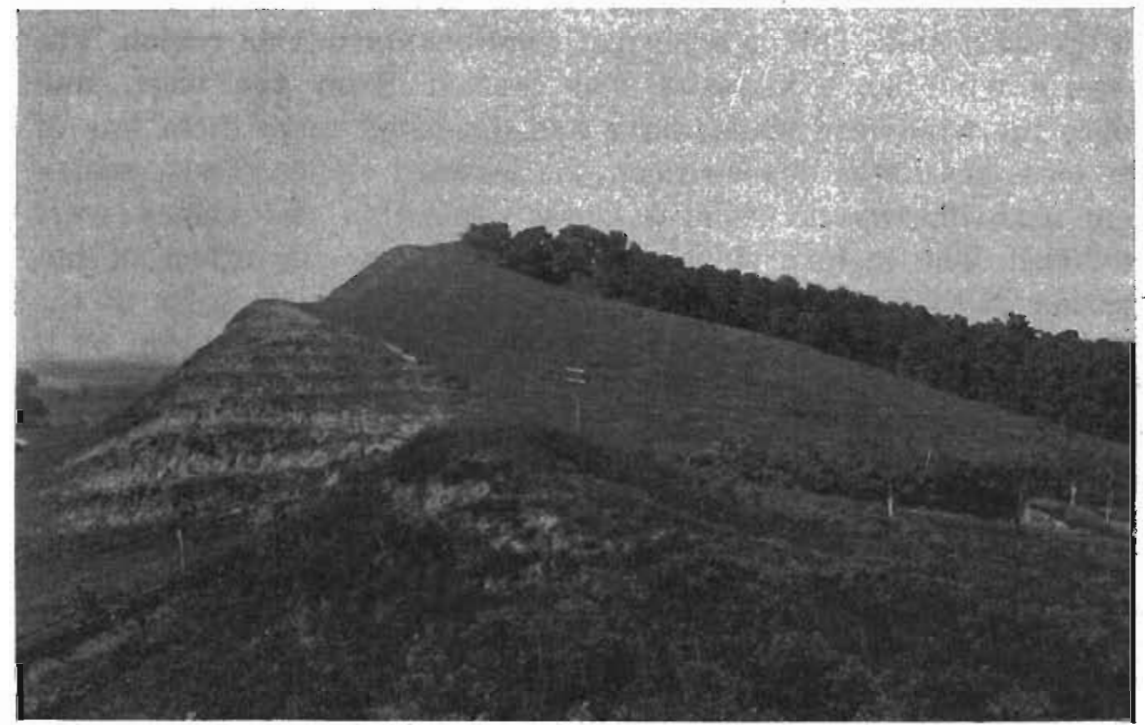

Figure 46. Looking north along loess bluffs from top of ridge south, of Pisgah, Harrison County. 
age. There are beneath this younger loess an older loess and a series of silts and sands which lie unconformably upon the eroded surface of the Kansan gumbotil plain, and which contribute in a minor way to the topographic development of the area. These older deposits, which in part at least are correlated with those known to be younger than the lllinoian, and older than the Iowan, constitute the Loveland loess and associated silts and sands.

THE CEDAR AND JACKSON AREAS: The typical loess erosional areas of northeastern Iowa are found in parts of Cedar and Jackson counties. These areas lie respectively at the south and east margins of the Iowan drift, the boundaries of which are sinuous and along which loess thickens abruptly. Where the boundaries of the loess mantled areas are over Kansan drift the loess thins gradually and hence the lines of separation of the topographies are not definite.

The reliefs of the Cedar and Jackson areas differ somewhat. The maximum relief of the Jackson area is about 400 feet, whereas the relief of the Cedar area is only half as much. The proximity of the Jackson area to the Mississippi River, and the underlying indurated rocks account for the greater relief in this area. The indurated rocks in the Cedar area have but little effect upon the topography.

The prevailing features of the Cedar and Jackson areas are loess-built structures on the hill slopes and thick loess deposits bordering the erosion carved valleys. The modifications of the erosion slopes take the form of rolling hills -dune-like accumulations of loess and sand. The total relief of the surface is increased by the presence of the loess, but the chief result has been the multiplying of slopes together with the steepening of the slopes along the river valleys. On the uplands or divides the loess is in most places thin, perhaps not more than 10 feet thick. These divide areas are gently rolling, conforming to the major slopes of the underlying erosion surface, but have their own distinctive topographic expression as seen in the variations in the convexity of the different parts of the slope and in the minor surface irregularities.

Near the main stream courses the loess is thicker than on the divides, in many places reaching a thickness of 30 or 40 feet or even more. Here the underlying erosional drift topography has been distinctly modified. Slopes east of the valleys have under- 
gone greatest modification, indicating the effect of the prevailing westerly winds. The crests of the hills along the valleys are capped asymmetrically by loess-thickest on the eastern leeward slopes. The hill slopes are broken into a series of undulating convex and concave curves. The shoulders of the hills are rounded by loess 'with accompanying steepening of the lower slopes.

\section{Loess Depositional Topography}

A narrow strip 3 to 20 miles in width bordering the flood plain of Missouri River has loess depositional topography. The area includes parts of Woodbury, Monona, Harrison, Pottawattamie, Mills, and Fremont Counties. To the west is the Missouri flood plain; to the east is the loess mantled erosional topography of the Crawford area already described.

The area of loess depositional topography has a greater thickness of loess than the area of loess mantled erosional topography. Here, a considerable part of the relief is in loess, as a thickness of 90 feet has been measured above the level of the Kansan gumbotil (fig. 47), and thicknesses somewhat greater have been reported by well drillers.

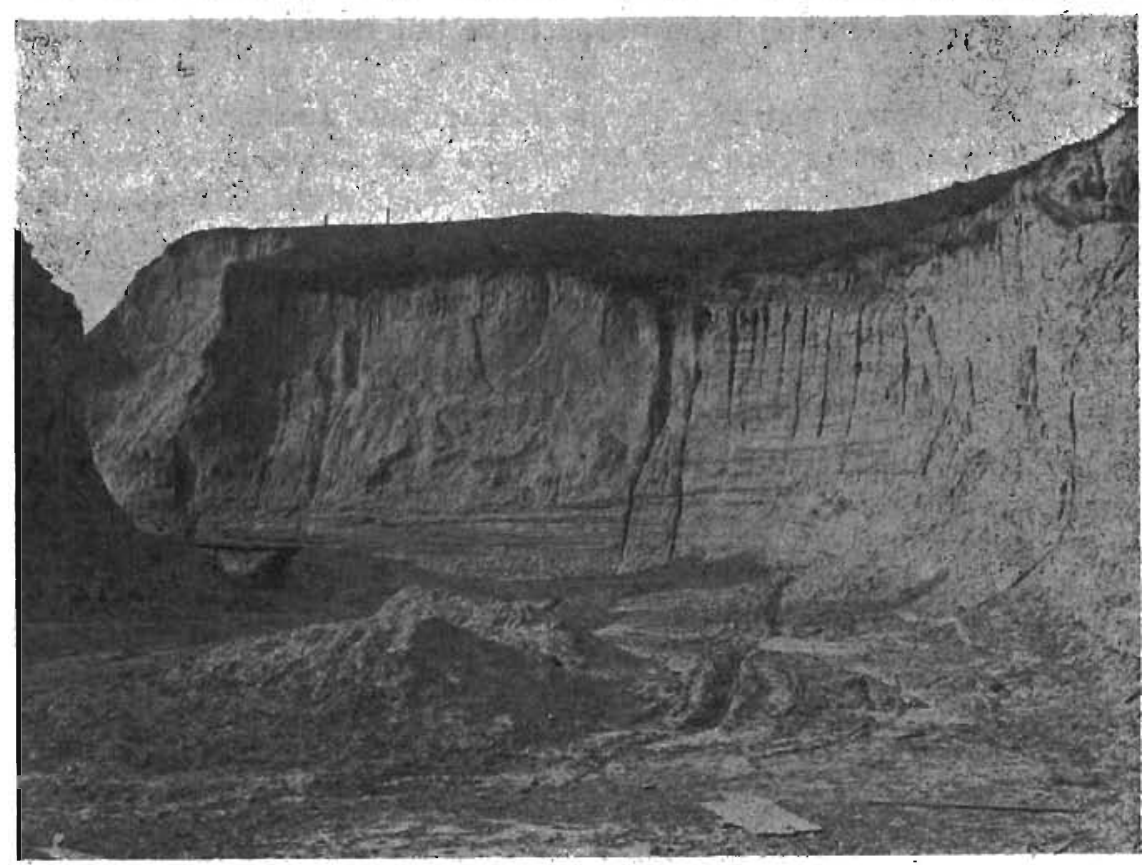

Figure 47. Cut showing 90 feet of Peorian loess, near Missouri Valley, Harrison County. 
The characteristic features of the thick loess area are the apparent lack of system in the divides, the sharp hills with stepped slopes, and steep valley walls in many places cut by gullies. The relief is more than 200 feet within distances of a few miles. The area is very rough for a region of such moderate relief.

The interstream areas do not rise by successive elevations to the divides but present a series of irregular, broken, north and south ridges which face the west and are interrupted at each streamway. Figure 48 illustrates this north-south trend of the loess ridges just east of the Missouri River Valley. The prevailing westerly winds which carried the loess chiefly from the Missouri River flat have been the controlling factor in the distribution and development of the loess topography.

The hills which separate the waterways are in many places narrow-crested and steep-sided and have a series of small terraces or steps called "cat-steps" on the more abrupt slopes. These "cat-steps" are the result probably of slipping or faulting along the characteristic vertical joint planes of the loess.

The thick loess area is well drained.' It lies across the lower parts of the westward flowing tributaries of Missouri River, whose heads are beyond the thick loess. The larger streams have relatively broad flood plains on which the streams meander in short turns. The margins of the valleys are sharply marked by steep slopes and the characteristic hills of the area. These hills readily develop gullies with vertical sides. In no other unconsolidated materials are like features developed to such an extent. Lateral stream erosion is fairly rapid but vertical down cutting of the streams is slow.

\section{Typical Sections of the Peorian Loess in Iowa}

With the exception of the area of the Mankato lobe of the Wisconsin glacier, loess of Peorian age is in the upper part of nearly every Pleistocene section in the state. The sections which are given here are presented because they seem to be typical of the many hundreds of similar loess sections that are available over the state, or because they present some unusual feature of thickness, fossil content, or drift relationship: Every highway, every railroad, every stream and river valley of Iowa has exposed the compact, vertical-standing Peorian loess. Being, exposed at the surface, easily cut in excavations and distinctive in color and texture, this deposit is of widespread interest. 


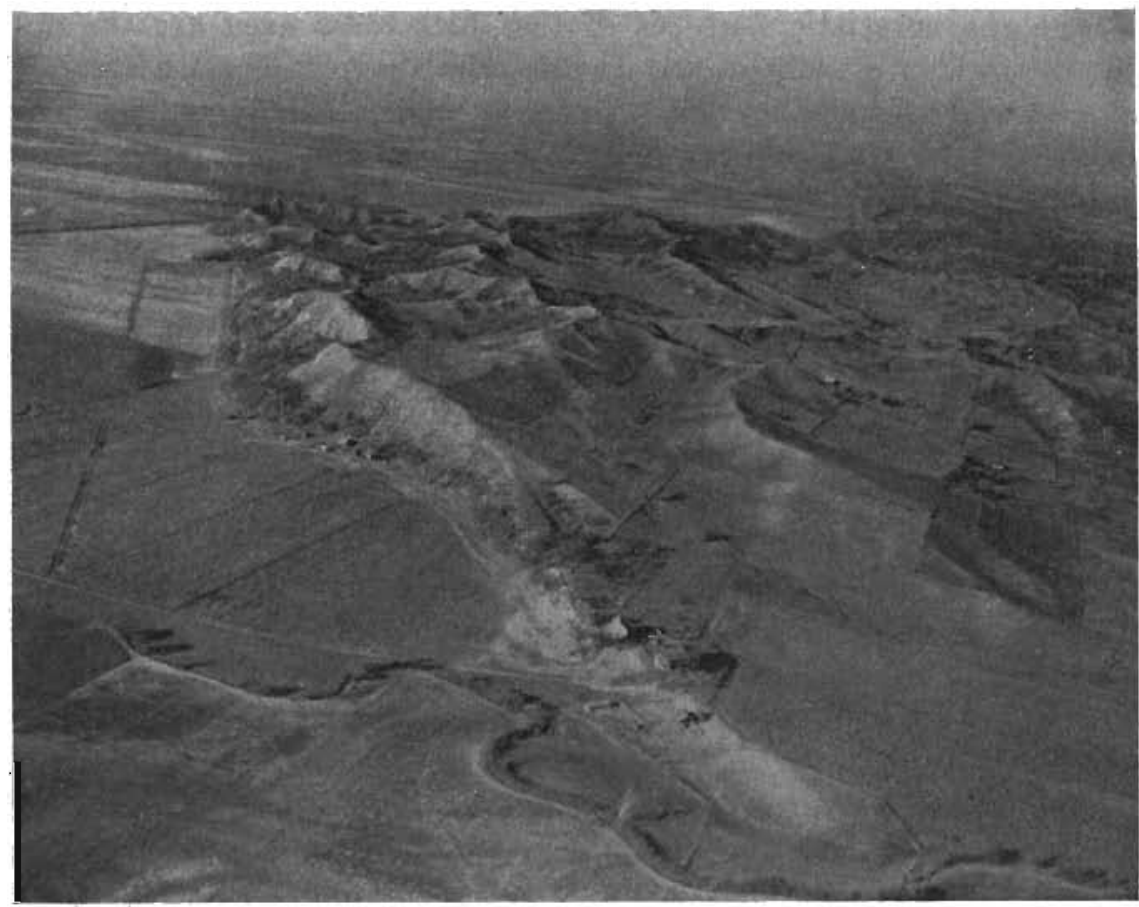

Figure 48. Airplane view of north-south trending loess ridges on the Iowa side of the Missouri River Valley. (Photo by Des Moines Register-Tribune).

In Johnson County the North Liberty lobe of the Iowan drift extends from the northeast corner of the county to 1 mile southeast of North Liberty. Since the melting of the ice of Iowan age the Iowa River has developed its course across the North Liberty lobe from west to east and forms a broad sandy flood plain which blends gradually into the southern portion of the drift plain. This thin drift containing characteristic large Iowan boulders occupies a low plain bordered by loess hills underlain by Kansan drift. As this area is' somewhat typical of the conditions at the margin of the Iowan drift in eastern Iowa a section was taken $1 \frac{1}{2}$ miles north of North Liberty in the SW $1 / 4 \mathrm{NE}^{1 / 4}$ sec. 1, Penn Township, (T.80 N., R. 7 W.), Johnson County, in one of the hills bordering the margin of the Iowan drift plain (fig. 49). Here 52 feet in all, 18 feet exposed and 34 feet in a boring, were studied. Although the base of the loess was not reached in this section, another boring farther down the hill showed the loess to be on Kansan drift.

The loess is yellow and very irregular in mechanical composi- 


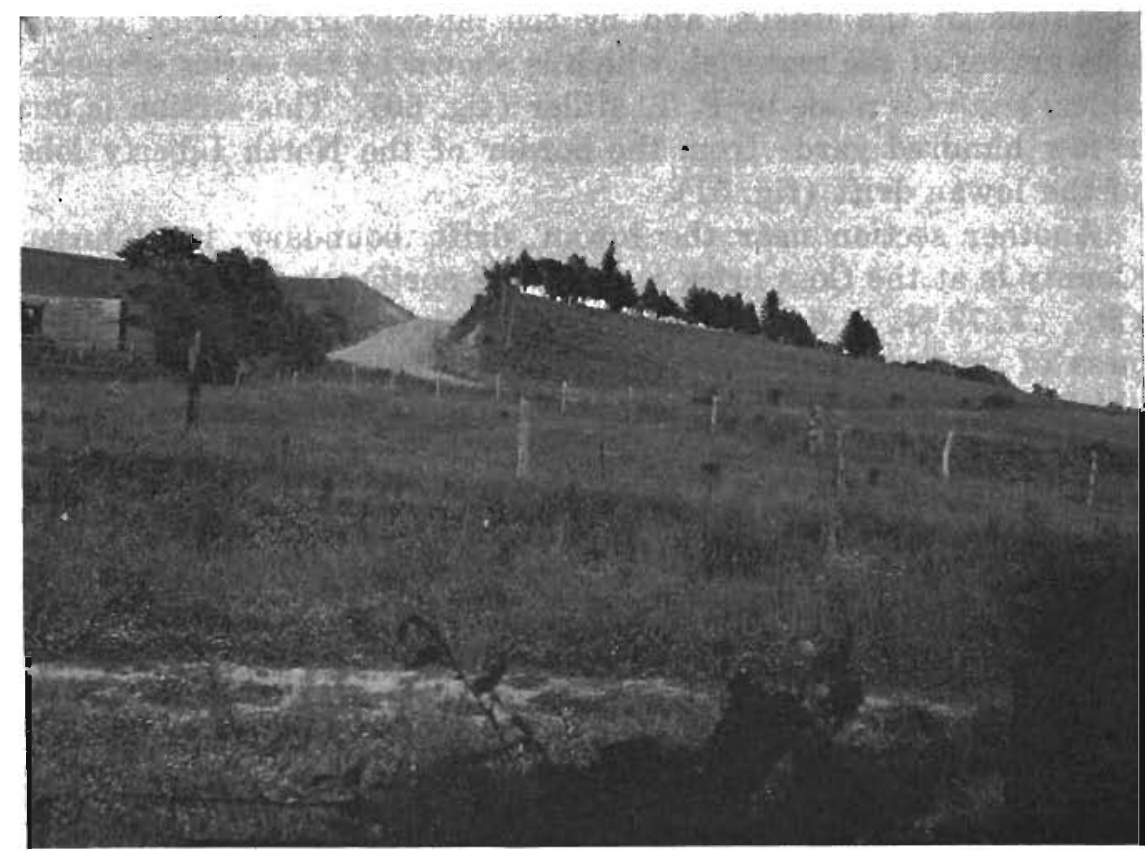

Figure 49. Loess hill bordering the Iowan drift plain near North Liberty, Johnson County. A 52-fuot loess section was obtained here.

tion. With the exception of the upper 5 feet, all is calcareous and contains many limy concretions which have been formed about the roots of plants.

The section is fossiliferous except for the 5 feet at the top. The section is as follows:

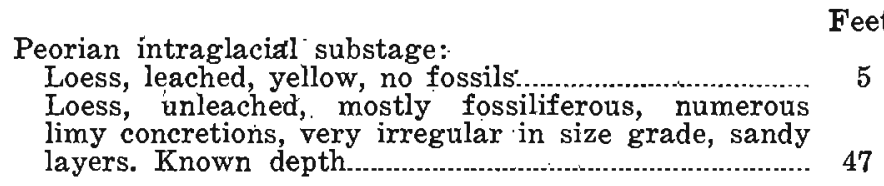

A detailed study of the fossil mollusks collected from the loess of this section has been made by Cameron. ${ }^{102}$. This study indicates a damp, woodland environment during deposition of the basal loess, with a gradual change to $a$ dryer climate and a more open type of vegetation during accumulation of the upper loess. The loess is thought to have been blown in relatively quickly, this rapid deposition being reflected in the scattered vertical repre-

${ }^{102}$ Cameron, Cornelia. Comparative study of the fossils of two loess sections in Iowa: Thesis, Dept. of Geology, State Univ, of Iowa, 1985. 
sentation of the fossils, and by the notable irregularity of the size grades of the material, which is shown by the series of mechanical analyses made by P. T. Miller (fig. 50). This section is but a few hundred yards from the border of the North Liberty lobe of the Iowan drift (fig. 51).

Another section near the Iowan drift boundary in Johnson County is at the Goss brick yard in the northeastern part of Iowa City, (T. 79 N., R. 6 W.). Here the loess is known to have a thickness of more than 30 feet, but recently only about half of this thickness has been free from wash and slumping, and available for study. The section shows:

Peorian intraglacial substage:

Feet Inches

Loess, leached, yellow with several undulating, horizontal, ferruginous bands. No fossils:

Loess, unleached, bluish gray, streaked with red due to oxidation of the vertical and horizontal root tubules; highly fossiliferous. Exposed.

This section is interpreted by Cameron as representing an area of slower loess accumulation and more even conditions of

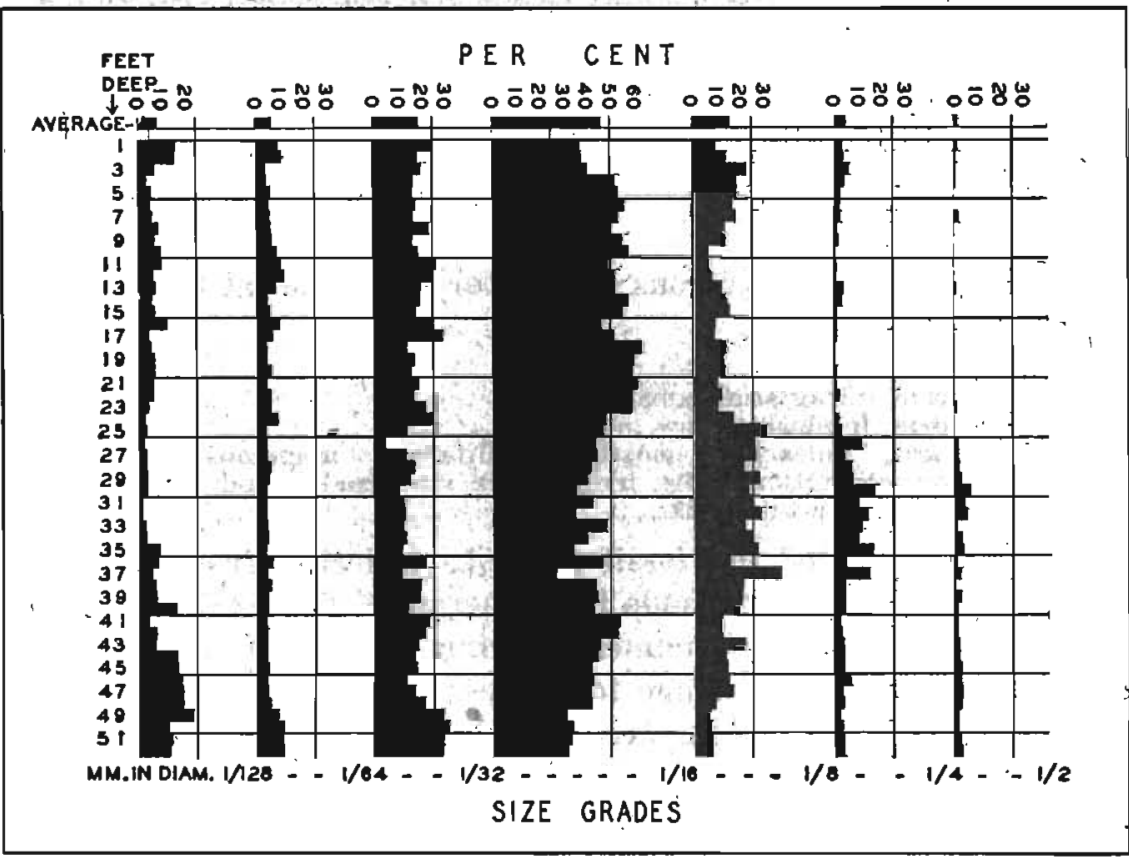

Figure 60. Graph showing a series' of mechanical analyses of a loess section near North Liberty, Johnson County. Samples taken 2 feet apart vertically. 


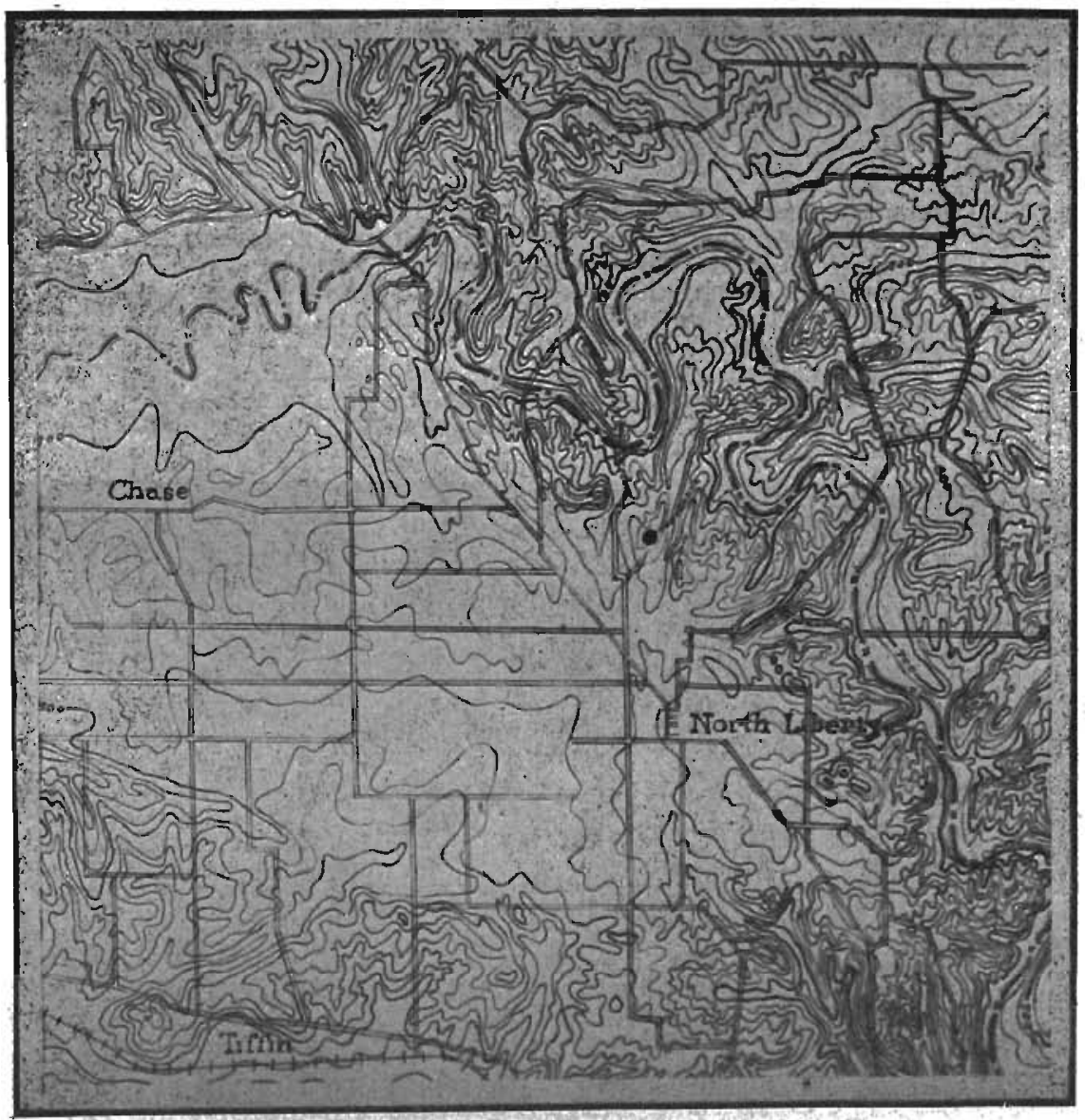

Figure 51. Topographic map of the North Liberty area showing the location of the 52-foot loess section.

climate and vegetation than the North Liberty section. The loess is more indicative of a continued damp, well-forested environment. In the Gaulocher pit which adjoins the Goss pit, contact of the yellow and gray phases of the loess is sharp, and the effect of oxidation of the plant roots is strikingly apparent (fig. 52).

A very unusual Peorian section occurs in the $\mathrm{NE}^{1 / 4}$ sec. 15, Franklin Township, (T. 80 N., ${ }^{9}$ R. 22 W.), Polk County; in a cut through the top of a hill along the northeast valley wall of the Skunk River. This cut lies about 6 . miles north of Mitchellville and is known as the Mitchellville cut. The hill is locally known as Lookout Mountain, the top of which stands 240 feet above the 
level of the river. A cut 38 feet deep was made in the recent construction of State highway 64 (formerly 88), and additional boring to a depth of 25 feet gave a vertical section of 63 feet. The section shows:

Mankato glacial substage:

Feet Inches

Till, coating the top of the hill, contains a large amount of loess. The irregular contact between the till and the underlying loess was developed by glacial plowing. Average thickness of the till.

Peorian intraglacial substage:

Loess, oxidized and leached.

Loess, oxidized and unleached.

Loess, unoxidized and unleached

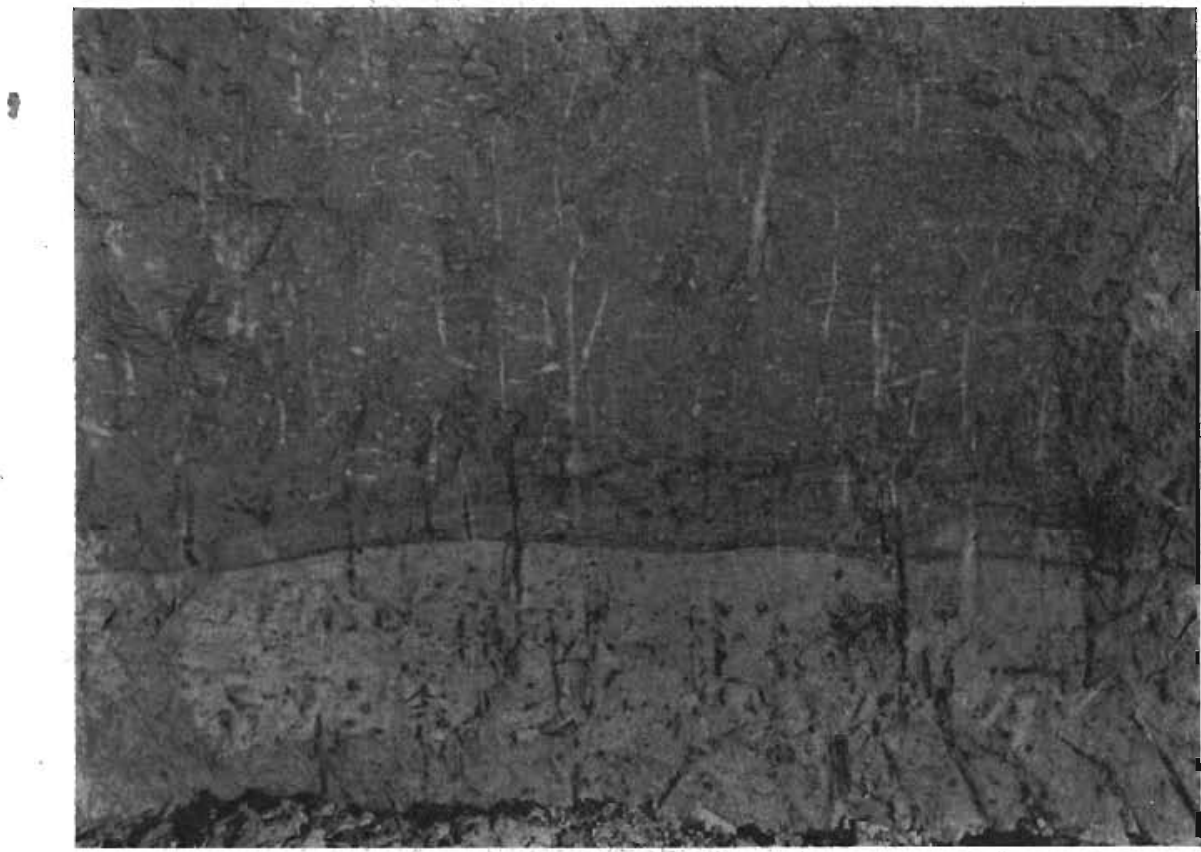

Figure 52. View in the Gaulocher clay pit, Iowa City, Johnson County, showing two phases of loess and effect of plant roots in oxidation and deoxidation.

Within the loess part of the section there is much woody material, with logs several feet in length showing little replacement or alteration, though some specimens show considerable disintegration. The unleached loess is highly fossiliferous and it is clear that the plant life and the animal life represented here were living at the same time and in the same environment. A detailed study of the fossil invertebrates from this cut was made by Cameron. The 
loess was found to be fossiliferous throughout. The snails are predominently of the woodland type, only one of 16 species of gastropods identified belonged to a water environment, this form being a fresh water pulmonate. A complete discussion of the invertebrate fauna of this section is given on page 194 .

The vegetal material from this section requires further paleobotanical study, but a log at Iowa City collected from this section has been identified as yew, and spruce and hemlock have been identified by Cameron. Indications point to a coniferous forest living in a climate not immoderately cold, supporting a woodland snail fauna on its floor.

Just west of Panora, Guthrie County, in the middle of the north line of sec. 6, Cass Township, (T. 80 N., R. 30 W.), is another fine cut showing Peorian loess overlain by Mankato drift. It' is on the west slope of the Raccoon River. The section is as follows:

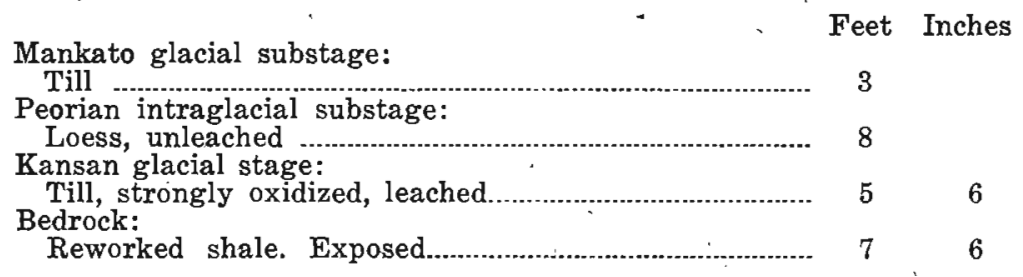

These relationships are photographically shown in figure 53 .

A section showing a humus accumulation on the Peorian is found along the east-west road just west of the adjoining corners of secs. 8, 9, 16 and 17, Lincoln Township, (T. 79 N., R. 4 E.), Scott County. Here the section is:

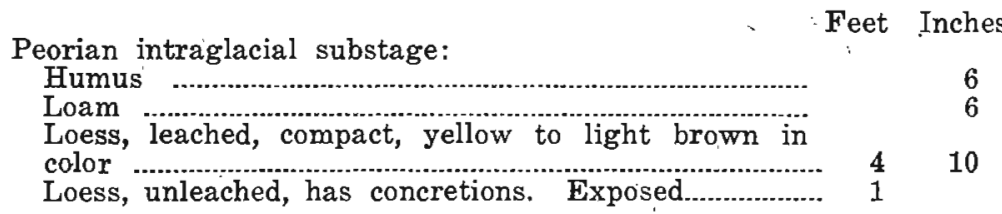

This section is on the lllinoian upland and is characteristic of the normal amount of leaching which has occurred in this area when no erosion has taken place.

Leached Peorian loess has been used in the manufacture of clay and pottery products. A good section of leached Peorian loess is shown in the Keota Brick and Tile Co. pit, in the southeastern part of Keota, Keokuk County, in the NE $1 / 4$ sec. 25, Lafayette Township, (T. 76 N., R. 10 W.). 


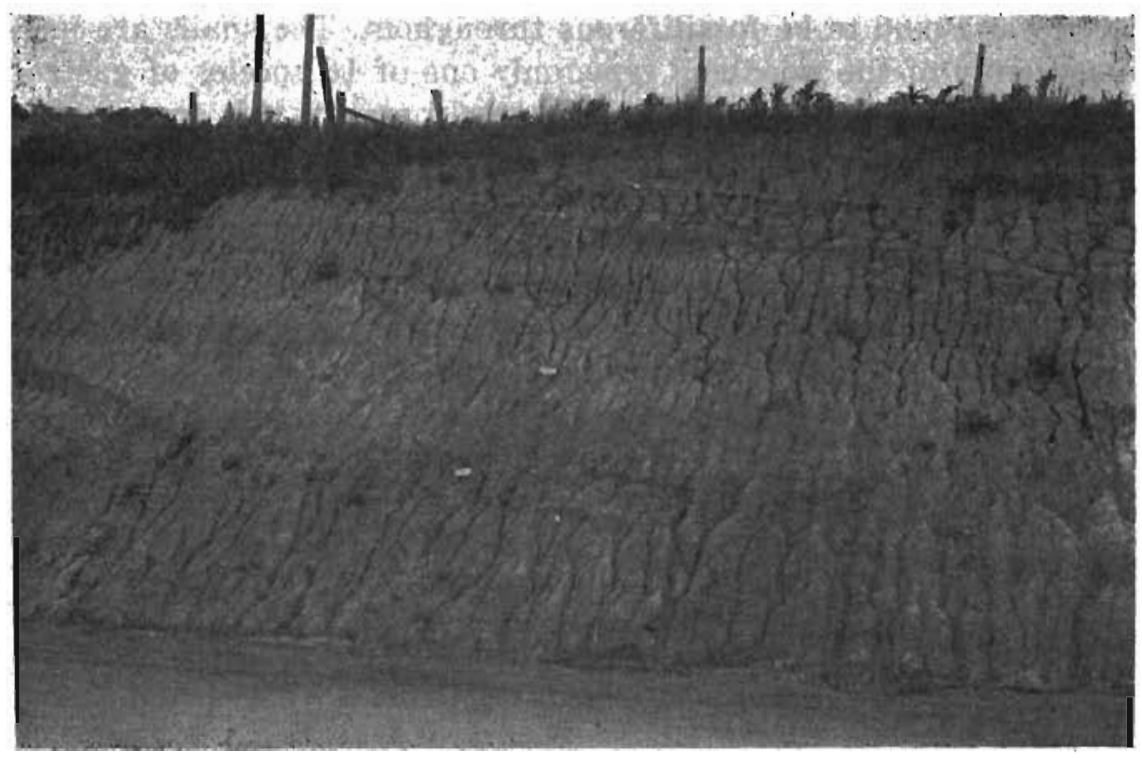

Figure 53. Pearian loess overlain by Mankato drift, just west of Panora, Guthrie County.

$$
\begin{aligned}
& \text { Peorian intraglacial substage: } \\
& \text { Soil zone, dark to almost black, somewhat mealy clay } \\
& \text { Loess, leached, gray to faint yellowish clay with } \\
& \text { numerous root fibers; when dry breaks into irregu- } \\
& \text { larly shaped masses, when wet cuts with a smooth } \\
& \text { surface. Upper part seen as polygonal columns........... }
\end{aligned}
$$

Feet Inches

2

6

One hundred feet farther north in the pit is a section showing only 5 feet of leached loess, below which is a distinctly gray unleached loess filled with concretions and shells, exposed for 3 feet. The pit is at the upland level.

Great thicknesses of Peorian loess are exposed in many of the bluffs and road cuts through the hills bordering Missouri River Valley along the western boundary of the state. Just southeast of Council Bluffs, in Pottawattamie County, the loess can be seen in high bluffs, the thickness ranging up to 100 feet.

\section{Characteristics of the Peorian Loess}

\section{General Characteristics}

Peorian loess is light-yellow and gray in color and shows essentially no stratification. Its particles are angular and are evidently the result of rock abrasion, grinding and impact. Their diameters range from $1 / 2$ millimeter to $1 / 256$ millimeter, but the 
greatest percentage falls in the size grade $1 / 8$ millimeter to $1 / 64$ millimeter. Quartz is by far the most common mineral. Other constituents are feldspar, muscovite, glauconite, pyrite, magnetite, ilmenite, hornblende, pargasite, glaucophane, actinolite, tremolite, hypersthene, enstatite, augite, aegerite-augite, aegerite, chlorite, andalusite, epidote, zircon, garnet, tourmaline, titanite, biotite, staurolite, topaz, kyanite, rutile, brookite, barite, monazite, riebeckite, basaltic hornblende, and anthophyllite.

Chemically, the Peorian loess of Iowa contains $\mathrm{SiO}_{2}, \mathrm{TiO}_{2}$, $\mathrm{MgO}, \mathrm{CaO}, \mathrm{Na}_{2} \mathrm{O}, \mathrm{K}_{2} \mathrm{O}, \mathrm{Al}_{2} \mathrm{O}_{3}, \mathrm{Fe}_{2} \mathrm{O}_{3}$. $\mathrm{FeO}, \mathrm{MnO}, \mathrm{P}_{2} \mathrm{O}_{5}, \mathrm{H}_{2} \mathrm{O}, \mathrm{CO}_{2}$, $\mathrm{ZrO}_{2}, \mathrm{~S}, \mathrm{Cr}_{2} \mathrm{O}_{3}$, and $\mathrm{BaO}$. Where the loess has been exposed to chemical weathering over a sufficient time, the calcium carbonate has been leached out.

Curiously shaped calcareous concretions known as loess kindchens 'and pipestems, deposits of calcium carbonate about plant roots, are found in many places in the loess. The fossils with few exceptions are of land origin and in large part consist of land gastropods.

A characteristic feature of the loess is its ability to stand in vertical cliffs (fig. 54). Striking examples of this feature may be seen along Missouri River where the loess ranges in thickness up to 100 feet. It has been suggested that this is due to the angularity of the composing' particles, and to buttressing by rods and tubes which have been formed about the plant roots and stems. The loess was laid down over and about them and calcium carbonate was later deposited. The loess is distributed generally but not uniformly over the uplands where it forms a more or less irregular veneer and is thickest at the tops of the more prominent ridges. In fact, the greater prominence of these ridges is due in large part to the accumulated loess. It is significant that the deposit is absent from alluvial flats and frequently from the bases of bluffs.

In thickness, the loess ranges from zero to about 100 feet, but if it were spread evenly over the entire surface of the state it would form a deposit about 10 feet thick.

\section{Mechanical Analyses}

Series of Peorian loess samples collected from various parts of the state have been analyzed in the laboratory by P. T. Miller. The samples were collected along field traverses so that the relationship of size of particles to distance from the probable source 


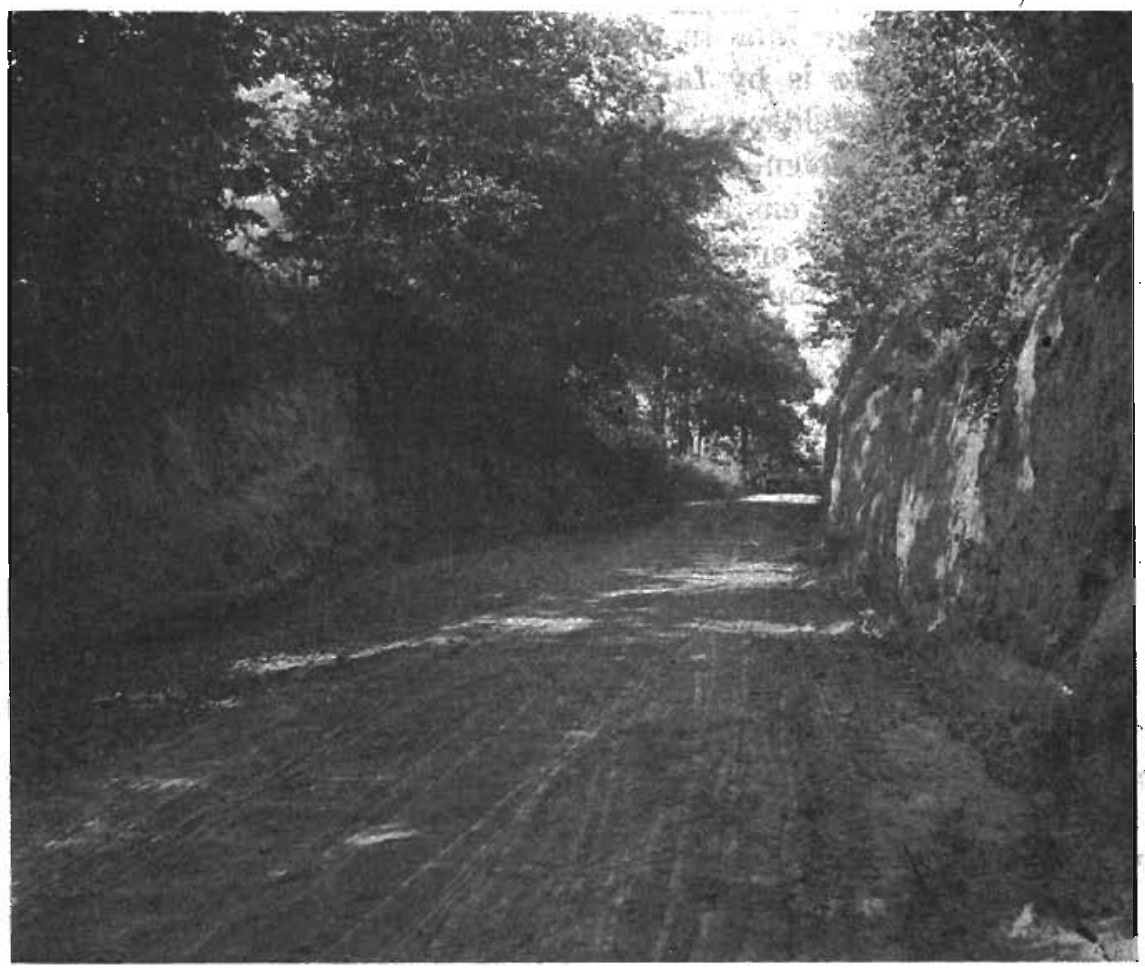

Figure 54. Vertical walls in a Peorian loess cut near Magnolia, Harrison County.

might be ascertained. The traverses along which the samples were collected are shown on the map of Iowa in figure 55.

In northwestern Iowa two series of samples were collected. One was between Sioux City and the Wisconsin drift border near Sac City and the other was between Sioux City and Spencer. The analyses of samples between Sioux City and Spencer (fig. 56), show no change in texture from west to east. The section between Sioux City and Sac City (fig. 57), shows that the loess becomes slightly finer toward the east.

In southern Iowa samples were collected 'between Donnellson and Sidney. They show that the loess is of about equal texture from Lee County west to Decatur County. From Decatur County to Taylor County the thin loess is slightly-finer. From Taylor County to the Missouri River the loess becomes slightly coarser in texture (fig. 58).

In the section between Tama and Iowa Falls (fig. 59), all on 


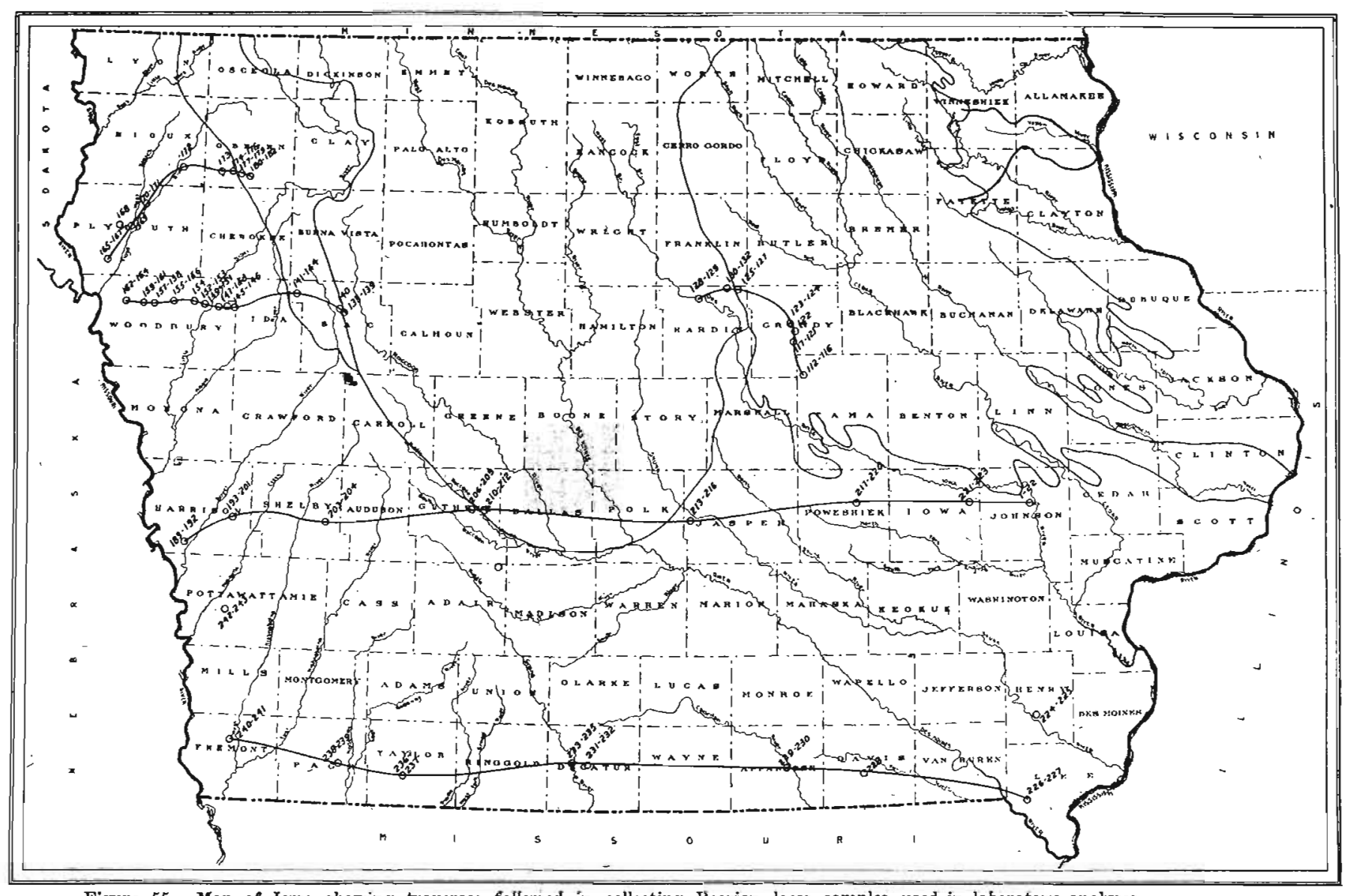

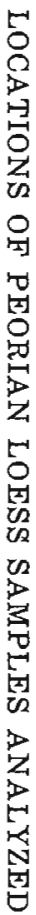

Figure 55. Map of Iowa showing traverses followed in collecting Peorian loess samples used in laboratory analyses 
the Iowan drift surface, the texture of the loess varies within cuts and local areas. There is no general variation between these two places. The section across Iowa from Missouri Valley to Iowa City (fig. 60), shows the loess becoming slightly finer from the Missouri River east across Shelby and Guthrie Counties. However, farther east in Poweshiek and Iowa Counties it is coarser and at Iowa City it is finer, about the same as in Guthrie County.

Samples of Peorian loess between the Fowan drift border in northeastern Iowa and the Mississippi River were collected for laboratory analysis. Samples were collected at a depth of 4 feet as well as at a depth of 7 feet. One set of samples was collected along a traverse from Ridgeway in Winneshiek County to McGregor, along the Mississippi River, in Clayton County. Eighteen samples were collected at a depth of 4 feet, and 11 samples were collected at a depth of 7 feet.

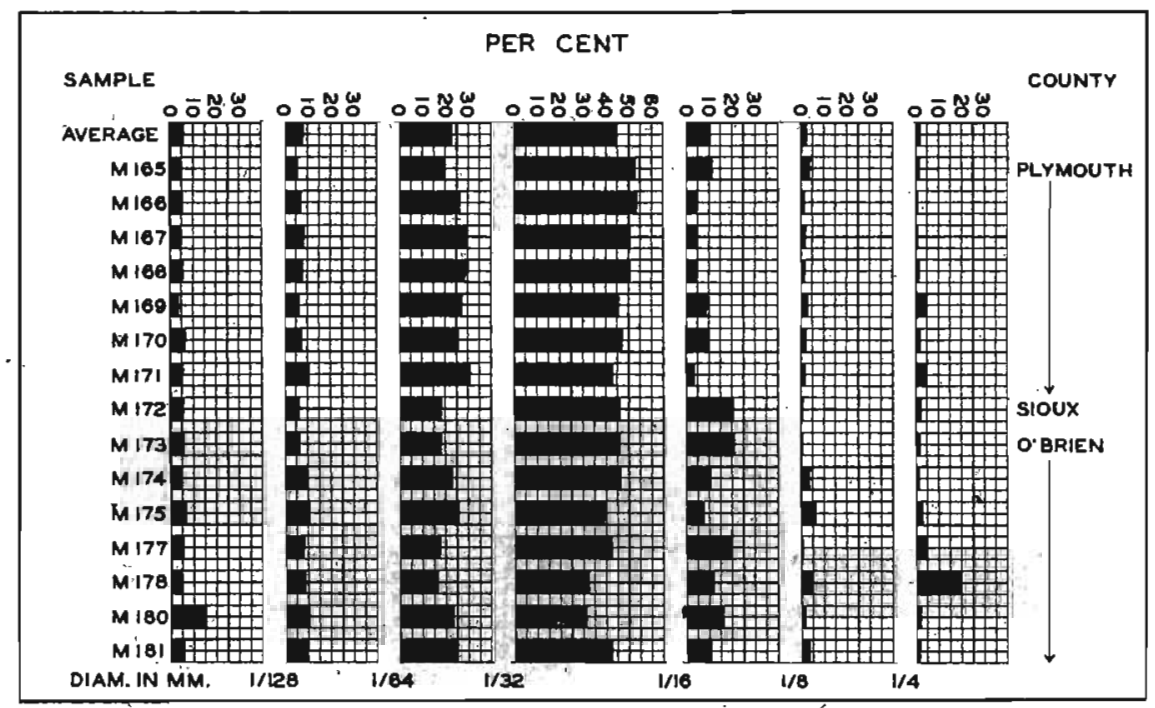

Flgure 56. Graph showing the series of mechanical analyses of loess samples collected

The second traverse was made from West Union. in Fayette County to McGregor in Clayton County. Twenty-two samples from the 4-foot depth were collected and 17 samples from the 7foot depth. The averages of these suites of samples are given in figures 61 and 62. Figure 63 shows the average mechanical analysis percentages for loess samples collected throughout the state. 


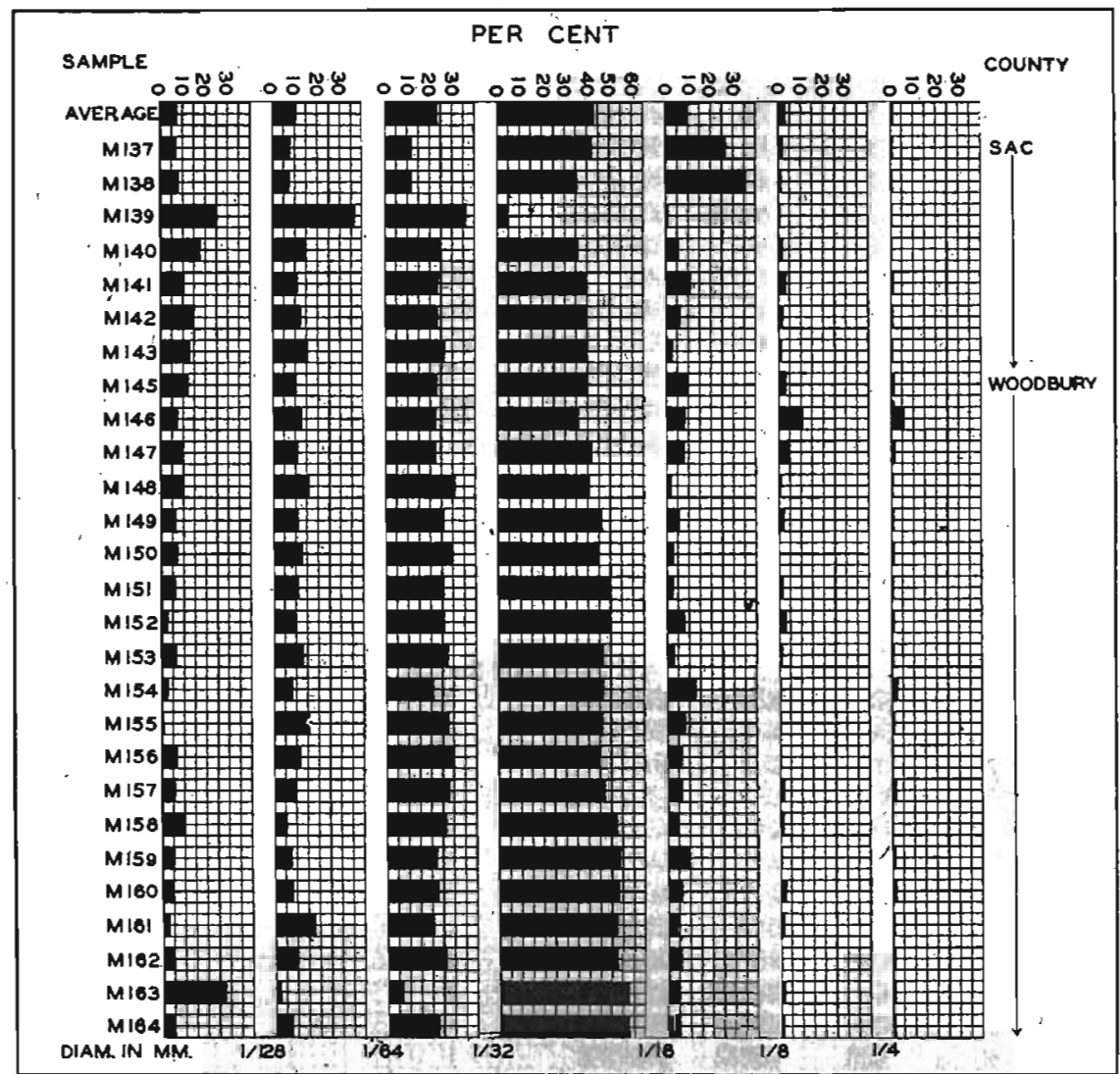

Figure 57. Graph showing the series of mechanical analyses of loess samples collected between Sioux City and Sac City.

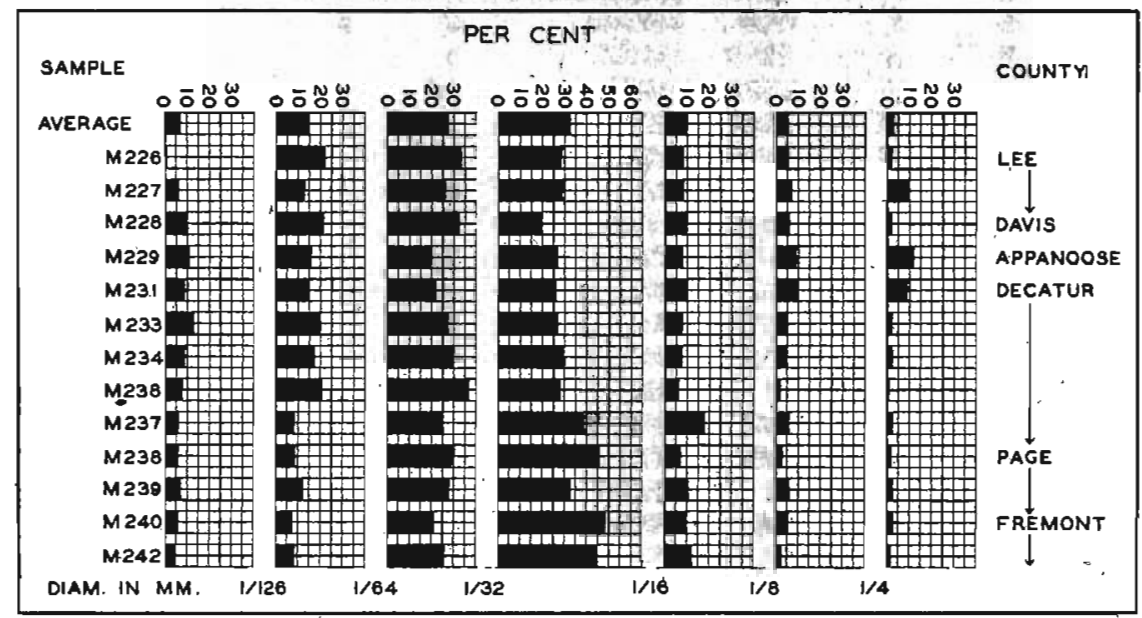

Figure 58. Graph showing the series of mechanical analyses of loess samples colleoted between Donnellson and Sidney. 


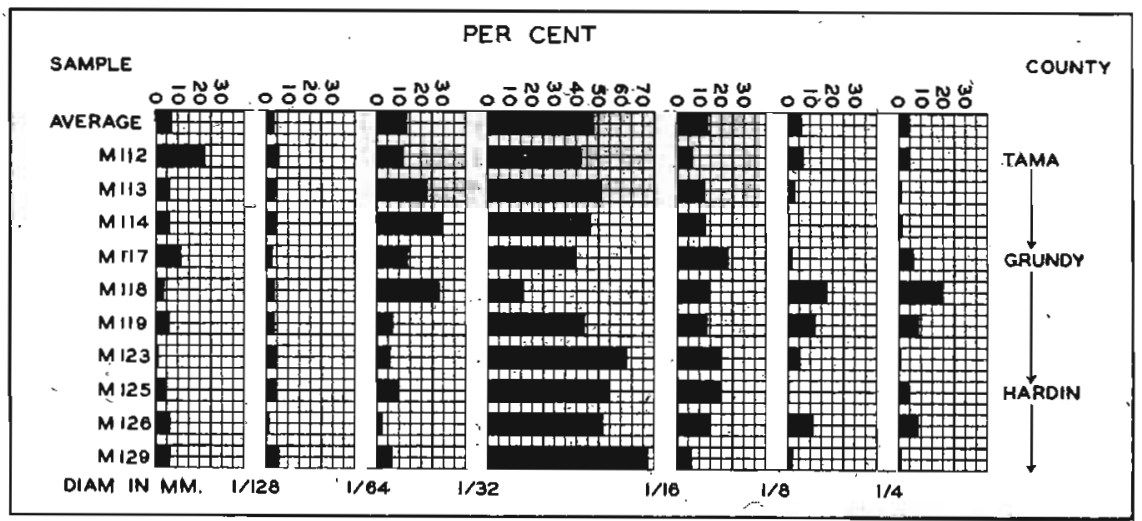

Figure 59. Graph showing the series of mechanical analyses of loess samples collected between Tama and Iowa Falls.

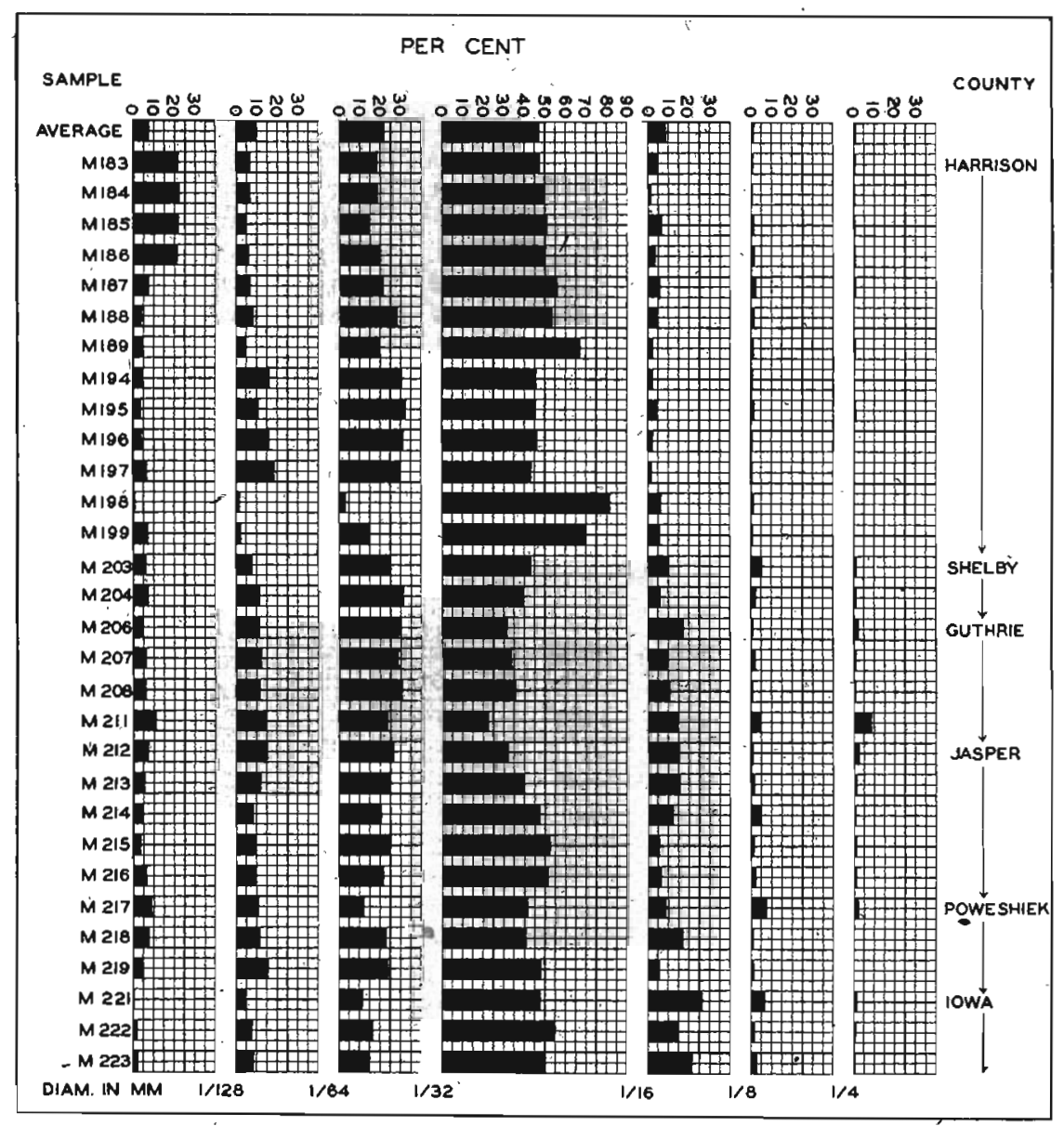

Figure 60. Graph showing the series of mechanical analyses of loess samples collected between Missouri Valley and Iowa City. 


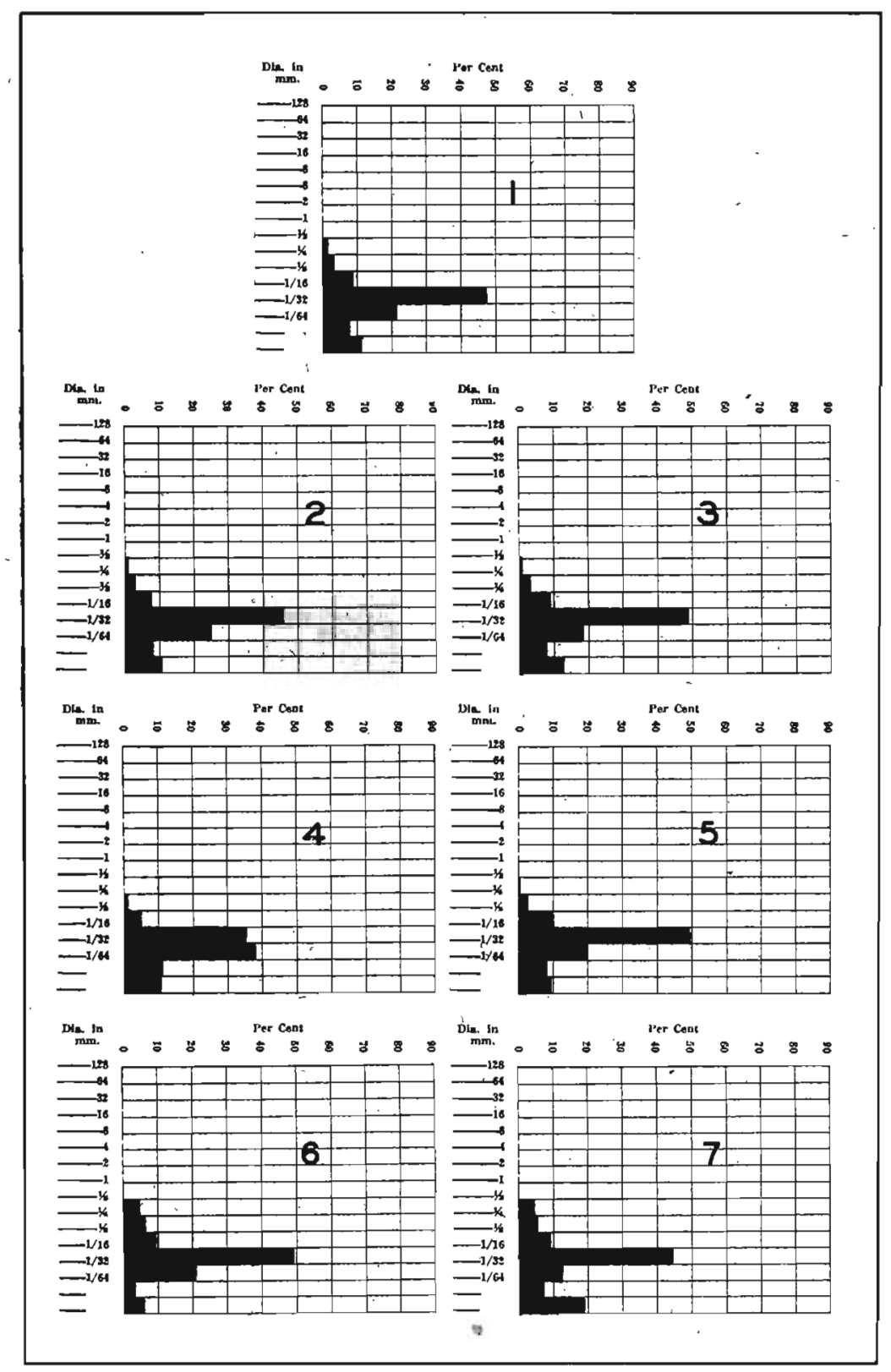

No. 1. Average of 40 samples of Peorian loess taken from 4 feet deep, between the Iowan No drift border and the Mississippi River

No. 2. Average of 22 samples taken from 4 feet deep hetween McGregor and West Union.

No. 3. Average of 18 samples taken from 4 feet deep between McGregor and Ridgeway.

No. 4. Average of 4 samples taken from 4 feet deep southwest of McGregor.

No. 5. Average of 4 samples taken from 4 feet deep northwest of MeGregor.

No. 6. Average of 4 samples taken from 4 feet deep near Iowan drift border near West Union.

No. 7. Average of 4 samples taken from 4 feet deep near Iowan drift border near Ridgeway. Fisure 61. Graphs showing mechanical analyses of Peorian loess collected in northeastern

$$
\text { Iowa. }
$$



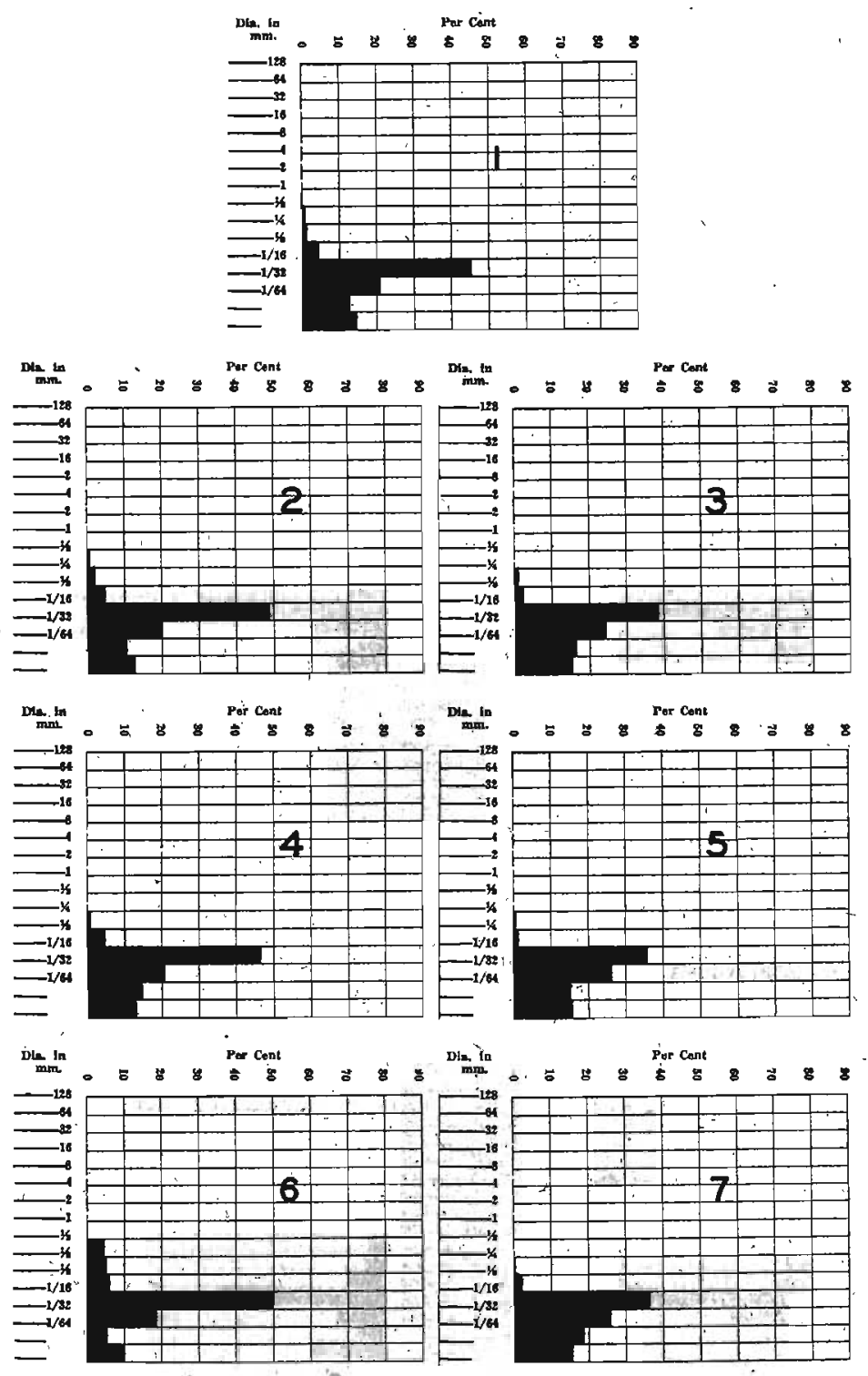

No. 1. Average of 40 samples of Peorian loess taken from 7 feet deep, between the Iowan drift border and the Mississippi River.

No. 2. Average of 22 samples taken from 7 feet deep between McGregor and West Union.

No. 2. Average of 22 samples taken from 7 feet deep between McGregor and West Union.

No. 4. Average of 4 samples taken from 7 feet deep southwest of McGregor.

No. 5. Average of 4 . samples taken from 7 feet deep northwest of. McGregor.
No. 6. Average of 4 samples taken from 7 feet deep near Iowan drift border near West Union.

No. 7. Average of 4 samples taken from 7 feet deep near Iowan drift border near Ridgeway.

Figure 62. Graphs showing mechanical analyses of Peorian loess collected in northeastern Iowa. 
A number of conclusions may be drawn from the study of the mechanical analyses of Peorian loess. There are distinct variations in the loess within single cuts and local areas. These are more distinct in the analyses than the general variations from one part of the state to another.

As shown in the reference to each section studied, there are slight general changes from place to place.

The Missouri River loess becomes finer with increase in distance east of the Missouri River. Likewise, the loess becomes finer in northeastern Iowa with increasing distance from the Iowan drift border. In certain areas within the state such as Marshall, Poweshiek, and Iowa Counties the loess is as coarse as in any part of the state. Farther' south in Davis, Appanoose and surrounding counties the texture is as fine as in any part of the state.

The most logical reason for this difference in texture is the source of material and direction of transportation. Much of the loess along the Missouri River comes, no doubt, from the Missouri River flats and was transported eastward. This would give a general thinning toward the east as well as a decrease in the coarser material.

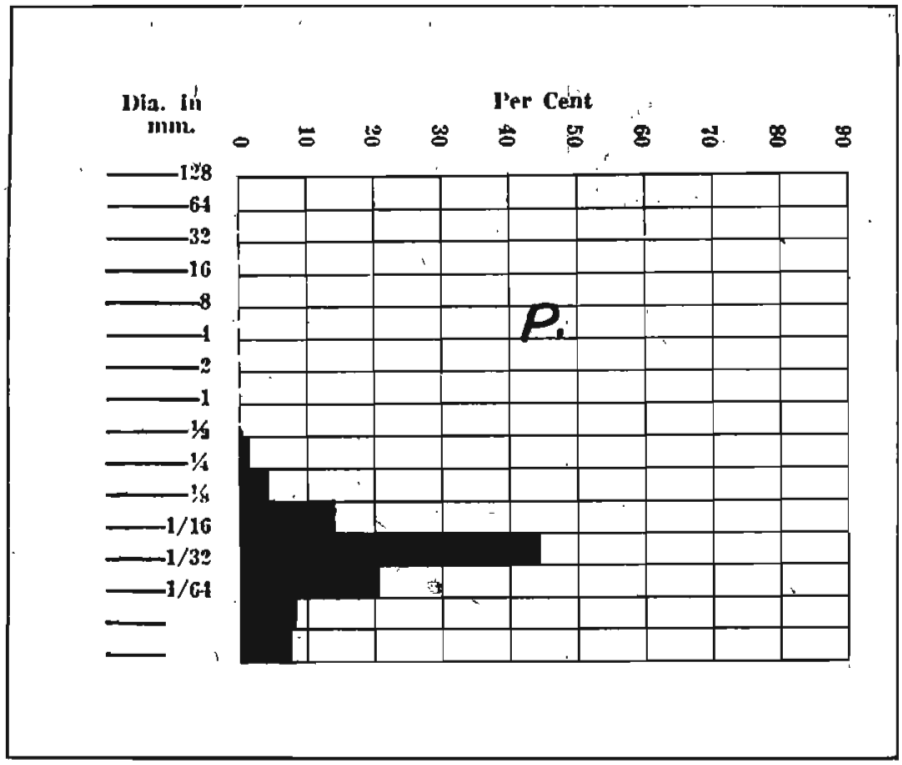

Figure 63. Graph showing the average mechanical analysis for Peorian loess samples collected throughout Iowa. 
Central Iowa received a considerable supply from the valleys carrying-drainage from the Iowan drift and consequently would be of coarser texture. In south-central Iowa, the supply of water and also the supply of loess would be less, as few of the streams head up within the Iowan drift. Also, with increase in distance from the Iowan drift the stream load would be increasingly finer.

In northeastern Iowa the series of samples collected between McGregor and the Iowan drift border just west of West Union and between McGregor and the Iowan drift border east of Ridgeway show two things: (1) A variation in texture between samples collected only a short distance apart, and (2) the average texture

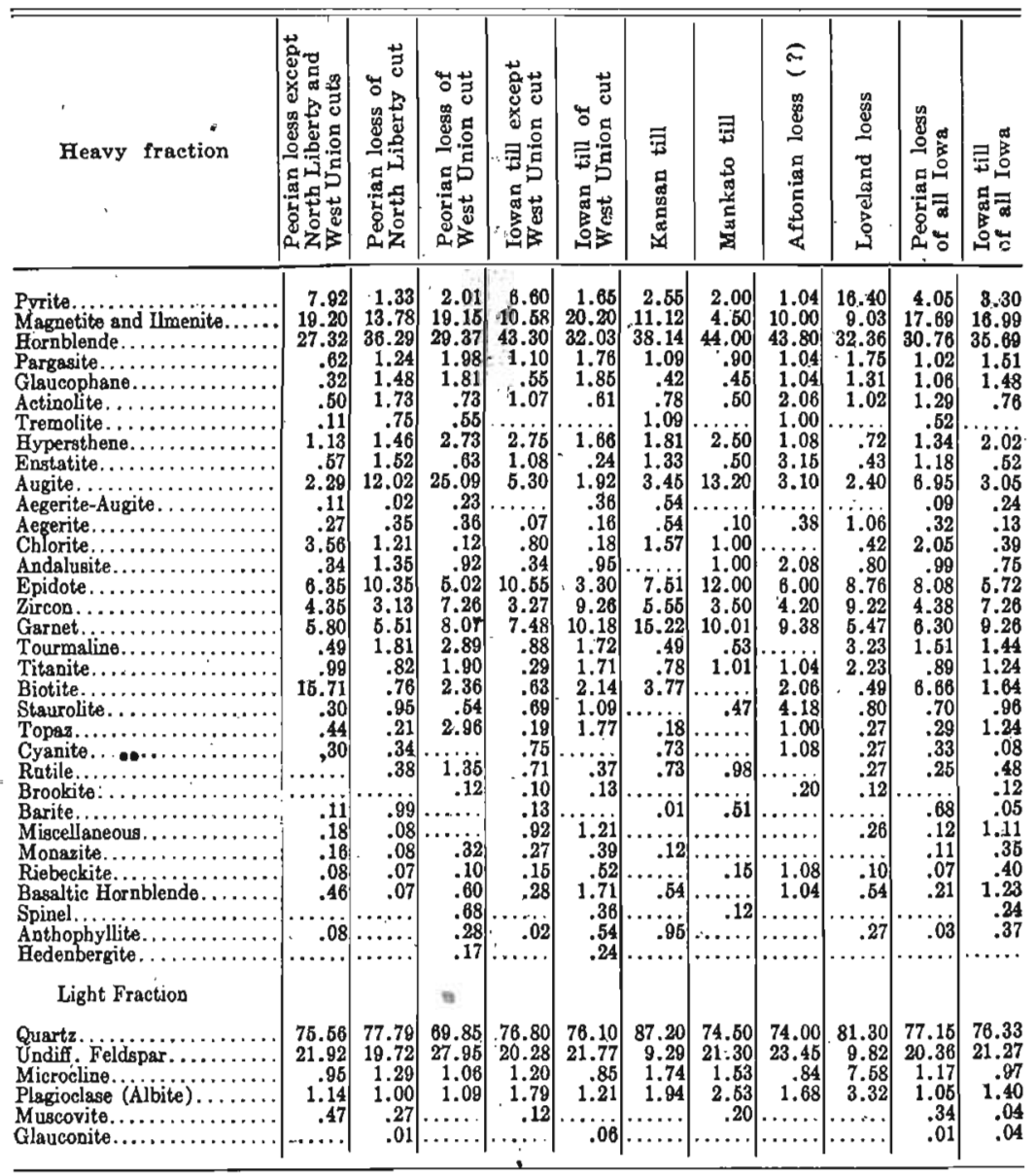

Figure 64. Mineralogical analyses of various Pleistocene materials of Towa. 
of the material becomes finer with increased distance from the Iowan drift border. The loess east of Ridgeway is all typical loess but some sections near the Iowan drift border west of West Union are composed of dominantly fine,sand.

\section{Mineral Analyses}

Petrographic studies have been made by P. T. Miller of a large series of samples of Loveland loess, Peorian loess, Iowan till, Kansan till, and other materials for the purpose of comparison. The minerals of specific gravity greater than 2.89 were separated from those lighter' by using a heavy liquid (bromoform) in a centrifuge. Each mineral separate was studied under both binocular and petrographic microscopes. The minerals of each of these separates were mounted for study in liquids of different indices of refraction. The mineralogic percentages of both the heavy and light fractions of the several Pleistocene materials are shown in figure 64 .

The striking correlation between heavy minerals of Loveland loess, Peorian loess of all Iowa, Iowan till of all Iowa, and Kansan till is readily seen (fig. 65). The Iowan till of the West Union cut and the Iowan till of all Iowa closely resemble each other as do the Kansan till and the Iowan till of all Iowa. That the Peorian

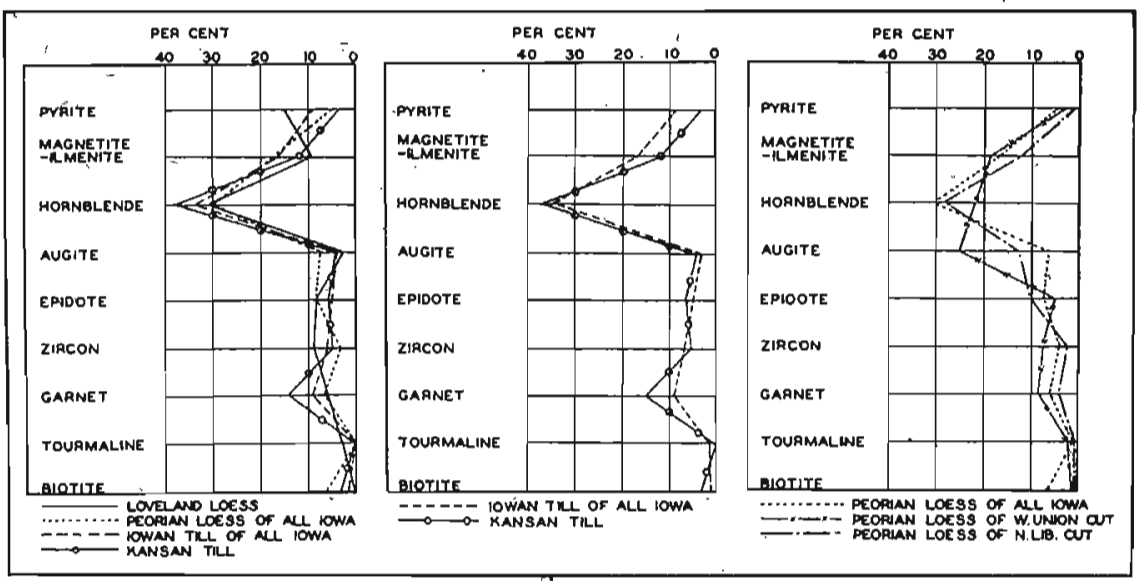

Figure 65. Graphs illustrating the correlation of heavy mineral percentages of Peorian loess, Iowan till, Loveland loess and Kansan till, of Iowa.

has slight local differences from place to place is brought out in the chart that compares the loess of the West Union cut and the North Liberty cut with the Peorian loess of all Iowa. 
From these results it seems fair to assume that the tills furnished the ultimate source of the loess derived directly from the flood plains of the Missouri River. The Peorian deposits of eastern Iowa came presumably largely from the Iowan drift and outwash.

\section{Chemical Analyses}

Samples of Peorian loess chosen from two localities where the loess has been studied in great detail with respect to physical, mineralogical and fossil relationships, were submitted to Dr. L. C. Thomas for complete chemical analysis. The analyses of the chemical components of the two loess samples are given in the following charts:

Peorian loess, from the NW1/4 NEI/4 sec. 1, Penn Township, (T. $80 \mathrm{~N}$. R. 7 W.), Johnson County. Sample taken 5 feet below the surface. Leached.

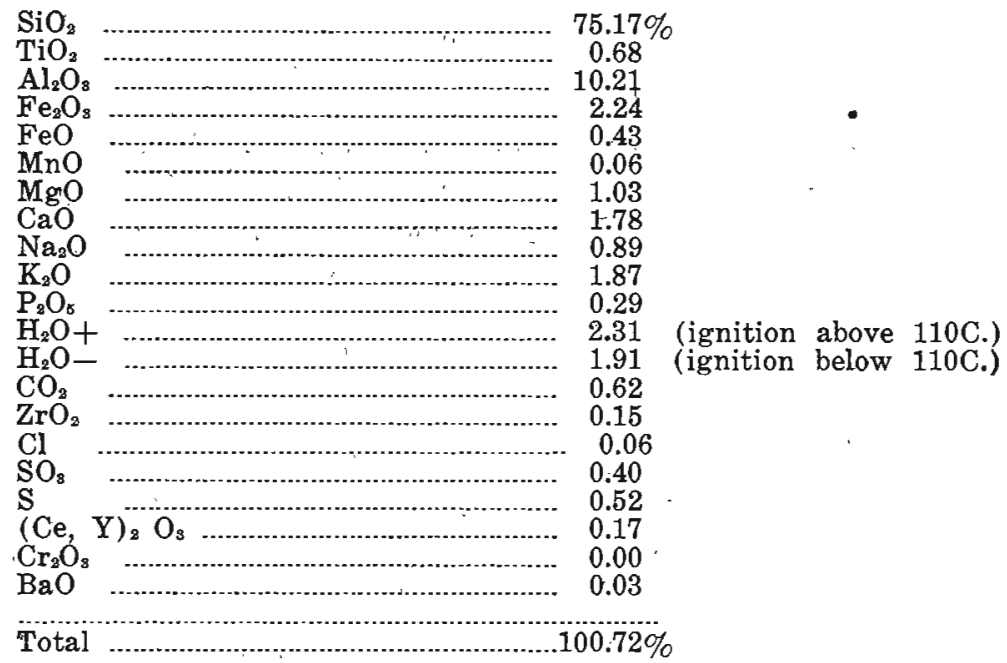

A loess analysis was made of a sample from a second section in Fayette County:

Peorian loess, from near the middle of the north line of the NE1/4 sec. 16,. Windsor Township. ( T 94 N., R 9 W.), 6 inches above the contact with the underlying till. Unleached.

\begin{tabular}{|c|c|c|}
\hline \multicolumn{3}{|r|}{$63.92 \%$} \\
\hline $\mathrm{TiO}_{2}$ & 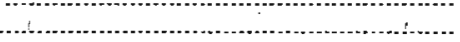 & 0.77 \\
\hline $\mathrm{Al}_{2} \mathrm{O}_{3}$ & (n) & 8.05 \\
\hline $\mathrm{Fe}_{2} \mathrm{O}_{3}$ & (n) & 1.38 \\
\hline $\mathrm{FeO}$ & ....... & 0.27 \\
\hline $\mathrm{MnO}$ & - & 0.06 \\
\hline $\mathrm{MgO}$ & …-1, & 3.85 \\
\hline & & \\
\hline
\end{tabular}




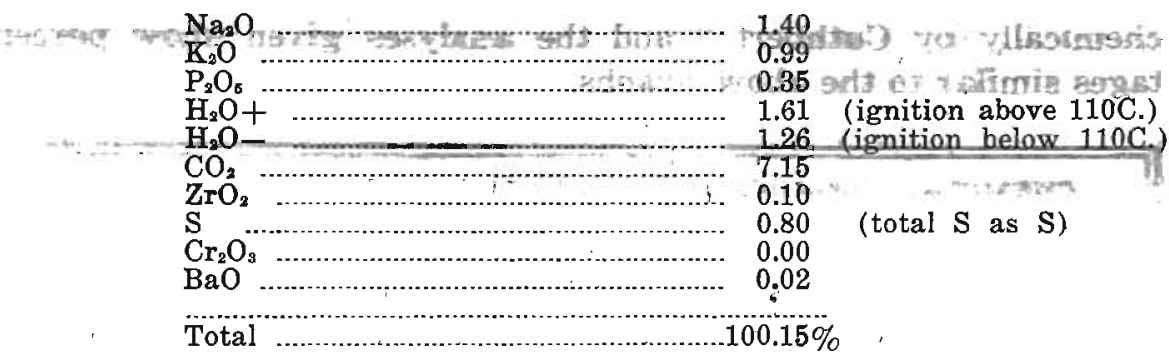

A tabulation of 45 samples of published analyses of loess and loess-like material, along with the bibliographic source of each sample, has been prepared by Dr. Thomas. This tabulation is given in chart 1 of the appendix. A comparison of the two Iowa analyses with the analyses listed in chart 1 clearly shows that the loess of these two sections in Iowa is very similar in composition to many of the samples reported in the literature, whether they were taken from the Upper Mississippi River Basin or from China or the Rhine Valley.

Several other analyses of leached Peorian loess were made by Dr. J. N. Pearce in order to compare the $\mathrm{SiO}_{2}, \mathrm{Fe}_{2} \mathrm{O}_{3}, \mathrm{Al}_{2} \mathrm{O}_{3}, \mathrm{CaO}$, and $\mathrm{MgO}$ content. The localities from which the loess was taken are as follows:

A. From cut on Chicago, Milwaukee, St. Paul and Pacific Railroad, 1 mile west of Murray, (T. 72 N., R. 27 W.), Clarke County.

B. From cut west of the Chicago Great Western Railway crossing, Union County.

C. From cut on the Chicago, Milwaukee, St. Paul and Pacific Railroad about 1 mile east of Foster. (T. 71 N., R. 16 W.), in the southeast corner of Monroe County.

D. From cut west of Agency, (T. 72 N., R. 13 W.), Wapello County.

E. From bluff north of Fort Madison, (T. 68 N., R. 4 W.), Lee County.

F. From cut northwest of North Liberty, (T. 80 N., R. 7 W.), Johnson County.

G. From cut on Chicago Rock Island and Pacific Railway near the north boundary of sec. 3, Lincoln Township, (T. 72 N., R. 21 W.), Lucas County.

Figure 66 shows the chemical analyses made by Pearce in graph form of leached Peorian loess from these seven sections.

The seven analyses show close similarities, the greatest variation being in the $\mathrm{SiO}_{2}$ content. A comparison of these analyses of leached loess with the unleached loess of the West Union section, sec: 16, Windsor Townshipp, (T. 94 N., R. 9 W.), Fayette County, shows a marked increase in $\mathrm{CaO}$ and $\mathrm{MgO}$ in the unleached loess.

Two specimens of Peorian loess from Marshall and Cass Counties respectively have been analyzed in detail mechanically and 
chemically by Cuthbert ${ }^{103}$ and the analyses given show percentages similar to the above graphs.

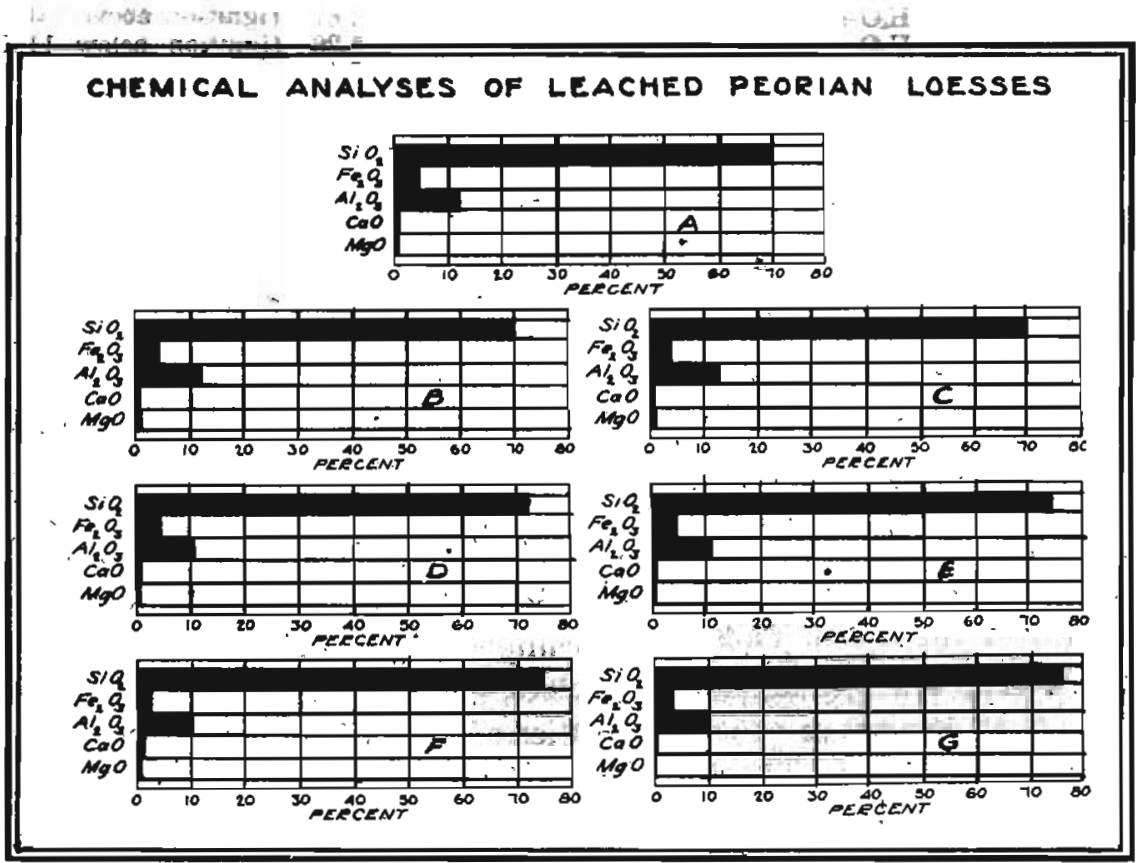

Figure 66. Graph showing the chemical analyses of leached Peorian loess.

Fossils of the Peorian Loess

\section{Vertebrates}

There is a striking paucity of vertebrate fossils reported from the Peorian loess of Iowa. Just why this scarcity should be, wnen other indications point to a great abundance of mammals inhabiting the area has not been clearly understood. The most plausible argument is that the conditions for burial and preservation of skeletal parts by the wind-blown silt and clay were unfavorable, and that in most cases complete decay of the bones and teeth occurred before burial.

There is little doubt but that a rich vertebrate fauna existed in Iowa and surrounding areas throughout Wisconsin time. The abundance of both forest and plains mammals preceding the Wisconsin epoch, and the rich cave and flood-plain faunas associated with early man in America would seem to span the interval under 519-527, 1940 . 
consideration. Deposits which may include the entire range of the Wisconsin epoch, such as Conard's Fissure in Arkansas, indicate no impoverished zone which might be correlated with a Peorian scarcity of life.

The loess as a preserving medium for organic remains is chemically and physically well suited for the purpose. A good terrestrial matrix for vertebrates should be fine enough so that damage to the organic remains does not occur in deposition; there should be sufficient porosity and permeability to permit solution and mineralization of the bones; and the matrix should contain sufficient mineral content to afford the mineral replacement occurring in normal fossilization. While the organic remains which have been found in the Peorian loess are not highly silicified, the essential qualities of a good preserving material are met.

Therefore, the lack of fossils must be due to conditions of burial, and there are several lines of evidence to substantiate this view. Except in a few localities, the accumulation of Peorian loess must have been exceedingly slow. Considerably more than half of the state has a covering of somewhat less than 10 feet of loess. It may be that the lack of numerous vertebrate fossils in the loess in Iowa is due largely to insufficiency of cover before the normal decay and disintegration of organic remains on the prairie or forest floor was complete. The absence of any well-defined soil zones in the Peorian loess of Iowa, ${ }^{104}$ and the uninterrupted climatic sequences of the invertebrate fauna in the loess suggest that accumulation was fairly uniform. While the evidence in Iowa indicates that the loess was deposited very early in the Peorian interval, perhaps its rate of deposition was so slow that only the most minute of the readily perishable organic remains were covered and preserved.

A few vertebrate-bearing deposits of the loess are: known. In most instances known to the authors, these localities show unusual thicknesses of the loess, those in Nebraska ranging up to 200 feet. $\mathrm{McGee}^{105}$ reported the discovery of part of a skull of the extinct musk ox Symbos cavifrons in Peorian loess near Council Bluffs, Pottawattamie County. Shimek, whose study of the Peorian snail fauna led him to conclude that the loess was an inter-

\footnotetext{
IotSeveral thin soil zones in the upper part of the Peorian loess in western Nebraska have been identified by Nebraska geologists. These fossil soils and the related soil zones in the Sand Hills formation are being studied by Drs. Lugn and Schultz, Department of Geology, University of Nebraska: Personal communication.

100McGee, W J, Ovidos Cavifrons from the loess of Iowa: Am. Jour. Sci., vol. 34, p. $217,1887$.
} 
glacial deposit, suggested that this aretic type af mammal may have come from the Loveland rather than the Peorian. However, McGee describes the fossil as occurring at a depth of 12 feet in the loess, and at a height of 130 feet above the river level, an elevation higher than known Loveland oceurrences, but well within the Peorian range which in this area may attain a depth of one hundred feet.

Udden ${ }^{106}$ reported that the horn cores of a bison; probably Bison occidentalis, had been found in the loess also in Pottawattamie County, in a well at a depth of 14 feet.

There is some doubt about a discovery reported by Todd, ${ }^{107}$ of tusks, teeth, jaws, a humerus, and other bones of a young elephant found between Glenwood and Pacific Junction, Mills County. The remains may have come either from the basal part of the thick Peorian loess or from the top of the underlying drift.

Also from Mills County, Udden ${ }^{108}$ reported the finding of bones of a mammoth in the lower part of the loess at Malvern in a grading for the Chicago, Burlington and Quincy Railroad.

Perhaps one other Iowa section bears out the probable relation between depth and preservation of organic remains. In the Mitchellville cut, described on pages 169 to 171 of this report, well preserved logs and branches are conspicuous, an unusual occurrence in the Peorian loess. Accentuating this feature is the abnormal thickness of this section, which has a known depth of at least 58 feet though overridden by the Mankato glacier. The wood from this deposit is well preserved, and indicates fairly rapid burial.

In Nebraska, a very rich mammalian horizon known as the "Citellus Zone" occurs in the transition zone between the Loveland and Peorian loess phases. The zone includes the deep soil zone which has developed on the Loveland, loess, and the basal 4 feet of Peorian loess. This zone has yielded many vertebrate specimens, and the great thickness of the Peorian, here perhaps the thickest definite Peorian loess in America, strongly favors the relation of the fossil remains to a quick burial of the mammals living on the old Loveland soil surface, by the great dust storms of early Peorian time. This zone, because of its recognizable

\footnotetext{
${ }^{100}$ Udden, J. A., Geology of Pottawattamie County: Iowa Geol. Survey, vol. 11, p. 260, 1901. 10rTodd, J. E., Notes on the Geology of northwestern Iowa: Iowa Acad. Sci., Proc., D. 14, 1875-1880.

${ }_{106}$ Udden, J. A., Geology of Mills and Freemont Counties: Iowa Geol. Survey, vol. 13, p. 170, 1908.
} 
character and fossil significance, has become an important datum in western Pleistocene stratigraphy. ${ }^{109}$

\section{Invertebrates}

The invertebrate fauna of the Peorian loess in Iowa has been recently studied in detail by Cameron. The following list of mollusks in the Peorian loess has been taken from the report of that investigation. ${ }^{110}$

\section{Gastropoda}

Terrestrial Pulmonata

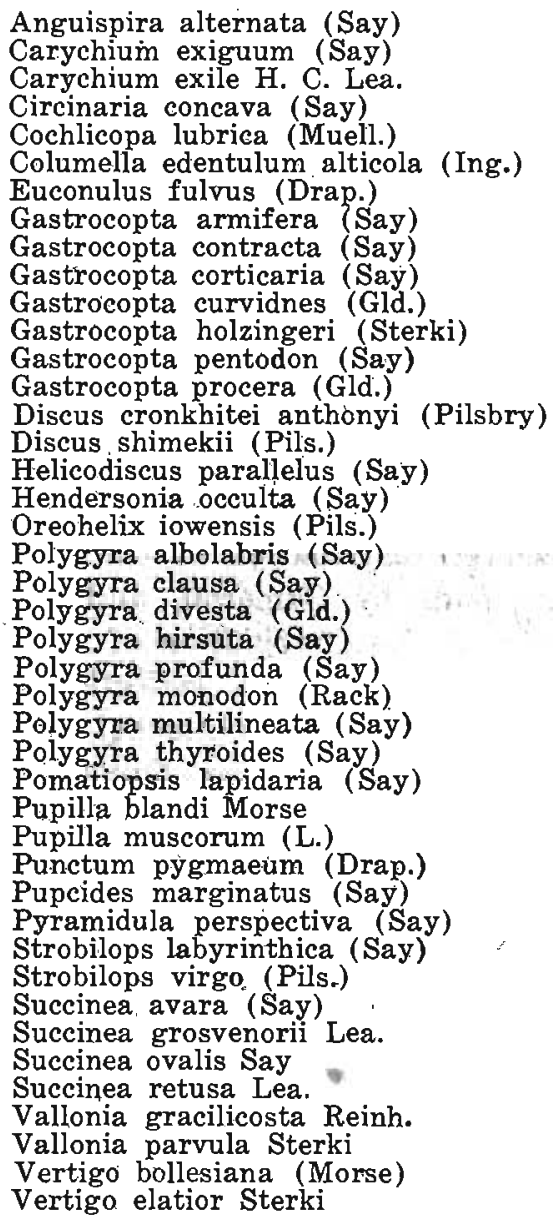

${ }^{100}$ Schultz, C. B., The Plelstocene mammals of Nebraska, Nebraska State Mus., Bull, vol, 1, pp. $859-360,1934$,

${ }^{10}$ Cameron, Cornelia, Fossils of the Peorian loess of Iowa: Thesis, Dept. of Gealogy, State Univ. of Iowa, 1940 . 


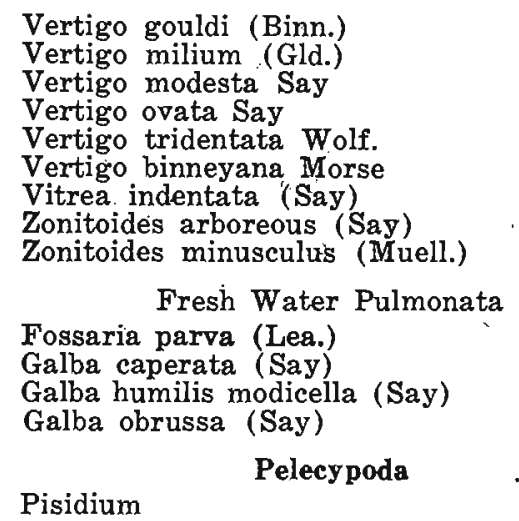

The above faunal list has been compiled from 16 loess sections distributed widely over the important loess areas of the state, and permits several generalizations as to Peorian climate and vegetation.

The 56 species of gastropoda and the single pelecypod which have been identified by Cameron from the Peorian loess are all species which are living today, a representative group of which are shown in figure 67. This fact is of the greatest value in reaching a Peorian climatic interpretation for it allows a study of the ecologic variations of the modern snail fauna which can then be compared to the observed distribution of the fossil forms. This comparison has been made by Cameron, and, some remarkably parallel conditions in both the distribution of species, and in the size variations (considered here as a reflection of the relative dampness or dryness of the local environment) are noted between the modern and the fossil faunas. This similarity suggests that the plant geography of the state in Peorian time was little different from that of today, except possibly for a greater admixture of deciduous and coniferous trees in the forests, resembling the present-day forests of Wisconsin and Minnesota. A constant forest-prairie relationship over the state as a whole seems to have persisted from Peorian time until the present, although the faunal profiles from the thick loess near the Iowan glacial border show a general change from deep forest conditions during early loess deposition, to forest border or prairie conditions during upper loess deposition. In a similar succession, the faunal profiles of the deep loess along the Mississippi and Missouri Rivers reflect the damp; protected, deep forest environment of early Peorian 


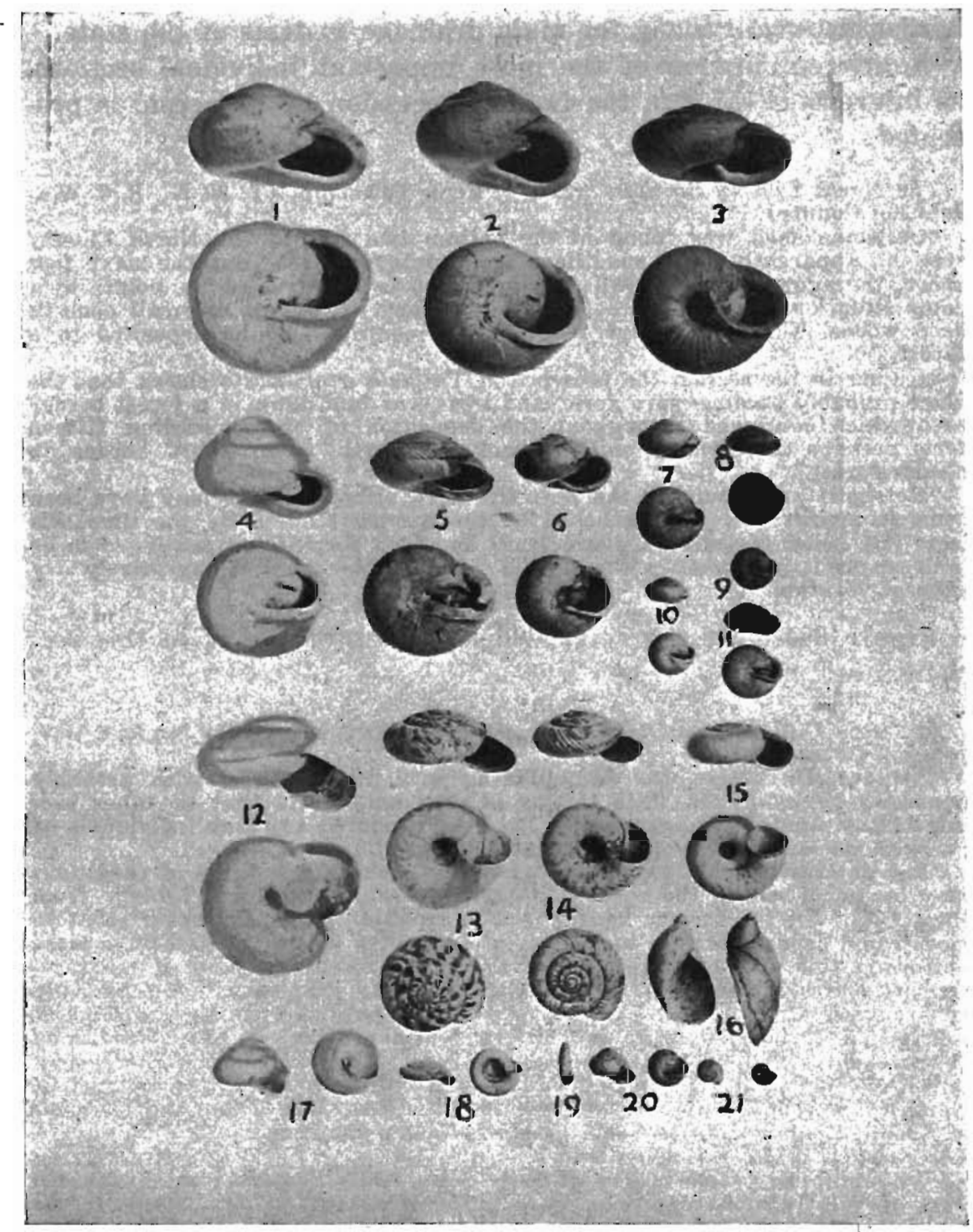

Figure 67. Terrestrial gastropods of the Peorian loess of Iowa. (After B. Shimek):

time but as the hills were built higher and the predominent westerly winds exerted a stronger ecologic influence on the flora and fauna of the forest floor, the fossils change to more xeric types, developing into the forest border and prairie fauna found in those areas today. Dense forests persisted back from the glacial 
border, especially along the main drainage systems of the state.

A brief discussion of the more important individual sections, as interpreted through the faunal succession by Cameron, is presented :

The North Liberty Section: (Sec. 1, Penn Township, (T.' 80 N., R. 7 W.), Johnson County)

"Only one shell was found in the bottom two feet of the North Liberty section. Apparently local conditions were unfavorable. But the next foot above, the aggregation of shells among which is Fossaria parva, points to a damp situation which might be found at a seepy place, bog, or small pond in deep woods. The next twelve feet of loess continued to be deposited in a forest.

"Higher in the section the presence of Vallonia gracilicosta shows that the place probably became more xeric, and loess was laid down in a forest border area' which continued throughout the deposition of the succeeding fifteen feet; perhaps there was a shifting back and-forth from forest border to deeper forest.

"No shells were found in the next five feet, although there may have been some in nearby places not reached by the narrow section. By the time this loess was being deposited a distinct hill had been formed. It continued to be built up as it supported a fluctuating forest border in a comparatively dry exposed location."

Figure 68 shows the vertical distribution of fossils in this section.

The Iowa City Section: (Sec. 2, East Lucas Township, (T. 79 N., R. 6 W.), Johnson County).

"At Iowa City loess was accumulating in a deeper forest with probably numerous boggy places. This section is very unusual in that no other section in any part of the loess region has ever produced as many individuals of Fossaria parva, a relatively uncommon loess shell.

"It is interesting that two cuts illustrating such different sets of conditions may be found within the short distance that separates North Liberty from Iowa City. At the former locality the unfossiliferous sandy layers point to more rapid deposition than took place at lowa City where the deposit is more uniformly fine grained. Again, there are fewer fossils per unit of measurement at North Liberty than at Iowa City. This fact coupled with the presence of Oreohelix iowensis and Vallonia gracilicosta, two shells of dry regions, at North Liberty but not at lowa City further emphasize the xeric conditions at that place. At Iowa City, on the other hand, Fossaria parva, Pupilla muscorum, Hendersonia. occulta, and Polygyra multilineata are found, but not at North Liberty in the upper forty-nine feet of loess. This group and especially Fossaria parva point to a more sheltered damp situation."

The Sections in Northeastern Iowa

"While the first few inches of loess were being deposited on Iowan till west of West Union conditions were unfavorable for snails. Similarly, no shells were found at the very base of the loess at the margin of the Iowan in the North Liberty section. In the remaining upper foot Helicodiscus parallelus occurs. This shell belongs to the group which is widely distributed over North America. It is found all over the United States and ranges northward to Manitoba where it is reported as rare.

"No fossils were found in the section east of West Union. Possibly vegetation in this area was not the type to support snail life, or perhaps their absence is due to variation in distribution.

"Shells are not abundant in the loess at the mouth of Yellow river, but those present point to a prairie which later became heavily forested. This condition remains to the present." 


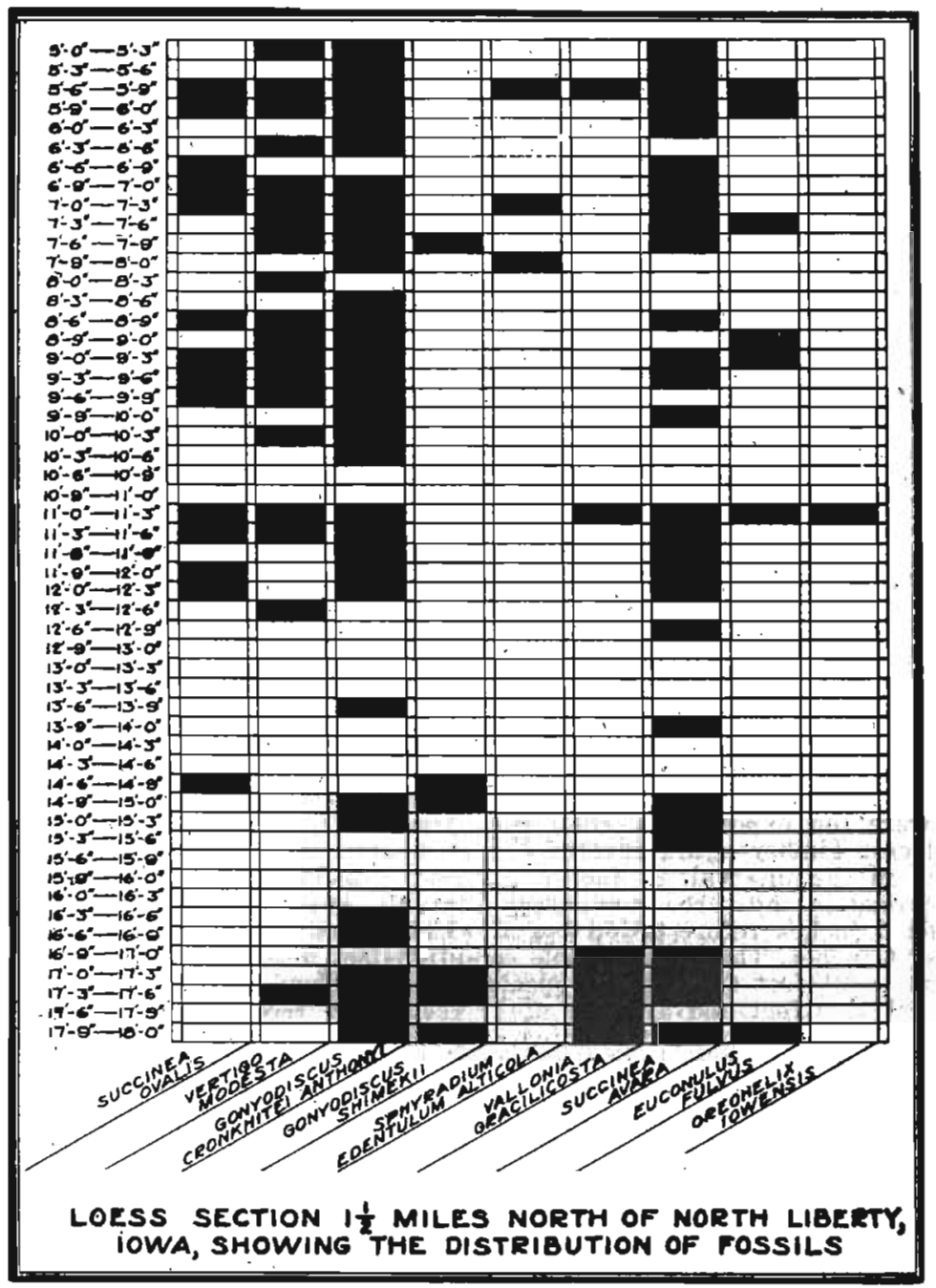

Figure 68. Graph showing the vertical distribution of fossils identified in the loess section near North Liberty, Johnson County. (After Cameron).

\section{The Sections in Southeastern Iowa}

"No shells occur in the lower one and one-half feet of: loess in Wild Cat Den State Park. They are common, however, in the overlying six inches. The aggregate indicates a forest and conditions similar in the park today. Going up the section from this interval fossils become less common and of the variety which is very adaptable. It is probable that the forest floor rose gradually and continually until the present level was reached.

"As Succinea avara was the only fossil found in the Scott county section it is difficult to draw conclusions concerning this location. Succinea avara is too widely distributed both geographically and ecologically to use as a key fossil. 
"The fossils of the Henry county section have a very unequal vertical distribution. None was found in material taken from six inch intervals. The six species collected were probably washed from a local pocket. With the exception of one they belong to deep woods. Vallonia gracilicosta is definitely a prairie species. It is likely that the loess was deposited upon a prairie which later became timbered. The region where the section was taken is wooded."

The Polk.County Section: (Sec. 15, Franklin Township, (T. 80 N., R. 22 W.), Polk County).

"The section near Mitchellville in :Polk county is particularly significant because fragments of wood and logs are closely associated with the abundant shells. The wood, spruce and hemlock, occurs throughout the section. Fossils taken directly from beneath logs are: Fossaria parva, Discus cronkhitei antonyi, Polygyra monodon, Succinea ovalis and Vertigo modesta. This collection indicates that the loess was laid down upon a rising succession of swampy forest floors, on seepage places, or in tiny ponds. The damp conditions must have played an important part in preserving the wood.

"The lower six inches of the section is unfossiliferous. The next interval contains only Vertigo elatior, a widely distributed species. In the overlying intervals the shells are those of forest species with the fresh-water pulmonate, Fossaria parva, occurring commonly until the depth of forty-three feet is reached. From this depth to the top of the section the shells belong to a drier forest area. The trees, probably, were of the deciduous and coniferous type similar to those of today found in northern Minnesota and Wisconsin."

Section in Washington Township; Fremont County: (Sec. 29, Washington Township, (T. 67 N., R. 42 W.), Fremont County) .

"This fifty foot section is located" on the bluffs of the Missouri river in southwestern Iowa.

"The lower eleven feet of the section from 50 feet to 39 feet records a history of loess deposition in dense forest. The snails were those which thrived in rather moist heavy woods. But the conditions of the overlying five feet were too exposed for snail life. Almost no shells were collected from this loess. Timber again covered the area until a well developed forest appeared in the interval, 31 feet to 31 feet 6 inches. Another local exposure is recorded in the three succeeding intervals, but in the interval 29 . feet to 29 feet 6 inches reforestation began which lasted to the interval 25 feet to 25 feet 6 inches. Then unfavorable conditions set in and not until the interval 21 feet to 21 feet 6 inches do species appear. They occur sparingly through the next five feet and are lost at 17 feet to 17 feet 6 inches. However, a dense forest developed in the interval 14 feet to 14 feet 6 inches and did not recede far during the remainder of loess deposition. There are many forest border shells from this interval to the zone of leaching."

Section in Glenwood Township, Mills County. (Sec. 12, Glenwood Township, (T. 72 N., R. 43 W.), Mills County).

"This section records a history. of a well-developed forest which became more exposed and dry throughout loess deposition."

The Missouri Valley Section: (Sec. 10, St. Johns Township, (T. 78 N., R. 44 W.), Harrison County).

"The-fossils in the Missouri Valley section show that the basal Peorian loess was deposited on the rising floor of a highland woods. After four and one-half feet were laid down the hill became too exposed to the dry west winds to support vegetation sufficient to feed and shelter snails. The overlying $251 / 2$ feet were deposited on a dry prairie similar to the present prairie openings on the high bluffs along the river."

The Loveland Section: (Sec. 3, Rockford Township, (T. 77 N., R. 44 W.), Pottawattamie County).

"The Loveland section is quite interesting" because it contains two species,

Anguispira alternata and Gastrocopta armifera which are very uncommon in the loess of Iowa.

"Anguispira alternata is very common in the southern loess of the Missiissippi Valley, and today in Iowa the recent shells are very common and widely distributed. The animal apparently has increased its northern migration since the Peorian. 
"Gastrocopta armifera is likewise far more common in Iowa today than as a loess fossil, but its present distribution is more widespread than that of $A n$ guispira alternata.

"The fauna of this section is very typically forest border in type."

The Woodbury County Section: (Sec. 31, Union Township, (T. 89 N., R., 42 W.), Woodbury County).

"The loess in this area was deposited in an upland woods which became more xeric as the surface rose.".

The horizontal change in the fauna across the state has been described in the following manner:

"If the loess fauna is traced northward and across Iowa it will practically duplicate the variations which are noted in the modern fauna. The larger species gradually disappear, and finally in much of the loess of Iowa and Nebraska only the smallex species remain, and they are largely those now living in the same area in forest border and scattered groves."

\section{Depth of Leaching in the Peorian Loess}

The Peorian interval, ás previously described, in Iowa spans the time unit which in Illinois includes the Iowan loess, Tazewell drift, Tazewell loess and Cary drift. In view of the length of time represented in the deposition and weathering of Peorian loess in Iowa, and inasmuch as the loess possibly includes the two components as found in Illinois, the Iowan and Tazewell loesses; it is to be expected that a field study of the loess in Iowa would disclose minor variations in the loess. In addition, this variation due to possible differences in time of deposition may be increased by differences in loess sources, for it is evident that the Peorian loess in Iowa had not one but several source areas supplying material not completely homologous. Thus, local differences in degree to which Peorian loess of Iowa has responded to the weathering agencies are to be expected.

The most apparent change which has occurred in the loess as a whole is the surface leaching of the calcium carbonate content. The depth of leaching, as in the older Pleistocene materials previously described, is of importance in the interpretation of time relations, and tests with acid have been carried out on the loess for many years and over the entire loess area in Iowa. The average depth of leaching is about. $5 \frac{1}{2}$ feet, which corresponds closely to the depth of leaching observed on the Iowan till, with which the Peorian loess is thought to be partly contemporaneous. This contemporaneity and the constancy of the process of leaching, whether in till or loess, would seem to be borne out by the fact that within the Iowan area, leaching in uneroded materials has progressed to a depth of about $5 \frac{1}{2}$ feet whether in Peorian 
loess, Iowan till, or thin Peorian and Iowan till. (See fig. 28, p. 108.) Thus, if a section shows 3 feet of Peorian loess on Iowan till, the till will normally be leached for $2 \frac{1}{2}$ feet. It has been found that in some cases, leaching of loess during a given time may be effected to a slightly greater depth than till, due perhaps to greater permeability of the loess or to an indigenous subnormal lime content in the loess. This difference, however, is generally not of measurable importance.

Beneath the Mankato drift, sections including Peorian loess show leaching to a depth of $2 \frac{1}{2}$ feet. The average depth of leaching of the overlying Mankato drift is $2 \frac{1}{2}$ feet making a total which, when the interval of actual Mankato ice occupancy is included, corresponds with marked equality with the average of leaching of surrounding loess areas. Sections of loess illustrating this depth of leaching in the Wisconsin drift areas are shown in figure 28, page 108 .

It is to be noted that the thicknesses of leaching here represented for the northeastern area of the Peorian loess represent in .nearly all cases the total loess thickness, with leaching of the underlying till completing the normal $5 \frac{1}{2}$ feet of leached material.

Thickness of the Peorian Loess in Iowa

There are great variations in the thickness of the Peorian loess in Iowa. The deepest sections are found in the counties bounding the western border of the state, along the east valley wall of the Missouri River. Here, where the wide flood-plain and persistent sand bars of the great river have maintained an ever replenished supply of dust and silt, the loess has accumulated to thickness of from 60 to 100 feet.

This extreme thickness of loess diminishes eastward, in proportion as the distance from the source increases, and in the south and central portions of the state, except for localized variations along major drainages, the loess averages less than 10 feet in thickness. Nearing the Mississippi River on the eastern border of the state, the loess thickens, but because of the prevailing westerly winds, the loess has aecumulated to depths of but 10 to 15 feet on the average.

Thick loess occurs about the border of most of the Iowan drift region of northeastern Iowa, in places reaching a depth of more than 50 feet, and in general making a sharp and marked contrast 


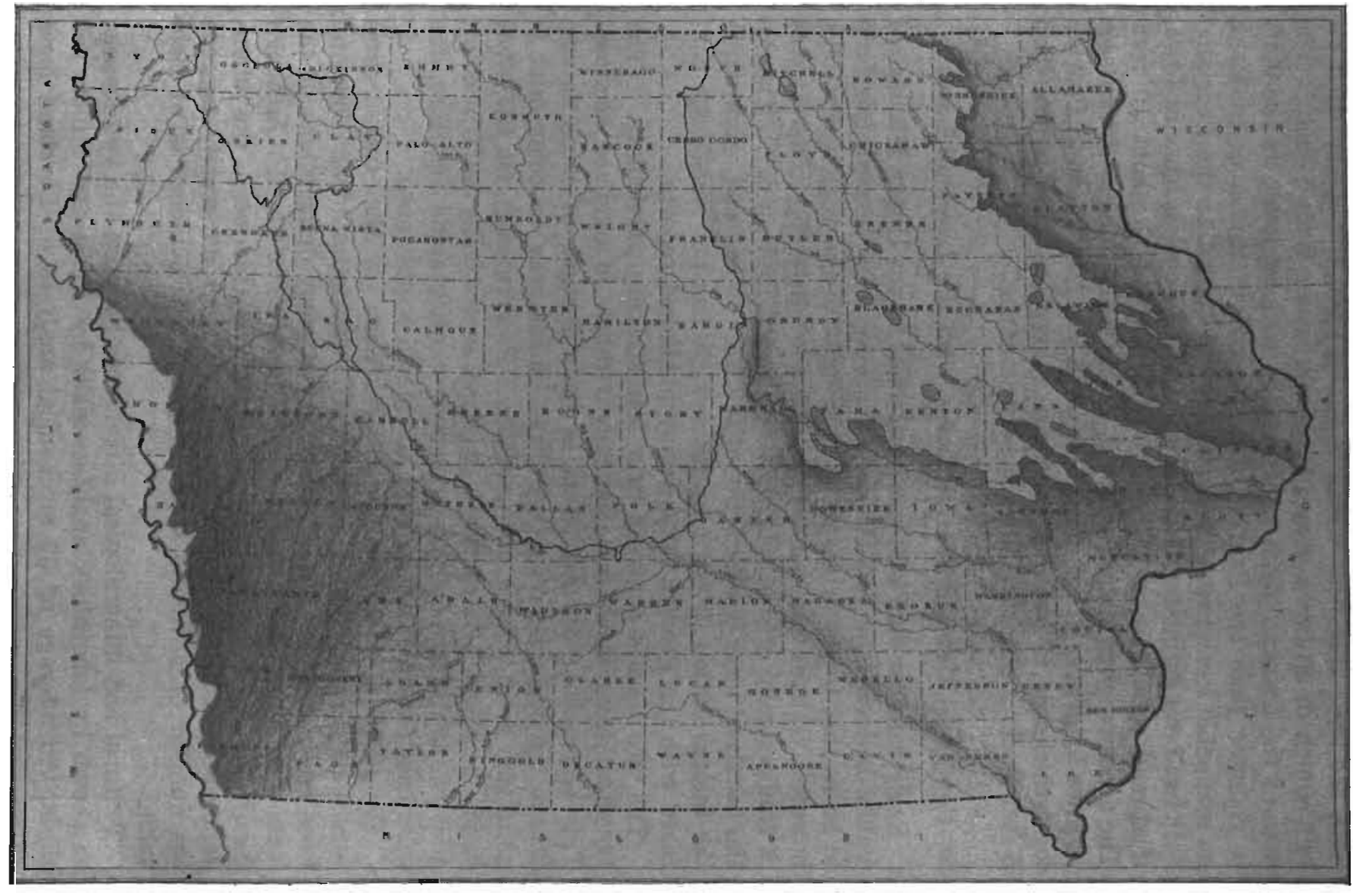

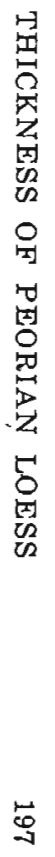

Figure 69. Map of Iowa showing relative thickness of Peorian loess by degree of shading. 
with the loess thickness which is found upon the Iowan drift itself, which in all but a very few places is less than 5 feet. . The area of the Mankato drift is essentially without loess, as the drift is younger than the Peorian deposit, and in this area at least, no mappable loess has been deposited subsequent to the Peorian.

It has been estimated that the amount of Peorian loess in Iowa, if spread equally over the entire state, would be about 10 feet. The accompanying map, figure 69, shows Peorian loess thicknesses in Iowa by degree of shading. Figure 70 is a map showing Peorian loess thickness in Iowa by contours. Where the loess is less than 5 feet thick, a number shows the thickness.

\section{Comparison of the Peorian Loess With the Loveland Loess}

Early workers on Pleistocene materials in the Upper Mississippi Valley believed the reddish compact loess now termed Loveland to be related to the widespread buff loess of the region. In 1909, however, Shimek published the statement that the material was of fluvio-glacial origin, related in age to the Kansan drift. Though the Loveland loess is now. believed to differ in age and origin from the interpretation given it by Shimek, it has not since been confused with the Peorian loess in any published reports.

The two loesses contrast in a few striking particulars. The Loveland loess is characteristically reddish in oxidized sections. This coloration does not seem to be a feature of local nature. Where the loess is unoxidized it is bluish gray in color, and is quite similar in color to the unoxidized Peorian loess. On the other hand, the Peorian loess, when oxidized, is distinctly buff in color, and where the two loesses appear in stratigraphic sequence, the color contrast is in many places sharp and readily seen.

The fossil content of unleached sections of the two loesses serves as another guide in their differentiation. The Loveland loess is but slightly fossiliferous, and in early descriptions of the loess it was stated that the loess was barren of fossils. Although fossil mollusks are known to be present in this loess, the abundance of similar fossils in the Peorian loess so greatly exceeds the number of Loveland specimens that this evidence is of field value.

Textural and mineralogical differences between the two loesses, as shown by laboratory analyses made by Apfel and Miller, are slight. An average of 35 mechanical analyses of Loveland loess 


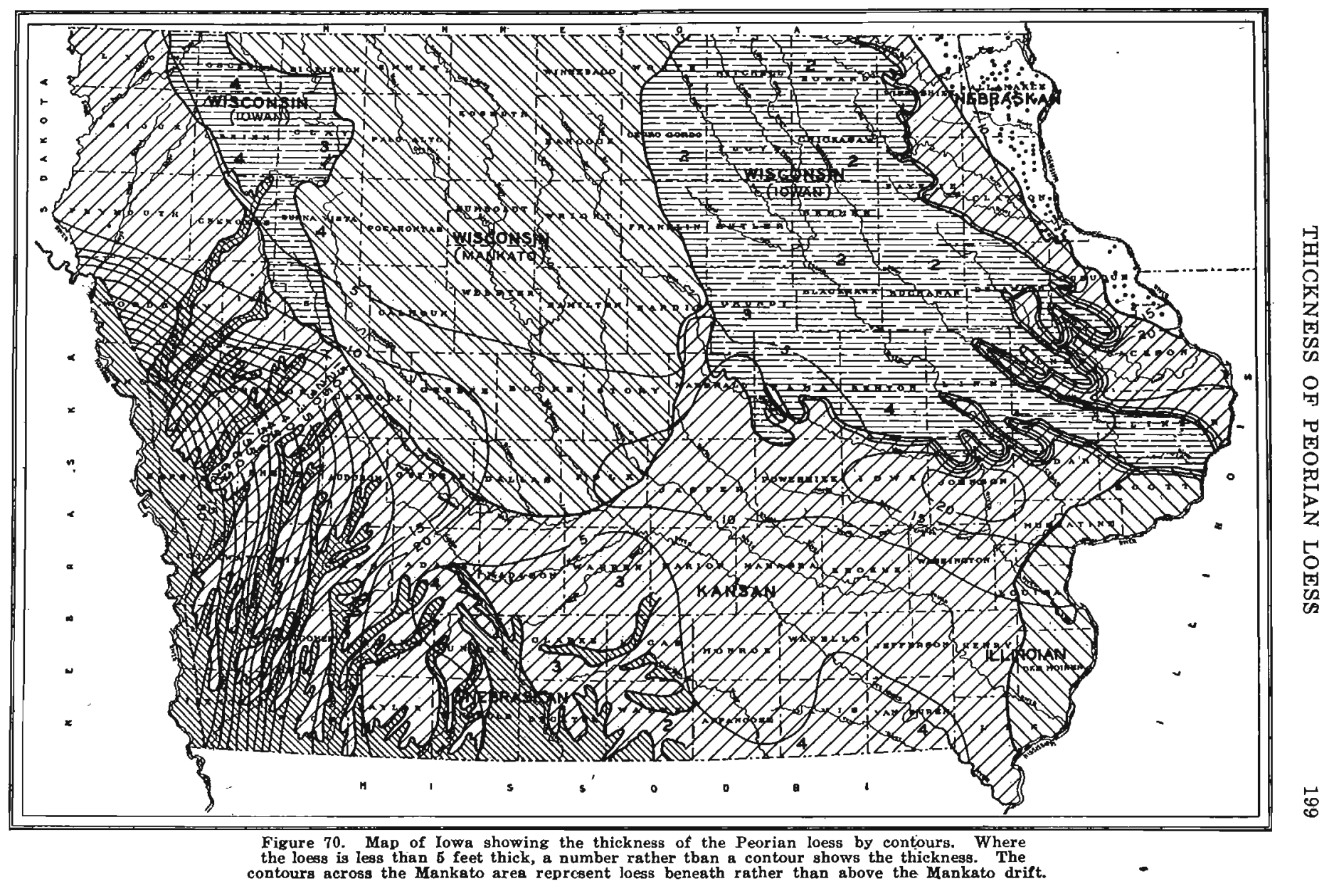




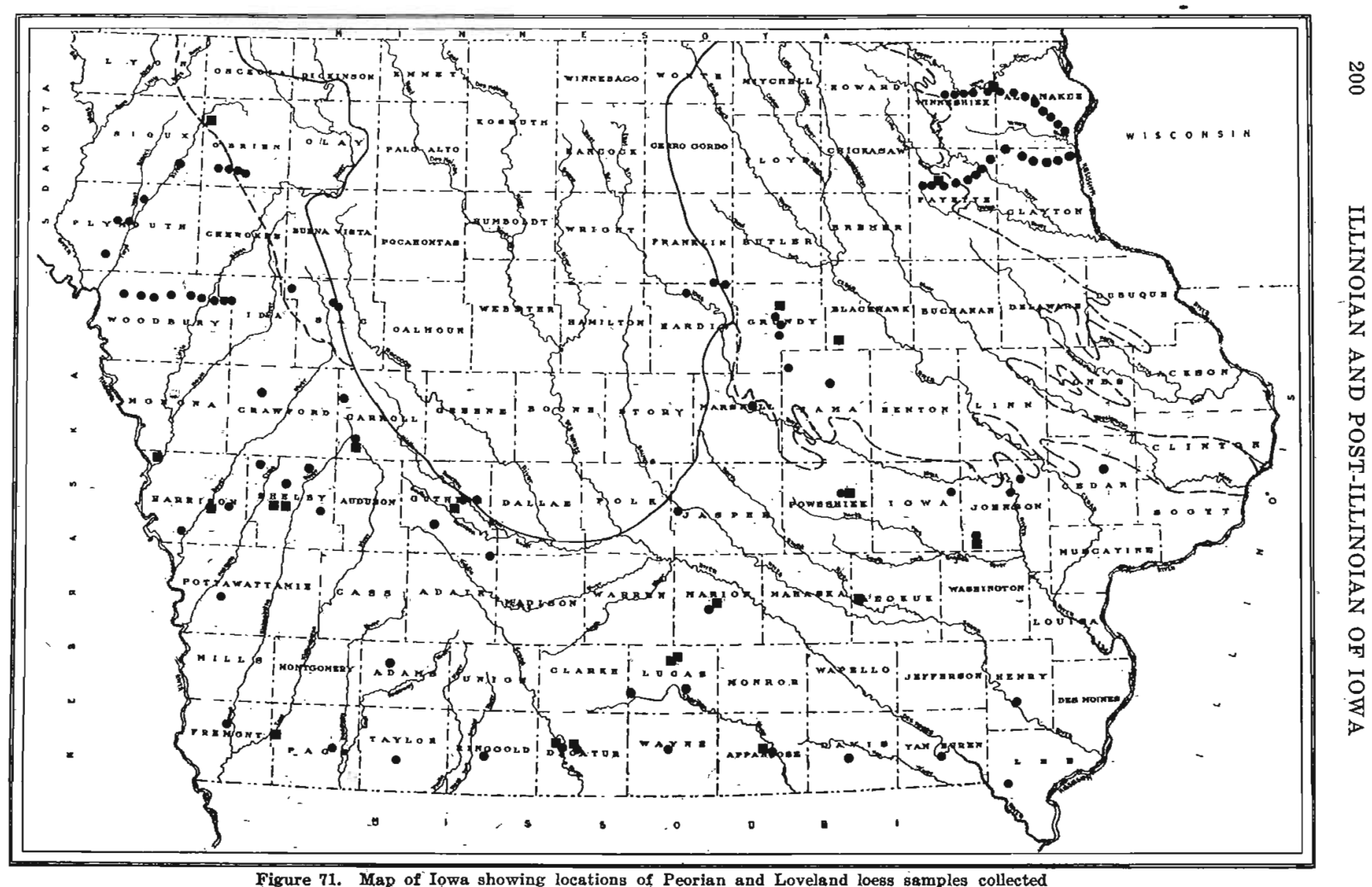

Figure 71. Map of Iowa showing locations of Peorian and Loveland loess gimples collected
for laboratory analyses.
Squares represent Loveland locations; circles represent looatlons. 
compared with about 50 samples of mechanically analyzed Peorian loess, collected over the state, figure 71, showed the following:

The material within the finest two size grades, those below 1/64 millimeter in diameter, show almost equal percentages for both the Loveland and the Peorian loesses, figure 72. In the next two coarser size grades the Peorian loess contains higher percentages than the Loveland. In the size grades above these, the Loveland contains the higher percentages. Some of the increase for Loveland loess, within the higher grades, is due to the iron which cements some of the finer material in some cases and forms small nodules in other cases. 'There is also more sand within the Loveland between $1 / 2$ and 4 millimeters in diameter than within the Peorian.

Comparative mineralogical analyses have been made by $\mathrm{P}$. T. Miller. The percentages of the major constituent minerals of the two loesses are as follows:

\begin{tabular}{|c|c|c|}
\hline Mineral & $\begin{array}{l}\text { Loveland } \\
\text { loess }\end{array}$ & $\begin{array}{c}\text { Peorian } \\
\text { loess }\end{array}$ \\
\hline $\begin{array}{l}\text { Quartz } \\
\text { Undiff. Feldspar }\end{array}$ & $\begin{array}{r}81.030 \\
9.82\end{array}$ & 20.36 \\
\hline Microcline & 7.58 & 1.17 \\
\hline Plagioclase (Albite) & 3.32 & 1.05 \\
\hline
\end{tabular}

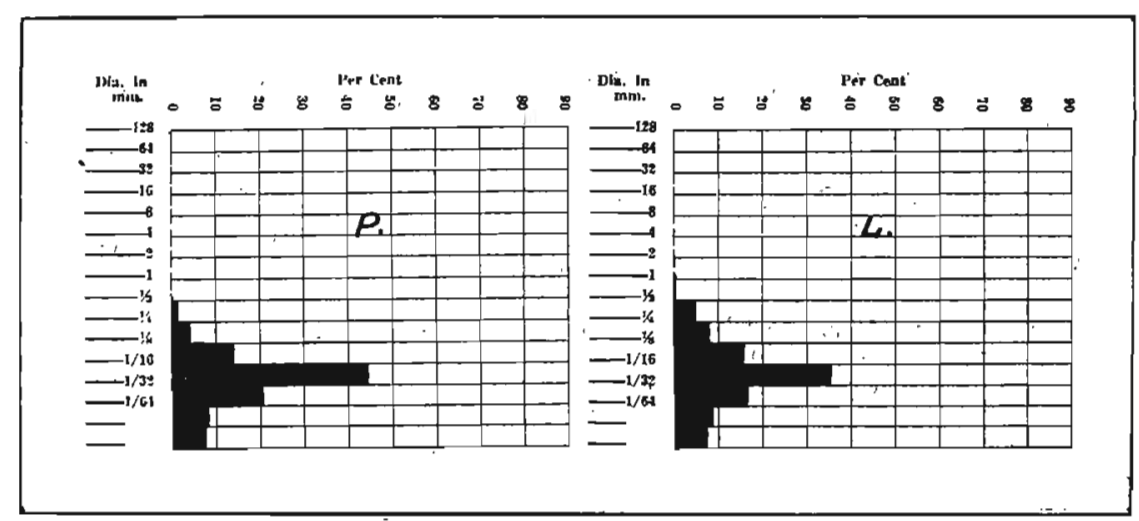

Figure 72. Graphs showing the meehanical analyses of Loveland and Peorian loesses.

The greatest percentage difference is in the undifferentiated feldspar, but this difference is not paralleled by the total percentage of feldspars in the two loesses. Neither quartz nor feldspar of one loess averages as much as 5 per cent higher or lower than the percentage of the same minerals in the other. Figure 73 shows a comparison of minor minerals. 


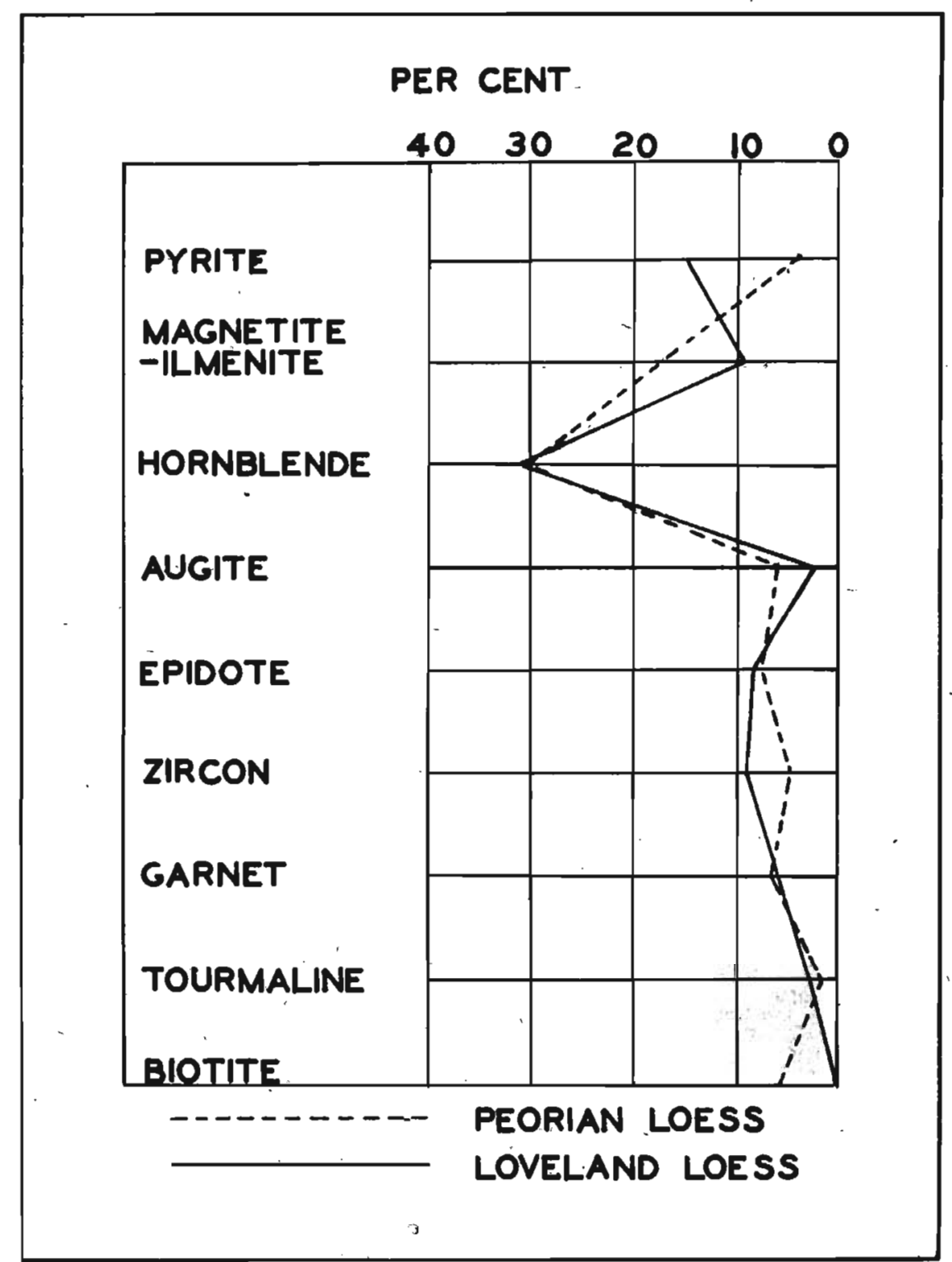

Flgure 73. Graph showing the heavy mineral anulyses of Loveland and Peorian loesses. 
There is a considerable difference in the thicknesses of the two loesses in Iowa. The Peorian loess attains a maximum depth of 90 to 100 feet in western Iowa, and it has been estimated that if all of the Peorian loess in the state were evenly distributed over Iowa it would average about 10 feet in depth. The Loveland loess, however, rarely is found in thicknesses of more than 20 to 30 feet, It is thickest, as is the Peorian, in western Iowa. In central and eastern Iowa, sections in which Loveland loess is found show that the range in thickness is in most places a few inches up to 5 or 6 feet.

\section{THE MANK ATO GLACIAL SUBAGE (SUBSTAGE)}

Discrimination of the Mankato drift

Distribution of the Mankato drift in Iowa

Origin of the drift

Changes in the drift

Typical sections of the Mankato drift

Mankato till over loess and pre-Iowan till

Mankato till over Peorian loess

Exposures showing only Mankato till or gravel

Descriptions of the drift phases

Oxidized and leached Mankato till

Oxidized and unleached Mankato till

Unoxidized and unleached Mankato till

The Mankato gravels

Mankato upland gravel

Mankato terrace gravel

Mankato morainic complex

Thickness of the Mankato dxift

Following the epic work of .Chamberlin and McGee in Iowa and adjacent states in the latter part of the nineteenth century, the presence of a young till in north central Iowa was recognized and generally accepted. Chamberlin, describing the drift series of the Mississippi Valley in Geikie's "Great Ice Age", in 1894, gave the name East Wisconsin to this fresh and uneroded drift sheet. Upon Upham's suggestion, the name East Wisconsin was changed by Chamberlin to Wisconsin in 1895, and this name, although with an expanded meaning, has been in general use to the present day.

It was found that in areas to the north and east of this lobe of the Wisconsin in Iowa, this drift could be separated into first two and then three distinct phases, and the terms Early, Middle and Late Wisconsin were applied to these substages, with the lobe in Iowa being recognized as the Late Wisconsin phase. It has come to be known as the Des Moines lobe of the Wisconsin, a reference to the relation of the Des Moines river valley to the drift outline 
and the location of the city of Des Moines at the southern extremity of the drift sheet.

In 1931, Kay ${ }^{111}$ grouped the Iowan, Peorian and Wisconsin stages together as the last of four cycles of the Pleistocene, giving the name Eldoran to this cycle. The Iowan, however, was still considered by Kay to represent a distinct glaciation, as the evidence in Iowa indicates a short but distinct break in glacial conditions between the Iowan and Late Wisconsin drifts. In the same year, Leighton ${ }^{112}$ in Illinois grouped the long discussed Iowan with the three previously recognized phases of the Wisconsin, making four substages rather than three for this last stage of glaciation, and thereby reducing the number of distinct glaciations from five to four. Two years later the names which are now accepted for these four substages were presented by Leighton, ${ }^{113}$ and the name Mankato was given to the Late Wisconsin, or Des Moines lobe of Iowa. The name was taken from the town of Mankato, Minnesota, "where the Late Wisconsin deposits are excellently displayed." In a joint paper by Kay and Leighton, ${ }^{114}$ this four-fold classification of the Wisconsin 'glaciation was designated as the Eldoran epoch, and with the inclusion of the Recent as the last interglacial age, the Pleistocene classification of the Upper Mississippi Valley became as it is today.

It is not unlikely that detailed study of the Wisconsin glacial substages in areas to the north may bring to light minor readvances of the Wisconsin lobes, and perhaps indicate more or less contemporaneous growth from the several centers of ice accumulation. Thwaites ${ }^{115}$ has differentiated the Mankato substage into Early Mankato and Later Mankato. 'Thwaites considers the "young Red Drift" of Wisconsin and Minnesota to have come from the Patrician center, and refers to evidence indicating that the "young Gray Drift", the Mankato of Iowa which had a Keewatin source, passed over moraines of the red drift of Patrician source.

\footnotetext{
w1Kay, G. F., Glassification and duration of the Pleistocene period: Geol. Soc. America Bull., vol. 42, pp. 445-452, 1931 .

rinLeighton, M. M., The Peorian loess and the classification of the glacial drift sheets of the Mississippi Valley: Jour. Geology, vol. 39 , pp. $45-53,1931$.

wiseighton, M. M., The naming of thejubdivisions of the Wisconsin glacial age: Science,

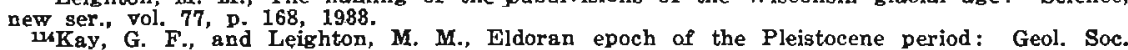
America, Bull., vol. 44, p. $669-674$, 1933 .

115Thwaites, 'F. T., Outline of glacial geology, Edwards Bros.' Inc., Ann Arbor, Michigan, pp. $84-85,1934$.
} 


\section{Distog: Discrimination of the Mankato Drift}

The Mankato drift is in many respects the most distinctive of all the drift sheets in Iowa. Its youth is reflected even to the untrained eye in its undrained character, slight alteration, and the features of original deposition such as hummocks, moraines, lakes, etc. The unincised stream shown in figure 74 illustrates the youthful character of the drift. As the position of this drift is above and later than that of the Iowan and Peorian materials, the Mankato is uncovered by loess and covers the irregularly loess-mantled surfaces of the Iowan and Kansan drifts. No mappable loess has been observed on the Mankato till surface.

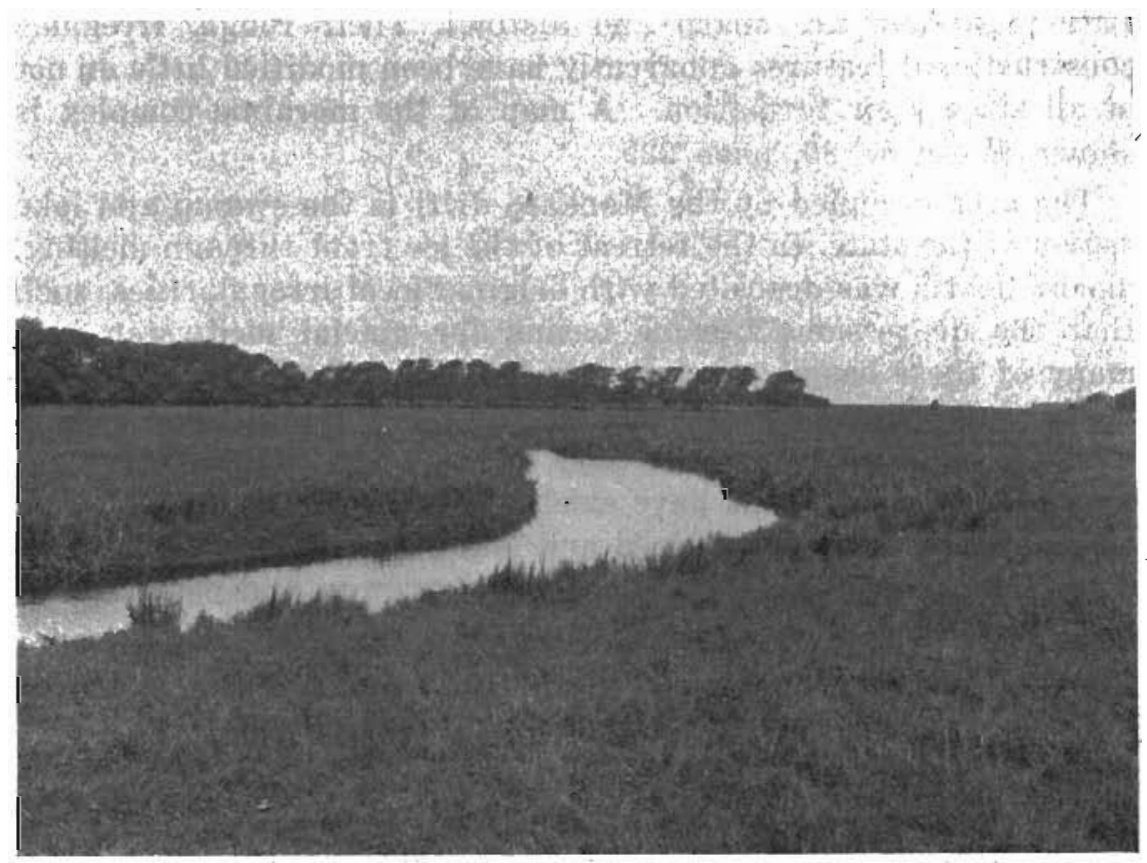
Figure 74: Stream on the Mankato drift illustrating the immature stage of erosion of the
drift. Palo Alto County.

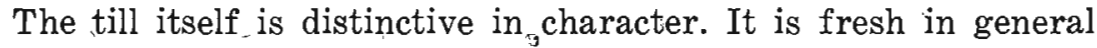
appearance. It is but slightly oxidized, and alteration by leaching has occurred only in the top 30 inches on the average. No gumbotil has had time to develop, although the incipient processes leading to its production became active immediately upon withdrawal of the ice sheet. The drift materials are composed of oxidized and 
leached till, oxidized and unleached till, unoxidized and unleached till; silt, sand and gravel from the streams of the ice sheet, and peat deposits.

An important feature which distinguishes the Mankato from other drifts is the fact that it bears a number of well-marked moraines, lateral and recessional, along its east and west.margins and across its area. A rather subdued moraine marks the western limit of the Illinoian drift sheet, but few distinctive moraines are present on the Iowan or Kansan drift surfaces. The height of land in western Iowa is probably the smoothed-out remnant of an old Kansan moraine, for here the drift is in places 500 feet or more in thickness. In contrast with these features the moraines of the Late Wisconsin are sharp and distinct. Their rough, irregular constructional features apparently have been modified little or not at all since their formation. A map of the morainic complex is shown in figure 86, page 239.

The area occupied by the Mankato drift is the swamp and lake region of the state. In the retreat of the ice front through melting, glacial debris was deposited with original local irregularities, such that the depressions became basins for glacial meltwater, and many of these basins subsequently became choked with vegetable material and have developed into the swamps and peat bogs so characterstic of the region in the days of the early settlers. However, many of the depressions have existed as lakes to the present day, and have as yet been untapped and undrained by natural processes. A sketch of the occurrence of lakes, swamps, and peat bogs in Wright County is shown in figure 75.

\section{Distribution of the Mankato Drift in Iowa}

The Mankato drift has the smallest area in Iowa of any of the drift sheets of the state, if we except the Illinoian sheet, which of course has a much greater length from its source in Labrador, and if we include that area of the Iowan sheet that now lies underneath the Mankato drift. Its lateral extent is but little over three counties or about 100 miles. The Mankato ice sheet reached into Iowa beyond the Minnesota boundary about 150 miles. Its blanket of drift occupies 14 entire counties and parts of 15 others, a total area of approximately 11,540 square miles, about onefifth of the total area of the state. Figure 76 shows the areal extent of the Mankato drift in Iowa. 
The Mankato drift sheet in Iowa is usually called the Des Moines, lobe of the Late Wisconsin, and an inspection of a glacial map of the Upper Mississippi Valley will show that it is one of several such lobes, a similar lobe in South Dakota being known as the James River lobe. While the Des Moines lobe occupies the river valley of that name it is doubtful if the valley had any great effect in determining the location, direction or limits of the tongue of ice that extended out from the main glacier. The map shows also that with one exception the margin of the lobe is fairly smooth and straight. This exception is a great indentation in northwestern Iowa, occupying parts of Osceola, Dickinson, Clay and $O$ 'Brien Counties. The reason for this indentation is not very clear.

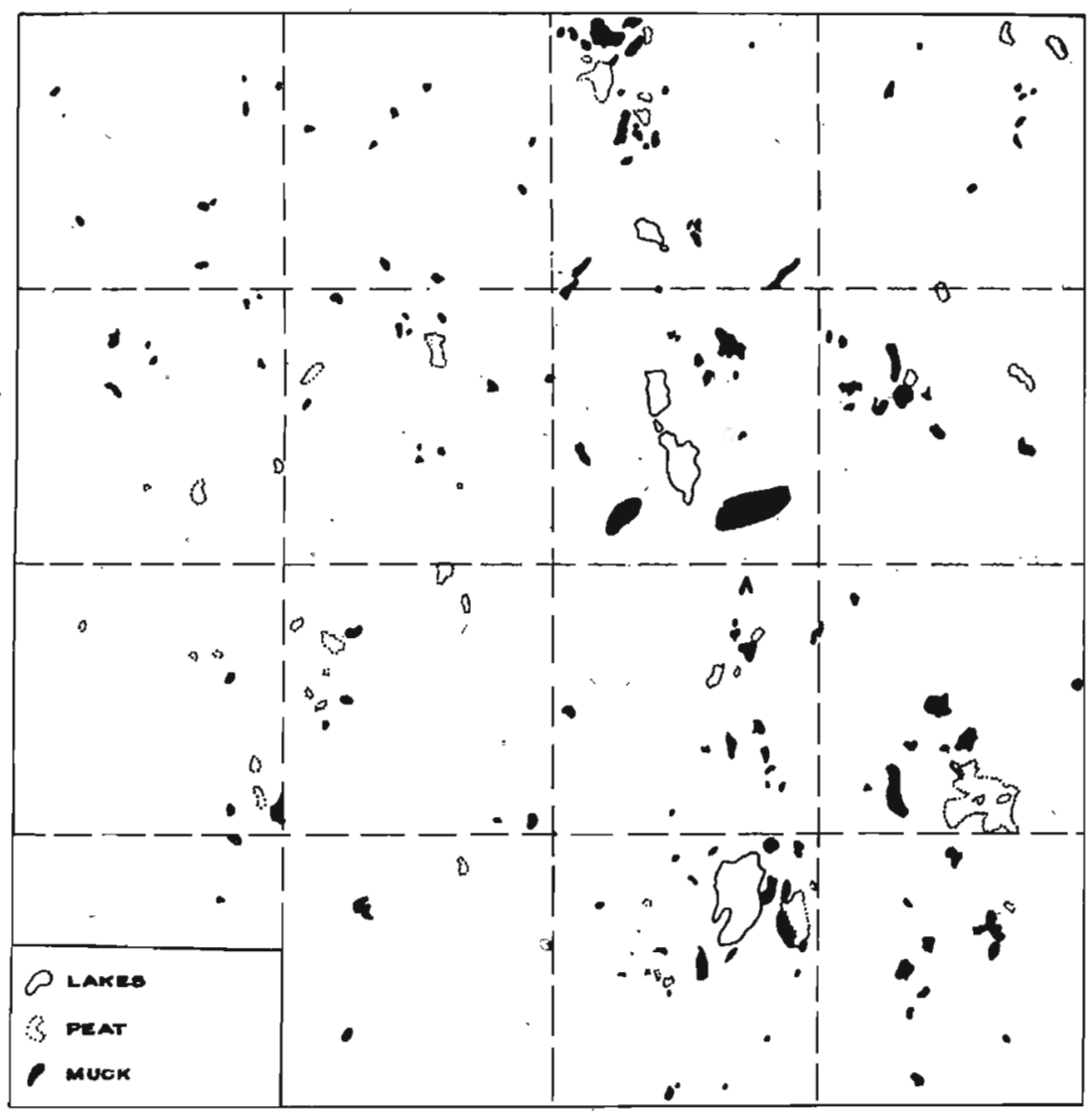

Figure 75. Sketch map of Wright County showing pent, muck and lake areas on the Mankato drift plain. 


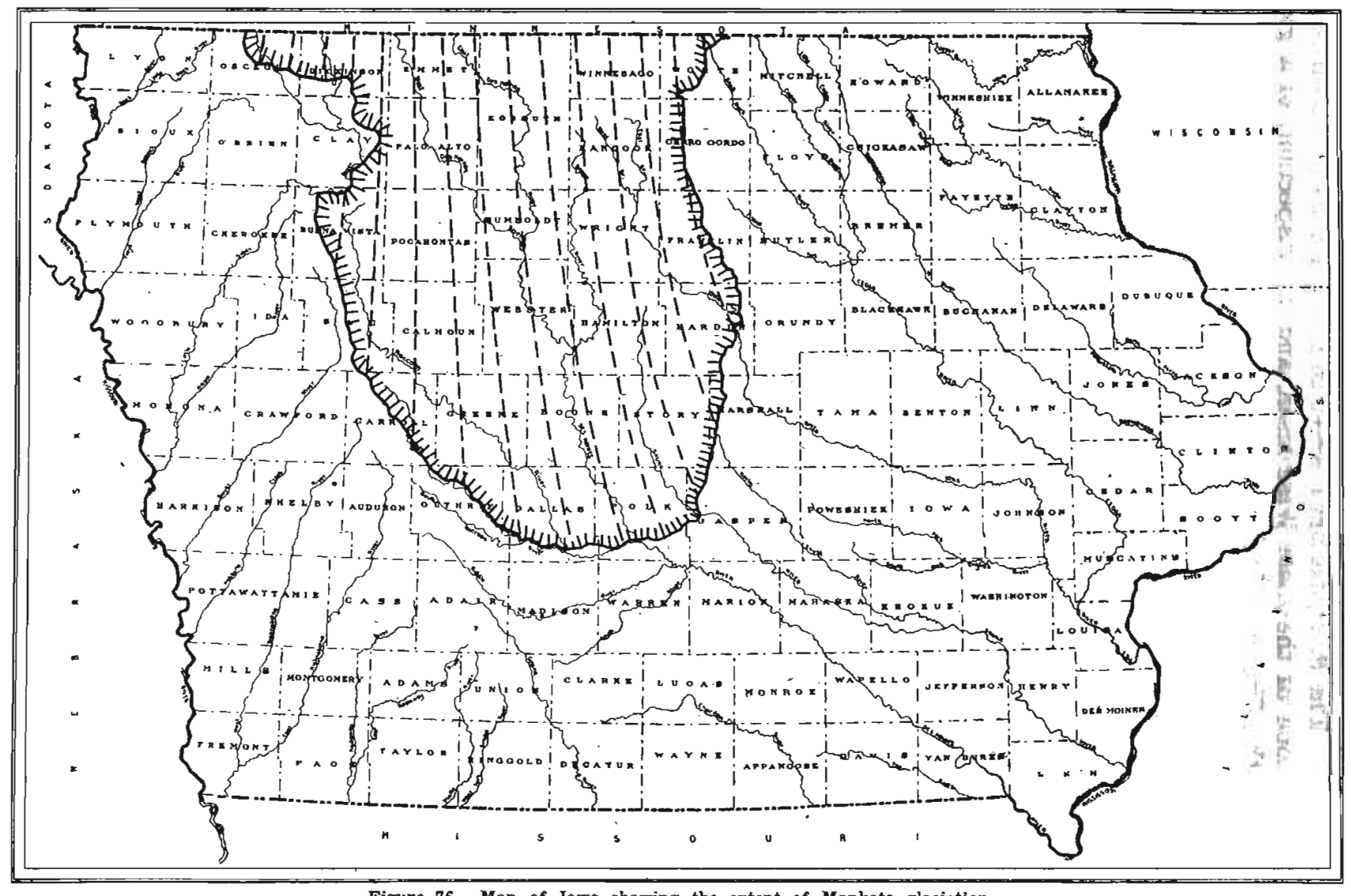


The Mankato drift lobe in Iowa is bounded on both sides along the northern area of the state by Iowan drift. Lateral and terminal moraines quite sharply delimit the Mankato from the gently rolling, drift-mantled erosional Iowan topography of northeastern Iowa, as well as from the Kansan-like Iowan topography on the west. The Mankato lobe spread deeper into the state than did the Iowan, overlapping the Iowan and extending out onto the Kansan drift.

\section{Origin of the Drift}

The Mankato drift is typical unconsolidated glacial material, composed principally of light colored oxidized till and bluish unoxidized till. Outwash sand and gravel deposits occur around the periphery of the lobe and to some extent on the till surface, having been deposited by streams flowing outward from the retreating glacier.

The drift materials were derived from regions to the north of Iowa and from the incorporation of local material by the Mankato ice. The Mankato lobe in Iowa is a tongue of a continental ice mass originating from the Keewatin ice center to the west of Hudson Bay in Canada. In its extension into Iowa the ice moved over bedrock and former drift surfaces, bringing into Iowa materials gouged directly from bedrock, and materials which had already been glacially transported perhaps several times 'by former glaciers. Within the state the glacier overrode a surface variously composed of Peorian loess, Iowan drift and Kansan drift. In places, the Peorian loess surface beneath the Mankato till shows plowing action and indicates some loess incorporation into the till. Such an occurrence is prominent in the Mitchellville cut, located in the NE1/4 sec. 15, Franklin Township, (T. 80 N., R. 22 W.), Polk County, and previously described on pages 169 to 171 of this report. The section shows a considerable amount of Peorian loess intermixed with the thin Mankato till. However, good sections showing the contact of the Mankato drift with underlying materials are rare due to the flat character of the topography and the consequent lack of deep railroad and highway cuts.

Contrary to the theoretical possibility that the materials of this last of the known North American glacial advances would be so largely composed of rehandled surface drift materials that it would reflect unusual weathering, the till is fresh and unaltered 
except for about $2 \frac{1}{2}$ feet of the upper part which has been leached since the Mankato retreat. Some crumbly boulders are found in the fresh till, and these may well have lain at or near the surface of a former drift sheet, but their percentage is not such as to contrast markedly with similar occurrences in the older drifts.

\section{Changes in the Drift}

The Mankato drift materials are so recent in deposition that physical and chemical processes of weathering and alteration have been able to change the original till character only slightly. In the judgment of many glacial geologists, the Recent, or time since the retreat of the last glacier is but the beginning of conditions similar to previous interglacial ages, and it is considered probable that the present moment of geologic time is a stage in the grasual recovery from glacial conditions and just antecedent to the mild, comparatively stable interval of a typical interglacial age. There are convincing arguments in support of this view of our present position in the Pleistocene period.

Principally through the work of DeGeer and Antevs on Pleistocene geochronology, estimates as to the antiquity of the last continental glacier in Europe and North America have been generally accepted as about 25,000 years. Geologically speaking, this interval is extremeiy short, and in comparison with estimates of other intervals of weathering during the Pleistocene ${ }^{116}$ it becomes apparent that the effects of weathering agencies, if such agencies react with similar rapidity under similar climatic and topographic conditions, cannot have produced any changes in Mankato till comparable in degree to the changes previously discussed in relation to the older drifts. That this generalization is substantiated in the field is not difficult to demonstrate. Erosion has as yet scarcely touched the depositional forms of the recently deposited Mankato drift. Oxidation, always the first agent to attack and alter the physical appearance of fresh, bluish till, has changed the till to a light gray-buff color to. various depths, but nowhere have the materials acquired the old, rusted and iron-cemented appearance of the tills and gravels which have been subjected to much greater periods of oxidation. Leaching and other chemical processes which were active for long enough intervals to have caused the formation of an inactive residuum or gumbotil in places on the

\footnotetext{
110Kay, G. F., Classification and duration of the Pleistocene period: Geol. Soc. America Bull. vol. 42, DD. $425-466,1981$.
} 
three oldest tills, have only removed the carbonates from the Mankato till for a depth of about 30 inches on the average. No gumbotil has been formed and presumably will not be formed until leaching and other chemical changes have taken place to a depth somewhat greater than that on the Iowan drift, which averages about $5 \frac{1}{2}$ feet. The profile of weathering as found on the three oldest drifts is in a mast immature stage on the Mankato till.

\section{Typical Sections of the Mankato Drift}

The generally level character of the Mankato drift surface tends toward scarcity of cuts along the roads and toward shallowness of those that need to be made. Satisfactory exposures of drift along the stream courses also are rather uncommon. However, a number of cuts over the Late Wisconsin area show several feet of Mankato till; some extend into the underlying Iowan loess and a few even reach below into the subjacent drift sheet. In each case this drift was shown to be Kansan or older, either by.its geographic location, by its character, or by the presence of its overlying gumbotil.

Mankato Till Over Loess and Pre-Iowan Till

Naturally the best exposures showing older till under Mankato are near the margin of the later till sheet. One very good section of this nature was exposed in 1920 during the cutting to a lower grade of West Fifth Street in Des Moines. ${ }^{117}$ This section showed:

"5. Till, Wisconsin, (Mankato), oxidized to brownish clay, bouldery, many limestone.

Feet Inches

4. Loess, Iowan, calcareous, chiefly yellow, locally gray in upper part, the latter marked at its base by a ferruginous band. Yellow phase fossiliferous in places, red 'pipe-stems' in gray phase. Maximum thickness

3. Till, Kansan, leached, red brown, sticky, in most places pebbles few and very small, when dry hard with starchy fracture.

6

2. Till, Kansan, leached, oxidized to yellowish, boulders, some red fresh granites..

1. Shale, Des Moines, variegated.;

Lees states:

"In the vicinity of Crocker Street there are in the upper portion of the loess several small sand lenses about four feet long and six inches thick. They ... are surrounded by the gray loess except where they rise to the surface of this stratum and come in contact with the overlying till. These lenses were stated by Keyes to be largely volcanic ash."

${ }^{117}$ Lees, James H., Some Pleistocene exposures in Des Moines: Iowa Acad. Sci., vol. 28, p. $60,1921$.

insKeyes, Charles R., Discovery of voleanic ash in Iowa: Iowa Acad. Sci., vol. 28, p. 49, 1921. 
A smaller section with similar range was seen in the bluff forming the north wall of Des Moines valley south of the State House in Des Moines. The succession here observed at the mouth of a ravine was:

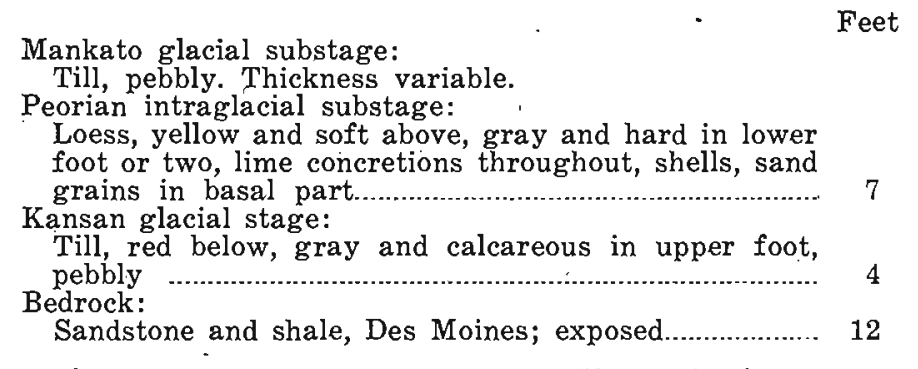

The series of cuts west of Rhodes (fig. 77), in Marshall and Story Counties, on the Omaha line of the Chicago, Milwaukee, St. Paul and Pacific Railroad, showing Mankato till over loess and this in turn over Kansan gumbotil and till has been already described by Kay and Apfel and by Alden and Leighton. ${ }^{110}$ These cuts probably give the best exposures of this kind that have ever been found in the state: They are just within the Late Wisconsin margin and represent the work of the Mankato ice at its extreme advance. Another section that is well within the limits of the Mankato drift sheet is on the south bank of Raccoon River in the N1/2 sec. 27, Grant Township, (T. 83 N., R. 30 W.), in Greene County. When this section was examined it showed good exposures from top to bottom of the high bluff. The section as examined included the following members:

Mankato glacial substáge:

Feet Inches

Till, oxidized and leached, yellow, some sand streaks, in places breaking into great prismatic blocks............ Till, oxidized and unleached, yellowish gray, with some large gravel boulders..

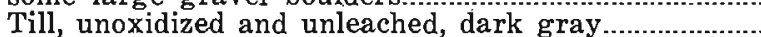

Peorian intraglacial substage:

Loess, gray or brown above, becoming yellow on exposure, unleached, but no fossils or concretions. Some shows joint structure and ru'st-red color on joint faces. Lower part is blue, abundantly fossiliferous locally. Loess rises 40 feet above river and is sharply marked from the Mảnkato till

Buchanan interval:

Gravel, in places, rusty, red and yellow, some layers fine sand, some sand and silt, some coarse gravel;

110Kay, G. F., and Apfel, E. T., The pre-Illinoian Pleistocene geology of Iowa: Iowa Geol. Survey, vol. 34, p. 233,1929 .

Alden, Wm. C., and Leighton, M. M., The lowan drift, a review of the evidences of the Iowan stage of glaciation: Iowa Geol. Survey, vol. 26, p. 161, 1917. 


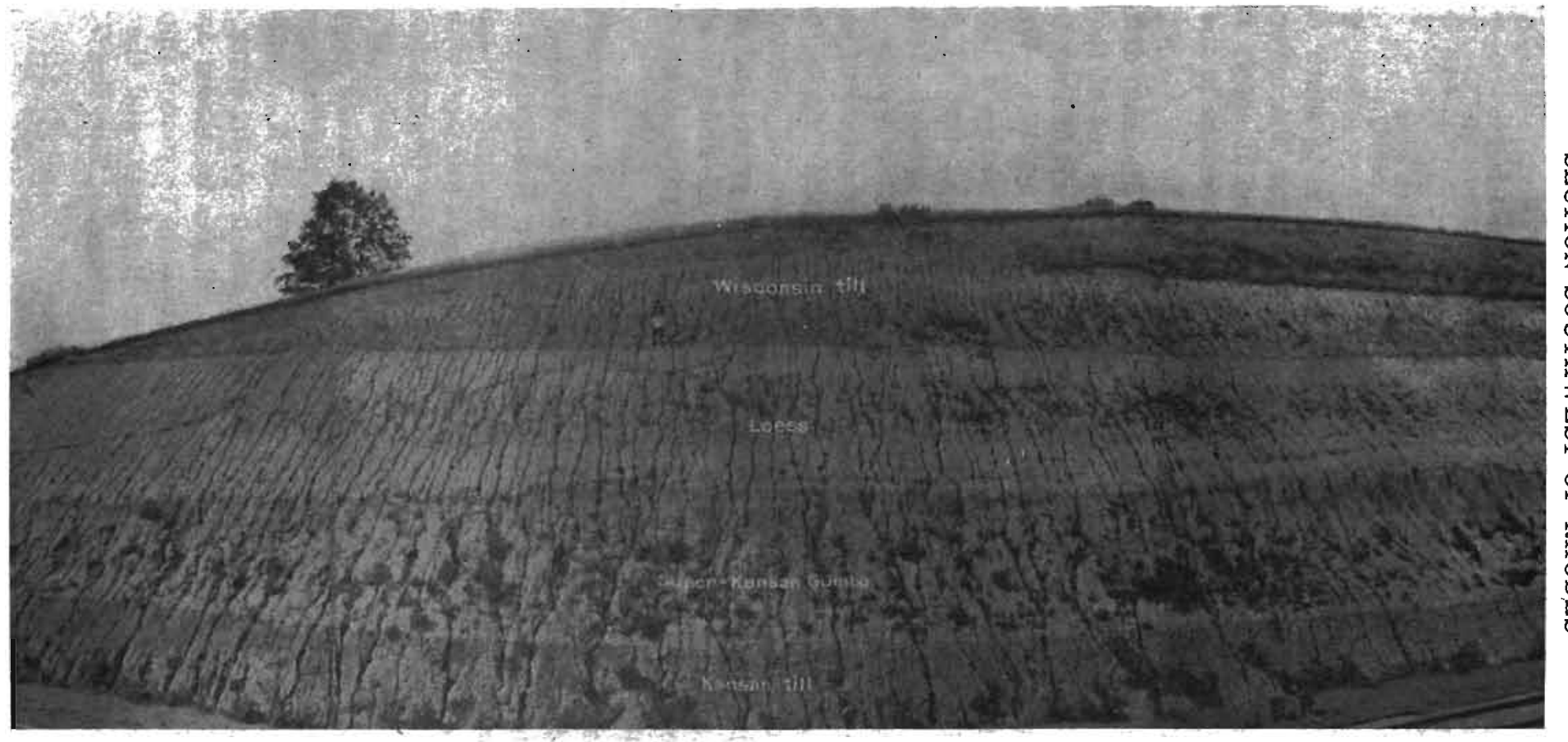

Figure 77. Wisconsin till of Mankato age overlying Peorian loess in Chicago, Mịlwaukee and St. Paul Railway cut southwest of Rhodes, Marshall County. 


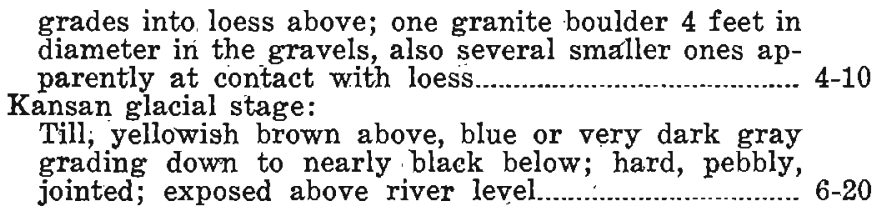

The lower till is classed as Kansan because it is south of the probable margin of the Iowan. It is darker than the lower part of the Mankato as exposed above the loess, and it shows rather more definite jointing. This is one of the best sections in the area of the Late Wisconsin drift.

Several other exposures are known in which Mankato drift lies on much older materials. One of these is in the pit of the Fort Dodge Brick and Tile Company in the northern part of Fort Dodge, sec. 19, Wahkonsa Township, (T. 89 N., R. 28 W.), Webster County. It shows above the "Coal Measures" shales a layer of gray gumbotil, then gray Mankato till, then 12 feet of yellow Mankato till, and at the surface 3 feet of gray gravel. Again, at the highway bridge over the West Fork of Des Moines River about a mile south of Bradgate, in the northwest corner of sec. 17, Avery Township, (T. 92 N., R. 30 W.), Humboldt County, undercutting and road grading have exposed $2 \theta$ feet of yellow, very pebbly Mankato till, 5 feet of rather fine fresh gravel and 20 feet of drab, sparsely pebbly drift, the-upper part of which is altered to gumbotil. The gumbotil is shown again 100 yards down stream and about 10 feet above the water.

Since the Kansan gumbotil is thought to be absent north of Crawford County, while the Nebraskan gumbotil is known to be present in Cherokee County, 55 miles west of Bradgate, it seems most probable that the Bradgate outcrops of gumbotil and till are Nebraskan in age. Their altitude is about 1100 feet, while the altitude of the Nebraskan gumbotil at Cherokee is 1235 feet and that at Coon Rapids, 65 miles south, is 1180 . On the other hand, the Kansan gumbotil at its farthest known northward exposure, along the Chicago and North Western Railway track in the northwest corner of sec. 9 , Stockholm Township, (T. 85 N., R. 38 W.), Crawford County, lies 1400 , feet above sea level. In other parts of Crawford County the Kansan gumbotil has been seen as high as 1485 feet above sea level. These facts seem to render improbable a Kansan age for this gumbotil at Bradgate, and the same argument applies to that seen at Fort Dodge. This lies 75 feet 
above the river, but its elevation is only about 1050 feet above sea level.

One other good section showing drift materials ranging in age from late Wisconsin to Kansan was opened in the course of road grading on State highway 64 (formerly 7) west of Panora at the middle of the north line of sec. 6, Cass Township, (T. 80 N., R. 30 W.), Guthrie County. (See fig. 53, p. 172). Along the slope of the valley wall the cuts showed this succession:

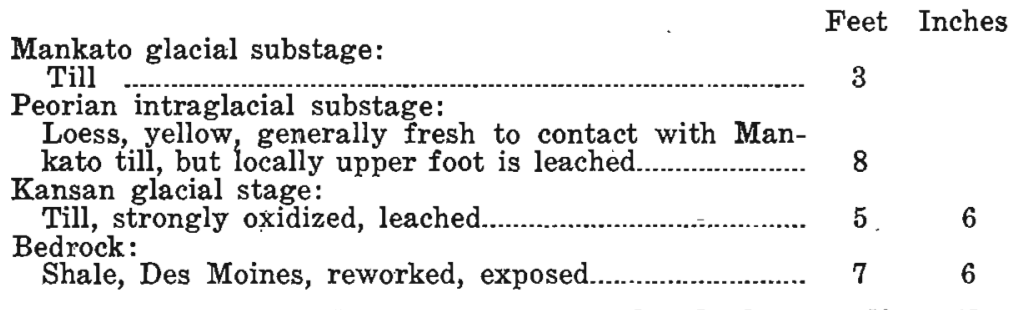

In places Mankato gravel, rusty but unleached, overlies the loess. At the upland, Kansan gumbotil is on the Kansan till. This cut is just at the margin of the Mankato drift sheet and shows the westernmost push of the late Wisconsin ice for this locality.

One of the famous cuts of an earlier, day was that of the Chicago Great Westerm Railway just northeast of Carroll, in sec. 19, Grant Township, (T. 84 N., R. 34 W.), Carroll County. This exposure showed:

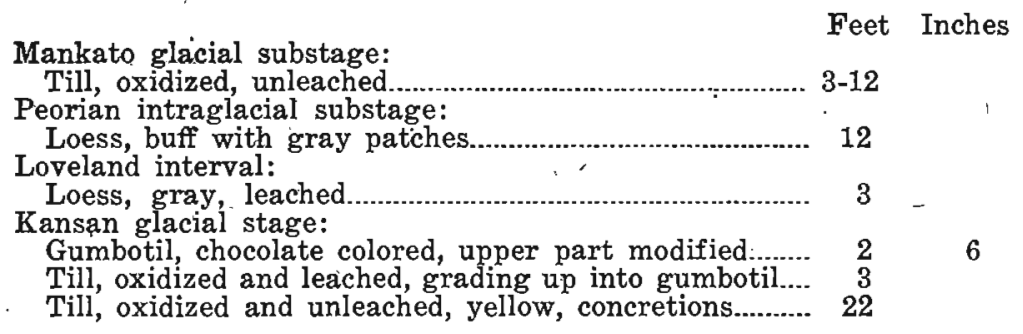

The elevation of the gumbotil is 1275 feet above sea level.

Another exposure of Mankato till and Peorian loess over Kansan gumbotil was seen in Dallas County, in the $N W 1 / 4$ sec. 4, Colfax Township, (T. 79 N., R. 28 W.).

A good section, from which, however, the Kansan gumbotil had been removed, is in southern Hardin County, in the SE1/4, sec. 6, Providence Township, (T. 86 N., R. 20 W.). It showed: 
Mankato glacial substage:

Feet. Inches

Till to the upland, over.

20

Peorian intraglacial substage:

Loess, calcareous; approximately $\ldots$

Kansan glacial stage:

Till, highly oxidized, to base of slope, approximately.... 10

This series of sections shows that at least in the southern part of its extent, the Mankato ice sheet, while it overrode the Peorian loess, did not greatly disturb it. This loess must have been leached through not much more than 2 to 3 feet of its thickness, on the average, and in most cases this leached part, together with an unknown amount of unleached loess was scraped off by the advancing ice.

\section{Mankato Till over Peorian Loess}

In a few cases the Mankato till is thin enough so that in the making of road grades it was cut away and the loess that underlies it was exposed but not entirely penetrated so that the underlying till could be seen. One of these cases is a road cut in the NW $1 / 4$ sec. 12, Boyer Valley Township, (T, 88 N., R. 36 W.), in Sac County, about 2 miles east of Early, on the east wall of Indian Creek Valley. Here the Mankato till is about 12 feet thick and is fresh within $2 \frac{1}{2}$ feet of the top. It lies on loess, which is plowed up to some extent. This loess is yellow. but unleached and carries concretions. Evidently the late Wisconsin ice or waters cut away the leached loess and mingled gravel and fresh Peorian loess in the lower part of the Mankato till sheet. The thickness of the loess is unknown as only about 2 feet is exposed above the slump.

A series of sections in glacial materials on Capitol Hill in Des Moines that was, described in 1882 by McGee and Call ${ }^{120}$ made this locality famous as helping to demonstrate the plurality of the ice sheets. While these sections did not actually show two drifts they did show a thick body of loess underneath Mankato till. When the grade of East Court Avenue was lowered through the State House grounds in 1915 the locations of McGee and Call's sections were cut through and abundant opportunity was given for extensive study of the beds capping the hill. Several sections were carefully studied by Lees ${ }^{121}$ and one of the most typical is given here:

120McGee, W J, and Call, R. E., On the loess and associated deposits of Des Moines : Am. Jour. Sci., vol. 24, pp. 202-223, 1882 .

12iLees, J. H., The Pleistocene of Capitol Hill: Iowa Acad. Sci., vol. 28, pD. 167-172, 1916. 


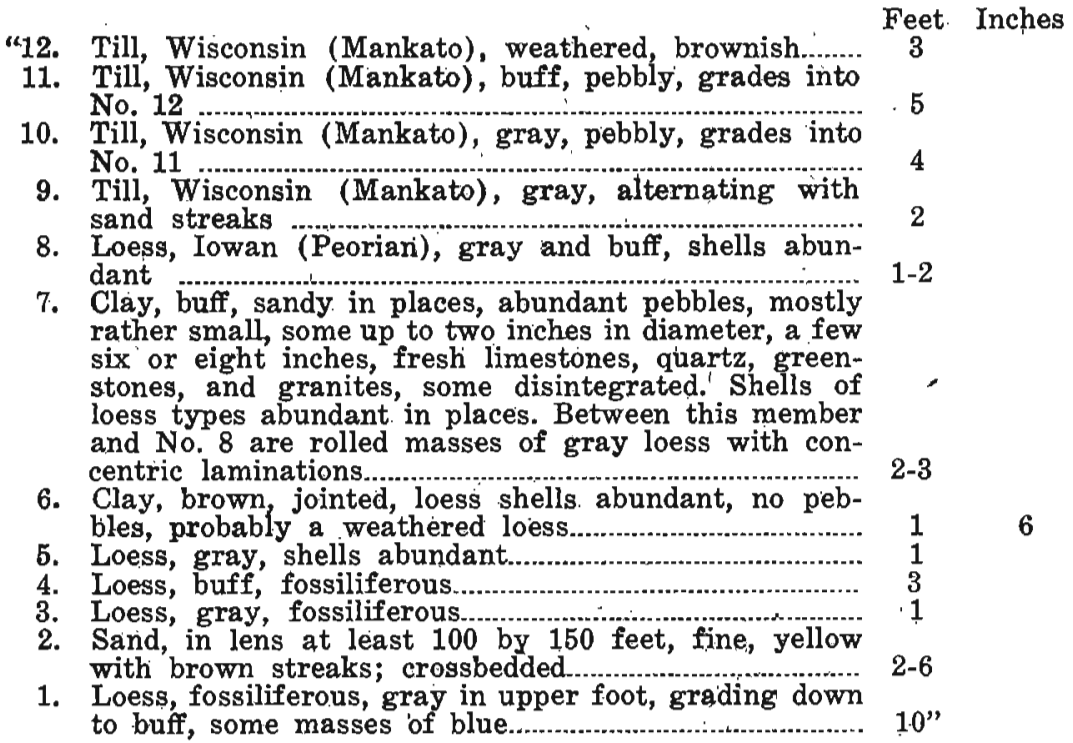

The total thickness of the loess must be about 20 feet. Below it were exposed geest, residual from the Des Moines shales, and about 15 feet of the unaltered shales. N' pre-loessial till was seen in any of the exposures. The clay; no. 7, was remarkable in' being so abundantly, fossiliferous and at the same time pebblebearing. It seems to have been a mixture of till and loess, probably laid by waters from the ice. It is to be noted that this exposure is at the extreme edge of the late Wisconsin drift sheet.

Gray Peorian loess was reached also three blocks north of these cuts, in the excavation through late Wisconsin till made in 1920 for a heating plant tunnel to the State House. Similar loess was found in the excavation for the new East High School building four blocks farther iorth.

\section{Exposures Showing Only Mankato Till or Gravel}

Naturally there are, distributed over the area of the Mankato drift sheet, numerous shallow exposures of late Wisconsin materials, either till or gravels or both. These differ merely to a minor degree in character of material and depth of leaching, and their general accordance testifies to the uniform conditions to which they have been subjected and the uniform results attained.

A series of sections in Dallas County seems to show the effect of the character of material on the range of leaching in the till. 
An opening in the SE $1 / 4$ sec. 5, Walnut Township, (T. 79 N., R. 26 W.), was made to obtain gravel. It exposed:

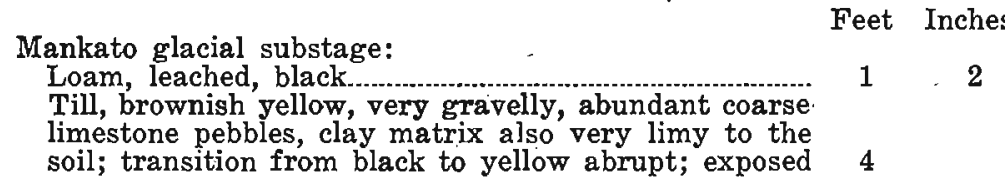

The slopes are very gentle and suggest that very little erosian can have occurred. The section seems to show that where till has much limestone it is leached very slowly, and hence this process has not gone very far downward.

Another section was observed on the north side of the NE1/4 sec. 2, Linn Township, (T. 79 N., R. 29 W.). It consisted of :

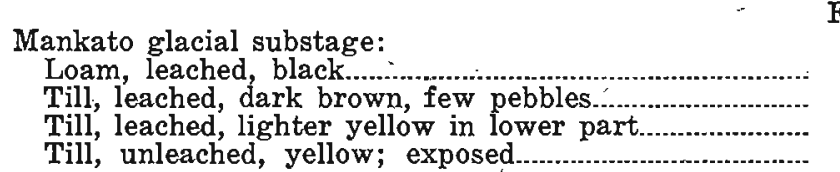

Loam leached black

Till, leached, dark brown, few pebbles...........................

Till, unleached, yellow; exposed

Feet Inches

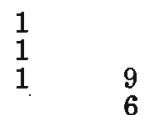

This , cut is at the upland where erosion must have been very slight. The till is somewhat sandy.

- The third section in this series is a road cut in the NE $1 / 4$ sec. 7 , (T. 79 N., R. 26 W.), and it showed:

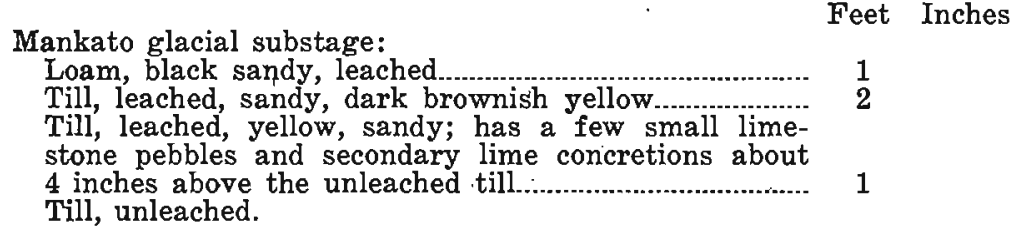

This cut also is near the upland and the slopes are very gentle. The leaching of 4 feet is somewhat greater than normal and may be due to the sandy and porous nature of the till, which would permit free percolation and relatively rapid leaching. A number of other sections in this part of the state show similar features.

A road section in the $\mathrm{SE} 1 / 4$ sec. 33, Fremont Township, (T. 89 N., R. 26 W.), Hamilton County, seems to show the effect of composition and texture on weathering. It is as follows :

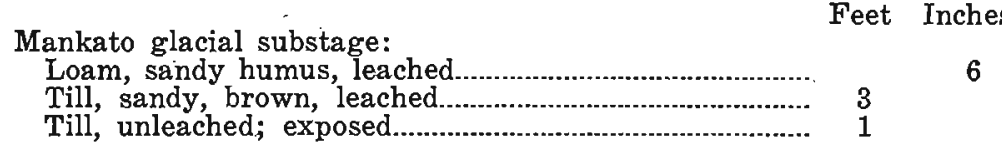

This exposure is out on the level Mankato plain and should be typical for the type of deposit represented. 
Two sections in Calhoun County are of interest as showing similarity of ehange in different materials. The first exposure is in the SE1/4 sec. 4, Williams Township, (T. 89 N., R. 34 W.). It is a pit in Mankato upland gravels and reveals :

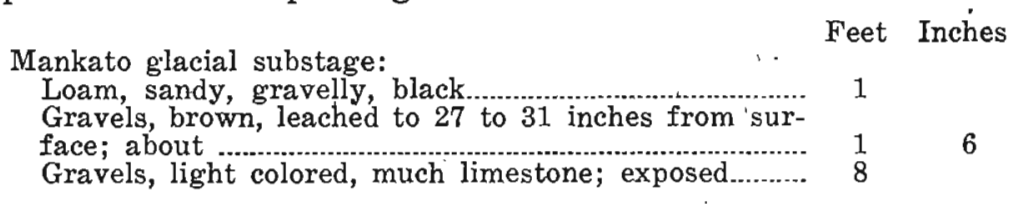

The other section is a road cut in the $\mathrm{SW}^{1 / 4}$ sec. 34, Garfield Township, (T. 88 N., R. 34 W.), and is in normal till. It is as follows :

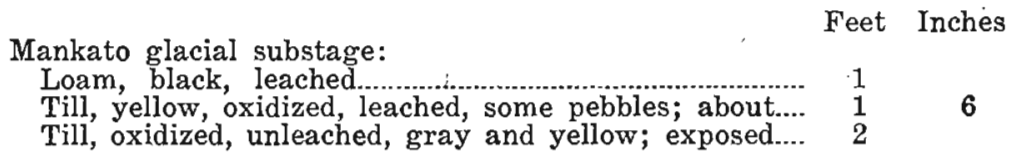

In these cases the very limy gravels and the normal limy clay have suffered leaching to about the same depth. Both exposures are at the upland and have been subjected to similar conditions.

Several roadside cuts within a mile south of Eagle Grove in Wright County show till which is leached from 3 feet 4 inches in normal till to 5 feet in sandy till, and a cut in the southwest environs of Fonda, (T. 90 N., R. 34 W.), in Pocahontas County, shows what seems to be more nearly the average of $2 \frac{1}{2}$ feet of leached material. This exposure shows normal compact pebbly clay till which is leached 31 inches but still contains pebbles nearly up to the sod. This locality is on the upland where there can have been neither erosion nor deposition since the drift was brought in.

A gravel pit in the east part of Mason City, Mason Township, (T. 96 N., R. 20 W.), Cerro Gordo County, seems to bear out the view that gravels containing much limestone do not leach so rapidly as do clays with very little lime, but with much siliceous sand, despite the greater porosity of the gravel. This pit shows a sandy, pebbly, leached loam with a thickness of 1 foot 3 inches, below which are fresh gravels filled with limestone pebbles. Similar features are shown in outwash gravels in the southeast corner of sec. 17, and the north part of sec. 28, Kensett Township, (T. 99 N., R. 20 W.), of Worth County. Pits in these gravels show that leaching has progressed to a depth of 2 feet 10 inches and 2 feet 6 inches respectively. A number of road cuts in the northern counties of the late Wisconsin area show a general uniformity in leach- 
ing of soil and till to a depth of about $2 \frac{1}{2}$ feet. A series of such cuts in the SW $1 / 4$ sec. 11, Swan Lake. Township, (T. 99 N., R. 32 W.), Emmett County, shows a range from 2 feet 4 inches to 3 feet 3 inches. Since topographic conditions are similar at all cuts this difference seemingly is attributable to different composition of the till.

Most of the sections in the Mankato area are too shallow to uncover a great thickness of the Mankato till. The following section made along the north wall of the Des Moines River Valley in the SW $1 / 4$ sec. 12, Cresco Township, (T. 95 N., R. 29 .W.), Kossuth County, just south of Algona, shows more Mankato till than is commonly seen:

Mankato glacial substage:

Feet Inches

Loam; sandy, with humus

Till, leached, on surface light brown, at depth brown

to chocolate color, pebbly.

Till, unleached distinctly oxidized, light yellow to yel-

lowish gray on dry slove, yellow to brownish on

fresh surface; cuts readily, not compact...................... 6

Till, unoxidized and unleached, but oxidized along

joints. Inclusions of sand are oxidized. To base of cut 16

(In the oxidized and unleached zone there are inclu-

sions of loess).

Down the slope toward the flood plain very dark un-

oxidized and unleached Mankato till was exposed. The

flood plain is 64 feet below the upland.

\section{Description of the Drift Phases}

\section{Oxidized and Leached Mankato Till}

Under normal, conditions of topographic stability and interglacial weathering processes, a profile of weathering will develop in till materials, the completeness of this profile depending primarily upon the length of time during which the agents of weathering are free to act. Three of the drift sheets in Iowa have been exposed to weathering agents a sufficient length of time to have developed mature profiles of: weathering, with all of the till phases present, differing from one another, only in the degree of depth to which the various phases have been formed.

The Mankato drift is the youngest substage of the last glacial age, and as such has not been exposed to agents of weathering long enough to have acquired a mature profile of weathering. No gumbotil has been formed, and leaching has as yet changed only the upper 30 inches on the average. Oxidation has penetrated to a greater depth than leaching, but the lightness of color of the 
till attests the incompleteness of oxidation of the content of iron compounds in the till.

The topmost phase of the Mankato till, except for occasional areas of peat and humus, is the oxidized and leached phase which except for the Iowan, occurs below gumbotil on the older drifts. This zone is light brown in color, or may be chocolate brown where present day humus material has penetrated. Leaching has removed the carbonates to depths ranging from 2 to 5 feet, with an average depth of $2 \frac{1}{2}$ feet. The till is pebbly to sandy and is not compact.

The clastic texture of the oxidized and leached Mankato till is so much like that of the oxidized and leached Iowan till that a comparison of an average analysis of each shows almost no differences. The analyses of the averages of the two ages of till are more nearly identical than one would expect to find even within two samples of till from either till sheet (fig. 6, p. 34). In the average analysis of the Mankato oxidized and leached till, the maximum percentage of material, about 28 percent, is finer than $1 / 64$ millimeter in diameter. The size grade between $1 / 32$ and $1 / 64$ millimeter in diameter contains about 9 percent or only about 30 percent as much material as the grade below 1/64 millimeter in diameter, and the size grade between $1 / 16$ and 1/32 millimeter in diameter shows an increase to 15 percent or about 50 percent as much as that size grade finer than $1 / 64$ millimeter in diameter. As in the Iowan till, the greatest percentage of the sample is within the size grades between $1 / 2$ and 1/32 millimeter in diameter.

The lithology of the Mankato oxidized and leached till (fig. 78) has only one point of difference of importance from that of the Iowan oxidized and leached till: it is the low percentage of greenstone and the high percentage of granite. All of the other constituents are almost in the same percentages.

Processes of weathering have disintegrated some of the material and solution has rounded some of the grains. The shapes of the grains of all sizes correspond closely with those of the Iowan oxidized and leached till.

\section{Oxidized and Unleached Mankato Till}

The general appearance of the oxidized and unleached Mankato till is so similar to the oxidized and leached phase above that its 
differentiation is dependent upon tests with acid. The transition zone between the leached and unleached zones is indistinct and is

\begin{tabular}{|c|c|c|}
\hline & $\begin{array}{l}\text { ankato Till } \\
\text { Unleached }\end{array}$ & $\begin{array}{c}\text { Mankato T } \\
\text { Leached }\end{array}$ \\
\hline Greenstone .......... . & 19.00 & 36.50 \\
\hline Greenstone Schist & 1.00 & 2.00 \\
\hline Granite & 21.00 & 40.00 \\
\hline $\begin{array}{l}\text { Diorite } \\
\text { Syenite }\end{array}$ & 1.00 & 2.00 \\
\hline Porphyry & 3.00 & 6.00 \\
\hline Other Crystallines & 3.00 & 6.00 \\
\hline Quartzite & 1.00 & 2.00 \\
\hline Quartz & 1.00 & 2.00 \\
\hline Sandstone & 1.00 & 2.00 \\
\hline Limestone & 47.00 & \\
\hline Chert & 1.00 & 2.00 \\
\hline $\begin{array}{l}\text { Shale } \\
\text { Clay Ironstone }\end{array}$ & & \\
\hline Hematite and Jasper & & \\
\hline
\end{tabular}

Figure 78. Lithological analysis of leached and unleached Mankato till.

an irregular thin zone of downward penetrating fingers of till between blocks of unleached till which have the appearance of included masses in the base of the overlying phase.

In color, the oxidized and unleached till is light yellow to yellowish gray on a dry slope, yellow to brownish on fresh surfaces. It breaks readily into irregularly shaped fragments and is not compact.

The clastic texture of the Mankato oxidized and unleached till is so nearly identical to that of the clastic texture of the oxidized and unleached Iowan till that it is impossible to point out differences. The minimum size grade as shown by the average mechanical analyses of figure 6 , page 34 , is below $1 / 64$ millimeter in diameter. Although it varies in different samples, the average is about 25 percent. The next coarser size grade, 1/32 to 1/64 millimeter in diameter, has an average of only 7 percent. In each of the separate samples, as well as the average, this was followed by an increase in percentage in the $1 / 16$ to $1 / 32$ millimeter size grade, a slight decrease in the $1 / 8$ to $1 / 16$ millimeter size grade, and another small increase in the $1 / 4$ to $1 / 8$ millimeter in diameter size grade. Above 1/8 millimeter in diameter there is no uniformity within the different samples.

The lithology of the oxidized and unleached till is almost identical with that of the oxidized and leached Mankato till except that it contains almost 50 percent limestone (fig. 78). The oxidized and unleached till has been altered from the original till only by 
the oxidation of some of the iron compounds. This oxidation involved practically no disruption or solution so the shapes of the grains of all sizes are unchanged and show no rounding by solution. Some of the pebbles show marks on the surface formed during transportation by the ice.

\section{Unoxidized and Unleached Mankato Till}

The basal phase of Mankato till, the unoxidized and unleached zone, is rarely seen due to the scarcity of deep cuts in the Mankato drift plain where the drift has a greater depth than has been penetrated by oxidation processes. As in the transition zone between the two phases above, the change from oxidized to unoxidized till is irregular, appearing as interfingering zones, more or less determined as to position by the major jointing of the till.

The color of the unoxidized and unleached Mankato till is dark gray except along the joint lines, which are lined in yellow from incipient oxidation. The unoxidized till is highly calcareous and breaks into irregularly shaped fragments. Occasional inclusions of sand are oxidized.

The unoxidized and unleached Mankato till has an average clastic texture almost identical to that of the unoxidized and unleached Iowan till. In no part of the analyses is there a difference of more than 4 percent within any one size grade; (fig. 6, p. 34). A comparison of the unoxidized and unleached with the oxidized and unleached Mankato till (fig. 6) shows that there is no evidence of weathering and disruption within the oxidized and unleached till which would result in an increase in the percentages of the finer size grades.

The lithology of the unoxidized and unleached till is the same as that of the oxidized and unleached till, which bears out the above statement that there has been no appreciable amount of weathering within the oxidized and unleached material, for the rocks of the unoxidized and unleached till have not been subjected to alteration and represent original material.

The shapes of the grains in the unoxidized and unleached till are the same as those in the oxidized and unleached till for neither has been altered by disruption or solution, but represents the shapes of the original material at the time of glacial deposition. 


\section{The Mankato Gravels}

Gravels of two types are found related to the Mankato drift. As the ice sheet melted, masses of gravel were deposited within and on the till as irregular pockets and lenses, and as kame-like knobs on the till surface. This type of gravel is intimately associated with the till, being so related to till material as to preclude the deposition of the bodies of gravel apart from that of the till. The second type of Mankato gravel was deposited as outwash in the valleys in front of the ice margin, and may be found beyond the border of greatest extension of the ice sheet, or in the valleys on the Mankato drift surface which carried the glacial flow from the receding glacier. These two types of gravel have been studied and described by Kay and Miller. ${ }^{122}$

\section{The Mankato Upland Gravel}

The Mankato upland gravel is found predominantly in the morainic areas of the drift sheet. Most of the exposures occur in the morainic complex on both the east and west limits of the lobe, but are not common along the southern terminus where no distinct terminal moraine is evident. Deposits within the interior of the drift region are related to recessional morainic trends. The location of known upland gravel deposits is shown in figure 79. Reference to the Mankato morainic system, shown in figure 86 on page 239 of this report will demonstrate the relation of the upland gravel deposits to the topographic morainic features.

In general the gravels show wide variation in oxidation, cementation, structure and size range. The color of the gravel ranges from gray unoxidized gravel to the dark reddish-brown color of highly oxidized iron-cemented gravel. Some thin layers and seams are stained black by a coating of manganese dioxide on the grains. Cementation is not common, but in places iron oxide-cemented conglomerates are found. Gravels cemented by lime or manganese dioxide are raire. In structure, the gravel is very irregular, ranging from horizontal beds with well-marked lines of deposition to steeply dipping beds and prominent cross bedding. Clay-balls, lenses, pockets, and boulders are in many places in the usual horizontally bedded gravel. Some parts of exposures may show unstratified and poorly sorted gravel. The size range varies widely. Most of the gravel is smaller than 5 centimeters in diameter, but

1mKay, G F., and Miller, P. T., The Pleistocene gravels of Iowa: Iowa Geol. Survey, vol. 87, pp. 168-196, 1941 . 


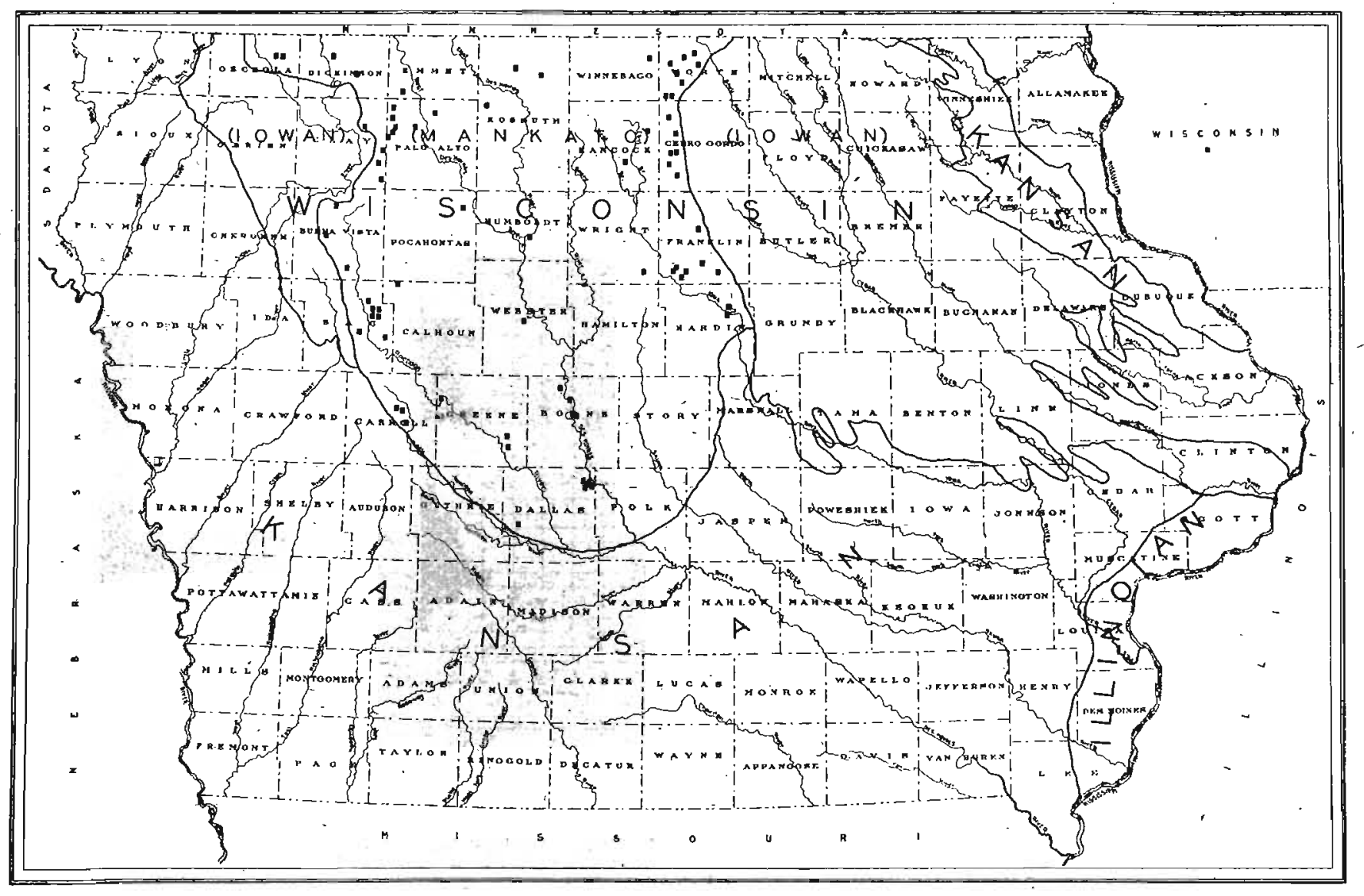

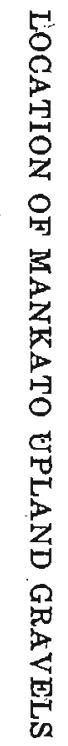

Figure 79 Map of Towa showing locations of Mankato upland gravel deposits. 

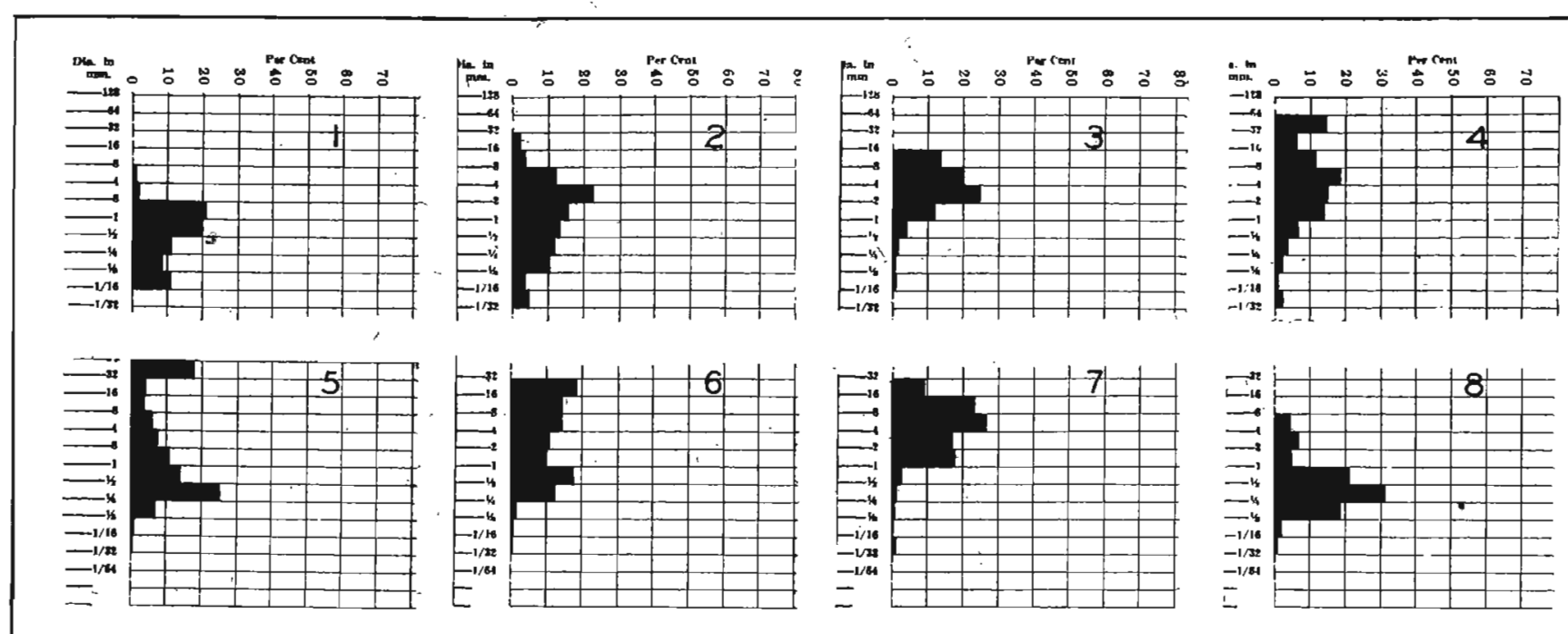

Figure 80. Graphs showing mechanical analyses of Mankato upland gravels. 


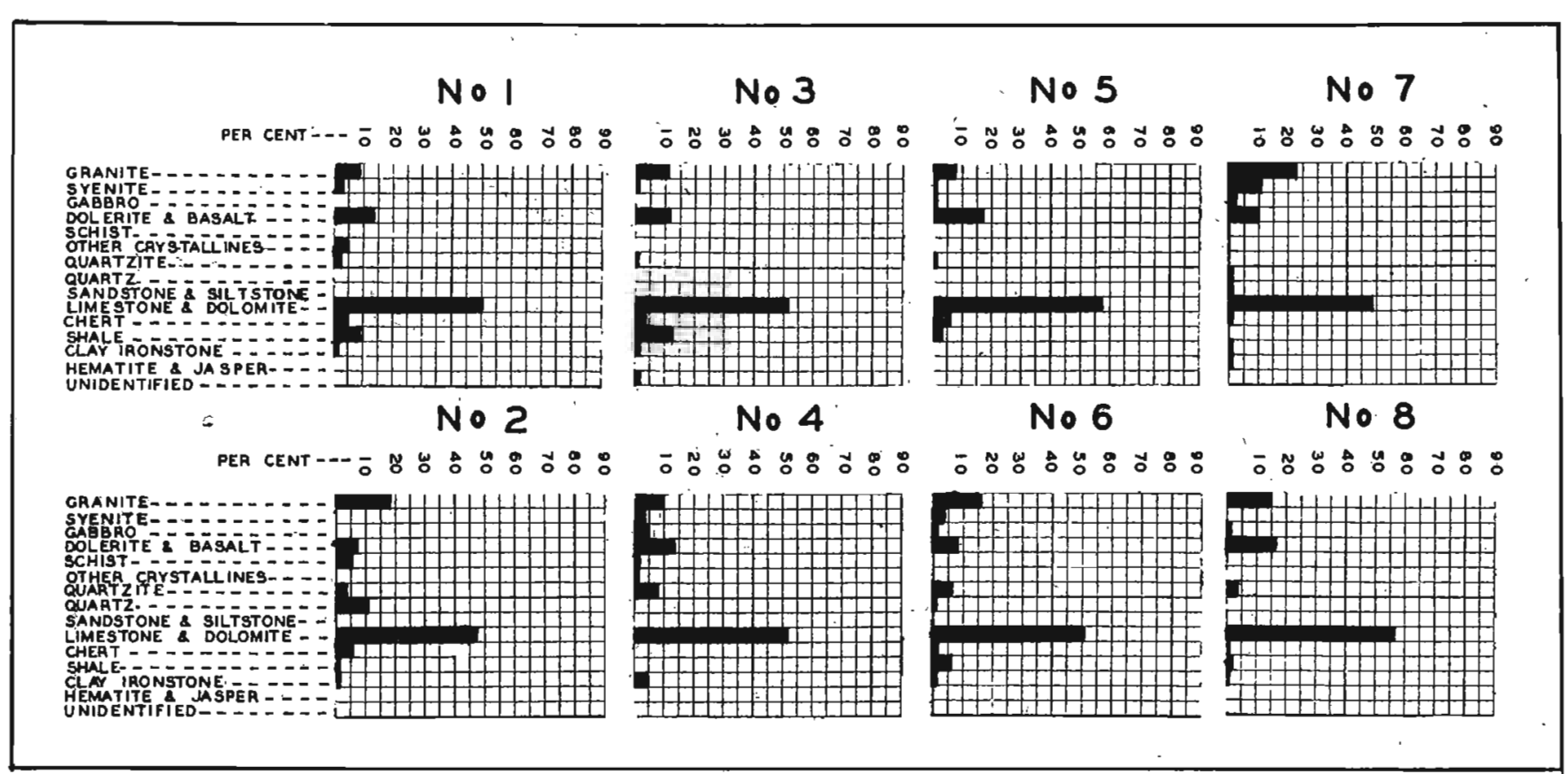
Figure 81. Graphs showing lithological analyses of Mankato upland gravels within the
size range 16 to 32 millimeters in diameter. 
cobbles and boulders as large as 75 centimeters in diameter are common. The percentage of each of the different size grades as found by a mechanical analysis of an average sample from each exposure is given in figure 80 . Lithology of the pebbles between 16 and 32 millimeters in diameter of these same samples is shown in figure 81. The gravel cover is either Mankato till or a thin zone of loess-like silt. Leaching has affected the till materials to a depth of only 2 to 3 feet. Leaching and oxidation of the gravel is dependent upon the thickness of cover and conditions of erosion.

A typical Mankato upland gravel exposure is in the northeastern part of the drift sheet, in Worth County. It is a pit in the $\mathrm{SW} 1 / 4$ sec. 27, Hartland Township, (T. 100 N., R. 21 W.), along the north side of State highway 105, west of Northwood. The gravel is a kame deposit on the Mankatp till surface. This deposit is in the terminal moraine area and is one of many kames which characterize this area of the drift border. The contact at the base of the gravel was not exposed, although the pit extends down more than .4 feet below the general surface of the drift plain.

The gravel is gray and is unoxidized except for the thin gradational zone between the gravel and the thin silty overburden. Leaching has extended into the gravel only where the overburden is less than about $2 \frac{1}{2}$ feet thick. In one part of the pit where the overlying silt is 16 inches thick, leaching of the gravel has occurred to a depth of 1 foot. The general appearance of the gravel is fresh, though some of the coarse crystalline rocks have been disintegrated along the margins by weathering so that crumbling occurs. In size range the pit material varies from fairly fine, well stratified sand and gravel in the middle to coarser, poorly sorted material containing cobbles and boulders in the border areas of the deposit. Most of the gravel is less than 3 centimeters in diameter but cobbles and boulders range from 20 to 40 centimeters In diameter. Size grades and lithology of the constituent pebbles are shown in graph no. 1, in figures 80 and 81 , respectively.

In the SE $1 / 4 \mathrm{SW}^{1 / 4}$ sec. 36 , Hardin Township, (T. 89 N., R. 21 W.), Hardin County, about 6 miles southeast of Iowa Falls, 9 feet of Mankato upland gravel is exposed in a pit excavated in an irregular gravel mass enclosed in the Mankato till. Eighteen inches of pebbly, sandy silt covers the gravel deposit.

The gravel is gray, unoxidized except for the gravel-overburden gradational zone, and leached for about 1 foot below the over- 
burden contact. The deposit is largely gravel finer than $2 \frac{1}{2}$ centimeters in diameter, and coarse sand. Cobbles and boulders are uncommon. Stratification is good and cross bedding and lensing of coarser gravel with sand is common. The mechanical analysis of an average sample' from this exposure is shown in graph no. 3, figure 80. Mineralogical analysis of the size grade from 16 to 32 millimeters in diameter is given in graph no. 3, figure 76 .

Many fine Mankato exposures are in the morainic areas along the northwest boundary of the drift sheet, principally among the knobs and kames of the Ruthven moraine which extends southward from Minnesota into Iowa along the western border of the Mankato drift. Such an exposure is near the town of Ruthvien, near the center of the north line of sec. 21, Highland Township, (T. 96 N., R. 34 W.), Palo Alto County. This exposure is in the morainal region but is on the flat upland.

The material is largely sand and fine gravel, boulders being rare and found only in the base of the pit. The section of this exposure is as follows:

Mankato glacial substage:

Feet Inches

Overburden; loess-like silt containing only an occasional pebble; leached, colored chocolate brown by iron oxide and humus, unstratified; grades into similar material containing a much greater percentage of pebbles, and lighter brown color from oxidation alone

Gravel: light brown, leached only in the upper part; consists of interbedding of sand and fine gravel. Gravel beds are generally 1 to 2 inches thick and sand beds about 6 inches thick; neither is of uniform thickness over any horizontal distance and they often represent large thin lenses. Cross bedding dipping to-

ward the southwest is present in the sand.-.......
Gravel: - interbedding of coarse and fine material. The coarse material is almost all smaller than 5 centimeters in diameter and only a low percentage is larger than 2 centimeters in diameter; beds of coarse gravel are about 5 inches thick, fairly continuous throughout the exposure horizontal but slightly wavy, Some lens-and-pocket structures; cross bedding is distinct within the finer gravel and sand beds..............

Sandy silt: bed 6 to 10 inches thick, generally continuous but lenses out along the margins; contains no coarse material; beautifully stratified with a fine delicate structure consisting essentially of cross bedding, lens-and-pocket structures.

Gravel and sand: chiefly sand, including fine stringers of fine gravel; structure essentially cross bedding, lenses, and pockets which dip generally, toward the southwest. In the upper 1 foot of this zone the material is chiefly in horizontal beds within which are few irregularities such as cross bedding, lens-and- 


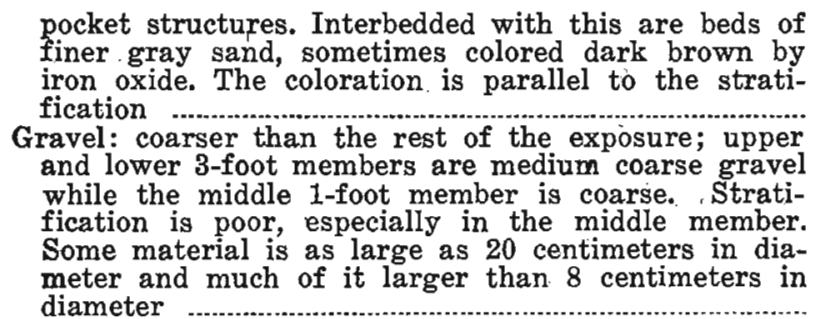

The mechanical analysis of gravel from this section is shown in graph no. 4 , figure 80 , with the rock analysis given in the corresponding graph in figure 81 .

The sections given above are typical of the upland gravels found in and on the Mankato till. The syngenetic relation of such gravels to the till is displayed in numerous sections. These sections show that the upland gravels may be found as "irregular masses which may be either deep within or near the surface of the till, as kame-like hills or esker-like ridges on the surface of the till, as irregular masses included within till of kame-like hills, and as lenses and thin beds interbedded with till."

\section{Mankato Terrace Gravel}

Kay and Miller, ${ }^{123}$ in discussing the Mankato terrace gravel have described only those deposits lying within the borders of the Mankato drift sheet, for while it is possible to differentiate the Mankato gravels from others where their relation to other known materials is definite, the interphasing of gravels of Loveland, Iowan and Mankato age beyond the Mankato drift borders presents a problem in gravel differentiation beyond practical value of solution, and they have been grouped together as "undifferentiated terrace gravels" and will not be discussed here as a definite phase of Mankato materials.

Within the drift borders, Mankato terrace gravel is found in the valley of almost every stream in the region, often filling the stream valleys and forming the present walls of the streams which are now intrenching themselves and forming terraces of the gravel which was deposited by vigorous streams issuing from the retreating Wisconsin glacier.

These glacial valleys may have been pre-Mankato valleys which were not obliterated by Mankato drift and still served as drainage-

IosKay, G. F., and Miller, P. T., The Pleistocene gravels of Iowa: Iowa Geol. Survey, vol, 37, p. 180 , 1941 . 
ways. Others appear to be consequent streams which developed on the uneven surface of the new drift surface. The distribution of the exposed Mankato terrace deposits within the area of the Mankato drift is shown in figure 82.

The gravel forms terraces along most of the streams, ranging in height from flood plain level to as much as 120 feet above present stream level. Most of the terraces, however, are between $\mathbf{2 5}$ and 35 . feet above the stream.

The overburden is sandy to loess-like silt which may or may not contain pebbles. This silt cover may be entirely absent or range to a thickness of 6 feet, but in most places is usually quite thin, so that the gravel cover and the upper several inches of the gravel is usually leached of the carbonate content, though the total depth of leaching is rarely more than 3 to 4 feet. There is generally a gradational zone between the gravel and overburden in which intermixing has occurred. This zone frequently shows more marked oxidation than the silt above or gravel below.

The gravel is highly calcareous except where leached to a shallow depth at the top. Concretions of secondary calcium carbonate are found below the leached zone in some exposures and occasionally cementation occurs. In color the gravel ranges from rusty brown to gray, most deposits being gray to grayish buff. As in the upland gravel, a few of the igneous rocks such as granites, greenstones and schists, are weathered and crumble under slight pressure. The structure is fairly uniform throughout most of the exposures. Stratification is mostly gently dipping with abundant cross bedding. Most of the gravel is finer than 32 millimeters in diameter, although cobbles are encountered which range up to 20 centimeters in diameter. Figure 83 gives the size percentages of several typical exposures. In northeastern Iowa, much of the coarse constituency of the finer well-stratified gravel consists of limestone plates which usually lie with their greatest diameters parallel to the bedding. Mineralogical analyses of samples of the terrace gravel are given in figure 84 .

A representative exposure of Mankato terrace gravel is found in a large gravel pit along the south side of the Iowa River near the southeast corner of Iowa Falls, in the $\mathrm{NE}^{1 / 4}$ sec. 19, Hardin Township, (T. 89 N., R. 20 W.), Hardin County. The terrace level is 50 to 55 feet above the river. The gravel is exposed to a depth ranging from 13 to 18 feet. 


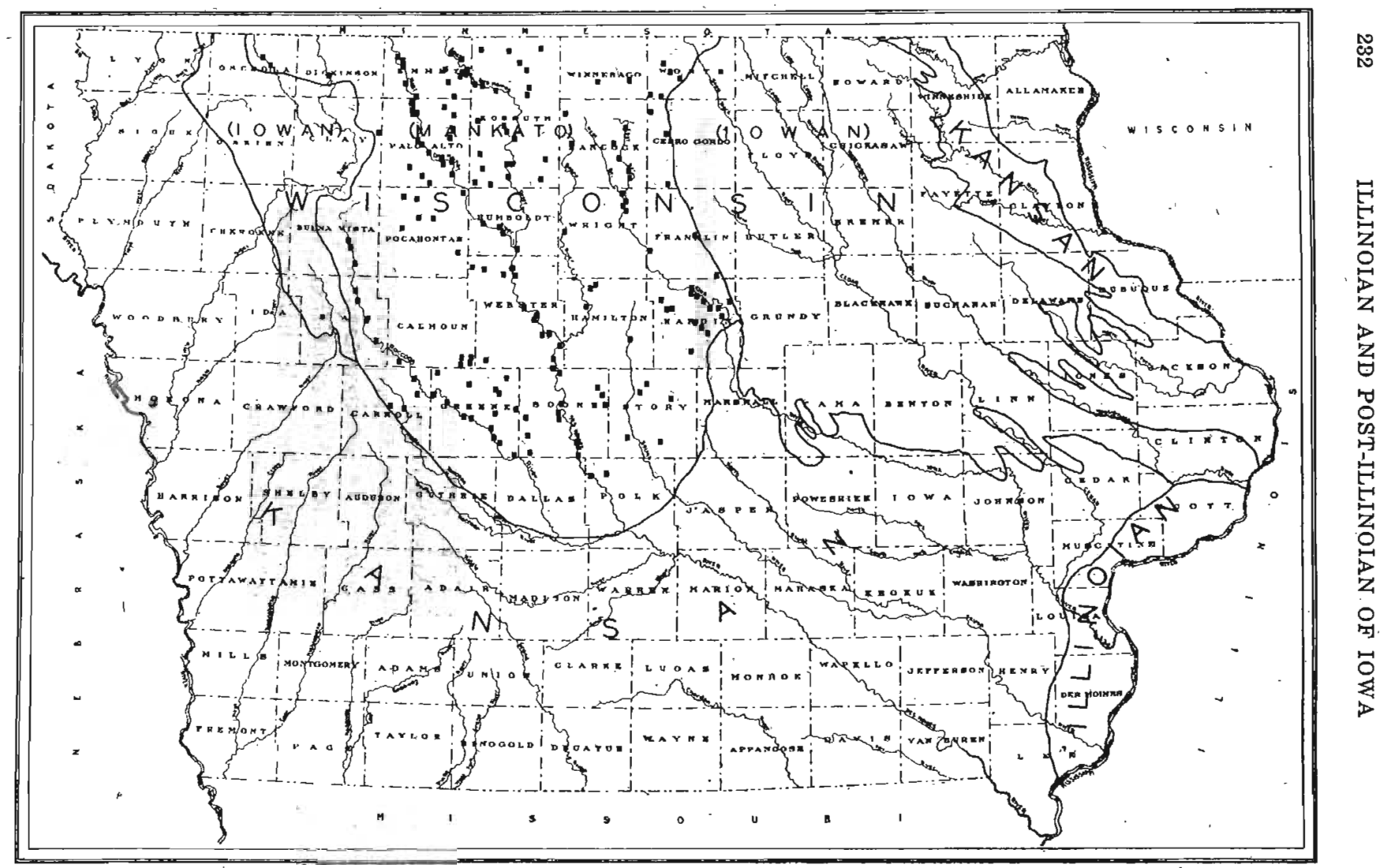

Figure 82. Map of Iowa showing locations of Mankato terrace gravel deposits. 
The gravel is very slightly oxidized and such buff color as is apparent is due to original color in the limestone and dolomite fragments. Leaching is normally found to a depth of about 30 inches, for the most part in the overburden; but where this is thin, it may extend into the underlying gravel. No disintegration of the igneous rock material is found. The limestone and dolomite content reaches as much as 60 per cent in one end of the pit, in which the platey fragments are imbedded in a matrix of much finer calcareous gravel. These plates lie characteristically with their long dimension parallel to the poor stratification of the finer gravel. For the most part the gravel in this exposure is well sorted, 85 percent of the average gravel is between the size grades of $1 / 2$ and 8 millimeters in diameter. The mechanical and lithological analyses of this gravel are shown as nos. 1 of figures 83 and 84 .

From a pit operated by the Chicago, Rock Island and Pacific Railway, Mankato terrace gravels have been reported to have been removed'to a depth of 45 feet. At present 20 feet of the gravel is exposed above the water in the pit.

The exposure occurs along the Des Moines River north of Graettinger, extending from the south central part of sec. 29 to the center of sec. 32, High Lake Township, (T. 98 N., R. 33 W.), Emmet County. The silty overburden is pebbly, especially at the base of the 4 -foot average thickness. The gradational zone between overburden and gravel is thin. Leaching has removed the carbonates to a depth of 2 feet. Limestone pebbles occur below this depth in the overburden, and the gravel is composed of about 50 percent of carbonates. Hence, the gravel is light colored, a light buff gray. A few lenses and thin beds are more deeply stained by iron oxide. Stratification is marked, the beds averaging about 2 feet thick and dipping slightly to the southwest. - Cross bedding and lens-andpocket structures occur within beds of finer material. In size, the gravel is mostly smaller than 3 centimeters in diameter. Boulders are rare. The size grade percentages and the pebble lithology are given as nos. 5 in figures 83 and 84, respectively.

An example of Mankato terrace gravel in the Raccoon River Valley is found near the center of sec. 13, Jackson Township, (T. 83 N., R. 31 W.), Greene County, about one-half mile from the southwest corner of Jefferson. Here 13 feet of gravel is exposed in a terrace 20 feet above the level of the river.

The irregular surface of the gravel is covered by 2 to 4 feet 

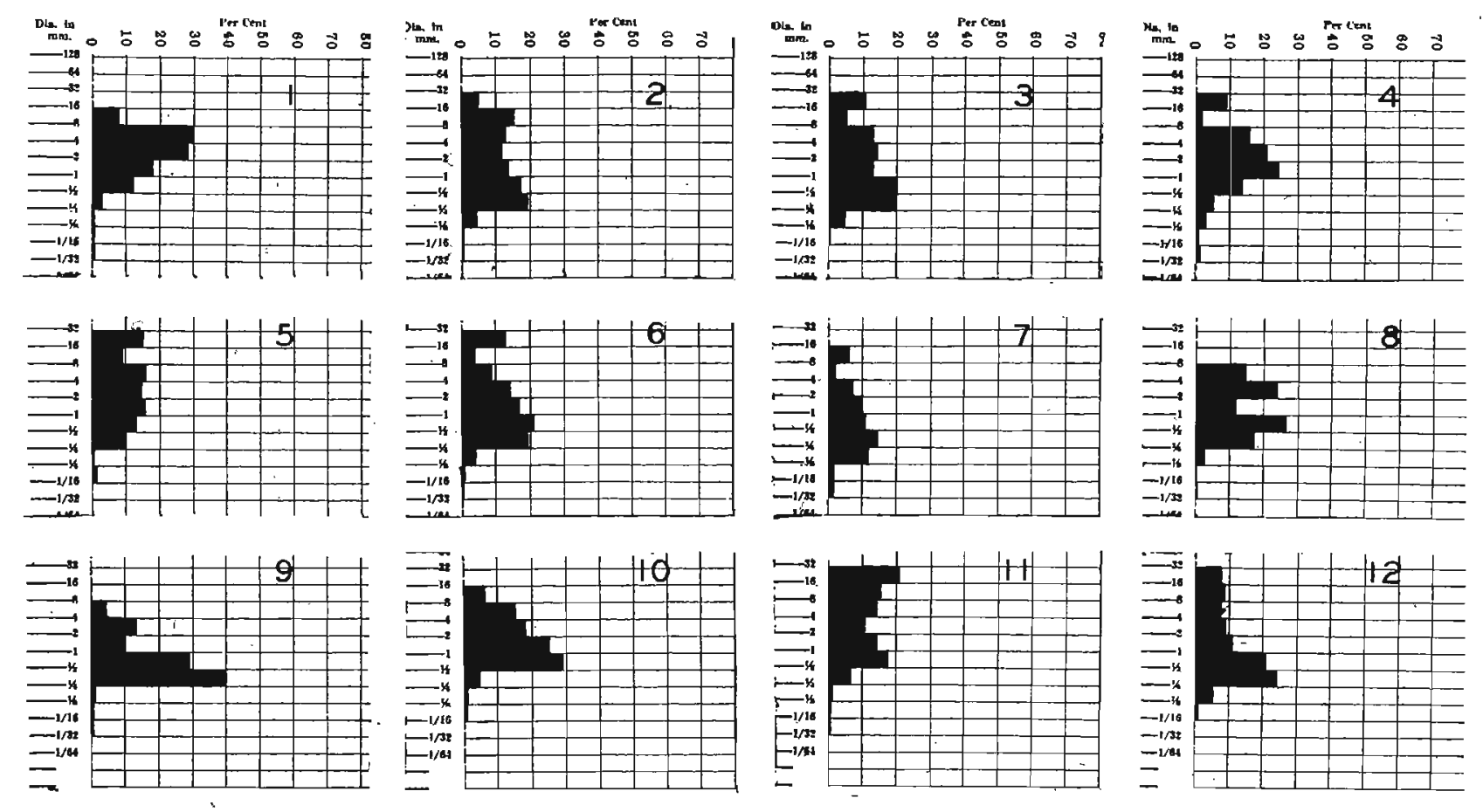

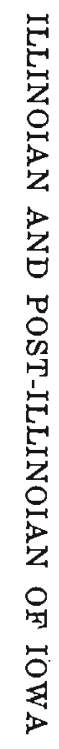

Figure 83. Graphs showing mechanical analyses of Mankato terrace gravels. 


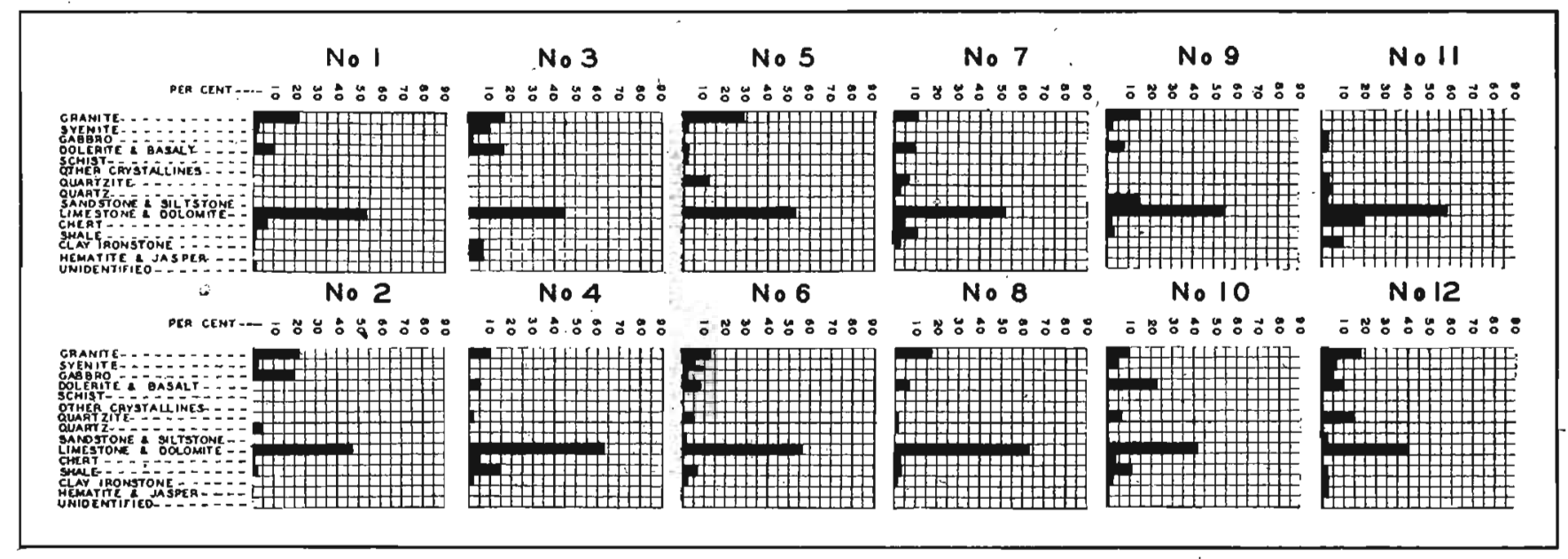

Figure 84. Graphs shuwing lithological analyses of Mankato terrace gravels within the size range 16 to 32 millimeters in diameter. 
of overburden. Leaching' in the thicker overburden has penetrated downward 40 inches. Where the gravel cover is about 2 feet, the upper few inches of the gravel is leached. The color of the deposit lightens downward. The leached overburden is chocolate brown from humus and oxidation. The unleached overburden is light brown and contains some limestone pebbles. A layer of 1 to 4 feet of coarse gravel just below the overburden is a light rusty brown below which the main body of gravel shows less oxidation and is a light grayish buff. The deposit is poorly stratified, with some beds about 30 inches thick which dip at a low angle to the north. Cross bedding is abundant in some of the horizons, the angle of dip being about 40 degrees in various directions. In size, most of the gravel is finer than 3 centimeters in diameter and nothing larger than 10 centimeters in diameter was observed. The diagrammatic representation of the size grades is shown as no. 6 in figure 83. The lithologic percentages are given in no. 6 of figure 84. Due to the quick disintegration of the shale content upon exposure to agencies of weathering, the shale does not appear in the above pebble analysis in its true proportions. Besides the shale, some of the granites and schists in the upper layer of coarse gravel are weathered.

Many other exposures of Mankato terrace gravel similar to those given above have been examined and studied. The valleys in which they occur may have been formed in the Buchanan interval and partially filled but not destroyed by Iowan and Mankato drift, leaving shallow linear sags which became the drainageways for the meltwater of the retreating Mankato glacier. Other terraces are found in valleys which do not indicate a history prior to Mankato glaciation and hence were developed by consequent streams uninfluenced by previous drainage lines. Within the Mankato drift, the identity of the gravel making up the terraces in the drift valleys is without question Mankato in age, but beyond the drift borders such gravel can be distinguished only by its relation to known till and loess deposits. Some exposures show the gravel in superposition with Peorian loess; and this can be determined as Mankato gravel with assurance. But in many cases, the relation of the gravel to underlying deposits is not visible, and while topographically it may be inferred that the terrace is an extension of levels existing on the Mankato drift, the gravels in themselves are not distinct from older terrace gravels and are thus classified as undifferentiated terrace gravels. 


\section{The Mankato Morainic Complex}

The surface of the Mankato drift is generally a flat or slightly undulating plain except for a more or less well-developed constructional morainic topography consisting of low-lying moundlike hills and depressions on the ground moraine surface, as shown in figure 85. As a whole, the knobby, kame and kettle topography characteristic of fresh terminal and recessional moraines is not pronounced in the Mankato area, and ridge-like morainal deposits existing as prominent features on an otherwise flat and low plain are not always apparent. Two main morainic systems, however, are fairly distinct and have long been recognized by geologists and soil men familiar with this region.

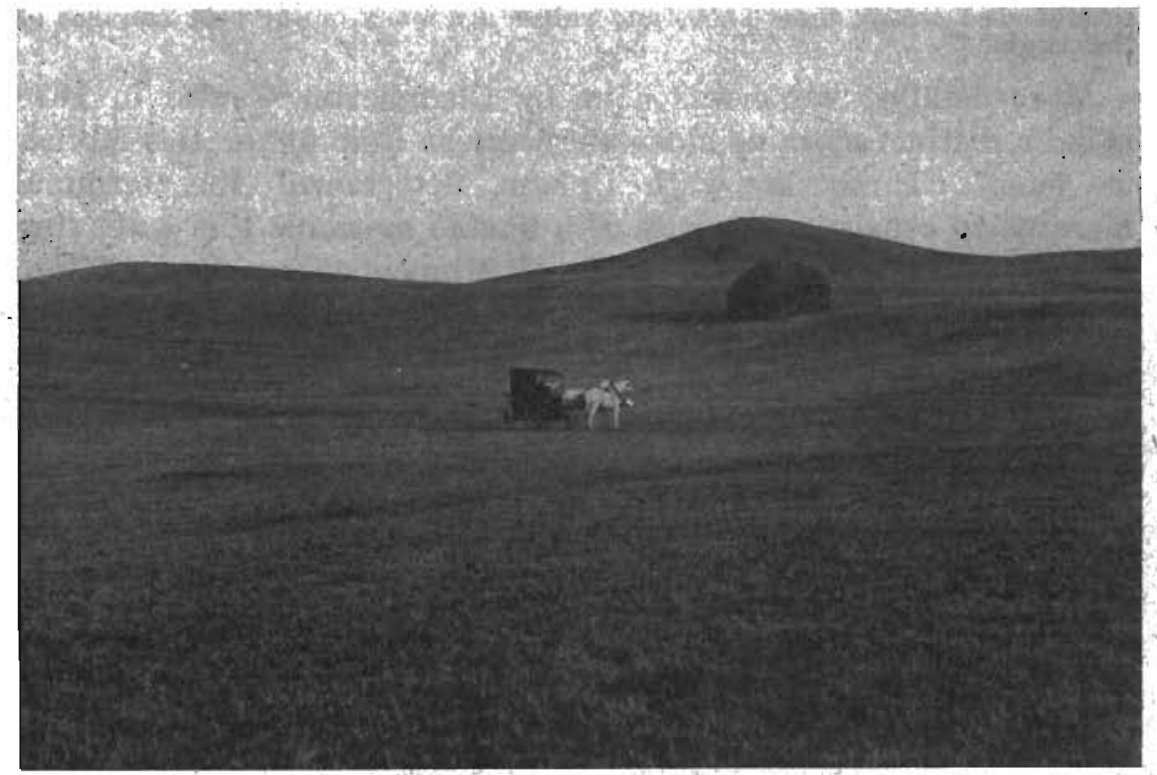

Figure 85. Mankato morainic topography; Wright County.

White, ${ }^{124}$ as-early as 1870 , correctly interpreted some of the more prominent morainic features of the area: He describes two of the most noticeable morainic features in the following manner:

"They (the moraines) seem at least to be accumulations of drift material which mark periodical arrests of the recedence by melting, of the glaciers to the northward as the Glacial epoch was drawing to a close, as a consequence of a gradual change of climate. They consist of two well-marked but

\footnotetext{
121White, C. A., The geology of Iowa, report on the geological survey of Iowa : val. 1, pp. 98-99,
} 
slight elevations in the general surface of the country. They both have an ensterly and westerly direction, and are gradually lost at either end in the general prairie surface. One of them extends through the northern part of Boone and Story counties, and is known to the inhabitants as 'Mineral Ridge.' It consists to a considerable extent of a collection of slightly raised ridges and knolls, sometimes interspersed with small, shallow ponds; the whole having an elevation probably nowhere exceeding fifty feet above the general surface, but being in an open prairie region it attracts attention at considerable distance. It is composed wholly of drift.

"The other ridge extends from the eastern part of Palo Alto county through Kossuth into Hancock. The greater part of this ridge has the general, but indistinct character of a terrace, facing the south, and elevated only from fifteen to twenty or thirty feet above the general level of the surface to the southward, while the general level to the northward stretches away from the top of it. It is nowhere very distinctly marked even in so flat a region as this, but yet it is sufficiently so to have caused its existence to become grenerally recognized by the inhabitants. Its eastward extension into Hancock county becomes broken up into a well-marked strip of 'knobby country.' Here it consists of elevated knobs and short ridges wholly composed of drift, and usually containing more than an average proportion of gravel and boulders. Interpressed among these knobs and ridges are many of the peat marshes of that region."

More detailed work was done by Chamberlin, ${ }^{125}$ who in 1878 noted a distinct moraine along the western limb of the Des Moines ice lobe. Chamberlin, with Upham, determined the terminal moraine to consist essentially of a double morainic line extending from a point a few miles south of Minneapolis southward into Iowa as far as Polk County, then doubling back to the north and west to the southern Minnesota line, from there following the northeastern slope of the Coteau des Prairies to its head in South Dakota to the west of Lake Traverse. In Iowa, the trend was described as extending diagonally across western Worth and southeastern Winnebago, western Cerro Gordo and eastern Hancock, Franklin, Hardin, Story and Polk Counties, crossing the Des Moines River a short distance below the capital city. From there it stretches northwesterly along the Middle Racoon River, diagonally through northeastern Guthrie and central Carroll into Sac County, then northerly in Buena Vista County, to the east through eastern Clay, and westward again through central Dickinson and northeastern Osceola Counties. This description is essentially that of the outermost moraine as mapped by Iowa geologists today. Upham and Chamberlin described the inner morainic line as running from Hancock County south through eastern Wright and Hamilton Counties where it curves to the west to include Mineral Ridge, which had been described earlier as a moraine by White. From Mineral Ridge the moraine continues across north-

120 Chamberlin, T. C., Preliminary paper on the terminal moraine of the second glacial epoch: U. S. Geol. Survey, 3d. Ann. Rept., pD. 388-893, 1881-1882. 


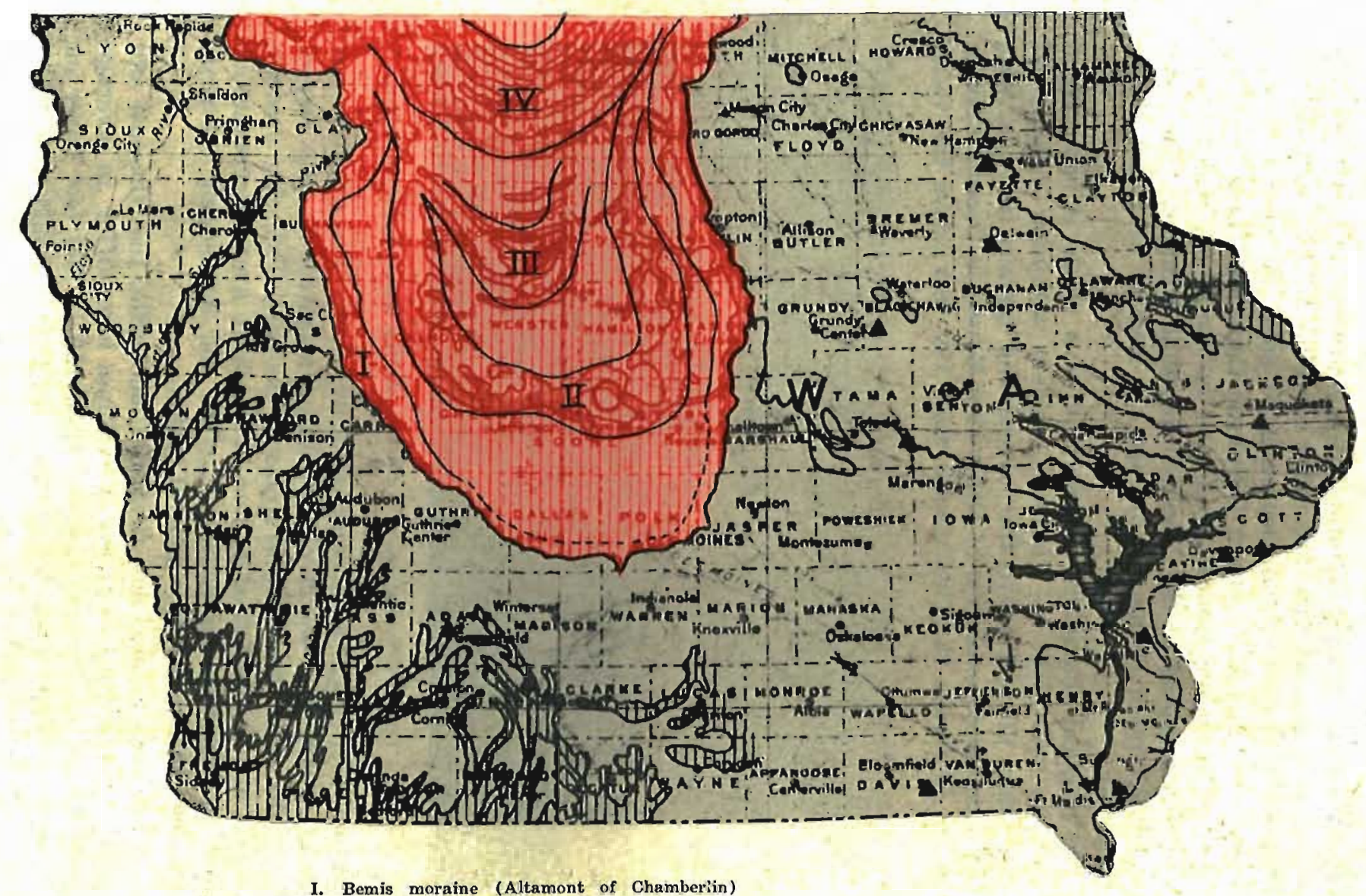

录

II. Bemis moraine (Altamont of Chamberiin

IV. Alimboldt moraine

Figure 86. Glacial map of Iowa with the major Mankato moraines indicated by number. 
ern Boone and Greene Counties, thence north to Palo Alto County where it coalesces with the outer moraine at the easterly reentrant of the latter, but separates to enter Minnesota through western Emmet and eastern Dickinson Counties. These two main terminal morainic trends are shown in figure 86, which shows a recent mapping of the Mankato morainic complex. The outer and inner main terminal moraines are marked às I and II, respectively.

In physical character, the moraine as a whole is less rugged than its equivalent in Wisconsin, seldom attaining heights of more than 50 feet above the surrounding terrain in Iowa, with the pronounced exception of Ocheyedan Mound in Osceola County, shown in figure 87. This mound rises 150 feet above the valley

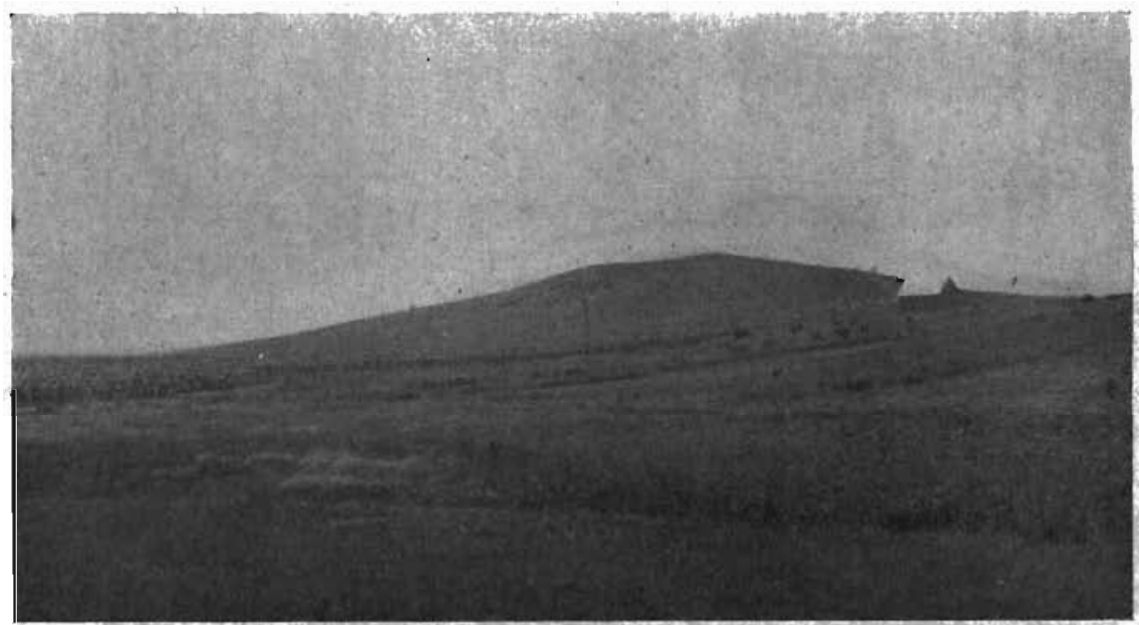

Figure 87. View of Ocheyedan Mound, a Mankato morainic feature in Osceola County.

bottoms and covers an area of about 40 aeres. The morainic material is largely a clayey till, differing markedly in this respeet from the rocky moraines of areas to the east. This clay predominance may be explained as due to the large areas of Cretaceous shale constituting the bedrock surface and influencing the drift lithology throughout this general region.

It has been pointed out, first by Chamberlin, that the east and west morainal borders of the Des Moines lobe differ in average elevation by an amount ranging from 150 to 200 feet lower on the east than the west. Whether the ice tongue would have taken 
its observed direction rather than following the dip of the surface to the east, had this entire elevational difference existed in Mankato time, is not known, but it is considered unlikely. However, there is little topographic evidence either in western or eastern Iowa which can be presented to substantiate a relative shift in elevation of as much as 150 feet, though western Iowa is thought to have received a relative elevation over eastern Iowa of unknown proportions in the post-Kansan pre-Iowan interval.

In the report by Chamberlin ${ }^{126}$ cited above, the name Altamont moraine was given to the moraine which to that author seemed to be the outer terminal moraine of the lobe in its continuation in the Iowa part of the drift. The name was taken from the town of the same name situated on a prominent morainal elevation in the eastern part of South Dakota. An inner moraine not far to the east of Altamont, South Dakota, passes through Gary and vicinity, a town situated on the South Dakota-Minnesota state line, and from this locality the name Gary has been taken for the moraine which parallels the Altamont moraine on the east, and which was thought to be manifest in Iowa as the inner moraine including Mineral Ridge. These two morainic belts are separated in the region of the type localities by a distance of 5 to 6 miles of gently undulating drift plain. There is little difference in the massiveness, breadth, height, complexity or constitution of the Altamont and Gary moraines, as identified by Chamberlin. Still to the east of the two prominent ridges, a third and more feeble morainic trend, locally known as Antelope Hills, lies at a distance of 12 to 15 miles east of the Gary moraine and roughly parallel to the outer two.

This terminology for the Des Moines lobe terminal moraines was used as originally described until Leverett ${ }^{127}$ in 1922 published the results of field investigations by Lees and himself in which the use of the name Altamont for the outer moraine of the lobe is questioned. According to Leverett, there exists a moraine a short distance to the west of the type locality of the Altamont moraine, passing through the town of Bemis, South Dakota. This moraine parallels but is distinct from the Altamont moraine and is traceable southward as the true outer moraine, the Altamont moraine in actuality being the inner moraine in "Iowa. Leverett

\footnotetext{
${ }^{128}$ Chamberlin, T. C., op. cit., p. 398, map, pp. 882-383.

wheveret, Frank. What constitutes the Altamont moraine: (Abstract) Geol. Soc. America Bull., vol. 88, pp. 102-108, 1922.
} 
gave the name Bemis to the outer moraine and suggested the continued use of the name Altamont for the moraine passing through the town of that name but now considered to be the inner rather than the outer terminal moraine in Iowa. This usage is adopted in the present report and has been applied to the map shown in figure 86.

In a report on fertilizer materials of fowa, published by J. E. $\mathrm{Smith}^{128}$ in the reports of the Geological Survey of Iowa, a map of the Des Moines lobe morainic system is given in which Chamberlin's original application of the name Gary for the inner moraine is used, and two prominent recessional stages of the melting glacier are mapped, termed the Humboldt and Algona stages in respective order inward. These are shown as moraines III and IV in figure.86.

The question as to the approximate contemporaneity of these various moraines of the Des Moines lobe has never become an issue due to the obvious array of evidence pointing to normal stages in the advance and recession of a single glacial mass. In morainal characters as to material, topography, position, and reduction by erosion; in appearance, and relation of outwash materials to drainage features; in degree of surface till modification by weathering of the various areas of the lobe; and in physiographic age of the various areas of the lobe, the similarities are so striking and the unity of the effects of glaciation so apparent, that glacial geologists have in general accepted the single glacier view of the Mankato drift in Iowa and its morainic complex.

\section{Thickness of the Mankato Drift}

Reference has already been made to the fact that few highway or railroad cuts of any great depth are to be found within the strikingly level area of the Mankato drift. Consequently, with the exception of a few exposures near the drift borders, good sections of the till showing the entire depth are rare. Yet a study of such sections as are available, aided somewhat by well logs, indicates an average depth of about 30 to 35 feet for the Mankato till, though considerable variation in thickness is found. Thus, in Greene County, a fine section in the $N_{1} 1 / 2$ sec. 27, Grant Township, (T. 83 N., R. 30 W.), shows a thickness of 44 feet of Mankato till overlying from 6 to 20 feet of Peorian loess. In contrast, many sec-

1285mith, J. E., The fertilizer materials of Iowa: Iowa Geol. Survey, vol. 31, opp. p. 102 1923-1924. 
tions show a depth of but 5 to 10 feet of Mankato till, a thickness which is more characteristic of the veneer-like Iowan than the generally constructional Mankato.

But the Mankato, as the Iowan drift, is not of sufficient thickness to have become completely distinct in its topography. Some of the drainage lines on the Mankato surface were inherited, not only from the Iowan surface, but through it from the eroded topography of the Kansan plain. Yet the general features of the hummocky plains of north-central Iowa have been thought to be entirely Mankato in origin and the region as a whole displays a drift depositional topography.

A somewhat different view of the morainal features of the Mankato drift-a view which implies a relatively thin drift sheet-has been presented by C. S. Gwynne, ${ }^{129}$ who suggests that the mappable morainic features in the Mankato area are Iowan moraines which find surface expression through a thin and essentially moraine-less Mankato drift. This argument is based upon a study of aerial photographs which seem to indicate trends of the Mankato ice margins with no apparent relation to the much larger morainic features which have been mapped by field surveys.

\footnotetext{
${ }^{129} \mathrm{Gwynne}$ C. S., Swell and swale pattern of the Mankato lobe of the Wisconsin drift plain
in Iowa: Jour. Geology, vol. $50, \mathrm{pp} .200-209,1942$.
} 


\section{GHAPTER IV. \\ THE ELDORAN EPOCH (SERIES) \\ THE RECENT INTERGLACIAL AGE (STAGE)}

The record of the Recent

Descriptions of Recent features

Leached Mankato drift

Peat on the Mankato drift

Duration of the Recent

The term Recent was used first by Charles Lyell ${ }^{130}$ for the period during which the earth has been inhabited by man. This original use would include the Recent and Pleistocene of the present classification. Following Forbes' re-definition of the term Pleistocene in 1846, the term Recent came to mean "post-glacial," and has carried that meaning down to the present time.

The Recent, by most geologists, has not long been considered a part of the Pleistocene, or Glacial period. Rather, it has been largely left as the domain of other fields of science, and until recently, much of what was known about geological conditions since the retreat of the last continental glaciers from North America came through interest in anthropological, archeological, and biological problems. Within the past few years, however, geologists have turned to sedimentational studies of existing late Glacial lakes, to tree rings, to cores taken from ocean bottoms, to cave deposits, and to soil zones in Wisconsin and Recent loesses, and progress is slowly but surely being made in exposing the conditions of the recovery, or partial recovery of North America from Wisconsin glaciation.

The place of the Present in relation to glacial and interglacial conditions can never be completely known by contemporary science for such obviously presumes knowledge of the future. However, most glacial geologists are of the opinion that the Present is not dissimilar from conditions which probably prevailed in the recovery phases of earlier interglacial ages. That the Present is not far advanced in point of time from glacial conditions, is evident from studies of existing but waning continental ice sheets in Greenland and Antarctica. It may be properly said that in those regions the Recent interglacial age is yet to come.

1s0Lyell, Charles, Principles of Geology, vol. 3, pp. 52-53, 1833. 
Kay and Leighton, ${ }^{131}$ in proposing to include the Recent in the Pleistocene, state:

"During the Recent age the Mankato (Late Wisconsin) drift on uneroded uplands has been leached of calcium carbonate to a depth of about 30 inches. The time involved is considered to have been approximately 25,000 years. Since there is no evidence that the Recent may not be the beginning of another interglacial age, it would seem to be logical to regard the Recent as a part of the Pleistocene, or Glacial; period."

\section{THE RECORD OF THE RECENT}

The Recent, as interpreted in Iowa, includes that interval of time beginning with the disappearance of the late Wisconsin, or Mankato, ice sheet, and extending to the present. It is perhaps needless to add that this concept of the Recent in relation to the Pleistocene of Iowa will not be the exact time equivalent of the Recent in other regions.

All materials which have been deposited subsequent to the deposition of the Mankato drift in Iowa are Recent deposits, and also, all changes which have affected the Mankato drift or materials of later deposition, are changes which occurred in the Recent age. It follows, therefore, that deposits and changes in Iowa bellonging to the Recent must be related to the Mankato drift to carry proof of belonging to the Recent. An exception-which is used by students of human pre-history - would be deposits anywhere which can be shown to contain Recent life forms, such as Indian remains.

Within Iowa, the most important factors in the study of the Recent record are the changes to be seen in Mankato deposits. Oxidation and leaching of the calcium carbonate have occurred and these changes serve as the best approach to the relative duration of the Recent. The stage of erosion serves as a useful tool of comparison. Recent deposits are relatively unimportant, for the reasont that with the exception of peat, no past-Mankato materials have been recognized on the Des Moines lobe, and because few deposits beyond the Mankato borders can be delimited as post-Wisconsin.

Elsewhere, good use has been made of human cultural levels, Recent soil zones, lake bottom accjumulations, etc., but these criteria have not been applicable. in Iowa because of the scareity of such deposits.

\footnotetext{
191Kay, G. F., and Leighton, M. M., The Eldoran epoch of the Pleistocene period: Geol. Soc.
} America Bull., vol. 44, D. 673, 1933. 


\section{DESCRIPTIONS OF RECENT FEATURES}

\section{Leached Mankato Drift}

The three oldest drifts in Iowa, namely the Nebraskan, Kansan and Illinoian, were in each case exposed to weathering agencies for a sufficient length of time to allow a widespread development of gumbotil, mesotil or silttil wherever the drift plain was not being reduced by erosion. The lowan substage of the Wisconsin stage does not have a gumbotil development but is leached of its calcium carbonate to an average depth of $51 / 2$ feet. The Mankato substage exhibits the least change of all. There is no gumbotil development, and the depth of leaching is but $2 \frac{1}{2}$ feet on the average-less than one-half that of the Iowan. Figure 28, page 108, illustrates the depth of leaching at numerous sections in both the Iowan and Mankato drift areas.

There can be little doubt that there is a close relationship between the time during which weathering agencies of interglacial ages acted on glacial materials and the depth of the resulting chemical changes. In the case of the Mankato drift the only determinable results have been the slight leaching of about 30 inches, and a variable amount of oxidation which in most places. extends to a depth of less than 10 feet.

This lack of any pronouneed change in the original drift material is an indication of extreme youth, and is in complete accord with other criteria of age. The stage of exosion, the poorly developed drainage pattern, the lack of mappable loess on the till, and the unreduced forms of the various constructional drift features all substantiate the interpretation put on the amount of leachingthat in a geological sense, the Recent has been extremely short.

\section{Peat on the Mankato Drift}

Immediately upon the withdrawal of the Mankato ice from north-central Iowa, such plant life as was suited to the cool and wet conditions of the barren expanse of fresh till began to spread over the drift surface. Mosses, sedges and grasses, and more infrequently shrubs and trees soon brought verdure back to the region. Marsh and swamp plants became established around the pond and lake borders and aquatic plants grew outward into the open water in matted masses. The poor development of drainage systems, the probable abundance of water and the climatic fac- 
tors suitable for rapid and abundant growth of many types of land and fresh water plant life all indicate that conditions necessary for the widespread formation of peat were present.

Peat may be defined in a.non-technical sense as partially decayed plant debris, the normal process of complete oxidation being arrested by a covering of water: Peat is ordinarily found as a fibrous, matted mass of brown to black plant material, but may in places be a non-fibrous, structureless muck or mud in which the plant debris has been changed almost beyond recognition as organic structures. It normally is very high in water content, ranging from 75 to 90 percent when first cut, and when air-dried may retain from 10 to 25 percent of water. Fibrous peats have a higher water content than that which is less fibrous. Fresh water shells are frequently found in the peat.

Peat may form in bogs, swamps or marshes, generally in depressions but in places on gentle hillsides at the site of seeps and springs. It may develop from almost a single type, or more often from a heterogenous group of plant forms including shrubs and trees, but Iowa Recent peats in the Mankato drift region have been found to consist primarily of grasses and sedges with mosses of secondary importance. Shrubs and trees are rare.

Most of the peat bogs of importance in the state are found within the borders of the Mankato drift, although small bogs are known to exist among the sand dunes formed in Wisconsin time and in Recent time along, some of the main drainage systems of the state. The peat deposits of the Mankato drift are concentrated along the principal morainal belt on the east side of the lobe. They vary greatly in area and depth. They range in areal extent up to 1,500 acres and in depth to more than 35 feet. The deepest bogs are found in the rough knob and kettle topography of morainal areas, while the shallow peat deposits, which usually contain a poorer quality of peat than the deeper ones, occur in the more gentle depressions on the open drift plain.

A thorough study of the peat deposits of the Des Moines lobe was made by the Iowa Geological Survey, and a complete report of locations, thickness, and laboratory analyses of many samples was prepared by S. W. Beyer. ${ }^{132}$ Figure 88 shows the location of the peat deposits in the Mankato drift area which were considered by Beyer to be large enough to present commercial possibilities.

\footnotetext{
132Beyer, S. W., Peat and peat deposits in Iowa : Iowa Geol. Survey, vol. 19, pp. 693-730, 1909.
} 
Many of the locations on the map represent several deposits in conjunction.

Pollen profiles in buried peats in Iowa have been discussed earlier in the report. Application in America of pollen profiles in post-glacial peats has been gaining prominence following a much greater use of this method in Europe. Investigation of Recent peats has demonstrated the use of pollen profiles in archeological correlation; in climatic interpretations; and to some extent in estimates of Recent time. ${ }^{133}$

\section{DURATION OF THE RECENT}

Of even greater general interest than the span of time covered by the ice age as a whole is the length of time since Iowa was last buried under hundreds of feet of ice. This interest is strengthened by the fact that the human species probably inhabited North America during or just after the existence of the last continental ice sheet, and by the proved co-existence with man of several types of animal life of enormous size, now extinct.

Two lines of argument may be followed: (1) that man in North America is much older than formerly believed and has had considerable history on this continent, or (2) the time since glacial conditions prevailed in northern areas of the continent has been relatively short, and the presence of man in association with now extinct animals, and perhaps associated with deposits of glacial age, merely indicates the shortness of time since glacial conditions existed. The answer to this problem, and to the problem of yet more definite figures for the duration of the Pleistocene period as a whole, will be answered ás the geological events of the Recent are gradually solved.

The effects of chemical and physical processes working on surficial Mankato materials have been discussed already in detail. Calcium carbonate has been leached from the upper 30 inches of till, on the average. Oxidation has proceeded to greater depths. The most constant process, that of leaching, affords a means of comparing post-Mankato time with time intervals during which older drifts were exposed to atmospheric agencies. This method of comparing the duration of the various drifts to weathering by the use of depths of leaching in their exposed gravels is explained

\footnotetext{
${ }^{238}$ Sears, $P$. B., Pollen analysis as an aid in dating cultural deposits in the United States: Early man, J. B. Lippincott Co., London, pp. 61-66, 1937.
} 


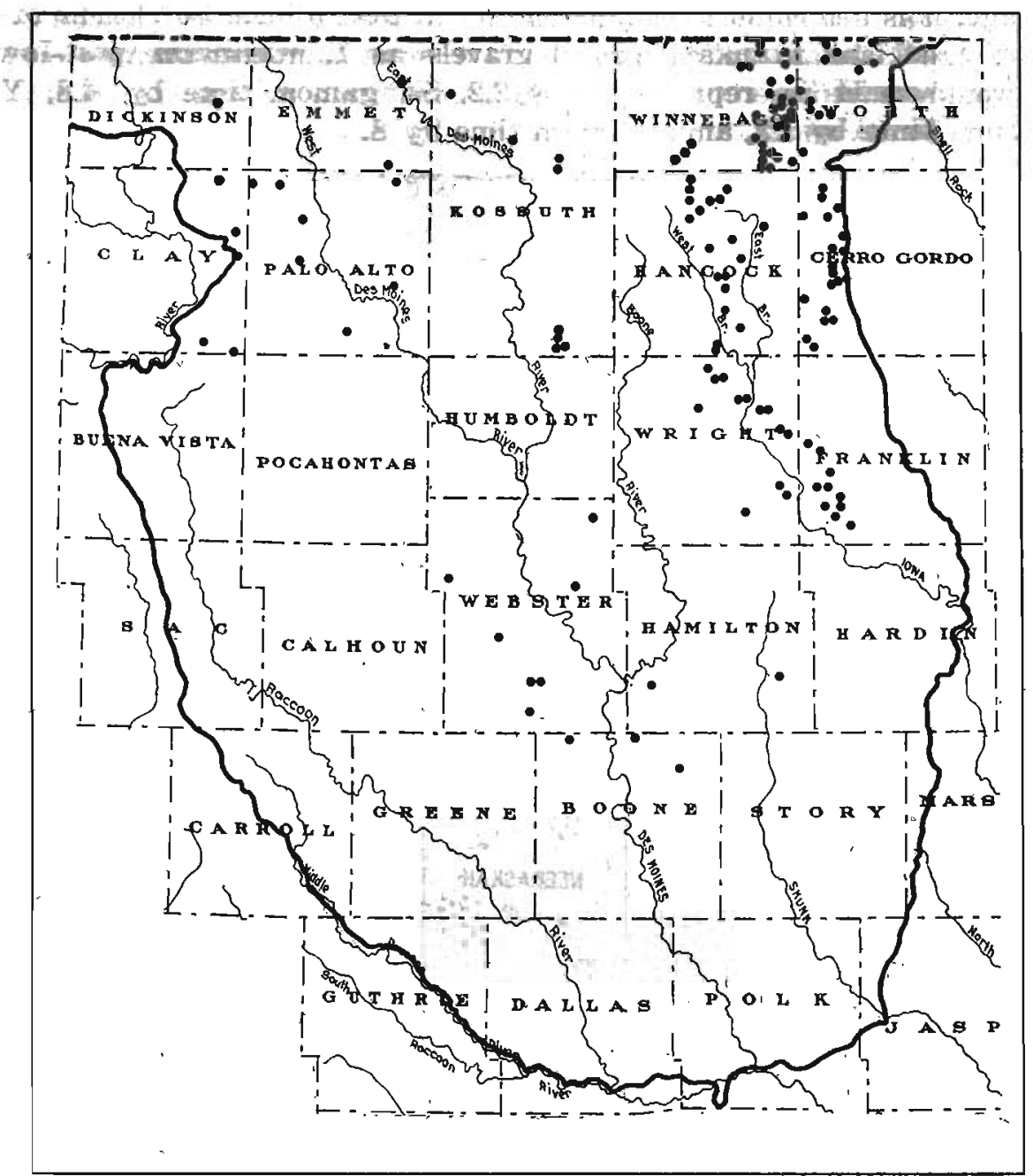

Fisure 88. Map of the Mankato drift area in Iowa showing locations of peat deposits.

in detail by Kay. ${ }^{134}$ Figure 89 indicates the depth of leaching of upland gravels in the various drift sheets. It may be seen from this comparison that by giving the depth of leaching on the Mankato drift a value of unity, a useful and simple set of ratios may be set up for the relative minimum duration of the weathering of other drift sheets in Iowa. Assuming that the leaching of each fresh drift sheet progressed at a constant rate in each interglacial

196.Kay, G. F., Classification and duration of the Pleistocene period: Soc. America Bull, vol. $42, \mathrm{pp}, 452-466,1931$. 
age, it is determined that in relation to the 30 inches of leaching of the Mankato upland gravels as 1, minimum post-Iowan time would be represented by 2.2 , Sangamon time by 4.8 , Yarmouth time by 12, and Aftonian time by 8.

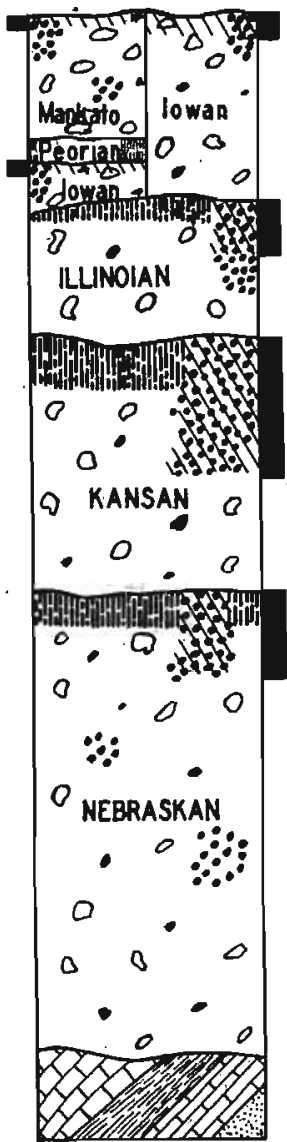

Figure 89. Diagrammatic representation of the depth of leaching of upland gravels in the various drift sheets of Iowa.

The determination of the duration of post-Mankato time in number of years has been attempted along several lines. ${ }^{135}$ Among the methods which have received the most study are: the rate of recession of certain waterfalls which began their retreat since the last ice sheet disappeared; the amount of post-glacial erosion where the annual rate can be approximated; the recession of wave-cut cliffs; the counting of overlapping series of varved

106lint, R. F., Glacial geology: Geol. Soc. America, 50th Anniv. Vol., pp. 31-38, 1941. 
clays; and the rate of crustal upwarping following ice disappearance. New methods which offer some promise of solution include the study. of the rate of radioactive disintegration of hot-spring deposits, the difference between the present magnetic declination and the alignment of magnetic particles in drift sheets, allowing use of the rate of change in magnetic declination, and the rate of recession of the ice front as indicated by a swell and swale pattern produced by seasonal influences. ${ }^{136}$

At the present time, varves have yielded the best results in establishing the chronology of the Recent age, but the method is limited due to the restricted conditions for the formation of varved clays. De Geer in Sweden, and Antevs in America, have had considerable success in this type of investigation. However, the probability of finding as complete a varve series in North America as De Geer has found in Sweden is slight.

All figures of the number of years which have elapsed since Mankato ice receded from northern United States are as yet estimates with broad limits of error. However, an average of estimates based on the several methods of computation indicates that a figure of from 20,000 to 25,000 years for post-Mankato time in the Iowa region is the best figure warranted by our present geological information. This figure has been generully used by geologists, and by anthropologists dealing with early Man.

The need for a dependable figure in years for post-Mankato time is readily apparent. Upon it hinges to a large extent the best determination of the duration of the entire Pleistocene and its constituent epochs.

isoGwynne, C. S., Swell and swale pattern of the Mankato lobe of the Wisconsin drift plain in Iowa: Jour. Geology, vol. 60, pp. 200-209, 1942. 
Appendix-Chart I

TABULATION OF PUBLISHED ANALYSES OF LOESS AND LOESS-LIKE MATERIAL 19

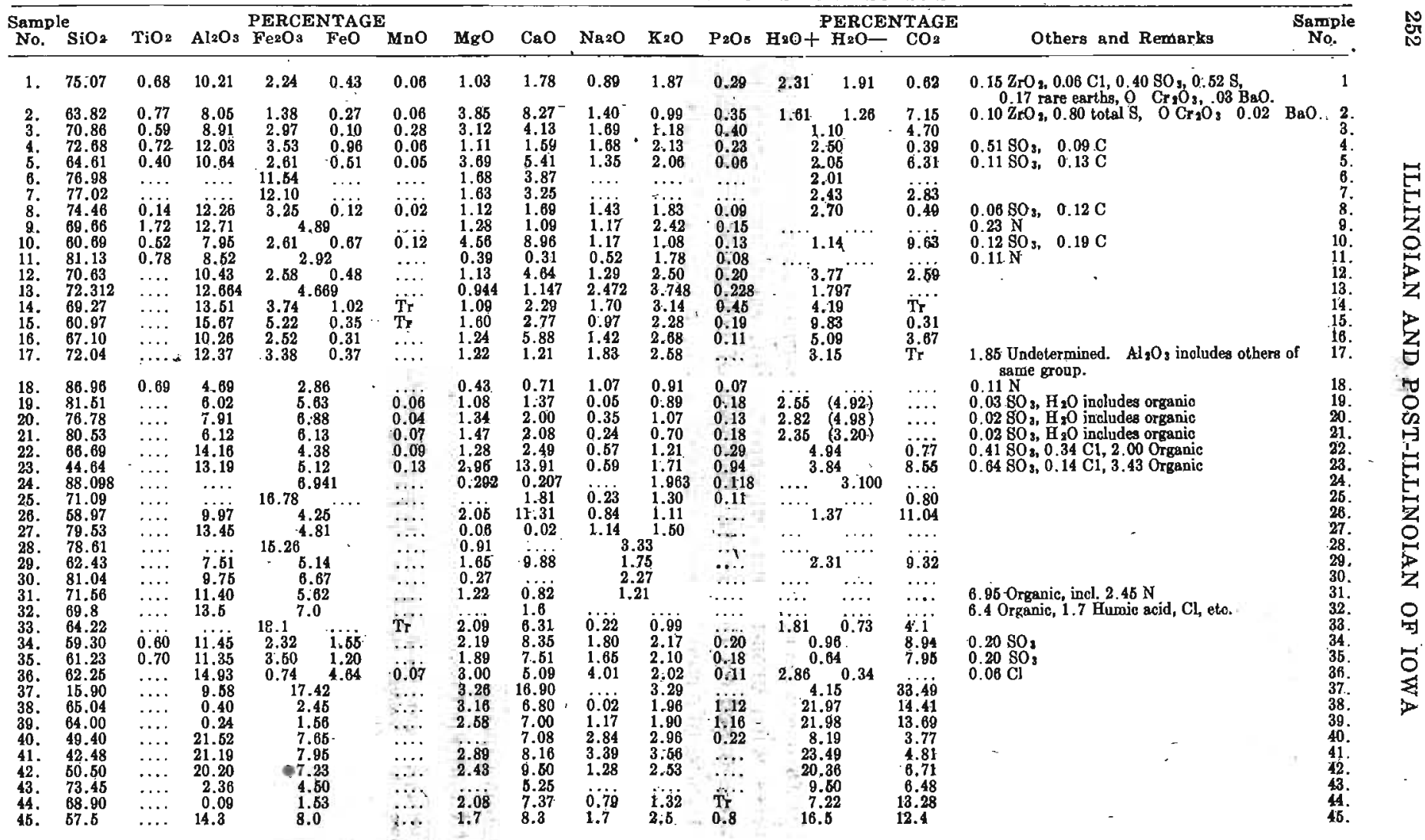
me key to the foregoing tabolation of loess analyses appesrs on the succeeding pages. The key includes the sample number and where poseible
the locality, literature reference and analyat. 


\section{KEY TO TABULATION OF LOESS ANALYSES}

Sample No.

Analyst

1. No. 5M, Peorian loess, Johnson County, etc. No reference.

L. C. Thomas

2. No. 77M, Peorian loess, Fayette County, etc. No reference.

3. Mt. Vernon loess from Cornell campus. Knight, N., Analysis of Mount Vernon loess: Am. Jour. Sci., 4th ser., vol. 13, p. 325, 1902 .

L. C. Thomas

4. Loess from summit of ridge, Dubuque Iowa Chamberlin, T. C. and Salisbury, R. D., Preliminary paper on the Driftless Area of the upper Mississippi Valley: U. S. Geol. Survey 6th Ann.

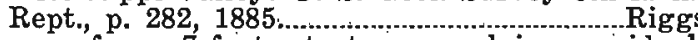

5. Loess from 7-foot stratum overlying residual clay, Galena, Illinois. Chamberlin, T. C. and Salisbury, R. D., idem., p. 282 ............................ U. S. Seol. Survey

6. Loess from Hannibal, Missouri. Hayden, F. V., Final Rept. of the U. S. Geol. Survey of Nebras$\mathrm{ka}$ and portions of the adjacent territories: U. S. 42nd Cong. 1st sess., House Exec. Doc. 19, p. 12, 1872; Aughey, S., Sketches of the geography. and geology of Nebraska, p. 267, Omaha, 1880

7. Loess from Hannibil, Missouri. Hayden, F. V., idem., p. 12; Aughey, S., idem., p. 267.

8. Loess from Kansas Oity, Missouri. Chamberlin, T. C. and Salisbury, R. D., op. cit., p. $282 \ldots$....Riggs, U. S. Geol. Survey

9. Loess soil, Cherokee, Kansas. Bennett, H. H., The soils and agriculture of the southern states, New York, Macmillan Co., 1921.

10. Loess from Center Vicksburg, Mississippi. Chamberlin, T. C. and Salisbury, R. D. op. cit., p. 282

11. Memphis silt loam, 5 miles southwest of Granada Mississippi. Robinson, W. O., Steinkoenig, L. A., and Fry, W. H., Variation in the chemical composition of soils: U. S. Dept. Agr., Bur. Soils;

12. Typical eastern Colorado loess from near. Wray Robinson and Steinkoenig Colorado: Emmons, S. F., Cross; W., and Eldridge, G. H., Geology of the Denver Basin in Colorado: U. S. Geol. Survey Mon. 27, p.'263, 1896. …............................

13. Loess from the surface near the foothills at Gol-

U. S. Geol. Survey den, Colorado, Emmons, S. F., Cross, W., and Eldridge, G. H., idem., p. 263.................................... Georand, U. S.

14. Denver loess, 8 feet below surface on boulevard Survey near Ashland Ave., Denver, Colorado. Clarke, F. W., The data of geochemistry: U. S. Geol. Survey Bull. 770 , p. 514, 1924.

15. Early loess, 20 feet below surface near St. Luke's Hospital, North Denver, Colorado. Clarke, F. W., idem., p. 514 Eakins,

16. Loess from surface round near State House, Cheyenne, Wyoming. Clarke, F. W., idem., p. 514..........Eakins, U: S.

17. Loess, one mile east of Alta, Wyoming. BlackGeol. Survey welder, E., Post-Cretaceous history of western Wyoming: Jour. Geology, vol. 23, p. 338, 1915. W. C. Wheeler, U. S. Geol. Survey 
18. Silt loam, Weeping Water. Lyon, T. L. and Buckman, H. O., The nature and properties of soils; a college text of edaphology, New York, Macmillan Co., 1922; Barbour, G. B., Loess of China (with bibliography): Smithsonian Inst. Ann. Rept. for 1926, 1927.

19. "Dust soil" from plateau on Willow Creek, Morrow County, Oregon. Hilgard, E. W., A report on the relations of soil to climate: U. S. Dept. Agr., Weather Bureau, Bull. 3, 1892; Merrill, G. P., , A treatise on rocks, rock-weathering and soils, p. 345, New York, Macmillan Co., 1897.

20. "Dust soil" from Atathnam prairie, Yakima County, Washington. Hilgard, E. W., idem.; Merrill, G. P., idem., p. 345 .

21. "Dust soil" from Rattlesnake Creek, Kittitas County, Washington. Hilgard, E. W., idem.; Merrill, G. P., idem., p. 345 .

22. Adobe from Santa Fe, New Mexico. Merrill, G. P., idem., p. 334 .

23. Adobe from Fort Wingate, New Mexico. Merrill, G. P., idem., p. 334 .

24. Average compositions of 21 Quaternary (loess) soils of Kertucky. Chemical-Analyses, pt. A.: Geol. Survey of Kentucky, vol. 2, pt. 2, p. 113, 1885; Merrill, idem., p. 363.

25. Loess from Neubad, Switzerland. Merrill, G. 'P., idem., p. 330; Barbour, G. B., op. cit

26. Loess from roạd between oberdollendorf and Heisterbach. Bischof, C. G. C.: Chem. Geol., p. 127,1854 .

27. Loess from road between Oberdollendorf and Heisterbach, deducting carbonates and loss on ignition. Bischof, C. G. C., idem., p. 127.

28. Loess lying under above, destitute of carbonates. Bischof, C. G. C., idem., p. 127.

29. Loess from road between Bonn and Ippendorf. Bischof, C. G. C., idem., p. 127.

30. Sample as above after deducting carbonates and loss on ignition. Bischof, C. G. C., idem., p. 127.

31. Tchornozem or "black earth" of Russia: Murchison, R. I., Verneuil, E., and von Keyserling, A., The geology of Russia in Europe and the Ural Mountains, vol. 1, p. 560, London, John Murray, 1845.

32. Tchornozem or "black earth" of Russia from a depth of 10-12 feet. Murchison, R. I., and others; idem, p. 559 .

33. Loess from Honan, China. Barbour, G. B., op. cit., pp. 279-296.

34. Loess of Wei-ning Kausu, China. Barbour, G. B., op. cit., pp. 279-296. ...... China. Barbour, G. B. op. cit., pp. 279-296.

36. Dust from ice of Greentand. Free, E. E., Movement of soil material by wind; with bibliography of eolian geology, by S. C. Stuntz and Free: U. S. Dept. Agr., Bur. Soils, Bull. 68, p. 103, 1911 Bischof irocco dust fell at Tyrol, March 31,1847 . Ehrenberg, $C_{m}$ G., Passatstaub und Blutregen, ein grosses organisches, unsichtbares Leben in der Atmosphare: Abh. preuss, Akad. Wiss., Berlin, 1847; Free, E. E., idem., p. 93. 
38. Siroce dust fell at Palermo, April 14, 1847. Free, E. E., idem., p. 93.

39. Sirocco dust fell at Palermo, May 14, 1879. Free, E. E., idem., p. 93.

40. Sirocco dust fell at Naples, March 10, 1901. Free, E. E., idem., p. 93.

41. Sirocco dust fell at Taormina, Sicily, March 19 , 1901. Thorpe, T. E., "Red rain" and the dust storm of February 22: Nature, vol. 68, p. 222, 1903; Free, E. E., idem., p. 93

42. Sirocco dust fell at Lamberhurst, England, February 22, 1903. Thorpe, T. E., idem., p. 54; Free, E. E., idem., p. 93.

43. Siroceo dust fell at Tunis, Africa, March 10, 1901. Bertainchand, E., Sur les poussieres atmospheriques observees a Tunis le 10 Mars 1901: C. R. Acad. Sci. Paris, vol. 132, p. 1153, 1901.

44. Desert dust from Biskra. Tacchini, P., Sulle polveri meteoriche e l'analisi chimica della sabbia del Sahara: Roma, R. Accad. Lincei Trans., vol. 7, p. 135, 1883; Free, E. E. op. cit., p. 93.

45. Average chemical composition of Sirocco dust. Ehrenberg, C. G., op. cit., p. 30; Free, E. E., op. cit., p. 95 . 


\section{INDEX}

$\mathbf{A}$

Aftonian glacial age (stage), classification, 13

Aftonian loess (?), lithological analysis, 182

Alden, W. C. and Leighton, M. M., cited 159, 212; Iowan, 94, 125; pebble band, 134

Algona stage, 242

Altamont moraine, 239, 241

Antelope hills, 241

Antevs, Ernst, geochronology, 210; varves, 251

Apfel, E. T., analyses, 198, 201

Arey, M. F., Iowan boulders, 128, 130

Arkansas, Conard's Fissure, 187

Ash, volcanic, analysis of, 86 ; character of, 87-88; in Harrison County, 85-88; in Loveland formation, 85

\section{B}

Baker, C. L., cited, 61

Bemis moraine, 239

Benton County, Iowan drift in, 110, 112,115

Beyer, S. W., peat, 247

Black Hawk County, Iowan drift in 113,155 ; Iowan upland gravels in 142 ; pebble band in, 133

Boone County, moraine in, 240

Boulders, distribution of, 126; Illinoian, 15; Iowan, 125-130

Bremer County, Iowan boulders in, 128; pebble band in, 132, 133

Buchanan County, Buchanan gravels in, 111 ; Iowan boulders in, 128,129 ; Iowan drift in, 111-112, 115

Buchanan. interval, 154

Buena Vista County, moraine in, 238

Butler County, Iowan boulders in, 128

\section{C}

Calhoun County, Mankato gravels in, 218-219

Call, R. E., cited, 216

Calvin, Samuel, cited, 84; Iowan boulders, 128; Iowan drift, 92, 125, 154; loess origin, 157, 158
Cameron, Cornelia, cited, 60, 191; Peorian invertebrates, $167,170,189$ 190, 192-195

CErman, J. E., cited, 153; Iowan, 101, 117,145 ; Iowan gravels, 124, 152; northwest Iowa, 75, 78

Carrall County, Loveland sand and gravel in, 81; Mankato drift in, 215; moraine in, 238; Peorian loess in, 160

Cary glacial subage (substage), classification of, 13, 90, 156

Cass County, chemical analyses, 185 ; mechanical analyses, 185; Peorian loess, 185

"Cat-steps," 165

Cedar and Jackson areas, Peorian loess of, 163

Cedar County, Iowan drift in, 111, 155 ; pebble band in, 131, 132; Peorian loess in, 163

Cedar River, 42, 55, 57; Lake Calvin, 55 ; ponding of, 20

Centralian epoch (series), 15-88; classification of, 13,15

Cerro Gordo County, Mankato gravel in, 219 ; moraine in, 238

Chamberlin, T. C., cited, 238, 240, 241; classification, $89,92,203$

Cherokee County, Iowan drift in, 118121; Iowan upland gravels in, 145; Loveland loess fossils in, 62

Cherokee section, 118-119; Iowan upland gravel at, 145

Chickasaw County, Iowan boulders in, 127, 129; Iowan drift in, 111

"Citellus zone," 62, 188

Classification, of Aftonian, 13; of Cary, 13, 90, 156; of Centralian, 13, 15; of Eldoran, 13, 90, 156, 204, 244; of Grandian, 13; of Illinoian, 13,15 ; of Iowan, $13,90,156,204$; of Kansan, 13; of Mankato, 13, 90, 156, 204; of Nebraskán, 13; of Ottumwan, 13; of Peorian, 13, 90, 156, 204; of Pleistocene, 13; of Recent, 13, 90, 156, 244; of Sangamon, 13; of Tazewell, 13, 90, 156; of Wiscon- 
sin, 13, 89-90, 156, 203-204; of Yarmouth, 13

Clay County, Iowan drift in, 122; moraine in, 238

Clayton County, Iowan drift in, 111112

Climate, Peorian, 190; Sangamon, 52

Conard's Fissure, 187.

Concretions, 36, 138, 231

County-line exposure, 86-87

Crawford area, Peorian loess in, 161

Crawford County, Peorian loess in, 161-162

Cuthbert, F. L., cited, 186

D

Dallas County, Mankato drift in, 215, 217-218

DeGeer, G., geochronology, 210; varves, 251

Delaware County, Iowan drift in, 109

Des Moines County, Illinoian exposures in, 27; loess in, 28; Loveland mollusks in, 61

Des Moines lobe, 99, 203, 207, 240; moraines of, 239-242; peat on, 247

Des Moines River, 203, 207

Dewey, A. H., analysis, 38

Dickinson County, moraine in, $\mathbf{2 4 0}$

Drift sheets, distribution of, 16

Dubuque County, loess analyses, 253

$\mathbf{E}$

Eldoran epoch (series), 89-251; classification of, 13, 90, 156, 204, 244

Emmet County, Mankato gravel in, 233 ; moraine in, 240

\section{$\mathbf{F}$}

Farm Creek section, 52, 64, 157

Fauna, of Peorian, 189-190, 192-195; of Wisconsin age, 186

Fayette County, Iowan drift in, 109110,154 ; loess analysis from, 184, 253; Loveland loess in, 69-70; peb-. ble band in, 133

Flint, R. F., cited, 250

Floyd County; pebble band in, 134

Fossils, see vertebrates, invertebrates

Franklin County, moraine in, 238

Fremont County, Peorian fossils from, 164, 194
Frye, J. C., Lake Calvin, 58

\section{G}

Gary moraine, 241

Glacial map, 16

Grandian epoch (series), classification of, 15

Gravels, leaching of, 250

-, Illinoian, 17; lithological and mechanical analyses, 48 ; upland, 46

, Iowan terrace, characteristics of, 147-150; fossils in, 153; in Grundy County, 152; lithological analyses of, 151; mechanical analyses of, 149; map of, 146; in Mitchell County, 150; in Osceola County, 152 , Iowan upland, in Black Hawk County, 142; characteristics of, 141142 ; in Cherokee County, 145 ; lithological analyses, 144; map of, 140; mechanical analyses of, 143; in Mitchell County, 145

- _., Loveland, in Carroll County, 81 ; map, 80 ; in Lucas County, 84; in Page County, 84; in Plymouth County, 81; in Sac County, 79, 81

, Mankato terrace, 230; distribution map, 232; lithological analyses, 235; mechanical analyses, 234; sections, 231 - Mankato upland, 224; distribution map, 225; lithological analyses, 227; mechanical analyses, 226

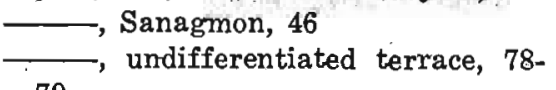
79

"Gray drift, young," 204

Greene County, Mankato drift in, 212, 242; Mankato gravel in, 233

Grundy County; Iowan boulders in, 130; lowan drift in, 115, 155; Iowan terrace gravels in, 152

"Gumbo," 91

Gumbosand, 23

Gumbotil zone, Illinoian, 31

Guthrie County, Mankato drift in, 215; moraine in, 238; Peorian loess in, 171-172

Gwynne, C. S., cited, 251; moraines, 243 


\section{$\mathbf{H}$}

Hamilton County, Mankato drift in, 218; moraine in, 238

Hancock County, moraine in, 238

Hardin County, Iowan drift in, 113114, 115; Mankato drift in, 215-216; Mankato gravel in, 228, 231; moraine in, 238

"Hardpan," 91

Harrison County, fossils in, 194 ; Loveland loess in, 67, 69; Loveland volcanic ash in, 85-88; Peorian loess in, 162, 164, 174

Henry County, Illinoian exposures in, 27; Peorian fossils in, 194

Hobbs, W. H., pebble band, 135

Howard County, Iowan boulders in, 127; Iowan drift in, 115

Humboldt County, Mankato in, 214

Humboldt moraine, 239

$$
\text { I }
$$

Illinoian glacial age (stage), $15-44$ classification of, 13,15

Illinoian 'drift, boundaries in Iowa, 19; discrimination 'of, 15; distribution of, 18, 19-20; in Des Moines County, 27; general character of, 20; in Henry County, 27; in Lee County, 29; in Louisa County, 26; in Muscatine County, 25; origin of, 20 ; in Scott County, 24 ; source of 20 ; weathering of, 21

Illinoian glacier, erosional work of, 20 ; source of, 15

Illinoian gravel, lithological analyses of, 48; mechanical analyses of, 48 ; Mad Creek, 17; weathered upland, 46

Illinoian gumbotil, analyses of, 33,34 ; -general description of, 31 ; lithological content of, 32 ; map of exposures, 37 ; shapes of grains of, 35 ; Sangamon age, 46; textule of, 32 ; thickness of, 35

Illinoian gumbotil plain, 46 ; dissection of, 59

Illinoian moraine, 19

Illinoian till, pebble analysis of, 38 ; source of, $42-43$; thickness of, 42 ; zones of weathering of, 22
Illinoian till, oxidized and leached zone, color of, 36 ; description of, 36 ; lithology of, 38; mechanical analysis of, 34 ; pebble analysis of, 38 ; shape analysis of, 38 ; texture of, 36,37 ; thickness of, 39

Illinoian till, oxidized and unleached, color of, $40^{*}$; description of, 39 ; lithology of, 40, 41; mechanical analysis of, 34; shape and size of grains of, 35 ; texture of, 40

Illinoran till, unoxidized and unleached zone, color of, 41 ; description of, 41 ; lithology of; 42 ; mechanical analysis of, 34 ; shapes of grains of, 42; texture of, 41

Illinois, Farm Creek section,. 52 ; gumbotil, 21; Sangamon peat, 53

Invertebrates, Loveland, 60-61; from Cherokee County, 60-61; from Des Moines County, 61 .

- Peorian, 167, 170; 189-190, 192-195; from Fremont County, 164; from Harrison County, 194; from Johnson County, 192-19:3; from Polk County, 194 ; Pottawattamie County, 194; southeastern Iowa, 193; Woodbury County, 195 . , Sangamon, 60-61

Iowa City, Peorian loess section near, 141; section near, 54

Iowan glacial subage (substage), 91155; classification of, $13,90,156$, 204

Iowan drift, boundaries in Iowa of, 19; distribution of, 100-10ó; castern area of, 103; history of interpretation of, $91-101$; lobes of, 102 ; margin of, 102; in northeastern Iowa, 107-117; in northwesterm Iowa, 117-125; origin of, 102 ; topography of, 101-104; western area of, $101-102,105$

Iowan terrace gravels, 147-153

Iowan till, boulders of, 125-130; discrimination of, 91 ; distribution of, 100-105; lithological analyses of, 182; oxidized and leached zone of, 135-138; oxidized and unleached zone of, $138-139$; pebble band of, 
130-135; thickness of, 153-155; weathering of, 107-108

Iowan upland gravels, 140-147

Iowa River, $19,42,51,55,166$; exposure on, 27 ; ponding of, 21 ; preIllinoian history of, 55

Iowa River valley, gumbotil in, 27; Lake Calvin, 55

\section{$\mathbf{J}$}

Jackson County, Peorian loess in, 163 James River lobe, 207

Johnson County, Iowan terrace gravels in, 148; loess analyses from, 253 ; loess fossils from, 192-193; Loveland loess in, 70, 72; Peorian loess in, 70, 166-170; Sangamon soil in, 54

\section{$\mathbf{K}$}

Kansan glacial age (stage), classification of, 13

-, gumbotil, map of exposures of, 37 ; northward extension of, 214 ; thickness of, 17

gumbotil plain dissection, 42 , 59, 77-78

, Kansan till, inliers of, 102;

lithological analyses of, 182 ; mineral analyses of, 74 ; in northwestern Iowa, 77-78

Kay, G. F., classification of, 13, 204; cited, $77,91,96,159$; duration of Recent, 248-249; Iowan till, 96; Loveland loess, 47, 49, 60, 63-64, pebble band, 130, 134

Kay, G. F. and Apfel, E. T., analyses, 35; cited, 103, 105, 212; Iowan, 103, 105, 109; loess topography, 160

Kay, G. F, and Cameron, Cornelia, invertebrates, 60

Kay, G. F. and Leighton, M. M., classification, $90,156,204,245$

Kay, G. F. and Miller, P. T., gravels, $79,141,147,224,230$

Keokuk County, Peorian loess in, 171

Keewatin Center, 20; Iowan drift from, 106; Mankato drift from, 204, 209; Wisconsin drift from, 89

Keyes, C. R., cited, 61, 211

\section{$\mathbf{L}$}

Labradorean center, 15, 20; Wisconsin drift from, 89

Lake Calvin, 19, 20, 45; area of, 55, 56 ; duration of, 58 ; origin of, 57

Lakes on Mankato drift, 206

Lane, G. H., pollens, 52

Lee County, Illinoian exposures in, 29,30 ; thickness in. 42-43; Illinoian drift in, 43

Lees, J. H., cited, 211, 216-217

Leighton, M. M., cited, 55; classification, 89, 204; Farm Creek section, 64; Iowa River, 55

Leighton, M. M., and MacClintock, Paul, cited, 21, 23

Leverett, Frank, channel, 57, 58; eited, $15,53,61,98,99,134,157,159$; classification, 89; Illinoian, 15; Illinoian topography, 59; Iowan, 93, 98, 99; loess, 47; moraines, 241; pebble band, 134; Sangamon, 45

Linn County, Iowan drift in, 116; loess analyses from, 253; pebble band in, 134

Loess, chemical analyses of, 184, 252255; correlations in Illinoian area, 47; distribution of, 160; in Des Moines County, 28; in eastern Iowa, 49 ; fossils, 167 ; general characteristics of, 172; Iowan drift, 116; invertebrates from, 189; leaching of, 195; lithological analyses of, 8284; see Loveland loess; mechanical analyses of, 168, 173-181; on Mankato, 295; origin of, 157 ; relation of pebble band to, 134; Peorian, 157 ; of Sangamon, late, 47; sections of, 166-172; source of, 165 , 181; Tazewell, 157; thickness of, $196,197,199$; vertebrates from, $180-189$

Louisa County, elephant bones from, 62; Illinoian exposures in, 26; Sangamon peat in, 51; Sangamon soil in, 54 ; thickness of Illinoian, 43

Loveland formation, age of, 49-50; deposits of, 63-64; loess of, 64-75; origin of, 63 ; sands and gravels of, $75-85$; type section of, $63-65$; vol- 
canic ash of, $85-88$

Loveland loess, age of, 49-50; comparison with Peorian, 198; concretions in, 66; in Fayette County, 6970 ; fossils of, 60, 194; in Harrison County, 67, 69; lithological analyses of, 182, 201-202; mechanical analyses of, 72-73, 201-202; mineral analyses of, 72-75; in Montgomery County, 65; in northeast Iowa, 64, 69 ; in O'Brien County, 67, 69; in Plymouth County, 66 ; in Pottawattamie County, 65, 66; relationships of, $49,50,65$; sample locations map of, 71 ; in Shelby County, 68, 69; thickness, 203; in western Iowa, $65-69$

Loveland sand and gravel, agè of, 75; in Carroll County, 81; character of, 79 ; chemical analyses of, 82 ; distribution of, 75 ; in Lucas County, 84; maps, 76; mechanical analyses of, 82; in northwestern Iowa, 79; in Page 'County', 84; pebble lithology of, 83; in Plymouth County, 81 ; in Sac County, 79, 81; source of, 75 ; in southern Iowa, 84

Lucas County, Loveland sand and gravel in, 84

Lugn, A. L., ash, 85 ; cited, 62

Lyon County, Iowan drift in, 124

Lyell, Charles, cited, 244

\section{M}

McGee, W J, cited, 91, 128, 157, 187, 216 ; loess origin, 157 ; musk ox, 187188

Mad Creek, Illinoian gravel, 17

Mammal remains from, Louisa County, 62; Mills County, 188; Muscatine County, 61; Pottawattamie County, 187, 188; Scott County, 62

Mankato glacial subage, 203-245; classification of, 13, 90, 156, 204

Mankato drift, changes in, 210,248 ; Des Moines lobe of, 203; discrimination of, 205-206; distribution of, 206-209; leaching of, 246; morainic complex of, 237; origin of, 209; peat on, .246; sections of, 211; source of, 204
Mankato morainic complex, 237; morainal map of, 239; Des Moines lobe, 203

Mankato terrace gravels, distribution map of, 232; lithological analyses of, 235; mechanical analyses of, 234 ; sections of, 231

Mankato till, lithological analyses of, 182,222 ; oxidized and leached zone of, 220-221; unoxidized and unleached zone of, 223

Mankato upland gravels, 224; distribution map of, 225 ; lithological analyses of; 227; mechanical analyses of, 226 ; sections of, $228-230$; thickness of, 242

Marshall County, chemical analyses from, 185; Mankato drift in, 212, 213; mechanical analyses from, 185

Mesotil, 21

Millex, P. T., analyses, 198, 201

Mills County, invertebrates from, 194; mammals, 188; Peorian loess in; 164

Mineral ridge, 241

Minnesota, 238, 241

Missouri River valley, $165,166,181$

Mitchell County, Iowan drift in, 116; Iowan terrace gravels in, 150; Iowan upland gravels in, 145

Mitchellville cut, 169, 209

Monona County, Peorian loess in, 164

Montgomery County, Loveland loess in, 65

Moraines, Altamont, 239, 241, 242; Bemis, 239, 241-242; distribution of, 239; Gary, 241, Gwynne on, 243; Humboldt, 239; Mankato, 205, 237242, 239; Ruthven, 229

Muscatine County, Illinoian exposures in, 25; elephant remains from, 61

\section{$\mathbf{N}$}

Nebraska, Citellus zone in, 188; fossils from Loveland loess in, 62; Loveland formation in, 85; Peorian loess in, 187; vertebrates from, 188; volcanic ash in, 85

Nebraskan glacial age (stage), classification of, 13; Nebraskan drift, 15; Nebraskan gumbotil thickness, 17; 
till, mechanical analyses of, 34

New London, Illinoian drift near, 29 North Liberty lobe, 166; fossils from, 193; sections of, 192

Norton, W. H., boulders, 128; Cedar River, 57

\section{O}

O'Brien County, Iowan drift in, 122 , 123; Loveland loess in, 67, 69

Ocheyedan Mound, 240

Oelwein section, 109

Osceola County, Iowan drift in, 123124; Iowan terrace gravels in, 152

Ottumwan epoch (series), classification of, 13

Outwash, Mankato, 209

Oxidized and leached zone, mechanical analyses of, 34 ; of Iowan till, 135; color of, 136; pebble analyses of, 137 ; texture of, 136; of Illinoian till, 36 ; of Kansan till, pebble analyses of, 137

oxidized and unleached zone, mechanical analyses of, 34

of Iowan till, 138; concretions in, 38; pebble lithology of, 137, 138; texture of, 138; of Illinoian till, 39; of Kansan till, pebble analyses of, 137

\section{$\mathbf{P}$}

Page County, Loveland sand and gravel in, 84

Paleontology, see vertebrates, invertebrates

Palo Alto County, Mankato gravel in, 229-230

Patrician center, 89; Mankato drift from, 204

Peat, 45; in Louisa County, 51

- on Mankato drift, 207, 246; character of, 247; location of, 249 ; origin of, 245

- Sangamon, 50, 52

Pebble band, Iowan, 130; in Black. Hawk County, 133; in Bremer County, 132-134; in Cedar County, 131; in Fayette County, 133; in Floyd County, 134; in Linn County, 134; origin of, 134-135; in Worth County, 132
Peorian intraglacial subage (substage), 155-203; classification, 13, $90,156,204$; climate of, 190

Péorian loess, 157 ; in Cedar and Jackson areas, 163; chemical analyses of, 18, 253-254; comparison with Loveland, 198; in Crawford area, 161 ; depth of leaching in, 195; distribution of, 160 ; fossils in, 167, 171,186 ; general characteristics of, 172 ; in Guthrie County, 171 ; invertebrates from, 189; in Johnson County, 166-169; in Keokuk County, 171; mechanical analyses of, 173 181 ; mineralogical analyses of, 182 184, 201-202; in Polk County, 169171; in Scott County, 171; source of, 165, 181; thickness of, 196-197, 199, 203; loess-mantled topography of, 160; loess-depositional topography of, 164; vertebrates from, 26-29

Pleistocene system, classification, in Iowa, 13; in Mississippi Valley, 13

Plymouth County, Loveland loess in, 66 ; sand and gravel in, 81

Pocahontas County, Mankato drift in, 219

Polk County, Mankato drift in, 211, 217; Mitchellville cut in, 209; moraine in, 238; Peorian fossils, 194

Pollen, profiles, 248; from Sangamon peat, 52 ; Lane, G. H., 52 ; Sears, P. B., 248

Pottawattamie County, invertebrates from, 194; Loveland loess in, 65-66; Peorian loess in, 164; Peorian mammals from, 187-188

Pratt, W. H., cited, 53

\section{$\mathbf{R}$}

Recent interglacial age (stage), 245251 ; classification of, $13,90,156$, 244; duration of, 248; leached Mankato of, 246; peat on Mankato, 246

"Red drift, young," 204

Ruthven moraine, 229

\section{$\mathbf{S}$}

Sac County, Iowan drift in, 121-122;

Loveland sand and gravel in, 79, 81; Mankato in, 216; moraine in, 238 
Sands, Illinoian, 17; Loveland, 75; Sangamon, 46; undifferentiated, 78 ; see gravels

Sangamon interglacial age (stage), 45-88; classification of, 13 ; climate of, 52,62 ; erosion in, 58 ; features of, 46 ; invertebrates from, 60-61; loess, late, of, 47 ; peat of, 50-53; pollen of, 52 ; record of life in, 60 62 ; sands and gravels of, 46 ; soils of, 53-54; terminology of, 45 ; vertebrates from, 61-62; weathered zones of, 46

Sangamon soils, in Johnson County, 54; in Louisa County, 54; in Scott County, 53

Savage, T. E., boulders, 138

Schultz, C. B., vertebrates, 189

Schoewe, W. H., Lake Calvin, 19, 58

Scott County, elephant remains from, 62 ; Illinoian exposures in, 24 ; Loveland peat in, 53; Loveland sections in, 50; Loveland soil in, 53; Peorian loess in, 171; Peorian fossils from, 193; Sangamon soil in, 53

Sears, P. B., pollen, 248

Shelby County; Loveland loess, 68, 69

Shelbyville till, 157

Shimek, Bohumil, gastropods, 191; Ioess origin, 158; Loveland, 63; mammals, 188

Silttil, 21

Skunk River, 19, 42

Smith, J. E., moraines, 242

Soil, Loveland, 188 ; Peorian, 187; profiles, 23, 55; zones, 244

South Dakota, 241; volcanic ash in; 85

Story County, moraine in, 238

\section{$\mathbf{T}$}

Tazewell glacial subage (substage), classification, $13,90,156$; drift sheet, 159; loess, 157

Tester, A. C., volcanic ash, 87

Thwaites, F. T., Mankato classification, 204

Tree rings, 244

Trowbridge, A. C., Lake Calvin, 58 $\mathbf{U}$

Udden, J. A., cited, 61, 62 ; vertebrates, 188
Upham, Warren, 238

Uplift of Loveland age, 75, 77-78

Upper till, 157

Undifferentiated terrace gravels, 78; map of, 80

Unoxidized and unleached zone, mechanical analyses of, 34; Illinoian till, 41; Iowan drift, 112-113, 139

\section{$\mathbf{V}$}

Varves, 251

Vertebrates, scarcity of remains, 186 , Peorian; 186-189

, Sangamon, 61-62

Volcanic ash, character of, 87-88; in Harrison County, 85-88; in Loveland formation, 85 ; mechanical analyses of, 86

\section{$\mathbf{W}$}

Wapsipinicon River, 24, 42 ; Iowan terrace gravel, 150

Webster County, Mankato in, 214

West Point, Illinoian drift near, 30; terminal moraine at, 19

West Union cut, 182-183

White, C. A., Mankato moraine, 237238

Williams, A. J., Lake Calvin, 58

Williams, I. A., boulders, 127

Winnebago County, moraine in, 238

Wisconsin glacial age (stage), 89243 ; classification of, 13, 89-90, 156, 203, 204; vertebrate fauna from, 186; Iowan subage (substage) 91155; Mankato subage, 203-245; Peorian subage, 155-203

Woodbury County, Peorian fossils in, 194; Peorian loess in, 164

Worth County, boulders in, 127; Iowan drift in, 110, 114, 115; pebble band in, 132; Mankato gravels in, 219,228 ; moraine in, 238

Worthen, A. H., cited, 45

Wright County, Mankato drift in, 219

$\mathbf{Y}$

Yarmouth, classification of, 13

Z

Zones of weathering, 22, 23 